UNIVERSIDADE DE SÃO PAULO

FACULDADE DE FILOSOFIA, LETRAS E CIÊNCIAS HUMANAS DEPARTAMENTO DE LÍNGUAS MODERNAS

PROGRAMA DE PÓS-GRADUAÇÃO EM ESTUDOS DA TRADUÇÃO

ALESSANDRA OTERO GOEDERT

TRADUÇÃO JURAMENTADA E AS MODALIDADES DE TRADUÇÃO: O CASO DOS HISTÓRICOS ESCOLARES

SÃo PAULO

2015 
UNIVERSIDADE DE SÃO PAULO

FACULDADE DE FILOSOFIA, LETRAS E CIÊNCIAS HUMANAS

DEPARTAMENTO DE LÍNGUAS MODERNAS

PROGRAMA DE PÓS-GRADUAÇÃO EM ESTUDOS DA TRADUÇÃO

TRADUÇÃO JURAMENTADA E AS MODALIDADES DE TRADUÇÃO:

O CASO DOS HISTÓRICOS ESCOLARES

\section{Alessandra Otero Goedert}

Dissertação apresentada ao Programa de Pós-Graduação em Estudos da Tradução do Departamento de Letras Modernas da Faculdade de Filosofia, Letras e Ciências Humanas da Universidade de São Paulo, para a obtenção do título de Mestre em Estudos da Tradução.

Orientador - Profa. Dra. Adriana Zavaglia

v.1

SÃo PAULO

2015 
Dedico este trabalho ao Prof. Dr. Francis Henrik Aubert, inspirador e contagiante por sua paixão pelo ofício e pela academia 
Autorizo a reprodução e divulgação total ou parcial deste trabalho, por qualquer meio convencional ou eletrônico, para fins de estudo e pesquisa, desde que citada a fonte.

Catalogação na Publicação

Serviço de Biblioteca e Documentação

Faculdade de Filosofia, Letras e Ciências Humanas da Universidade de São Paulo

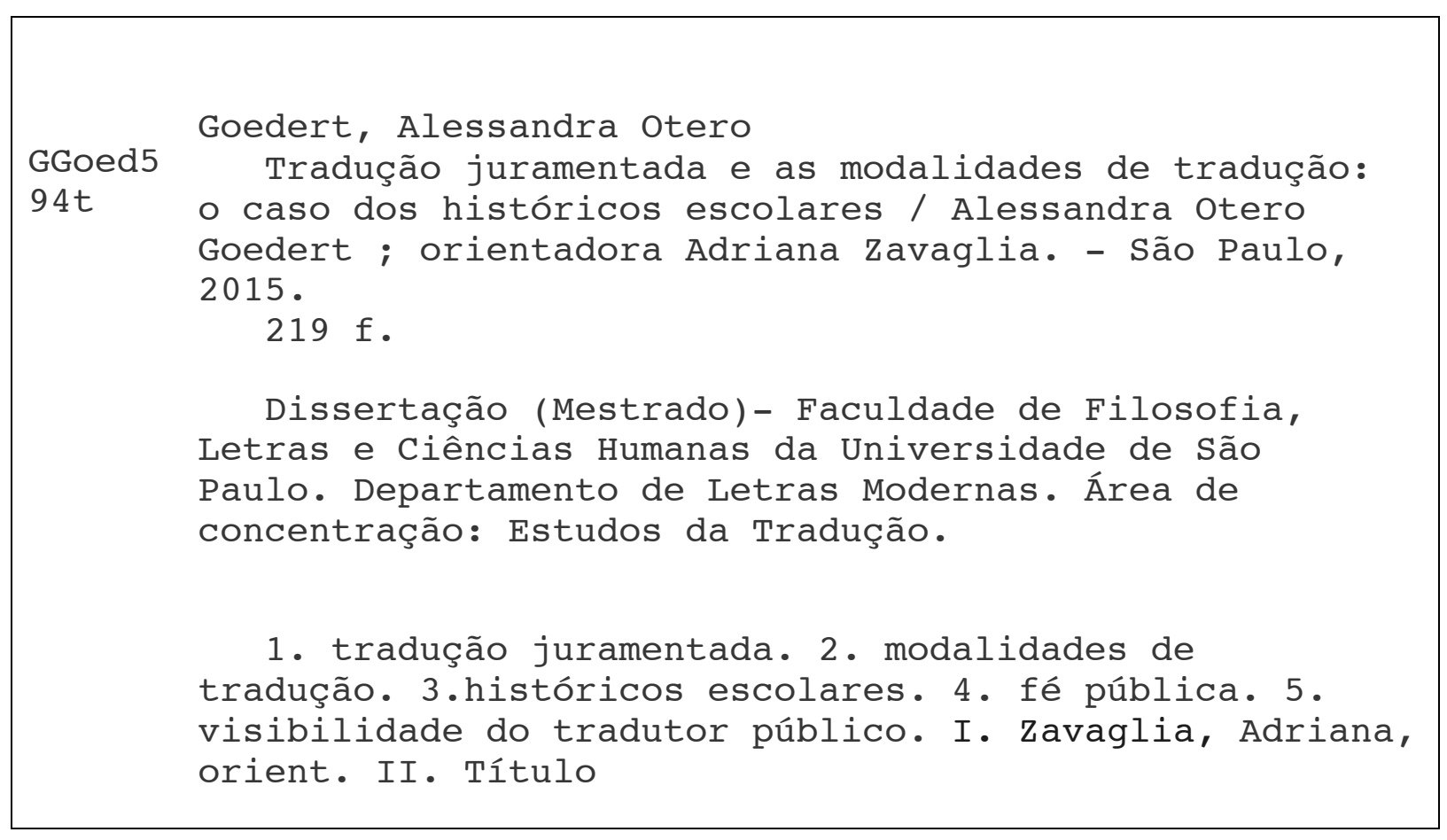


GOEDERT, Alessandra Otero

Tradução juramentada e as modalidades de tradução: o caso dos históricos escolares.

Dissertação apresentada ao Programa de PósGraduação em Estudos da Tradução do Departamento de Letras Modernas da Faculdade de Filosofia, Letras e Ciências Humanas da Universidade de São Paulo para a obtenção do título de Mestre em Estudos da Tradução.

Área de concentração: Tradução e Corpora

Aprovado em:

Banca Examinadora

Prof. Dr. Instituição:

Julgamento: Assinatura:

Prof. Dr. Instituição:

Julgamento: Assinatura:

Prof. Dr. Instituição:

Julgamento: Assinatura: 


\section{AGRADECIMENTOS}

Ao Prof. Dr. Francis Henrik Aubert, por ter acreditado em meu esforço e competência para participar no Programa de Pós-Graduação em Estudos da Tradução e colaborar com sua linha de pesquisa.

À Prof. Dra. Adriana Zavaglia, por ter me acolhido e colaborado de forma inestimável na conclusão desta dissertação.

À Prof. Dra. Diva Cardoso de Camargo e ao Prof. Dr. João Azenha Jr. pelas valiosas contribuições dadas em ocasião do Exame de Qualificação.

À minha mãe, Rosa Maria, por ter sempre exigido o melhor de mim, fato que contribuiu muito na minha formação como profissional dedicada e detalhista.

À minha filha, Giovanna, pelo apoio e compreensão das minhas ausências, seu carinho e admiração sempre estimulantes.

Aos meus avós, Daisson e Rosinha, in memoriam, por terem me proporcionado o estudo da língua inglesa em tempos em que não era tão acessível como nos dias de hoje. Minha carreira é fruto da visão, constante apoio e investimento deles.

À minha tia Therezinha Cecília, por seu incentivo e ajuda na busca pelo texto de partida, apresentando-me à Vivian Orosco.

À Vivian Orosco, por ter me cedido e autorizado o uso de seu histórico e, além disso, ter atuado como cliente na solicitação das doze traduções juramentadas.

A Emerson Viana, inestimável amigo, arrojado empreendedor e parceiro profissional, por sua generosidade e compreensão nos momentos em que me dediquei a esta pesquisa, além da enorme contribuição por meio de nossas conversas e discussão acerca da prática tradutória.

A Fernando Mariani, primo querido, grande amigo, profissional de destaque na área de tradução, por sua contribuição e comentários perspicazes na análise das traduções.

A Paulo Morais, amigo e parceiro tecnológico, pelo esmero na realização do Design Gráfico da dissertação.

Aos tradutores que, mesmo sem terem o conhecimento deste trabalho, contribuíram para o desenvolvimento da pesquisa.

Ao corpo docente do Programa de Pós-Graduação em Estudos da Tradução, difusores do conhecimento, grandes incentivadores e relevante inspiração para o desenvolvimento deste trabalho.

À Edite e Junior, funcionários do Departamento de Letras Modernas da FFCLH, sempre muito solícitos no esclarecimento de dúvidas, informando prazos e fornecendo os materiais de apoio burocrático essenciais para o bom andamento da pesquisa e,

Aos meus queridos amigos de longa data e tradutores profissionais, Rita Miriam Zagordo, Ana Nakano, André Luiz Izzo Kaplar, Joel Lira e Eduardo Montovani que, direta ou 
indiretamente me apoiaram e alegraram nas poucas horas de descanso; e colegas e novos amigos do Tradusp, que partilharam as angústias, dúvidas, incentivaram a caminhada e participaram nos diversos congressos e comunicações, ouvindo atentamente e de forma crítica minhas apresentações. 
A tradução juramentada é como se fosse (ou pretendesse ser) uma transparência sobre o original, servisse como um guia de leitura do original, relatando o que consta do original - e não o [que] "deveria" ter constado. 


\section{RESUMO}

GOEDERT, Alessandra Otero. Tradução Juramentada e as Modalidades de Tradução: o caso dos históricos escolares. 2015. (219)f. Dissertação (Mestrado em Estudos da Tradução) Faculdade de Filosofia, Letras e Ciências Humanas, Universidade de São Paulo, São Paulo, 2015.

Esta dissertação trata da temática da tradução juramentada, que tem sido cada vez mais objeto de pesquisa nos Estudos da Tradução, por conta de sua presença significativa, seja no âmbito acadêmico ou empresarial. A tradução juramentada, que difere das demais formas de tradução especialmente pela força imposta pela fé pública, que incide na postura e olhar adotados pelos Tradutores Públicos e Intérpretes Comerciais brasileiros, nos conduziu à hipótese de que a visibilidade do tradutor torna-se acentuada em virtude da delegação desse poder, que tem por finalidade principal a segurança jurídica das relações negociais na sociedade. A partir de um histórico escolar brasileiro do Ensino Médio, traduzido por doze tradutores públicos paulistanos para o inglês do Canadá, este trabalho tem por objetivo, com o auxílio das modalidades de tradução de Aubert (2006), mapear as estratégias de tradução e os perfis desses diferentes profissionais, oriundos de duas gerações distintas, aprovados nos dois últimos concursos realizados pela Junta Comercial do Estado de São Paulo (1978 e 1998), considerando a sua visibilidade pela fé pública. A tipologia textual documento escolar e o gênero histórico escolar foram selecionados tendo em vista sua grande frequência em tradução juramentada, motivada pelo crescente intercâmbio acadêmico-cultural entre Brasil, Canadá, Estados Unidos e demais países de língua inglesa. Para tanto, realizamos uma breve reflexão acerca dos modelos de Berman (1985), Reiß $(1971,1976)$ e Baker (1996) e suas respectivas aplicações no tocante à tradução juramentada e, particularmente, ao estudo do objeto de pesquisa em pauta. Em seguida, descrevemos os procedimentos técnicos de tradução de Vinay e Darbelnet (1958), que serviram como base para a concepção do modelo das modalidades de tradução de Aubert (1984, 1998, 2006). Complementarmente, retratamos a evolução do modelo das modalidades de tradução, com destaque para as mudanças ocorridas e possíveis contribuições. Para tanto, adotamos no presente estudo uma metodologia com base em duas etapas. Primeiramente, realizamos o levantamento dos dados em relação às dispersões das soluções tradutórias e, em seguida, classificamos os dados em unidades lexicais para aplicação do modelo das modalidades de tradução. Por fim, descrevemos o perfil de cada tradutor e os resultados gerais por grupo, bem como o comparativo das duas gerações, 
com o auxílio de gráficos. A hipótese da visibilidade acentuada mostrou-se válida e necessária como garantia jurídica da boa aplicação da fé pública no cumprimento do ofício do tradutor público e intérprete comercial.

Palavras-chave: tradução juramentada, modalidades de tradução, históricos escolares, fé pública, visibilidade do tradutor público. 


\begin{abstract}
GOEDERT, Alessandra Otero. Sworn Translation and Translation Modalities: the case of school transcripts. 2015. (219)f. Dissertação (Mestrado em Estudos da Tradução) - Faculdade de Filosofia, Letras e Ciências Humanas, Universidade de São Paulo, São Paulo, 2015.
\end{abstract}

This dissertation addresses the topic of sworn translation, which has been increasingly researched in the field of Translation Studies by virtue of its relevant presence, whether in the academic or corporate areas. Sworn translation, which differs from other kinds of translations particularly for the power vested by the full faith and credit, having an effect on the attitude and view adopted by Brazilian Sworn Translators and Commercial Interpreters, led us to the hypothesis that the translator's visibility is emphasized by the vesting of such power, the main purpose of which is to ensure legal certainty in business relations in society. From a Brazilian secondary school transcript translated by twelve sworn translators of the State of São Paulo into Canadian English, this work aims, with the support of Aubert's translation modalities (2006), to map the translation strategies and profiles of such various professionals, from two different generations, who passed the last two public examinations held by the Board of Trade of the State of São Paulo (in 1978 and 1998), taking into account their visibility by the full faith and credit. The text typology 'school document' and the gender 'school transcript' were chosen because of their great frequency in sworn translation, motivated by the increasing academic and cultural exchange between Brazil and Canada, the United States, and other English-speaking countries. Therefore, we briefly reflected on Berman (1985), Rei $\beta$ (1971, 1976) and Baker's (1996) models and their application to sworn translation and particularly to the study of the subject matter hereof. Then, we described Vinay and Darbelnet's (1958) translation procedures, which were the basis for the conception of Aubert's (1984, 1998, 2006) translation modalities model. In addition, we outlined the evolution of the translation modalities model, with an emphasis on changes made and possible contributions. Thus, we adopted a two-stage methodology in this study. First, we compiled the data for the dispersion of the translation solutions, and then, classified the data into lexical units to apply the translation modalities model. Finally, we described the profile of each translator and the general results by group, as well as a comparison between the two generations, presented in graphical form. The hypothesis of high visibility was proven to be valid and necessary as a 
legal guarantee of the proper application of full faith and credit in fulfilling the office of sworn translator and commercial interpreter.

Keywords: sworn translation, translation modalities, school transcripts, full faith and credit, sworn translator's visibility. 


\section{LISTA DE QUADROS, FIGURAS E TABELAS}

\section{Quadros do Capítulo 2}

Quadro 2.1.1 - Relação das Juntas Comerciais

Quadro 2.1.2 - Tabela de Emolumentos - Valores para Tradução de Língua Estrangeira para

Vernáculo

Quadro 2.1.3 - Legislação Vigente

Figura do Capítulo 2

Figura 2.2.1: Legalização do Departamento de Estado dos Estados Unidos da América

\section{Quadros do Capítulo 3}

Quadro 3.1.1 - Classificação geral para os tipos de texto (cf. Azenha,1999:45)

Quadro 3.1.2 - Características funcionais dos tipos de texto (tradução nossa) ....................... 49

Quadro 3.1.3 - Variedades e tipos de texto segundo o modelo de Reiß (1971) ...................... 51

Quadro 3.2.1 - Evolução do modelo das modalidades de tradução de Aubert $(1998,2006)$.. 67

\section{Figura do Capítulo 3}

Figura 3.2.1: Verso de certidão de casamento

\section{Tabela do Capítulo 4}

Tabela 4.2.1 - Modelo da tabela para apresentação dos dados estatísticos, segundo as modalidades de tradução (intitulada: Distribuição das Modalidades de Tradução para Tradutores Habilitados em (ano)).

Tabelas do Capítulo 5

Tabela 5.1 - Distribuição das Modalidades de Tradução para Tradutores Habilitados em 1978

Tabela 5.2 - Distribuição das Modalidades de Tradução para Tradutores Habilitados em 1998

\section{Gráficos do Capítulo 5}

Gráfico 5.2.1 - Distribuição das Modalidades de Tradução para Tradutores Habilitados em 1978 .

Gráfico 5.2.2 - Distribuição das Modalidades de Tradução para Tradutores Habilitados em 1998. 


\section{SUMÁRIO}

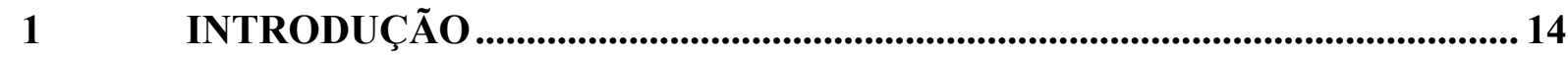

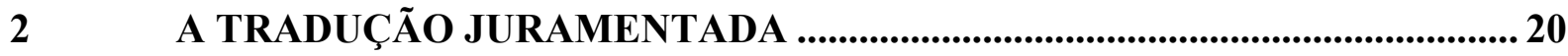

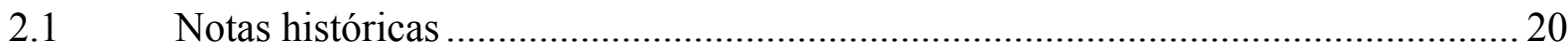

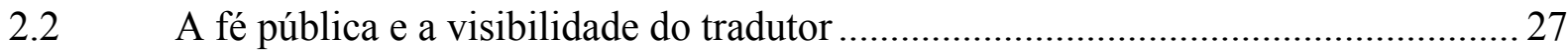

3 FUNDAMENTAÇÃO TEÓRICA .............................................................42

3.1 Reflexões sobre os Modelos Teóricos de Berman, Reiß e Baker .............................. 42

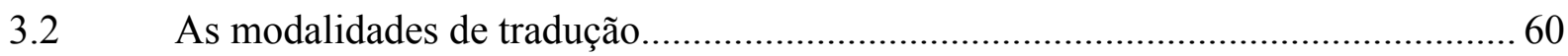

4 MATERIAL DE ESTUDO E METODOLOGIA ............................................. 81

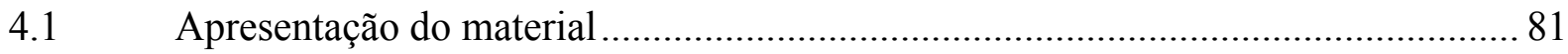

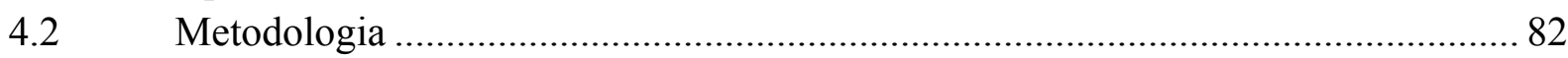

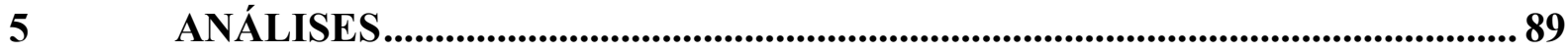

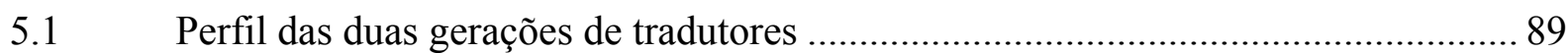

5.1.1 Ficha descritiva do perfil do Tradutor 1 - Grupo de 1978_....................................... 96

5.1.2 Ficha descritiva do perfil do Tradutor 2 - Grupo de 1978_...................................... 99

5.1.3 Ficha descritiva do perfil do Tradutor 3 - Grupo de 1978_................................... 103

5.1.4 Ficha descritiva do perfil do Tradutor 4 - Grupo de 1978...................................... 107

5.1.5 Ficha descritiva do perfil do Tradutor 5 - Grupo de 1978 ………......................... 110

5.1.6 Ficha descritiva do perfil do Tradutor 6 - Grupo de 1978..................................... 114

5.1.7 Ficha descritiva do perfil do Tradutor 7 - Grupo de 1998_................................... 118

5.1.8 Ficha descritiva do perfil do Tradutor 8 - Grupo de 1998_................................... 122

5.1.9 Ficha descritiva do perfil do Tradutor 9 - Grupo de 1998....................................... 126

5.1.10 Ficha descritiva do perfil do Tradutor 10 - Grupo de 1998...................................... 129

5.1.11 Ficha descritiva do perfil do Tradutor 11 - Grupo de 1998 ………....................... 133

5.1.12 Ficha descritiva do perfil do Tradutor 12 - Grupo de 1998.................................. 137

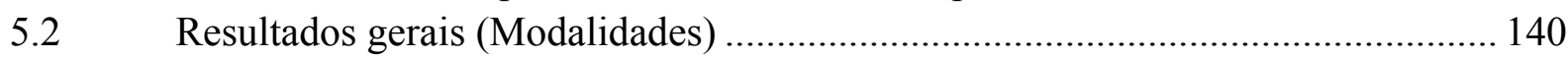

5.3 Contribuições para o modelo das modalidades ........................................................ 152

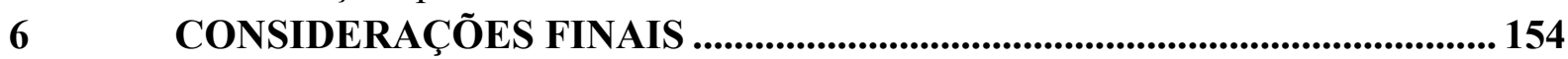

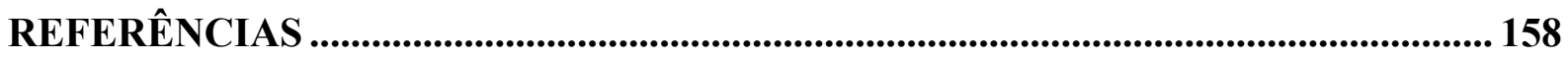

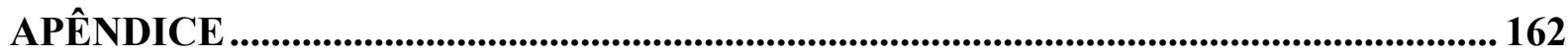

ANEXO A - Texto de partida .............................................................................................. 210

ANEXO B - Junta Comercial do Estado de Minas Gerais - Anexo I da Resolução

RP/07/2012 de 18 de outubro de 2012 ................................................................... 212 


\section{INTRODUÇÃO}

A Área da Tradução Juramentada despertou meu interesse muito antes de minha nomeação como Tradutora Pública e Intérprete Comercial no Estado de São Paulo. Na época de minha graduação na Universidade Anhembi Morumbi em Letras com habilitação em tradução e interpretação, utilizamos uma apostila elaborada pelo Prof. Dr. Francis Henrik Aubert, intitulada "Tipologia e Procedimentos da Tradução Juramentada I" publicada pelo CITRAT (Centro Interdepartamental de Tradução e Terminologia) da FFLCH, Universidade de São Paulo, por meio da qual me familiarizei com a área. Nessa mesma ocasião, tomei conhecimento das modalidades de tradução de Aubert (1984, 1998, 2006) por vários exercícios realizados nas aulas de análise contrastiva de tradução. O propósito desses exercícios era o de observar o que ocorria durante o processo tradutório, mediante a comparação entre a solução de tradução apresentada e o texto original.

Com o decorrer do tempo, paralelamente à minha atuação no mercado de traduções, surgiu a necessidade de estar em contato com o meio acadêmico, para aprimorar minha prática profissional. Essa necessidade, atrelada à carência de estudos na área, levaram-me a realizar esta pesquisa, no intuito de contribuir para o estudo da tradução juramentada e aumentar a interação entre academia e mercado.

Nesse sentido, ao pensarmos no mercado de trabalho e na tarefa de tradução, e imaginarmos duas situações em épocas distintas, podemos observar que houve grandes mudanças na atuação do tradutor. Num passado não muito distante, por volta dos anos oitenta, o modo de trabalho de um tradutor envolveria o uso de uma máquina de escrever e um facsímile, equipamentos que atualmente se tornaram obsoletos. A capacidade produtiva desse profissional estava condicionada à limitação dessas máquinas. Por exemplo, qualquer alteração ou correção no texto implicaria, em muitos casos, datilografar novamente toda a página em questão. Além disso, a pesquisa para buscar equivalentes era, em geral, realizada por consulta aos dicionários de posse do tradutor e, quando o termo não era encontrado em sua "biblioteca particular", ele provavelmente teria que recorrer às bibliotecas públicas, fato que significava um deslocamento até o local. Dependendo da distância de sua casa ou escritório até a biblioteca, essa necessidade de deslocamento tomaria grande parte de seu dia, o que reduzia sua capacidade de produção. O recebimento e envio de documentos era feito 
pessoalmente, por fac-símile ou por correio e, nesse último caso, dependendo da distância, poderia levar semanas ou até meses.

Em contrapartida, se compararmos com a atividade prática de um tradutor do final dos anos noventa até os dias de hoje, o computador ou notebook tornou-se a ferramenta principal de trabalho, em suas diversas configurações. A rapidez e agilidade adquiridas com esses equipamentos modificaram a rotina desse profissional, em especial, sua capacidade de produção e a possibilidade de armazenagem de dados. Tarefas como corrigir ou alterar palavras, antes limitadas, passaram a ser imediatas e simples, com o uso de teclas para apagar, inclusive para substituir uma palavra por outra ou substituir uma palavra em todo o texto. A economia de tempo obtida foi excepcional, além da diminuição nos gastos com material de trabalho. Em termos de pesquisa, a internet revolucionou não apenas essa questão fundamental na prática tradutória, como também a comunicação. $\mathrm{O}$ tradutor possui acesso, em tempo real, a dezenas de milhares de sites de instituições, empresas públicas e privadas, órgãos governamentais, inclusive, com a possibilidade de visualizar e confirmar dados sobre a universidade ou empresa, por exemplo, que seja mencionada no documento a ser traduzido. A oportunidade de verificação dessas informações nas próprias fontes aumentou o grau de confiabilidade de suas escolhas e soluções tradutórias. Por outro lado, em alguns casos, pode gerar dependência tradutória. No tocante à comunicação, o surgimento do e-mail permitiu o recebimento e envio imediato de documentos. Há ainda, muitos outros recursos (memórias de tradução, armazenagem nas nuvens, programas de reconhecimento de voz), como o acesso remoto que permite ao tradutor acessar de sua residência o banco de dados de um escritório para o qual trabalhe, por exemplo, para a consulta de glossários específicos por área ou por cliente. Portanto, é certo que essas tecnologias proporcionaram muitos benefícios e, ao mesmo tempo, geraram novas exigências do mercado, quanto a prazo e qualidade dos serviços prestados. Ademais, alteraram significativamente a dinâmica desse mercado e, por conseguinte, a metodologia de trabalho do tradutor.

Logo, ao fazermos esses breves comentários históricos, notamos que o perfil do profissional, antes mais solitário e isolado, mudou para mais dinâmico e interativo numa nova ordem tecnológica e de mercado. A interação provocada pelos diversos gadgets, aplicativos e chats, que o colocaram em contato com o mundo, muito provavelmente causou essa reconfiguração em seu perfil, proporcionou maior dinamismo nas etapas de produção e mais assertividade nas soluções de tradução encontradas. 
Ainda assim, nessa realidade, há uma categoria de tradutor que difere dos demais, em virtude da delegação da fé pública obtida mediante aprovação em concurso público, realizado pelas juntas comerciais dos respectivos estados no Brasil, a saber, o tradutor público e intérprete comercial. A fé pública é o componente que define e distingue a tradução juramentada das demais. Por tradução juramentada entende-se:

a tradução oficial, feita por tradutor público (comumente conhecido como tradutor juramentado), exigida legalmente em todo o território nacional para que documentos redigidos em língua estrangeira produzam efeito em repartições da União, dos Estados ou dos Municípios, em qualquer instância, juízo ou tribunal ou entidades mantidas, fiscalizadas ou orientadas pelos poderes públicos (artigo 157 do Código de Processo Civil e Decreto Federal $\mathrm{n}^{\mathrm{o}} 13.609$ de 21.10.1943). ${ }^{1}$

Essa definição, segundo Aubert (2005:247) "pressupõe uma invariança semântica e discursiva entre o texto da tradução juramentada e seu original." Ou seja, espera-se uma tradução com foco maior no texto de partida, por conta dos efeitos que venha a produzir, e por se tornar um instrumento legal com livre circulação nos órgãos públicos e tribunais.

Todavia, o tradutor público aprovado em concurso não é nomeado para nenhuma área específica do conhecimento. Sua atuação está sujeita a toda a sorte de documentos, conforme estabelece o artigo 6 da Deliberação Jucesp n⿳0 04, que rege o ofício: "O tradutor público e intérprete comercial não poderão (sic) recusar-se a fazer tradução ou versão de texto no idioma em que esteja legalmente habilitado."2 O fato de não poder recusar os trabalhos implica a obrigação de disponibilidade para realizar a tradução ou versão de qualquer tipologia textual, ou seja, da área jurídica, acadêmica, médica, financeira, dentre outras, nos quais estão presentes fortes marcas culturais inerentes ao idioma de partida.

Logo, existe um conflito entre essa exigência legal de transparência, ao ter que, em tese, dizer tudo o que contém o original, nada além do original, e as marcas culturais presentes nos referidos textos submetidos a esse tipo de tradução, que tendem a exigir uma abordagem comunicativa. Aubert (2005:248, grifos nossos) salienta essa divergência ao comentar que:

Seria de se esperar que uma tradução com tal propósito adotasse uma postura mais marcadamente tendente à literalidade: [...]. Resultaria, assim,

\footnotetext{
${ }^{1}$ Definição extraída do site da Associação dos Tradutores Públicos e Intérpretes Comerciais de São Paulo: www.atpiesp.org.br/associacao/traducao-juramentada

${ }^{2}$ Disponível em: www.institucional.jucesp.sp.gov.br/downloads/Deliberacao_Jucesp_04_de_01.11.pdf
} 
em soluções de tradução direta mais do que de tradução oblíqua (Vinay \& Darbelnet, 1958, 1977), em traduções literais, transposições e explicitações mais do que de modulações ou adaptações (Aubert, 1998), semânticas mais do que comunicativas (Newmark, 1981), estrangeirizadoras mais do que domesticadoras (Venuti, 1995, 2002). No entanto, a tipologia e o teor dos textos mais usualmente submetidos à tradução juramentada são de natureza institucional elou jurídica (documentos pessoais, históricos escolares e diplomas, procurações, instrumentos contratuais, títulos mobiliários, et simil), tendentes, portanto, a conter marcadores muito específicos da língua/cultura de partida. Essa é uma configuração que, em outros modos de tradução, faz o processo tradutório pender para soluções oblíquas (modulações e adaptações).

Esses marcadores culturais específicos, que tendem a soluções oblíquas ou mais distanciadas do ponto original, presumem um afastamento da constância supostamente exigida na condição juramentada da tradução. Quando o autor menciona "em outros modos de tradução", subentende uma permissividade que não pertence à tipologia juramentada, e reforça a tendência a evitar tal "movimentação" para fora do centro ou foco no texto de partida. Há um entendimento de que a maior proximidade ao original garantirá sua equivalência ou fidelidade exigida por lei.

Essa exigência legal é amparada pela força da fé pública, que se faz presente no processo de mediação desse dilema de invariança e diversidade cultural por parte do tradutor. Do ponto de vista da fé pública, espera-se que o tradutor público cumpra a sua função de realizar uma tradução, mediante a produção de um documento que possa servir ao seu propósito, sem impedimentos.

Diante disso, e considerando que esses pressupostos de invariância foram postulados em uma época anterior ao desenvolvimento vertiginoso de novas tecnologias, este trabalho tem por objetivo, com o auxílio das modalidades de tradução (Aubert, 2006), observar e expor como atuam os tradutores públicos hoje, ou seja, mapear as estratégias de tradução desses profissionais, nessa situação de maior disponibilidade de recursos e acesso a tecnologias para a prática tradutória.

Complementarmente, propomos descrever até que ponto o componente da fé pública ocasiona ou determina a visibilidade desse tradutor, bem como, mediante a comparação entre duas gerações de tradutores, nomeados em um intervalo de vinte anos, expor o perfil ou perfis de tradutores juramentados a partir das estratégias escolhidas. Essa força imposta pela fé 
pública nos conduziu à hipótese de que a visibilidade do tradutor torna-se acentuada em virtude da delegação desse poder.

Sendo assim, esta dissertação é composta por seis capítulos e, em virtude do sistema de numeração estabelecido pela norma da ABNT NBR 6024, o capítulo um consiste na presente introdução que, consequentemente, não descreveremos. O capítulo segundo introduz o tema da tradução juramentada com a apresentação de algumas notas históricas, que relatam desde o surgimento do ofício de tradutor público até os concursos para nomeação de tradutores mais recentes. Em seguida, é abordada a delegação da fé pública, a partir de sua definição e descrição dos tipos, com foco especial sobre sua relação com a visibilidade do tradutor público. Nessa segunda parte do capítulo, sugerimos cinco características de visibilidade.

No capítulo terceiro, apresentamos a fundamentação teórica a partir de uma breve discussão sobre os modelos de Berman (1985), Reiß (1971, 1976) e Baker (1996), e a respectiva aplicabilidade na tipologia da tradução juramentada. Em seguida, procedemos à descrição do modelo escolhido para aplicação em nosso corpus de pesquisa, ou seja, as modalidades de tradução de Aubert (2006). Essa segunda parte do capítulo é dedicada à descrição dos procedimentos técnicos de tradução de Vinay e Darbelnet (1958), que serviram como base para a concepção do modelo aubertiano. Ademais, buscamos traçar a evolução do modelo das modalidades de tradução de Aubert (1984, 1998, 2006), com destaque para as mudanças ocorridas. No final deste capítulo, é feito um detalhamento do modelo revisado de 2006, ilustrado por exemplos relativos à prática tradutória juramentada.

O capítulo quarto apresenta o material de estudo e a metodologia utilizada no trabalho. Na primeira parte do capítulo, descrevemos a composição do corpus de pesquisa e como foi realizada a coleta das doze traduções juramentadas. Na segunda parte, detalhamos as etapas metodológicas para os dois levantamentos realizados: (1) elaboração da lista para o primeiro levantamento de dados relativo à dispersão das soluções tradutórias; e (2) classificação dos dados em unidades lexicais para aplicação do modelo das modalidades de tradução de Aubert (2006) e obtenção dos dados estatísticos. 
As análises e a consolidação dos resultados obtidos são apresentadas no capítulo quinto. A princípio, descrevemos o perfil de cada tradutor individualmente, com base nos dados estatísticos obtidos e características observadas nas respectivas traduções. Foram observadas a aderência aos regulamentos da tradução juramentada, as formas de menção de carimbos e assinaturas, notas do tradutor, dentre outros itens relevantes para a classificação do perfil. Na sequência, procedemos ao relato dos resultados gerais, por grupo de tradutores, bem como pelo comparativo entre as duas gerações, com o auxílio de gráficos. Na última parte desse capítulo, são reunidas sugestões para a ferramenta de análise no tocante à classificação de textos pragmáticos.

O capítulo sexto, por fim, reúne nossa considerações finais acerca dos resultados obtidos na pesquisa, à luz da fundamentação teórica apresentada no capítulo três desta dissertação. Além disso, oferecemos sugestões para novos projetos de pesquisa na área, com vistas à continuidade dos estudos relativos à tradução juramentada. 


\section{A TRADUÇÃO JURAMENTADA}

\subsection{Notas históricas}

A entrada das tropas napoleônicas em Portugal, em 27 de novembro de 1807, ocasionou a vinda para o Brasil da Corte Portuguesa composta pelo regente, D. João VI, sua mãe, a rainha D. Maria I, os seus familiares e cortesãos, que aqui permaneceram de 1808 a 1821. Eram cerca de 15000 pessoas acomodadas em 34 embarcações de diversos calados que, com o apoio da esquadra inglesa, chegaram à Baía em 7 de março de 1808. O governo instalou-se na cidade do Rio de Janeiro e dentre os melhoramentos originados da estada da Corte no Brasil, que iriam lançar as bases do futuro país, pode-se citar a criação da Imprensa Nacional, a Fábrica da Pólvora e o Banco do Brasil para o financiamento de novas iniciativas (cf. Oliveira, 2005,25:41).

Segundo Oliveira (2005), a transferência da corte portuguesa para o Brasil, em 1808, "significou mudanças em muitos aspectos e em particular aos relacionados à estrutura e funcionamento do Estado, que, através das reformas pombalinas, estabeleceu novas diretrizes". Conforme o mesmo autor, a partir daquele momento, D. José I passa a ser representado por Sebastião José de Carvalho e Melo (Marquês de Pombal). Nesse conturbado momento, no Brasil, os cargos mais necessários e estratégicos para a manutenção da Coroa portuguesa eram os de tradutor e intérprete. Enfim, o Brasil abria os portos para as "nações amigas", em especial à Inglaterra. A primeira referência a essas profissões encontra-se no Alvará com força de lei, documento datado de 1754, no qual se lê: "Entre os requisitos exigidos para os cargos de intérprete e/ou tradutor estavam as habilidades linguísticas e o bom desempenho intelectual, além do grau de instrução do candidato ou do indicado" (OLIVEIRA, 2006:69).

O primeiro intérprete nomeado no Brasil foi Ildefonso José da Costa, designado pelo decreto de 10 de novembro de 1808. Seu ordenado anual era de 400,00 réis (Oliveira, 2005:25:41). A partir daquele 10 de novembro de 1808, "outros decretos nomeariam intérpretes para funções administrativas de norte a sul, para a Secretaria de Governo da Bahia, para o porto da ilha de Santa Catarina, para a fortaleza de Santa Cruz, para a Intendência Geral da Polícia, para as alfândegas do Rio de Janeiro, Bahia e Pernambuco” (Wyler 2003:42- 
43). Diante da abertura dos portos, que atrai para o litoral brasileiro um número crescente de comerciantes estrangeiros, o tradutor aparece em evidente posição de importância.

A expressão "jurado" aparece pela primeira vez no Decreto de 9 de dezembro de 1823, posterior à Independência, conforme transcrito a seguir:

Crêa o logar de traductor jurado da Praça e interprete da Nação. Tomando em consideração a necessidade de um Interprete de linguas estrangeiras, com fé publica, para a traducção dos differentes papeis relativos ao commercio: e concorrendo na pessoa de Eugenio Gildmester as qualidades necessarias para o bom desempenho deste trabalho, pelo preciso conhecimento que tem das linguas principaes da Europa: Hei por bem fazer-lhe mercê do officio de Traductor jurado da Praça e Interprete da Nação, sem ordenado algum, mas percebendo das partes, pelas referidas traducções, a quantia de $1 \$ 200$ por meia folha. A Mesa do Desembargo do Paço o tenha assim entendido, e lhe mande passar os despachos necessarios. Paço em 9 de Dezembro de $1823,2^{\circ}$ da Independencia e do Imperio. Com a rubrica de Sua Magestade o Imperador ${ }^{3}$.

No referido decreto, podemos observar também a menção à fé pública e a determinação do valor a ser pago por tradução, não havendo mais um salário anual.

No ano de 1850, ocorreu a criação do registro público do comércio, vinculado às secretarias dos tribunais do comércio, bem como a expedição de regulamentos para disciplinar questões processuais e os aludidos tribunais. Em 1851, houve a promulgação de regimentos para cuidar do ofício dos intérpretes do comércio. Nesse período, inicia-se, portanto, a organização das estruturas que, "somente em 1875, viriam a originar as juntas e inspetorias comerciais, mediante um decreto-legislativo que autorizava o governo a suprimir a jurisdição comercial e a compor os referidos órgãos para assumir as funções administrativa dos tribunais do comércio." 4

Nos anos seguintes à proclamação da República, em 1889, quase todos os estados organizam suas juntas comerciais; na época o presidente do Brasil era Deodoro da Fonseca. Em 1916, no mandato do Presidente Venceslau Brás, com a determinação no Código Civil de que "os escritos de obrigação redigidos em língua estrangeira serão, para ter efeitos legais no país, vertidos em português", aparece pela primeira vez a expressão "tradutor juramentado",

\footnotetext{
${ }^{3}$ A grafia será mantida conforme os textos originais nas citações.

${ }^{4}$ Informação obtida no site da Associação Profissional dos Tradutores Públicos e Intérpretes Comerciais do Estado de São Paulo (doravante ATPIESP), disponível em: http://atpiesp.org.br/timelinetraducao/\#
} 
no Código de Processo Civil que, por sua vez, estabelece que "só poderá ser junto aos autos documentos redigidos em língua estrangeira, quando acompanhado de versão em vernáculo, firmada por tradutor juramentado" (cf. nota 4, grifo nosso).

E, finalmente, em 21 de outubro de 1943 é expedido pelo presidente Getúlio Vargas o decreto $\mathrm{N}^{\mathrm{o}} 13.609$ que fixa a competência das Juntas Comerciais para disciplinar o ofício de tradutor juramentado vigente até os dias atuais. Em conformidade com o referido decreto, em seu Artigo 18:

\begin{abstract}
Nenhum livro, documento ou papel de qualquer natureza que fôr exarado em idioma estrangeiro, produzirá efeito em repartições da União dos Estados e dos municípios, em qualquer instância, Juízo ou Tribunal ou entidades mantidas, fiscalizadas ou orientadas pelos poderes públicos, sem ser acompanhado da respectiva tradução feita na conformidade dêste regulamento. (Artigo 18 do Decreto № 13.609)
\end{abstract}

Assim, nenhuma outra tradução terá fé pública se não for realizada por qualquer dos tradutores públicos e intérpretes comerciais nomeados de acordo com o regulamento ou por corretores de navios, no tocante aos manifestos e documentos das embarcações estrangeiras a serem apresentados nas Alfândegas, conforme estabelecido no Artigo 19 do referido Decreto 13.609. Em seguida, o presidente Castelo Branco promulgou a lei que incumbe às Juntas Comerciais "os encargos de fixar o número, processar a habilitação e a nomeação, fiscalizar, punir e exonerar os Tradutores Públicos e Intérpretes Comerciais" ". No Governo de Garrastazu Médici é aprovada a Lei de Registros Públicos que determina a necessidade de registro no Registro de Títulos e Documentos "de todos os documentos de procedência estrangeira, acompanhados das respectivas traduções, para produzirem efeitos em repartições da União, dos estados, do Distrito Federal, dos territórios e dos municípios ou em qualquer instância, juízo ou tribunal”, também ainda vigente. Finalmente, em 1956, foi realizado o primeiro concurso para Tradutor Público no Estado de São Paulo, estado esse no qual atuam os tradutores que realizaram as traduções analisadas no presente estudo, tendo o segundo concurso sido promovido pela Jucesp, em 1978.

No Estado de São Paulo, o ofício é também regido pela Deliberação n⿳ำ 04 de 01 de dezembro de 2000. Antes disso, foi ainda realizado pela Jucesp, em 1998, o terceiro concurso para Tradutor Público e Intérprete Comercial, conforme o Aviso de Pauta datado de 28 de julho de 2000:

\footnotetext{
${ }^{5}$ Informação extraída do site da ATPIESP: http://www.atpiesp.org.br
} 
O governador Mário Covas dará posse nesta sexta-feira, dia 28, às $11 \mathrm{~h} 30$, no Palácio dos Bandeirantes, aos tradutores públicos e intérpretes comerciais do Estado de São Paulo. São 1.310 profissionais que foram aprovados e habilitados no concurso público realizado pela Junta Comercial do Estado, da Secretaria da Justiça e da Defesa da Cidadania. O último concurso para tradutores públicos e intérpretes comerciais aconteceu há 20 anos. Com a escassez destes profissionais no mercado, em razão da abertura das relações comerciais entre países do Mercosul e da expansão da economia no mundo globalizado, tornou-se premente a nomeação de novos tradutores para atender a demanda. Os profissionais concorreram com mais de seis mil candidatos, que dominavam um ou mais dos 24 idiomas exigidos. Foram aprovados 738 em inglês, 273 em francês, 109 em espanhol, 129 em italiano, 75 em alemão, além de japonês, russo, chinês, latim, entre outros. Para a realização do concurso, um convênio foi firmado entre a Secretaria da Justiça e da Defesa da Cidadania, Junta Comercial do Estado, Associação Paulista de Educação e Cultura e Universidade de Guarulhos. A nomeação dos tradutores consta em Portaria 68/00, publicada no Diário Oficial do dia 13 de julho último. As informações também estão no site da Junta Comercial - www.jucesp.sp.gov.br.

Mesmo que outros estados do país não se relacionem diretamente à pesquisa, é importante notar que recentemente foram realizados concursos nos estados de Minas Gerais (2008), Santa Catarina (2009), Rio de Janeiro (2009), Rio Grande do Sul (2010), Ceará (2010), Pernambuco (2011), Pará (2011), Paraná (2011) e Sergipe (2012), pelas respectivas Juntas Comerciais, que constam da lista a seguir ${ }^{6}$ :

\begin{tabular}{|l|l|l|}
\hline \multicolumn{1}{|c|}{ Estado } & \multicolumn{1}{c|}{ Junta Comercial } & \multicolumn{1}{c|}{ Site na Internet } \\
\hline Acre (AC) & Juceac & www.juntacomercialac.com.br \\
\hline Alagoas (AL) & Juceal & www.juceal.al.gov.br \\
\hline Amapá (AP) & Jucap & www.jucap.ap.gov.br \\
\hline Amazonas (AM) & Jucea & www.jucea.am.gov.br \\
\hline Bahia (BA) & Juceb & www.juceb.ba.gov.br \\
\hline Ceará (CE) & Jucec & www.jucec.ce.gov.br \\
\hline Distrito Federal (DF) & Jcdf & www.jcdf.desenvolvimento.gov.br \\
\hline Espírito Santo (ES) & Jucees & www.jucees.es.gov.br \\
\hline Goiás (GO) & Juceg & www.juceg.go.gov.br \\
\hline Maranhão (MA) & Jucema & www.jucema.ma.gov.br \\
\hline Mato Grosso (MT) & Jucemat & www.jucemat.mt.gov.br \\
\hline Mato Grosso do Sul (MS) & Jucems & www.jucems.ms.gov.br \\
\hline Minas Gerais (MG) & Jucemg & www.jucemg.mg.gov.br \\
\hline Pará (PA) & Jucepa & www.jucepa.pa.gov.br \\
\hline Paraíba (PB) & Jucep & www.jucep.pb.gov.br \\
\hline Paraná (PR) & Jucepar & www.jucepar.pr.gov.br \\
\hline Pernambuco (PE) & Jucepe & www.jucepe.pe.gov.br \\
\hline Piauí (PI) & Jucepi & www.jucepi.pi.gov.br \\
\hline Rio de Janeiro (RJ) & Jucerja & www.jucerja.rj.gov.br \\
\hline
\end{tabular}

\footnotetext{
${ }^{6}$ A lista foi elaborada mediante consulta pela ferramenta de busca Google da expressão "Junta Comercial” e o nome do respectivo estado.
} 


\begin{tabular}{|l|l|l|}
\hline \multicolumn{1}{|c|}{ Estado } & \multicolumn{1}{c|}{ Junta Comercial } & \multicolumn{1}{c|}{ Site na Internet } \\
\hline Rio Grande do Norte (RN) & Jucern & www.jucern.rn.gov.br \\
\hline Rio Grande do Sul (RS) & Jucergs & www.jucergs.rs.gov.br \\
\hline Rondônia (RO) & Jucer & www.jucer.ro.gov.br \\
\hline Roraima (RR) & Jucerr & http://www.jucerr.rr.gov.br/ \\
\hline Santa Catarina (SC) & Jucesc & www.jucesc.sc.gov.br \\
\hline Sergipe (SE) & Jucese & www.jucese.se.gov.br \\
\hline São Paulo (SP) & Jucesp & www.jucesp.sp.gov.br \\
\hline Tocantins (TO) & Jucetins & www.jucetins.to.gov.br \\
\hline
\end{tabular}

Quadro 2.1.1 - Relação das Juntas Comerciais

É importante destacar que os concursos não são realizados com grande frequência, muito provavelmente devido à complexidade e estruturas necessárias para a avaliação dos diversos idiomas envolvidos (aproximadamente vinte e quatro). Ademais, não existe nenhum programa de integração ou material de apoio ao ofício dos novos profissionais nomeados na maioria das juntas comerciais pesquisadas, fato que nos motivou ainda mais a realizar a pesquisa que ora apresentamos nesta dissertação.

As informações provenientes das Juntas Comerciais disponíveis aos tradutores referem-se apenas aos valores a serem cobrados e à regulamentação vigente. A lei que dispõe a competência das Juntas Comerciais para elaborar a Tabela de Preços dos Serviços de Tradutores e Intérpretes é datada de 18 de novembro de 1994 no Governo de Itamar Franco ${ }^{7}$. No estado de São Paulo, a tabela de emolumentos determina valores diferenciados para a tradução e versão. Há também a distinção do tipo de texto, entre comuns (passaportes, certidões de registros civis, cédula de identidade, habilitação profissional e documentos similares) ou especiais (jurídicos, técnicos e científicos, bancários e contábeis, certificados e diplomas escolares). Algumas Juntas Comerciais de outros estados estabelecem um único valor para tradução e versão. No quadro a seguir, apresentamos os valores atuais referentes à tradução:

\begin{tabular}{|l|l|l|l|l|}
\hline \multicolumn{1}{|c|}{ Junta Comercial } & \multicolumn{1}{|c|}{$\begin{array}{c}\text { Tradução/Versão } \\
\text { Unificadas }\end{array}$} & Valor Texto Comum & \multicolumn{1}{|c|}{$\begin{array}{c}\text { Valor Texto } \\
\text { Técnico }\end{array}$} & $\begin{array}{c}\text { Interpretação } \\
\mathbf{1}^{\text {a }} \text { hora }\end{array}$ \\
\hline Juceac & Sem informação & & & \\
\hline Juceal & Sem informação & & & \\
\hline Jucap & Sem informação & & & \\
\hline Jucea & Sem informação & & & \\
\hline Juceb & Sim & $\mathrm{R} \$ 39,00$ & $\mathrm{R} \$ 56,00$ & $\mathrm{R} \$ 128,00$ \\
\hline Jucec & Não & $\mathrm{R} \$ 55,00$ & $\mathrm{R} \$ 60,00$ & $\mathrm{R} \$ 200,00$ \\
\hline Jcdf & Sim & $\mathrm{R} \$ 41,00$ & $\mathrm{R} \$ 54,00$ & $\mathrm{R} \$ 120,00$ \\
\hline Jucees & Não & $\begin{array}{l}\text { 20 VRTE } \\
\text { (Valor de Referência } \\
\text { do Tesouro Estadual) }\end{array}$ & 23 VRTE & 86 VRTE \\
\hline
\end{tabular}

\footnotetext{
${ }^{7}$ Informação extraída do site da ATPIESP: http://www.atpiesp.org.br
} 


\begin{tabular}{|c|c|c|c|c|}
\hline Junta Comercial & $\begin{array}{c}\begin{array}{c}\text { Tradução/Versão } \\
\text { Unificadas }\end{array} \\
\end{array}$ & Valor Texto Comum & $\begin{array}{c}\text { Valor Texto } \\
\text { Técnico } \\
\end{array}$ & $\begin{array}{c}\text { Interpretação } \\
\text { 1ํㅡㅁ }^{\mathrm{a}} \text { hora }\end{array}$ \\
\hline Juceg & Sim & $\mathrm{R} \$ 33,00$ & $\mathrm{R} \$ 44,00$ & $\mathrm{R} \$ 63,00$ \\
\hline Jucema & Sim & $\mathrm{R} \$ 35,00$ & $\mathrm{R} \$ 50,00$ & $\mathrm{R} \$ 135,00$ \\
\hline Jucemat & Não & $\begin{array}{l}3 \text { UPF/MT } \\
\text { (Unidade Padrão } \\
\text { Fiscal de Mato Grosso } \\
\text { - valor atualizado } \\
\text { semestralmente) }\end{array}$ & 5 ou 6 UPF/MT & $3 \mathrm{UPF} / \mathrm{MT}$ \\
\hline Jucems & Sim & $\begin{array}{l}\text { UFERMS (Unidade } \\
\text { Fiscal de Referência } \\
\text { do Estado de Mato } \\
\text { Grosso do Sul) } \\
1.5408\end{array}$ & $\begin{array}{l}\text { UFERMS } \\
2.1571\end{array}$ & $\begin{array}{l}\text { UFERMS } \\
6.1634\end{array}$ \\
\hline Jucemg & Não & $\mathrm{R} \$ 46,37$ & $\begin{array}{l}\mathrm{R} \$ 58,94 \\
\text { Alta complexidade } \\
\text { valor } \mathrm{R} \$ 74,38\end{array}$ & $\mathrm{R} \$ 202,85$ \\
\hline Jucepa & Sim & $\mathrm{R} \$ 59,00$ & $\mathrm{R} \$ 72,00$ & $\mathrm{R} \$ 120,00$ \\
\hline Jucep & Sem informação & & & \\
\hline Jucepar & Não & $\mathrm{R} \$ 38,00$ & $\mathrm{R} \$ 54,00$ & $\mathrm{R} \$ 125,00$ \\
\hline Jucepe & Não & $\mathrm{R} \$ 55,00$ & $\mathrm{R} \$ 60,00$ & \\
\hline Jucepi & Sem informação & & & \\
\hline Jucerja & Não & $\mathrm{R} \$ 36,00$ & $\begin{array}{l}\mathrm{R} \$ 48,00 \\
\text { Alta complexidade } \\
\text { valor } \mathrm{R} \$ 74,00\end{array}$ & $\mathrm{R} \$ 374,00$ \\
\hline Jucern & Taxa de $\mathrm{R} \$ 172,00 \mathrm{DA}$ & C (Documento de Arrec & adação de Registro d & Comércio) \\
\hline Jucergs & Não & $\mathrm{R} \$ 35,00$ & $\mathrm{R} \$ 58,00$ & $\mathrm{R} \$ 150,00$ \\
\hline Jucer & Não & $\begin{array}{l}\text { R\$ 25,00 Tradução } \\
\text { R\$ 35,00 Versão }\end{array}$ & $\begin{array}{l}\text { R\$ 25,00 Tradução } \\
\text { R\$ 35,00 Versão }\end{array}$ & $\mathrm{R} \$ 100,00$ \\
\hline Jucerr & Não & $\mathrm{R} \$ 35,00$ & $\mathrm{R} \$ 40,00$ & \\
\hline Jucesc & Não & $\mathrm{R} \$ 39,00$ & $\begin{array}{l}\mathrm{R} \$ 54,00 \\
\text { Alta complexidade } \\
\text { valor } \mathrm{R} \$ 82,00\end{array}$ & $\mathrm{R} \$ 125,00$ \\
\hline Jucese & Não & $\mathrm{R} \$ 55,00$ & $\mathrm{R} \$ 60,00$ & $\mathrm{R} \$ 180,00$ \\
\hline Jucesp & Não & $\mathrm{R} \$ 40,28$ & $\mathrm{R} \$ 49,95$ & $\mathrm{R} \$ 140,17$ \\
\hline Jucetins & Sem informação & & & \\
\hline
\end{tabular}

Quadro 2.1.2 - Tabela de Emolumentos - Valores para Tradução de Língua Estrangeira para Vernáculo ${ }^{8}$

Observamos que há uma autonomia das Juntas Comerciais para a determinação dos valores. Nos estados de Minas Gerais e Santa Catarina existe até uma distinção de valores referentes a documentos técnicos de alta complexidade.

Além da delegação da fé pública, o tradutor nomeado em concurso, conforme anteriormente mencionado, estará sujeito à deliberação que rege seu ofício. Vejamos no quadro a seguir as diversas regulamentações de cada estado:

\footnotetext{
${ }^{8}$ Informações extraídas dos sites das respectivas Juntas Comerciais. Atualmente, os valores da tabela da Jucesp são os seguintes: valor texto comum - R $\$ 42,50$, valor texto técnico - R $\$ 59,50$ e interpretação $1^{a}$ hora R\$147,90 (cf. Deliberação Jucesp de 29/07/2015 nº 04).
} 


\begin{tabular}{|c|c|c|}
\hline Junta Comercial & Legislação Vigente & Observações \\
\hline Juceac & & Tradutores Ad-doc ${ }^{9}$ Matriculados \\
\hline Juceal & $\begin{array}{l}\text { A Junta Comercial de Alagoas informa que, } \\
\text { conforme Instrução Normativa n }{ }^{\circ} 84 \text {, de } 29 \text { de } \\
\text { fevereiro de } 2000 \text {, qualquer cidadão brasileiro } \\
\text { pode praticar a atividade de tradutor "Ad Hoc", } \\
\text { bastando somente cumprir os requisitos que a } \\
\text { mesma determina. Manual do Tradutor "Ad Hoc" }\end{array}$ & $\begin{array}{l}\text { Em Alagoas não houve concurso } \\
\text { público, portanto, a lista disponibilizada } \\
\text { configura-se apenas como indicação. } \\
\text { Nela constam os nomes daqueles que } \\
\text { frequentemente exercem suas funções } \\
\text { junto à Juceal, não sendo uma listagem } \\
\text { na íntegra dos habilitados para tal } \\
\text { exercício. }\end{array}$ \\
\hline Jucap & Sem servidor & \\
\hline Jucea & Sem informação & \\
\hline Juceb & $\begin{array}{l}\text { Decreto } 13.609 \text { de } 21 \text { de outubro de } 1943 ; \\
\text { Lei Federal } 8934 / 94 ; \\
\text { Decreto Federal 1800/96; } \\
\text { Instrução Normativa DNRC n- } 84 / 00\end{array}$ & \\
\hline Jucec & $\begin{array}{l}\text { Art.14 da Instrução Normativa n }{ }^{\circ} 84 \text { de } \\
29 / 01 / 2000\end{array}$ & \\
\hline Jcdf & Instrução Normativa $\mathrm{N}^{0} 107$, de 23 de maio de 2008 & \\
\hline Jucees & Resolução 02/2005 & \\
\hline Juceg & $\begin{array}{l}\text { Instrução Normativa № } 84 \text {, de } 29 \text { de fevereiro de } \\
2000\end{array}$ & \\
\hline Jucema & Instrução Normativa 84/2000 & \\
\hline Jucemat & $\begin{array}{l}\text { Instrução Normativa do DNRC-In n }{ }^{0} 84 \text { de } \\
29 / 02 / 2000\end{array}$ & \\
\hline Jucems & Edital No $004 / 2012$, de $29 / 03 / 2012$ & \\
\hline Jucemg & Resolução RP/07/2012 de 18 de outubro de 2012 & \\
\hline Jucepa & 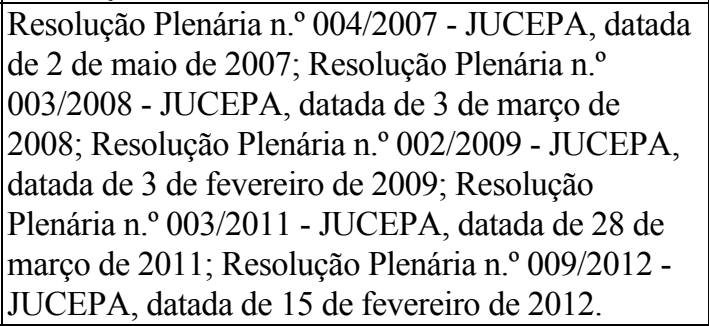 & \\
\hline Jucep & $\begin{array}{l}\text { Instrução Normativa № } 84 / \text { DNRC, de } 29 \text { de } \\
\text { fevereiro de } 2000 \text { do Art. } 13^{\circ} \text { Portaria } \mathrm{N}^{\mathrm{o}} \\
015 / 2005 \text { publicado no Diário Oficial } 16 / 06 / 2005\end{array}$ & \\
\hline Jucepar & $\begin{array}{l}\text { Decreto } 13.609 \text { de } 21 \text { de outubro de } 1943 ; \\
\text { Lei Federal } 8934 / 94 ; \\
\text { Decreto Federal 1800/96; } \\
\text { Instrução Normativa DNRC no } 84 / 00\end{array}$ & \\
\hline Jucepe & Sem informação & \\
\hline Jucepi & Sem informação & \\
\hline Jucerja & Deliberação № 106, de 29 de setembro de 1998 & \\
\hline Jucern & Sem informação & \\
\hline Jucergs & Resolução 001 de 2010 & \\
\hline Jucer & Resolução № 075/Jucer, de 23 de março de 2001 & \\
\hline Jucerr & & $\begin{array}{l}\text { Tradutores Ad-doc Credenciados na } \\
\text { Junta Comercial do Estado de Roraima }\end{array}$ \\
\hline Jucesc & Resolução No 04/10, de 31/03/10 & \\
\hline Jucese & Instrução Normativa № 84 , de 29 de fevereiro de & Governador Marcelo Déda autoriza \\
\hline
\end{tabular}

${ }^{9}$ Tradutor ad hoc é, então, a pessoa incumbida para realizar a tradução de um determinado idioma, por meio de nomeação da Junta Comercial, para um único e exclusivo ato. Definição obtida no site da Juceal, no Manual do Tradutor Ad Hoc, uma vez que no Estado de Alagoas não foram realizados concursos públicos. Disponível em: http://www.juceal.al.gov.br/uploads/weblinks/manual_tradutor_ad_hoc.pdf 


\begin{tabular}{|c|c|c|}
\hline Junta Comercial & Legislação Vigente & Observações \\
\hline & 2000 & concurso em $24 / 01 / 12$ \\
\hline Jucesp & Deliberação n ${ }^{0} 04$ de 01 de dezembro de 2000 & \\
\hline Jucetins & $\begin{array}{l}\text { Instrução Normativa } \mathrm{N}^{0} \text { - } 44 \text {, de } 29 \text { de fevereiro de } \\
2000\end{array}$ & $\begin{array}{l}\text { A JUCETINS informa que não consta } \\
\text { matriculado Tradutor Público e } \\
\text { Intérprete Comercial Juramentado no } \\
\text { Estado do Tocantins. }\end{array}$ \\
\hline
\end{tabular}

Quadro 2.1.3 - Legislação Vigente ${ }^{10}$

Em nossa pesquisa, limitamos a coleta do corpus ao estado de São Paulo, porém, seria interessante, como sugestão para trabalhos futuros, ampliar a pesquisa pela coleta de traduções em diversos estados. Quanto à proximidade de realização de um novo concurso em São Paulo, de modo geral, dependerá da dinâmica do mercado e da quantidade de tradutores efetivamente atuantes no ofício.

\subsection{A fé pública e a visibilidade do tradutor}

A palavra fé, de acordo com a etimologia, tem origem no Latim "fides", fidelidade, e no Grego "pistia", que indica a noção de acreditar. Em sentido amplo, fé significa "crença", "confiança", "credibilidade"11 e, no contexto cotidiano, a palavra fé é utilizada para representar o sentimento de total crença ou esperança que algo seja verdade, mesmo que não haja nenhuma evidência ou comprovação.

O Moderno dicionário da língua portuguesa - Michaelis online apresenta as seguintes definições:

fé $\boldsymbol{s} \boldsymbol{f}$ (lat fide) 1 Crença, crédito; convicção da existência de algum fato ou da veracidade de alguma asserção. 2 Crença nas doutrinas da religião cristã. 3 A primeira das três virtudes teologais. 4 Fidelidade a compromissos e promessas; confiança: Homem de fé. 5 Confirmação, prova. 6 Testemunho de certos funcionários que faz força nos tribunais; confirmação de um testemunho. $\boldsymbol{F}$. conjugal: fidelidade que reciprocamente se devem os cônjuges. $\boldsymbol{F}$. de carvoeiro: crença inabalável, que não tende a razões ou argumentos. $\boldsymbol{F}$. de Cristo: a crença ou a religião cristã. $\boldsymbol{F}$. de oficio: a) folha de serviços de um funcionário ou de um militar; b) fé baseada na honra do cargo ou profissão de quem atesta ou abona. $\boldsymbol{F}$. de réu:

\footnotetext{
${ }^{10}$ Informações extraídas dos sites das respectivas Juntas Comerciais.

${ }^{11}$ Disponível em: http://www.significados.com.br/fe/
} 
certidão pela qual o oficial público declara haver citado alguém para qualquer fim. $\boldsymbol{F}$. divina: crença que se apoia na revelação. $\boldsymbol{F}$. humana: a que se assenta na autoridade dos homens. $\boldsymbol{F}$. implícita: a que, sem prévio exame, se deposita em alguma coisa. $\boldsymbol{F}$. pública: confiança que as instituições ou os magistrados públicos nos inspiram. $\boldsymbol{F}$. púnica: promessa desleal, traição. "Mais vale a fé que o pau da barca" (provérbio): aplica-se quando algo aconteceu como por milagre. Boa fé: a) convicção de agir de acordo com a lei; b) ausência de má intenção. Má fé: má intenção; maldade. ${ }^{12}$

Assim, encontramos acepções para a palavra fé aplicadas a diversos contextos, seja no contexto social, como nas expressões boa fé, má fé; no religioso, para designar um sistema de crenças religiosas (fé cristã); em expressões populares, tais como, fazer fé com o significado de acreditar em alguém ou algo, ter esperança; botar fé, que expressa o sentimento de confiança, reconhecimento e aceitação; e dar fé, em um contexto notadamente jurídico, para significar "afirmar como verdade, testificar, autenticar, prestar testemunho autêntico" (cf. nota 11).

A explicação acima no dicionário Michaelis para a rubrica fé pública é iniciada pela palavra confiança, a qual é reforçada por sinônimos encontrados também no início de outras definições obtidas em dicionários e sites de busca, tal como na definição de fé, substantivo feminimo, rubrica 6.6 jur credibilidade que deve ser dada ao documento no qual se funda, resultando disso a própria veracidade do documento; ${ }^{13}$ e na definição de fé pública 1 . jur crédito que se deve dar a documentos emanados de autoridades públicas ou serventuários da justiça, em virtude da função ou ofício exercido. ${ }^{14}$

Logo, a fé pública implica em confiança, credibilidade e crédito, quesitos fundamentais para a expressão da verdade. Segundo Aurélio Buarque H. Ferreira, fé pública é a "presunção legal de autenticidade, verdade ou legitimidade de ato emanado de autoridade ou funcionário autorizado, no exercício de suas respectivas funções." ${ }^{15}$

Isso significa que, para o funcionamento da sociedade, o Estado como representante do povo e seu regulamentador, para o desenvolvimento de suas múltiplas atividades, atribui a

\footnotetext{
${ }^{12}$ Disponível em: http://michaelis.uol.com.br/moderno/portugues/definicao/fe_74701.html

${ }^{13}$ Disponível em: https://www.google.com.br/\#q=fé+definições

${ }^{14}$ Disponível em: https://www.google.com.br/\#q=fé+pública+definições

${ }^{15}$ Definição extraída do Pequeno Dicionário Brasileiro da Língua Portuguesa, Edit. Civilização, RJ, $10^{\mathrm{a}}$ ed. s/d
} 
determinados cidadãos, nos termos da Constituição, o direito de representação para exercer tarefas específicas. Assim, a instituição de Direito Público atribui a certas pessoas a qualidade da verdade ao que atestam e afirmam. Dentre esses representantes, estão inseridos "o oficial de registro público, o serventuário, o tabelião, o escrivão, dentre outros, cujas atividades autenticam e dão como verdadeiros os atos praticados por outras pessoas em suas diversas tratativas." 16

Portanto, essa forma de declarar que certo ato está perfeitamente garantido pelos diplomas legais é a fé pública, ou seja, é real, verídica e legal, que obriga as partes envolvidas e ao mesmo tempo as mantém amparadas pelo Direito, isentas de qualquer dúvida, claro, até que provem o contrário.

O tradutor público e intérprete comercial aprovado em concurso e nomeado pela Junta Comercial de seu respectivo Estado também é depositário da fé pública e se distingue dos demais tradutores. Logo no início, no capítulo I da deliberação Jucesp n⿳⺈ 04 de 01 de novembro de $2000^{17}$, que regulamenta o exercício do ofício, fica estabelecida a delegação da fé pública em seu artigo $2^{\underline{O}}$.

Artigo $2^{\circ}$. Os tradutores públicos e intérpretes comerciais nomeados pela Junta Comercial terão jurisdição em todo o território do Estado de São Paulo, onde exercerão seus respectivos ofícios de acordo com as prerrogativas que lhes são conferidas por lei. Entretanto, terão fé pública, em todo o país, as traduções ou versões por eles feitas e as certidões que passarem. (grifo nosso)

Sendo assim, gozando de fé pública, em geral ao final da tradução, o tradutor apõe sua assinatura e sinal (na forma de selo ou carimbo), e declara que determinado ato foi praticado absolutamente isento de inverdade, dúvida ou suspeita, por intermédio da expressão "dou fé", prática essa constante, conforme podemos observar na definição de fé pública no dicionário Vocabulário Jurídico de Plácido e Silva (2009:611), da Editora Forense:

é a confiança que se deve ter a respeito dos documentos emanados de autoridades públicas ou de serventuários da Justiça, em virtude da função ou ofício exercido. A fé pública assenta, assim, na presunção legal de autenticidade dada aos atos praticados pelas pessoas que exercem cargo ou ofício público. [...] É costume, nas escrituras públicas ou documentos

\footnotetext{
${ }^{16}$ Disponível em: http://www.irib.org.br/html/biblioteca/biblioteca-detalhe.php?obr=198

${ }^{17}$ Disponível em: http://www.institucional.jucesp.sp.gov.br/downloads/Deliberacao_Jucesp_04_de_01.11.pdf
} 
passados por serventuários públicos, afinal, encerrarem-nos com a expressão: dou fé ou porto por fé, o que significa: asseguro ou certifico a verdade das ocorrências anotadas. (grifo nosso)

Nesse mesmo prisma, fazendo um paralelo com a língua inglesa, ao verificarmos o dicionário bilíngue jurídico Maria Chaves de Mello (1998:95), encontramos a tradução para fé pública como "full faith and credit (a credibilidade total que é dispensada à veracidade e firmeza de um ato oficial)", e no dicionário jurídico Noronha (1994:389), "authority to attest documents; full faith and credit", ou seja, novamente está presente a ideia de crédito, confiança, boa reputação.

Esse fraseologismo é muito frequente nos documentos oficiais dos Estados Unidos, como por exemplo no trecho abaixo retirado da legalização do Departamento de Estado, que em geral acompanha e autentica o selo de outra legalização emitida por alguma das diversas Secretarias de Estado nos Estados Unidos da América:

\title{
United States of America
}

\author{
DEPARTMENT OF STATE \\ To all to whom these presents shall come, Greetings: \\ I Certify That the document hereunto annexed is under the Seal of the Secretary of State of \\ the State(s) of Delaware, and that such Seal(s) is/are entitled to full faith and credit.* \\ *For the contents of the annexed document,the Department assumes no responsibility \\ This certificate is not valid if is removed or altered in any way whatsoever
}

Figura 2.2.1: Legalização do Departamento de Estado dos Estados Unidos da América

(Tradução nossa:)

\section{Estados Unidos da América}

(Brasão de armas)

\section{DEPARTAMENTO DE ESTADO}

A quem possa interessar: 
Certifico, para os devidos fins, que o documento anexo contém o Selo do Secretário de Estado de Delaware e que a esse Selo deve ser dada plena fé pública.*

\section{*O Departamento não se responsabiliza pelo teor do documento anexo Qualquer alteração ou rasura invalida este certificado}

Conforme o dicionário monolíngue jurídico da língua inglesa, Black's Law Dictionary (2004:695), full faith and credit significa "o reconhecimento, aceitação e cumprimento das leis, decisões e sentenças de outra jurisdição; especificamente, o reconhecimento por um estado das decisões jurídicas de outro estado." ${ }^{\prime 18}$ O que significa dizer que as leis, despachos e sentenças prolatadas por juízo competente de um estado (país) são reconhecidas, aceitas e podem ser executadas em outro estado. Em nosso exemplo acima, é reconhecida a veracidade do Selo do Secretário de Estado de Delaware e fica claro, pela ressalva apresentada na legalização: "O Departamento não se responsabiliza pelo teor do documento anexo", que nesse caso apenas o selo é autenticado e não o conteúdo do referido documento.

Desse modo, juridicamente, fica entendido que os atos de fé pública, que incluem a tradução juramentada, como no caso da tradução de uma carta rogatória solicitando a realização de diligências em outro Estado (país) ou, por exemplo, da oitiva de uma testemunha (entenda-se: a tomada de um depoimento), são reconhecidos pelo outro Estado por serem traduções juramentadas realizadas por tradutor público nomeado. Zavaglia e Poppi (2012:82) também concluem:

\footnotetext{
Assim, a tradução juramentada deve permitir, no país ao qual ela é destinada, que a comunicação dos efeitos oficiais previstos no país de origem, incluída a fé pública da qual é portadora, seja realizada de fato no país de destino, sem que as instâncias nacionais se confundam.
}

Isto posto, além dos tradutores públicos e intérpretes comerciais, conforme mencionamos anteriormente, também estão “investidos de fé pública, escrivães de polícia, chefes do poder executivo, magistrados, oficiais de registro civil, notários e agentes dos departamentos de trânsito estaduais no exercício de suas funções". ${ }^{19}$ Nesse sentido, a título de exemplificação, destacamos três tipos de fé pública, a saber, a fé pública notarial, a registral e a dos agentes de trânsito. Rezende (1998:4) cita outras formas distintas:

\footnotetext{
${ }^{18}$ No original: "the recognition, acceptance and enforcement of the laws, orders, and judgments of another jurisdiction; specif., the recognition by one state of another state's legal decisions."

${ }^{19}$ Disponível em: http://pt.wikipedia.org/wiki/Fé_pública e http://www.jusbrasil.com.br/busca?q=FÉ+PÚBLICA+DOS+ATOS\&c=
} 
o âmbito do desenvolvimento da fé pública é tão amplo como o das relações jurídicas que se referem a toda atividade humana, razão pela qual há distintas formas: a geral, a especial, a judicial, a administrativa e a extrajudicial, tendo essa última como depositário dominante, o notário, embora existam outras pessoas que desempenhem a fé pública em atividade notarial, como por exemplo, os cônsules e os militares, entre outros. ${ }^{20}$

Dentre as citadas, a fé pública notarial é uma das mais conhecidas, na figura do notário ou tabelião, que ao declarar que uma cópia confere com o original, por exemplo, empresta ao documento, com o selo e com a sua assinatura, a autenticidade como se original fosse. Todavia, os notários exercem também outras funções, com total isenção de influência na vontade das partes, como prestar assessoria às partes sobre o negócio jurídico a ser realizado, certificar-se de que os contratantes compreenderam perfeitamente o conteúdo, além de "redigir o escrito que se converterá em instrumento público; autorizar o instrumento público, dando-lhe forma pública e credibilidade; conservar o instrumento autorizado; expedir cópias do instrumento" (Brandelli, 1998: 126).

A atividade notarial é "uma das mais remotas atividades jurídicas já desempenhadas pelo ser humano. A crer em registros deixados pelas civilizações longínquas, a referida atividade já era tradição na Roma antiga" (Lima, 2011:1). Naquela época, o notário (ou notarius, como era chamado) era responsável pela realização de transcrições e registros de julgamentos e de procedimentos judiciais.

Havia também "o tabelione, que era responsável pela formalização da vontade das partes através de minutas, as quais eram redigidas sobre tábuas, com assinatura das partes, testemunhas e tabeliones" (Lima, 2011:1). As funções do tabelione, conforme Raposo (1986:689-690), são as que mais se aproximam do notário de hoje, sendo que ambas as funções de notário e de tabelião resistiram ao efeito do tempo, com as devidas nuances.

Ao compararmos o notary public americano com o tabelião público brasileiro, verificamos que as funções exercidas são semelhantes, diferenciando-se apenas pela forma de habilitação para o cargo e respectiva fiscalização. Aubert (2005) comenta, ao abordar as semelhanças e diferenças entre tabelião e notário, que o grau de semelhança entre o notary public britânico e o tabelião público brasileiro é ainda maior e "talvez por esse motivo, os

\footnotetext{
${ }^{20}$ Disponível em: http://www.irib.org.br/html/biblioteca/biblioteca-detalhe.php?obr=198
} 
consulados brasileiros localizados nos EUA, ao autenticarem a assinatura do notary public, designam-no como notário público (termo, aliás, que começa a se fazer corrente também no Brasil); já os consulados brasileiros no Reino Unido tendem a referir-se a esses oficiais como tabeliães" (Aubert, 2005:251, grifos do autor).

No Brasil, a título de curiosidade, a atividade notarial e registral surgiu, conforme relata Lima (2001:1):

\begin{abstract}
a partir do registro do vigário (Lei n. 601/1850 e Dec. 1318/1854), com o que a Igreja Católica passou a obrigar a legitimação da aquisição pela posse, através do registro em livro próprio, passando a diferençar as terras públicas das terras privadas. A aludida transmissão, com o tempo, passou a ser realizada através de contrato e, não raras vezes, necessitava de instrumento público, confeccionado por um tabelião. Finalmente, com a amplicação (sic) do atos registráveis, passaram a se submeter ao Registro Geral (Lei n. $1237 / 1864$ ) todos os direitos reais sobre bens imóveis.
\end{abstract}

Essa obrigação da legitimação da posse nos leva ao segundo tipo de fé pública exemplificado, a fé pública registral, que está relacionada aos negócios imobiliários. As partes interessadas em um imóvel confiam nas informações contidas no registro predial para dar continuidade à aquisição. Assim como na fé pública notarial, a fé pública registral, resume-se na "crença da verdade". Nessa mesma esteira, podemos exemplificar o terceiro tipo de fé pública, do policial ou agente de trânsito, que ao preencher um auto de infração, utiliza de sua fé pública para que se presuma que aquela infração realmente ocorreu.

Apesar da diversidade, todos os tipos de fé pública atendem a um propósito idêntico de garantir às relações jurídicas a autenticidade, a certeza, a estabilidade e a indiscutibilidade. A vida social requer estabilidade em suas relações para que possam alcançar a evidência e permanência legais, ou seja, a segurança jurídica.

Rezende (1998:5) reforça a contribuição da segurança jurídica pelos atos desses agentes ao afirmar que:

Profissionalismo independente e fé pública aparecem indissoluvelmente unidos a serviço do interesse público, assegurando a contribuição notarial ao princípio constitucional de segurança jurídica, perante a esfera privada, pois que os notários são portadores dessa garantia legalmente outorgada.

O profissionalismo citado deve-se ao fato de o tabelião público (e, similarmente, o tradutor público e intérprete comercial) não ser qualificado como funcionário público, mas delegado da fé pública, que atua de forma independente; todavia, fortemente regulamentada e 
disciplinada pelas respectivas resoluções e decretos que regem o ofício. A referida independência profissional aliada à fé pública permitem a validação dos atos jurídicos em prol do interesse público.

Percebe-se, desse modo, que a principal finalidade da fé pública é a segurança jurídica que deve prevalecer nas relações negociais realizadas pela sociedade, "cujo valor atinge um raio de ação na totalidade do ordenamento jurídico, tanto assim que, a maior segurança de um documento notarial, está na razão do mesmo ser considerado público, quando proclama urbi et orbi a finalidade e certeza jurídica ali existentes" (Rezende, 1998:6); ou seja, a validade do documento se estenderá urbi et orbi, "expressão latina que significa 'para a cidade e para o universo' (sendo Roma a cidade de referência), significado que pode resumir-se em 'por toda parte'. Essa expressão faz parte da bênção do Sumo Pontífice, significando que ela se estende ao universo inteiro" (Neves, 2003:773).

Isto posto, pode-se dizer que a visibilidade do tradutor público é notória em face da delegação da fé pública. Wyler (2003:16) destaca em seu livro a visibilidade do tradutor juramentado quando afirma que "o único segmento regulamentado da categoria, desde o século XIX, é o dos Tradutores Públicos e Intérpretes Comerciais, que prestam concurso público e são nomeados pelas Juntas Comerciais estaduais”. Na verdade, conforme dissemos na página 22 desta dissertação, foi regulamentado em 1943. A autora faz ainda uma comparação com a invisibilidade do tradutor em geral, em virtude de seu isolamento por trabalhar em casa e só conhecer o cliente pelo e-mail, ou voz ao telefone apenas, mas principalmente, pela falta de regulamentação da profissão. Ademais, há pouco tempo que notamos a inclusão do nome do tradutor em filmes, livros, resenhas, anteriormente omitidos pela imprensa.

Sendo assim, tendo em vista essa distinção como único segmento regulamentado e as considerações acima a respeito da fé pública inerente ao cargo, observamos características particulares à visibilidade do Tradutor Público e Intérprete Comercial que designamos da seguinte maneira: a) imediata; b) diferenciada; c) subordinada; d) registrada; e e) interferente.

Considerando uma abordagem mais prática, a visibilidade do tradutor público é imediata, uma vez que a tradução é entregue em papel impresso, devidamente aprovado pela 
Junta Comercial do Estado, cujo timbre traz o nome do tradutor, seus dados pessoais de identificação como RG e CPF, incluindo sua matrícula na junta comecial à qual está ligado, os idiomas para os quais está habilitado e seu endereço de ofício.

É diferenciada por conta do poder conferido pela fé pública, que faz com que a tradução valide o documento original, para todos os fins, para que produza os devidos efeitos jurídicos. De certo modo, essa diferenciação imposta por força das responsabilidades inerentes ao seu cargo faz com que o tradutor realize seu trabalho como se houvesse um inspetor imaginário em sua consciência, fiscalizando, a cada linha da tradução, a segurança jurídica do fazer tradutório. É como se fosse um freio de um carro, acionado ocasionalmente, para evitar que determinadas soluções ou pensamentos mais ousados desestabilizassem a tradução, o que colocaria em risco o seu atrelamento ao respectivo original.

Essa visibilidade está subordinada às normas da instituição fiscalizadora (Junta Comercial do Estado). Por exemplo, ao contrário do que muitas pessoas pensam, o tradutor juramentado não é funcionário público que aufere rendimentos do poder público (ou seja, do Estado ou União). De acordo com o Manual dos Candidatos do Concurso para habilitação de tradutores públicos e intérpretes comerciais (1998, grifo nosso), ele deve atuar como autônomo que exerce um ofício público, conforme abaixo definido:

A investidura no ofício de Tradutor Público e Intérprete Comercial não se trata
de ingresso em cargo ou função pública, nos quadros do Serviço Público, na
qualidade de funcionário público, e recebendo vencimentos do Poder
Público, e sim na qualidade de profissional liberal que exerce um ofício público,
promovendo seu nome, captando clientes, realizando seus trabalhos em
escritório comercial ou na própria residência e recebendo seus honorários, em
conformidade com a tabela de valores e emolumentos, instituída pelas Juntas
Comerciais de seus respectivos Estados em que se encontre matriculado.

Ou seja, não há garantias de trabalho, pois o próprio tradutor deverá captar seus clientes, todavia, poderá fazer uso do status do cargo, promovendo seu nome. O valor cobrado pelos serviços de tradução realizados deverá respeitar a tabela de emolumentos estabelecida por intermédio de deliberações.

Além de observar as normas regulamentares e obrigações estabelecidas pelas referidas deliberações, para que o tradutor público possa trabalhar, deverá providenciar a abertura do livro de traduções perante a Diretoria do Serviço de Fiscalização. Esse procedimento é 
realizado pela apresentação de uma impressão da última folha do livro anterior, a partir da folha 450 até 500, duas cópias do termo de abertura do livro seguinte, para que uma delas seja protocolada pela Diretoria de Fiscalização, acompanhados da capa de requerimento assinada pelo tradutor, que contém seus dados pessoais, número de inscrição e endereço de ofício.

Por conseguinte, os tradutores públicos têm sua visibilidade ressaltada, uma vez que, após protocolada a abertura do livro, a tradução fica registrada nesses livros de tradução a serem mantidos com a devida ordem cronológica e sequencial, conforme determina a deliberação $\mathrm{n}^{\mathrm{o}}$ 04: “No livro 'Registro de Traduções' serão cronologicamente transcritas 'verbum adverbum' sem rasuras nem emendas, e devidamente numeradas, todas as traduções ou versões feitas no mesmo ofício".

E ainda, em seu artigo 10 do Capítulo II - Do Livro de "Registro de Traduções":

\begin{abstract}
Artigo 10 - Os livros "Registro de Traduções" deverão ser mantidos pelos tradutores públicos e intérpretes comerciais sob vigilante guarda e conservação e todos com número de ordem, revestidos das formalidades legais intrínsecas e extrínsecas, previstas nesta Deliberação e no Decreto-lei 486/69, para a emissão de livros, de molde a merecerem a fé pública que a lei lhes confere. (grifo nosso) (cf. nota 17)
\end{abstract}

No referido artigo 10, novamente, é salientada a importância da fé pública como força atuante, não apenas no conteúdo da tradução, mas também em sua forma de registro e manutenção dos livros.

Por fim, todavia, não menos importante, é a característica da visibilidade como interferente, devido à interferência do tradutor público na realidade como um intermediário para a geração de direitos e obrigações através dos documentos traduzidos, a saber:

O trabalho realizado pelo Tradutor Público gera a expedição de um documento legal, para todos os fins, enquanto que o profissional não juramentado executa trabalhos de traduções simples, e de características exclusivamente informais. (Manual do Candidato, 1998:5)

Além das cinco características acima propostas, na tipologia da tradução juramentada, fica também em destaque a visibilidade do tradutor quando da menção de logotipos, brasões de armas, assinaturas e papel timbrado de empresas, bem como da existência de incoerências ou erros no documento original. Diferentemente, na tradução não juramentada ou "simples", 
esses elementos não são mencionados e os erros são passíveis de correção, quer por meio da omissão ou retificação direta, após o contato e verificação com o solicitante do serviço.

Entretanto, a realidade do tradutor público é bem mais complexa, conforme comenta Aubert (2012:13-19) em sua coluna publicada originalmente no boletim Ipsis Litteris de março de 2002 da ATPIESP (Associação Profissional dos Tradutores Públicos e Intérpretes Comerciais do Estado de São Paulo), posteriormente compilada nos Cadernos de Terminologia $\mathrm{n}^{\mathrm{o}} 05$ (2012), sobre possíveis ocorrências de erros nos documentos originais e diversas sugestões de soluções baseadas "no pressuposto - de realização duvidosa, mas real enquanto intencionalidade - de invariança em relação ao original". Ainda citando Aubert (2012:13), a tradução juramentada é:

como se fosse (ou pretendesse ser) uma transparência sobre o original,
servisse como um guia de leitura do original, relatando o que consta do
original - e não o [que] "deveria" ter constado. Assim, em tese, tudo o que
está no original - e somente aquilo que está o original - deveria ser
reproduzido na tradução.

Ou seja, de fato, a função do tradutor é a de transmitir a mensagem efetivamente apresentada no original, tal como está, contendo erros ou não, pois a tentativa de corrigir os erros poderia descaracteriza-lo. A grande dificuldade recai na decisão do tradutor público sobre como tratar e sinalizar as inadequações, erros ou ambiguidades, seja por meio de notas do tradutor (N.T., NdT ou Nota do Tradutor), ou pelo uso do [sic], (sic), o que o torna ainda mais visível. Acima de tudo, o tradutor público busca, por meio das notas, esclarecer ao usuário ou solicitante da tradução que os erros não foram oriundos da prática tradutória, mas que derivam do original. Dentre as várias ocorrências analisadas pelo autor nos aludidos boletins, destacamos, dentre outros, os erros de digitação, ortográficos ou relativos à identificação, como por exemplo nomes próprios e datas (que constituem elementos essenciais do texto principalmente na tradução juramentada), de estrutura gramatical, sintática e léxico.

Nas referidas notas e observações, notam-se diferentes estratégias ou posturas adotadas pelos tradutores públicos, uma vez que "nem tudo - na realidade, quase nada encontra-se regulamentado na prática da tradução juramentada" (Aubert, 2012:5). Os decretos e deliberações que regem o ofício possuem teor genérico e mais burocrático, sem abordar questões de cunho prático e pertinentes ao ato tradutório. $\mathrm{Na}$ maioria dos Estados, os tradutores empossados não recebem treinamento sobre como proceder na tipologia 
juramentada e "há um conjunto de praxes, de hábitos, de tendências e de costumes, alguns mais consensuais, outros menos, ditados quer pelo bom senso, quer pela tradição" (Aubert, 2012:5).

A maior parte de suas decisões são muito provavelmente pautadas nas experiências adquiridas com o tempo de ofício e análises de situações caso a caso, bem como consultas a colegas de ofício sobre como proceder da melhor forma a manter a confiabilidade e segurança jurídica.

Todavia, a Jucemg, Junta Comercial do Estado de Minas Gerais, estabeleceu em seu Anexo I da Resolução RP/07/2012 de 18 de outubro de 2012 um conjunto de instruções e normas de procedimento abrangendo, além das formalidades usuais, o fazer tradutório, organizadas da seguinte forma:

1) Apresentação da tradução juramentada: contém instruções sobre as margens e tamanho do papel, dados do cabeçalho, a menção de signos não verbais (ou seja, brasões, logotipos, chancelas e similares) na forma de nota do tradutor, com a observação para que a apresentação gráfica da tradução seja o mais semelhante possível ao texto do documento original; além da exigência que as páginas da tradução sejam numeradas e unidas de tal forma que, caso essa união seja desfeita, possa deixar marcas visíveis; orienta para que campos não preenchidos sejam assinalados com a expressão "em branco" e, caso a linha na tradução não seja completamente preenchida, o final deverá ser indicado por meio de duas barras (//);

2) Registro da Tradução: instrui sobre onde devem ser inseridos o número da tradução, número do livro e número de páginas para o registro da tradução/versão;

3) Termo de Abertura/Encerramento de uma tradução/versão pública: são apresentados os modelos dos termos de abertura e encerramento da tradução, bem como o procedimento para fornecer segundas vias da tradução em data posterior;

4) Tipos de documentos: contém a explicação sobre os tipos de documentos (original, fotocópia simples, fotocópia autenticada, fax, origem eletrônica) que deverão estar identificados no Termo de Abertura da tradução, além da instrução para impressão de documentos do tipo fax e origem eletrônica; 
5) Integridade e Exatidão: apresenta explicações sobre como proceder nas ocorrências de textos repetidos, por exemplo legendas no verso de documentos, e quais informações não devem ser traduzidas (referências bibliográficas, a menos que solicitado pelo usuário, detalhes de impressão ao final do documento, tais como, a informação "Modelo DOC 060684 impresso pela gráfica xxx" que não deverá ser traduzida). Esse item 5 é o mais extenso do Anexo da Resolução e aborda, dentre outras questões vivenciadas pelos tradutores públicos e intérpretes comerciais na sua práxis tradutória, o procedimento para traduzir partes de peças judiciais, documentos existentes em carta rogatória, situações de texto com duplo sentido e a tradução juramentada a partir de tradução juramentada;

6) Singularidades: como lidar com rasuras, correções manuscritas, erros graves de ortografia em documentos originais, bem como textos ou carimbos em outro idioma para o qual o tradutor não está habilitado. No referido item 6, há inclusive instrução para inserção de nota do tradutor quando houver textos riscados não traduzidos;

7) Designação de autoridades, armas, carimbos, selos e assinaturas: são tratados os casos de como localizar, mencionar e traduzir os carimbos, armas, brasões, lacres, sinetes, chancelas, logotipos e similares, bem como a forma de menção das assinaturas. Ademais, é fornecida a instrução de que todos os carimbos e números de série devem constar da tradução, e que devem ser identificados pelo uso dos colchetes, e que a legalização consular, normalmente em vernáculo, deverá constar no corpo da tradução/versão;

8) Endereços: instrução para que os endereços não sejam traduzidos;

9) Números e Datas: como proceder ao traduzir números do inglês para português, com a alteração da vírgula por ponto, por exemplo, e a utilização das datas no formato brasileiro, no caso de tradução de idioma estrangeiro;

10) Abreviações: contém exemplos de como lidar com abreviações, em geral, traduzidas ou decodificadas quando possível;

11) Erros de ortografia e gramática: determinação do uso de nota do tradutor e do "sic" para assinalar erros grosseiros do texto original; 
12) Históricos escolares e diplomas: é ressaltada a exigência da "máxima fidelidade ao original", não sendo permitida a realização de equivalências de títulos, diplomas pelo tradutor público e intérprete comercial;

13) Nomes próprios e de lugares: aborda inclusive como proceder nos casos de idiomas com alfabeto diferente do latim;

14) Livro de registro de traduções: contém os modelos para o Termo de Abertura e de Encerramento dos livros de registro de traduções, além de explicações sobre o Termo de Ocorrência que permite relatar erros de numeração de página ou repetição de número de tradução;

15) Consularização de documentos: explica a exigência de consularização dos documentos estrangeiros no país de sua emissão para efeito da validade jurídica no Brasil e qual procedimento a ser adotado pelo tradutor público caso o original não contenha essa autenticação; e

16) Documentos em língua portuguesa: explica que documentos de outros países lusófonos não precisam ser traduzidos, porém devem ser autenticados pelos consulados e/ou embaixadas nos países emissores.

Nesse Anexo I da Resolução, também são reforçados os pressupostos de tendência à literalidade e segurança jurídica, respectivamente, na redação do subitem "5.1) A tradução deve ser a mais fiel possível ao texto original, tanto no conteúdo quanto na forma. Deve ser preservada a integridade do documento e mantido o sentido declarativo original." e no preâmbulo do referido Anexo I, conforme abaixo:

Para efeito deste anexo, a sigla TPIC significa Tradutor Público e Intérprete Comercial. O TPIC deve empenhar-se ao máximo para que a tradução/versão seja clara, objetiva, de fácil compreensão, não dando margem à ambiguidade. Deve ainda utilizar materiais e formas, tais como chancelas, selos, dentre outros, de forma a dificultar, ao máximo, a possibilidade de fraudes. 
A íntegra do Anexo I Resolução RP/07/2012 de 18 de outubro de 2012 foi incorporada a esta dissertação de Mestrado na forma do Anexo B.

Isto posto, notamos que a delegação da fé pública implica em grande ônus na atuação do Tradutor Público e Intérprete Comercial, para permitir a validação de atos jurídicos presentes nos documentos apresentados para tradução. Para fazer valer esse poder a ele conferido, esse tradutor se torna visível em benefício do interesse público. A partir dessa relação, pretendemos expor nesta pesquisa como os tradutores atuam sob essas condições de visibilidade imediata, diferenciada, subordinada, registrada e interferente. 


\section{FUNDAMENTAÇÃO TEÓRICA}

\subsection{Reflexões sobre os Modelos Teóricos de Berman, Reiß e Baker}

Conforme evidenciam os Estudos da Tradução em suas diversas matrizes teóricas, de modo geral, toda tradução tem uma finalidade, seja para a difusão do conhecimento, enriquecimento de língua e cultura, intervenção política, religiosa, influenciando, desse modo, nações, grupos específicos, enfim, a vida das pessoas em geral. Com o advento da Internet e maior acesso às informações, a tradução juramentada tornou-se cada vez mais conhecida e presente na vida das pessoas, seja no âmbito acadêmico, pessoal e empresarial, seja nas diversas transações entre pessoas jurídicas. Todavia, ainda há muito a se explorar no âmbito dos estudos sobre a tradução juramentada. Logo, buscamos neste capítulo relacionar diversos modelos consagrados com a tipologia da tradução juramentada. Iremos abordar brevemente os modelos de Antoine Berman, Katharina Rei $\beta$ e Mona Baker quanto a sua aplicabilidade à tradução juramentada.

$\mathrm{O}$ autor do primeiro modelo objeto de nossa reflexão, Antoine Berman, nascido em Argenton-sur-Creuse, em 1942, filósofo, crítico literário e teórico francês da tradução, foi também tradutor de alemão e espanhol. Faleceu em 1991 e é considerado um dos maiores teóricos dos estudos da tradução da França. Escreveu, entre outras obras, L'épreuve de l'étranger. Culture et traduction dans l'Allemagne romantique: Herder, Goethe, Schlegel, Novalis, Humboldt, Schleiermacher, Hölderlin, Gallimard, Essais, em 1984, com o título em português "A prova do estrangeiro: cultura e tradução na Alemanha romântica", traduzido por Maria Emília Pereira Chanut, em 2002; La traduction et la lettre, ou l'auberge du lointain, livro inspirado em seminário que proferiu em 1984, no Collège International de Philosophie, com primeira edição datada de 1985, traduzido para o português com o título "A Tradução e a Letra ou o Albergue do Longínquo", realizada por Marie-Hélène Catherine Torres, Mauri

Furlan e Andreia Guerini, obra que serviu como base para a elaboração desta parte da dissertação. 
Nesse livro, Berman (1985) critica as teorias dominantes na área e as traduções que se prendem ao conteúdo, com pouca ou quase nenhuma consideração pela forma do texto original, que foram apelidadas na época clássica na Europa de "as belas infiéis". Para o estudioso, grande parte das traduções desvia-se da relação com a letra em virtude da preocupação com a captação do sentido.

Berman, na busca pela verdade, pelo lado positivo da tradução, ou seja, da letra do texto enquanto letra, propõe um modelo de análise das tendências deformadoras que operam em toda tradução para "abrir um caminho em direção ao espaço positivo do traduzir e simplesmente do seu próprio" (Berman, 2007:44). Para o autor, as deformações mostram o que não é para ser feito, ou o que deve ser evitado na tradução literária.

Sendo assim, o modelo analítico bermaniano refere-se, portanto, às forças deformadoras que exercem domínio sobre a "prosa literária", e consiste em treze tendências de deformação parafraseadas a seguir (Berman, 2007:48-62):

A Racionalização refere-se às estruturas sintáticas do original, rearranja as frases e sequências de frases na tentativa de arrumá-las conforme uma certa ideia de ordem de um discurso. A prosa (romance, ensaio) tem como característica a estrutura em arborescência (frases longas, repetições, relativas em cascata, frases sem verbo) claramente oposta à linearidade do discurso. A racionalização altera o original de sua arborescência à linearidade. Outra deformação ocorre ao inverter sua tendência de base (a concretude), o que transforma o original do concreto ao abstrato.

A Clarificação acontece a partir da racionalização, mas ao nível de "clareza" sensível das palavras ou de seus sentidos. Parece ser um princípio evidente ou até inerente à tradução, na medida em que o ato de traduzir é explicitante. Todavia, apresenta duas situações diferentes, uma positiva e outra negativa. Ao manifestar algo que não é aparente ou que esteja reprimido no original, revela o poder da tradução de manifestar, elucidar. No sentido negativo, a clarificação pode revelar na tradução o que não se quer no original.

O Alongamento é, de certo modo, fruto das duas primeiras tendências de racionalização e clarificação, pois essas exigem um desdobramento do que está no original, "dobrado". Em geral, toda tradução é tendencialmente mais longa do que o original. 
Entretanto, do ponto de vista do texto, esse alongamento pode coexistir com diversas formas quantitativas de empobrecimento, sendo designado como "vazio". O acréscimo pode não contribuir em nada, apenas aumenta a massa bruta do texto, não colaborando efetivamente na sua significância.

A tendência ao Enobrecimento consiste em uma forma de se produzirem frases elegantes tendo por base, ou matéria-prima, o original. É portanto, somente uma reescritura, um "exercício de estilo" às custas do original. O tradutor vale-se de um vocabulário rebuscado mesmo que esse vocabulário não esteja presente no original. Faz-se presente no campo literário, bem como nas ciências humanas com textos "elevados", "brilhantes", sem considerar o peso de origem em prol do "sentido". O contrário ao Enobrecimento, no tocante às passagens do original consideradas "populares", é o recurso do uso de pseudo-gíria na vulgarização do texto.

No Empobrecimento Qualitativo, ocorre a substituição dos termos, expressões, modos de dizer do original por termos, expressões, modos de dizer, que não possuem a mesma riqueza sonora, tampouco a riqueza significante ou icônica dos primeiros. De certo modo, há uma perda no "colorido" do texto, quando essa prática de substituição (que privilegia a designação às custas da iconicidade) se aplica ao todo de uma obra.

O Empobrecimento Quantitativo significa uma redução de significantes na tradução comparada ao original. Há um desperdício lexical quando, por exemplo, o autor utiliza para um significado uma multiplicidade de significantes, porém, que não são resgatados ou utilizados na tradução. Toda a abundância, a multiplicidade de significantes, considerada importante na prosa, é perdida, e seu tecido lexical é rasgado, empobrecido, pois há menos significantes na tradução.

A Homogeneização consiste na unificação, a não-reprodução do heterogêneo. $\mathrm{O}$ tradutor tende a unificar todos os planos do tecido do original, embora seja originalmente heterogêneo. A Homogeneização engloba a maioria das tendências deformadoras.

Ao se falar em ritmo, logo pensamos na poesia, entretanto, o romance, a carta, os ensaios não são menos rítmicos do que a poesia. Na Destruição dos Ritmos, como o próprio nome revela, há uma quebra, pela tradução, da rítmica textual do original, geralmente, pela 
mudança na pontuação. Nessa deformação, pode ocorrer uma mudança na tonalidade do texto por conta do rompimento do ritmo.

Quando a tradução não transmite o texto subjacente do original, em que determinados significantes chave se correspondem e se encadeiam, ocorre a deformação da Destruição das Redes Significantes Subjacentes. Esse subtexto constitui uma das faces da rítmica e significância da obra. As escolhas do autor de certos verbos, adjetivos e substantivos e não outros caracterizam uma sistemática, em geral, destruída na tradução tradicional.

A Destruição dos Sistematismos Textuais vai além do nível dos significados, pois diz respeito à destruição de frases, construções utilizadas no original. Dentre esses sistematismos, podemos citar o emprego de tempos, bem como o recurso de um determinado tipo de subordinação. Outras formas de deformação anteriormente mencionadas, como a racionalização, a clarificação e o alongamento destroem esse sistema pela introdução de elementos, contribuindo para a miscelânea de tipos de escrituras presente na tradução. Fica reforçado o fato de não ser um "verdadeiro texto" por não ter suas marcas e, sobretudo, as sistematicidades.

A Destruição ou Exotização das Redes de Linguagens Vernaculares ${ }^{21}$ remete ao apagamento dos elementos vernaculares do texto original que, por essência, são mais icônicos, corporais, notadamente presentes em toda grande prosa. Uma tendência dos tradutores para conservar os vernaculares ocorre por meio da exotização, realizada em duas formas: (i) o procedimento tipográfico pelo itálico e (ii) o acréscimo de algo para "sublinhar" o vernacular ou "torná-lo mais verdadeiro", escolhas que podem ocasionar na ridicularização do original. O vernacular não pode ser traduzido a outro vernacular.

A tendência à Destruição das Locuções consiste na destruição de imagens, locuções, provérbios que, quando traduzidos ao amparo da equivalência, as respectivas equivalências de provérbios ou locuções não os substituem e atentam contra a "falância" da obra.

\footnotetext{
${ }^{21}$ Vernacular significa, na rubrica linguagem, que conserva pureza original; sem estrangeirismos; genuíno, puro. In: Dicionário da Língua Portuguesa com Acordo Ortográfico [em linha]. Porto: Porto Editora, 2003-2014. Disponível em: http://www.infopedia.pt/dicionarios/lingua-portuguesa/vernáculo
} 
A última tendência deformadora descrita por Berman (1985) como o Apagamento das Superposições de Línguas refere-se ao caso em que a tradução ameaça a relação de tensão e integração existente entre a língua subjacente e a língua de superfície. Ilustram essa tendência, dentre outros exemplos, as obras de Guimarães Rosa, em que o português clássico e os falares do Nordeste se interpenetram; e o raro caso com sucesso, em uma tradução de Maurice Betz para o francês da Montanha Mágica, de Thomas Mann, em que nos diálogos entre o herói Hans Catorp e sua amada, Madame Chauchat, o tradutor conseguiu manter aparente no francês o alemão de Mann para que se pudesse distinguir e guardar sua estrangeiridade específica.

Isto posto, ao considerarmos as deformações acima descritas em relação à tradução juramentada, mostrou-se complexa a tarefa, uma vez que as classificações foram elaboradas com vistas aos textos literários. Ocorre uma proximidade do modelo de Berman (1985) com a tradução juramentada, quando o autor retoma Schleiemacher (1813) em sua máxima de aproximar o leitor do autor, com a proposta de uma tradução "estrangeirizante". Todavia, no referido modelo, são elencadas questões referentes ao ritmo (destruição dos ritmos), mudança do colorido do texto (empobrecimento quantitativo), a equivalência de provérbios (destruição das locuções), que pouco aparecem como problemática nos textos apresentados para tradução juramentada. Ainda assim, essas questões não invalidariam uma adaptação do modelo caso nossa hipótese de pesquisa fosse a busca pela padronização, de fundo normativo, para tradutores públicos; entretanto, esse não é o nosso objetivo. Uma classificação por meio das deformações opõe-se à necessidade da transparência na tradução juramentada como reforço da segurança jurídica.

A tradução juramentada está sujeita a toda as áreas do conhecimento e categorias de documentos, incluindo também textos literários, por exemplo, em casos de alegação de direitos autorais, peças publicitárias. Porém, a grande maioria de textos apresentados para esse tipo de tradução consiste em textos jurídicos, acadêmicos, documentos pessoais e certidões. Tendo em vista as treze categorias, observamos que poucas poderiam ser aplicadas, dentre elas, a clarificação, o alongamento e, possivelmente, o empobrecimento qualitativo.

Ademais, o fato de um modelo privilegiar o estudo de uma dada tipologia, como a literária, não anularia totalmente a possibilidade de sua aplicação em geral. Por exemplo, o modelo das modalidades de tradução de Aubert $(1984,1998,2006)$ atende à aplicação para 
diversos tipos de texto, mesmo após sua reformulação de 2006, em que priorizou, de certa forma, a tipologia literária. Várias pesquisas foram desenvolvidas nesse sentido, inclusive, com a utilização de uma amostragem variada com cinco tipologias textuais distintas (das áreas literária, jornalista, técnica, jurídica e corporativa) como no trabalho de pós-doutorado de Camargo (1996).

Complementarmente ao acima exposto, a característica analítica do modelo de Berman (1985) afastaria a possibilidade de seu uso em nosso corpus, posto que pretendemos descrever e não realizar uma avaliação ou padronização dos procedimentos tradutórios na tradução juramentada.

O segundo modelo ora abordado é o de Katharina Reiß, linguista alemã e estudiosa da tradução, com diversos trabalhos publicados na área de crítica da tradução; nasceu em 17 de abril de 1923 e, em conjunto com Hans Josef Vermeer e Christiane Nord, é uma representante do funcionalismo alemão ou skopos theorie.

A skopos theorie (skopos, palavra grega que significa propósito ou objetivo) apresentou uma nova perspectiva aos estudos da tradução pelo questionamento de noções como equivalência, a fidelidade ao texto fonte, o que mudou o foco da atenção do texto de partida para o texto de chegada. Essa nova perspectiva defende que a tradução não se resume a uma simples transferência de significado do texto de partida para o texto de chegada. A tradução é considerada um ato de comunicação e a postura do tradutor dependerá do propósito do texto ou função na cultura de chegada.

Logo, um tradutor tomará suas decisões quanto à melhor estratégia de tradução com base nas características predominantes do texto. Segundo Reiß e Vermeer (1996:14), o texto passa a ser definido como uma "oferta informativa" de um produtor para um receptor. Para Reiß (1977/89:113-14), a comunicação é atingida em nível textual, e não apenas nas palavras ou sentenças, devendo, portanto, a equivalência ser alcançada nesse nível.

Munday $(2008: 72)^{22}$ descreve as principais características de cada tipo de texto resumidas por Reiß (1977/89:108-9), conforme o que segue:

\footnotetext{
${ }^{22}$ Referimo-nos ao livro de Jeremy Munday (2008:72-74), em virtude da pouca literatura disponível em língua portuguesa a respeito do trabalho de Katharina Rei $\beta$
} 
1) "Plena comunicação dos fatos": informação, conhecimento, opiniões, etc. A dimensão da língua usada para transmitir a informação é lógica ou referencial, o conteúdo ou "tópico" é o foco principal da comunicação, e o tipo de texto é informativo.

2) "Composição criativa": o autor utiliza a dimensão estética da linguagem. O autor ou “emissor" está em primeiro plano, bem como a forma da mensagem, e o tipo de texto é expressivo.

3) "Indução de respostas comportamentais": o objetivo da função apelativa é apelar ou persuadir o leitor ou " receptor" do texto a atuar de certa maneira. A forma da linguagem é dialógica, o foco é apelativo e Reiß denomina esse tipo de texto de operativo (Munday, 2008:72, tradução nossa). ${ }^{23}$

Em um trabalho datado de 1971, intitulado: Möglichkeiten und Grenzen der Übersetzungskritik: Kategorien und Kriteren für eine sachgerechte Beurteilung von Übersetzungen (traduzido para o inglês por Erroll F. Rhodes como Crítica da Tradução: Os Potenciais e Limitações. Categorias e Critérios para Avaliação da Qualidade da Tradução (tradução nossa). ${ }^{24}$ St. Jerome Publishing Ltd, 2000), segundo Azenha (1999:45, aspas do autor), "Reiß já havia chegado a uma classificação geral para os tipos de texto, a partir da definição não apenas da função de linguagem predominante (já que 'a tradução não é uma operação puramente linguística'), mas também, e sobretudo, da função comunicativa predominante", conforme representado no quadro abaixo:

\footnotetext{
${ }^{23}$ No original: “(1) 'Plain communication of facts': information, knowledge, opinions, etc. The language dimension used to transmit the information is logical or referential, the content or 'topic'is the main focus of the communication, and the text type is informative.

(2) 'Creative composition': the author uses the aesthetic dimension of language. The author or 'sender' is foregrounded, as well as the form of the message, and the text type is expressive.

(3) 'Inducing behavioural responses': the aim of the appelative function is to appeal to or persuade the reader or 'receiver'of the text to act in a certain way. The form of language is dialogic, the focus is appellative and Reiss calls this text type operative."

${ }^{24}$ No original: "Translation Criticism: The Potentials and Limitations. Categories and Criteria for Translation Quality Assessment"
} 


\begin{tabular}{|c|c|c|c|}
\hline Função da Linguagem & representação & expressão & apelo \\
\hline Dimensão da Linguagem & lógica & estética & dialógica \\
\hline Tipo de texto (ênfase) & no conteúdo & na forma & no apelo \\
\hline
\end{tabular}

Quadro 3.1.1 - Classificação geral para os tipos de texto (cf. Azenha,1999:45)

Munday (2008:72) insere, ainda, uma quarta categoria, dos textos de áudio-mídia, exemplificados como filmes e anúncios falados que complementam as outras três funções com imagens visuais, música, etc.

Ainda com base no trabalho de Reiß de 1971, Munday (2008:72) traduziu e adaptou as características funcionais dos tipos de textos relacionados aos métodos de tradução, conforme segue:

\begin{tabular}{|c|c|c|c|}
\hline Tipo de Texto & Informativo & Expressivo & Operativo \\
\hline Função da linguagem & $\begin{array}{l}\text { Informativa (representa } \\
\text { objetos e fatos) }\end{array}$ & $\begin{array}{l}\text { Expressiva } \\
\text { (expressa a atitude do } \\
\text { emissor) }\end{array}$ & $\begin{array}{l}\text { Apelativa } \\
\text { (faz um apelo ao } \\
\text { receptor do texto) }\end{array}$ \\
\hline $\begin{array}{l}\text { Dimensão da } \\
\text { linguagem }\end{array}$ & Lógica & Estética & Dialógica \\
\hline Foco do Texto & no conteúdo & na forma & no apelo \\
\hline $\begin{array}{l}\text { Texto Traduzido } \\
\text { deveria ... }\end{array}$ & $\begin{array}{l}\text { Transmitir conteúdo } \\
\text { referencial }\end{array}$ & Transmitir forma estética & $\begin{array}{l}\text { Instigar a resposta } \\
\text { desejada }\end{array}$ \\
\hline Método de Tradução & $\begin{array}{l}\text { "Prosa simples", } \\
\text { explicitação quando } \\
\text { necessário }\end{array}$ & Método "identificante" & $\begin{array}{l}\text { "Adaptativo", efeito } \\
\text { equivalente }\end{array}$ \\
\hline
\end{tabular}

Quadro 3.1.2 - Características funcionais dos tipos de texto (tradução nossa)

No tocante às duas últimas linhas do quadro acima, que fazem menção aos métodos de tradução, em sua tese de livre-docência publicada em 1976, sob o título Texttyp und Übersetzungsmethode. Der operative Text, Reiß (1976:20) sugere "métodos de tradução específicos de acordo com o tipo de texto" (tradução nossa) ${ }^{25}$, descritos da seguinte forma por Munday (2008:73-74):

\footnotetext{
${ }^{25}$ No original: 'specific translation methods according to text type'
} 
1) $\mathrm{O}$ texto traduzido de um texto informativo deve transmitir o referencial pleno ou o conteúdo conceitual do texto de partida. A tradução deve ser em "prosa simples", sem redundância e com o uso de explicitação quando necessário.

2) O texto traduzido de um texto expressivo deve transmitir a forma artística e estética do texto de partida. A tradução deve utilizar o método "identificante", por meio da adoção pelo tradutor do ponto de vista do autor do texto de partida.

3) O texto traduzido de um texto operativo deve suscitar a resposta desejada no receptor do texto traduzido. A tradução deve empregar o método "adaptativo", que cria um efeito equivalente entre os leitores do texto traduzido.

4) Os textos de áudio-mídia exigem o que Reiß denomina de método "suplementar", ou seja, complementar palavras escritas com música e imagens visuais (Munday, 2008:73-74, tradução nossa). ${ }^{26}$

Reiß (1971:54-88) também lista uma série de critérios de instrução intralinguísticos e extralinguísticos (Instruktionen), por meios das quais pode ser avaliada a adequação de um texto traduzido, a saber:

1) critérios intralinguísticos: características semânticas, lexicais, gramaticais e estilísticas;

2) critérios extralinguísticos: situação, área do assunto, tempo, local, receptor, emissor e “implicações afetivas” (humor, ironia, emoção, etc.) (Munday, 2008:73-74, tradução nossa). ${ }^{27}$

O tipo de texto irá determinar a importância desses critérios, embora estejam interrelacionados (Reiß, 1971:69). Por exemplo, a equivalência semântica deve ser preservada na

\footnotetext{
${ }^{26}$ No original: "(1) The TT of an informative text should transmit the full referential or conceptual content of the ST. The translation should be in 'plain prose', without redundancy and with the use of explicitation when required.

(2) The TT of an expressive text should transmit the aesthetic and artistic form of the ST. The translation should use the 'identifying' method, with the translator adopting the standpoint of the ST author.

(3) The TT of an operative text should produce the desired response in the TT receiver. The translation should employ the 'adaptive' method, creating and equivalent effect among TT readers.

(4) Audio-medial texts require what Reiss calls the 'supplementary' method, supplementing written words with visual images and music."

${ }^{27}$ No original: “(1) intralinguistic criteria: semantic, lexical, grammatical and stylistic features;

(2) extralinguistic criteria: situation, subject field, time, place, receiver, sender and 'affective implications' (humor, irony, emotion, etc.)."
} 
tradução de qualquer texto com foco no conteúdo. Para um texto traduzido que seja uma notícia, os critérios gramaticais poderiam provavelmente vir em segundo lugar; enquanto que, um livro popular de ciências atentaria mais ao estilo individual do texto de partida. Do mesmo modo, Reiß (1971:62), considera "mais importante que uma metáfora seja mantida na tradução de um texto expressivo do que no texto traduzido informativo, em que a tradução de seu valor semântico por si só já será suficiente” (Munday, 2008:74).

Chesterman (1989:105), com base em um folheto (handout) elaborado por Roland Freihoff (sd/sp), exemplificou visualmente as variedades e tipos de texto de Reiß:

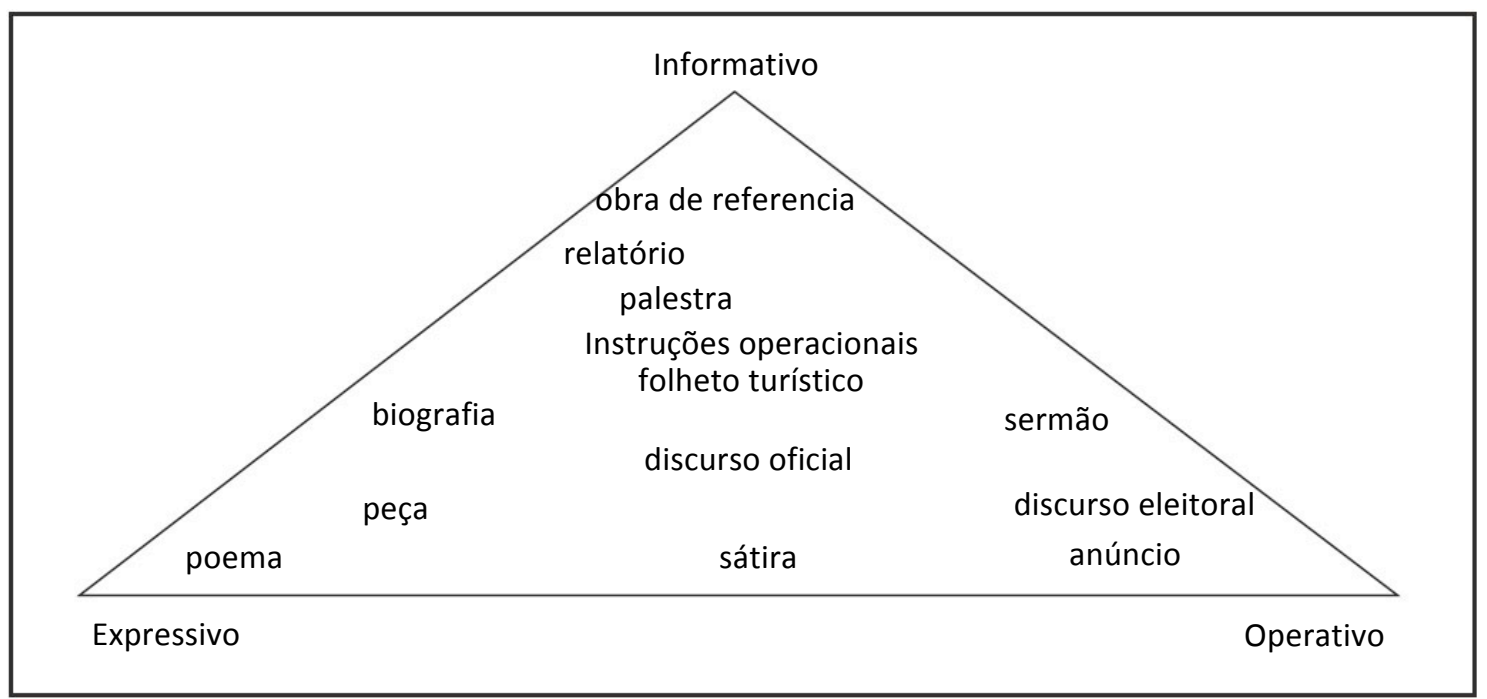

Quadro 3.1.3 - Variedades e tipos de texto segundo o modelo de Reiß (1971)

De acordo com o quadro acima, uma obra de referência é a variedade de texto considerada mais informativa, um poema é altamente expressivo, com foco na forma, e o anúncio de publicidade é, claramente, o tipo de texto operativo (que tentará persuadir alguém a comprar alguma coisa). Entre esses extremos, estão posicionados os tipos híbridos. Desse modo, uma biografia poderia ser classificada entre os tipos informativos e expressivos, uma vez que fornece informações a respeito de um sujeito, ao mesmo tempo em que também exerce, parcialmente, a função expressiva de uma obra literária.

Conforme podemos depreender, o modelo do funcionalismo privilegia o texto de chegada, busca sua função e o resultado. Enquanto que essa teoria provocou uma virada no enfoque, mais prospectivo do que perspectivo, a tipologia da tradução juramentada requer que 
esse olhar continue voltado ao texto de partida. O usuário de tradução juramentada sente-se seguro quanto à sua veracidade e credibilidade, uma vez que o Estado, ao delegar o poder da fé pública, pressupõe a garantia de que o conteúdo do documento será transmitido na íntegra.

Em termos gerais, o funcionalismo também é adequado para aplicação no estudo da tradução juramentada. A conscientização no tocante à função ou propósito do documento são componentes relevantes durante esse ato tradutório específico; porém, a força legal da fé pública atua de forma magnética, atraindo, ao final, a atenção do tradutor para o texto fonte. De todo modo, o conflito vivenciado pelo tradutor público ao ter que, em tese, dizer tudo o que consta no original, ou seja, a exigência de transparência, e a abordagem comunicativa requerida pelas marcas culturais presentes nos diversos documentos a ele apresentados, seria um bom pressuposto para o estudo dos efeitos na cultura de chegada.

Todavia, em nosso corpus de pesquisa, apenas um tipo de documento de partida é utilizado e pretendemos expor o modo como diferentes tradutores atuam sob a influência da fé pública. Nosso foco é observar a visibilidade ocasionada por essa delegação do Estado, que confere credibilidade aos atos do tradutor público no cumprimento de seu ofício. Nesse sentido, a aplicação do modelo funcionalista seria mais apropriada (embora também seja possível o uso de um só tipo de texto para averiguar como cada tradutor aborda a questão do skopo) se o desenho de pesquisa fosse exatamente o contrário: vários documentos traduzidos por um único tradutor. Isso permitiria verificar a postura ou estratégias escolhidas pelo tradutor com relação a diversas tipologias textuais, com base em seus respectivos receptores, emissores, situação, funções, analisadas e comparadas.

Sendo assim, muitos dos critérios extralinguísticos acima mencionados no modelo funcionalista, como situação, área do assunto, tempo, local, receptor, emissor são considerados pelo tradutor na sua prática; porém, a característica da transparência ou clareza torna-se preponderante em relação às demais, tendo em vista o objetivo da segurança jurídica pretendida nesse tipo especial de tradução utilizado nas instituições e órgãos governamentais, bem como nos tribunais. A força da fé pública faz com que o original seja retomado ou balize as decisões e estratégias a serem adotadas pelo tradutor, que se torna visível ao final da tradução, mediante sua assinatura e chancela, comprometendo-se de que foi fiel ao original. 
Por fim, nesta breve reflexão, observamos o modelo de Mona Baker, nascida no Egito em 1953, professora de estudos da tradução e Diretora do Centre for Translation and International Studies na University of Manchester, Inglaterra. Fundou a St. Jerome Publishing da qual é diretora, bem como a revista internacional The Translator. Sua colaboração para os estudos da tradução é extensa, seja por meio de publicações ou obras de referência. A autora demonstra interesse em diversas áreas, tais como: tradução e conflito, o papel da ética na tradução, treinamento, comunidades ativistas na tradução e os estudos baseados em Linguística de Corpus (LC).

Berber Sardinha (2004:3) define a Linguística de Corpus como a área de estudos que trata da "coleta e da exploração de corpora, ou conjunto de dados linguísticos textuais coletados criteriosamente, com o propósito de servirem para a pesquisa de uma língua ou variedade linguística". Ou seja, essa coleta de dados permite trabalhar o texto de uma forma mais concreta, acessando padrões naturais da língua, o que muito contribuiu para os estudos da tradução.

Entretanto, os princípios da LC de exploração da linguagem através de evidências empíricas não são descobertas recentes. Mesmo antes do advento da computação, mainframes e computadores pessoais, já havia corpora, como por exemplo, na Antiguidade, o Corpus Helenístico de Alexandre, o Grande, bem como os corpora de citações bíblicas na Idade Média, conforme menciona Berber Sardinha (2000). Outro exemplo de corpus compilado manualmente foi o SEU (Survey of English Usage) por Randolf Quirk e sua equipe em 1953, em Londres, organizado em fichas de papel, um trabalho monumental sem o uso de computador que deu origem à famosa Comprehensive Grammar of English Language, de Quirk, Greenbaum, Leech e Svartvik.

Nos dias atuais, o tradutor, através da internet, possui acesso a vários corpora compilados em diversos idiomas, o que facilita e contribui significativamente para a busca e confirmação de termos, expressões e forma de uso em linguagem real. O desenvolvimento e a disponibilidade dos corpora eletrônicos foi um salto quântico tal como o computador pessoal foi em relação à máquina de datilografar. Além do Corpus Brown - Brown University Standard Corpus of Present-Day American English, o primeiro corpus linguístico eletrônico lançado em 1964, podemos citar, dentre outros, o BNC - British National Corpus datado de 1995 e, na língua portuguesa, o PORTEXT - corpus proposto por Carlos Maciel ao Institut 
national de la langue française (Inalf), que contém textos do português de Portugal, do Brasil e outros países lusófonos, e o NILC (Núcleo Interinstitucional de Linguística Computacional), que conta hoje com um equipe multidisciplinar de linguistas e cientistas da computação para o processamento de linguagem natural (PLN) para o português (USP São Carlos).

Segundo Baker (1993), a verdadeira virada na história da LC acontecerá "como consequência direta do acesso a grandes corpora de textos originais e traduzidos, e do desenvolvimento de métodos específicos e de ferramentas que permitam investigar esses corpora de modo adequado às necessidades dos pesquisadores da área" (Baker, 1993:235).

Baker destaca, ainda, que "a tarefa mais importante que aguarda a aplicação das técnicas de corpus nos estudos da tradução [...] é a elucidação da natureza do texto traduzido como um evento comunicativo mediado" (Baker, 1993:243). Na tentativa de compreender o que ocorre no processo de tradução, o foco seria a análise do processo de mediação durante a tradução, entre o Código A e B, ou seja, do terceiro código.

No início de 1995, Baker e sua equipe iniciaram a criação de um corpus de tradução composto por textos traduzidos em língua inglesa de diversas línguas de partida e vários domínios. O conceito de corpus utilizado no estudo compreendia “(...) qualquer coleção de textos inteiros (...) em formato eletrônico, analisáveis automaticamente ou semi automaticamente (...)" (Baker, 1995:226). À luz da metodologia baseada em corpus, boa parte das pesquisas, em geral, foram conduzidas da seguinte forma: inicialmente os textos traduzidos (TT) eram disponibilizados em arquivo do Word; em seguida, salvos na extensão .txt, no Bloco de Notas, visto que o software utilizado para processamento dos corpora, WordSmith Tools, criado por Michael Scott, professor da Universidade de Liverpool, Inglaterra e que tem sua versão "demo" (com funções limitadas) disponível para download, apenas processa arquivos em .txt. Em seguida, os textos eram submetidos às ferramentas WordList e Concord do software para posterior análise das estatísticas. O objetivo desse corpus não era fornecer recursos para a lexicografia bilíngue, tampouco exemplos isolados de “translationese" (Baker, 1996:178), ou seja, soluções forçadas de tradução ou "tradutês", mas identificar tipos de comportamento linguístico específicos do texto traduzido. Em outras palavras, o que é gerado pelo processo de mediação durante a tradução. 
Esses padrões ou características pertinentes a textos traduzidos foram denominados traços típicos da tradução, ou seja “(...) traços que ocorrem tipicamente no texto traduzido e não no texto original e que não são resultado da interferência de sistemas linguísticos específicos” (Baker, 1993:243).

Desse modo, por meio da utilização de corpora eletrônicos paralelos ou comparáveis, Baker (1996:180-184), detectou, em conjunto com sua equipe de pesquisadores, certas características ou traços recorrentes que se apresentam comumente nos TTs como: a explicitação, a simplificação, a normatização ou conservadorismo e a estabilização que descreveremos a seguir.

Entende-se por explicitação uma tendência geral para esmiuçar o significado dos termos na tradução, em vez de deixá-los implícitos. Uma forte comprovação dessa tendência consiste no tamanho maior dos textos traduzidos quando comparados ao seu original, influenciado, em parte, pela estrutura morfológica de cada língua. Esse fato, por muito tempo, permaneceu sem ser comprovado empiricamente. Stig Johansson da Universidade de Oslo relatou (1995:2) em seus trabalhos com corpora de norueguês e inglês um aumento, em média, de $10 \%$ no número de palavras das traduções do norueguês para o inglês. Um dado interessante nesse resultado é que também foi observado um aumento na direção inversa para o norueguês.

Outro fenômeno textual comprobatório dessa tendência é obtido na investigação que utiliza, além de corpora de textos de partida e de chegada, corpora de textos traduzidos e originais (no mesmo domínio). A comparação da frequência de palavras tais como "causa", "motivo", "pois", "devido a", e conjunções ou advérbios como "porque", "portanto", "consequentemente" em um corpus de textos originais e textos traduzidos na mesma língua, permitiria confirmar se as traduções utilizam um vocabulário mais explanatório, o que torna, portanto, mais explícitas as relações entre as proposições de um texto.

A simplificação consiste na tendência em tornar o texto mais "fácil" para o leitor. Por exemplo, a fim de auxiliar na compreensão, tradutores evitam manter períodos longos. Um dos recursos comumente empregados é a troca na pontuação da mais fraca para a mais forte, se considerarmos uma classificação em termos de força (vírgula, ponto e vírgula, ponto). Nesse caso, vírgulas tornam-se ponto e vírgula ou ponto final; ponto e vírgula torna-se ponto 
com a finalidade de proporcionar uma leitura mais clara e objetiva. Desse modo, na investigação e comparação de textos traduzidos com textos originais, a incidência de frases mais curtas em textos traduzidos evidenciaria o traço da simplificação. Mudanças sutis na pontuação são difíceis de serem investigadas com base nas técnicas disponíveis de análise de corpus. Todavia, a densidade lexical e razão forma/item (type/token) (Baker, 1995) podem ser facilmente identificáveis.

Uma menor densidade lexical, ou seja, a proporção menor de palavras lexicais em relação a palavras gramaticais, mostra uma redundância, ou tentativa de tornar mais compreensível o texto para o leitor da língua de chegada. A razão forma/item mede a variedade de vocabulário empregado no texto, portanto, quanto menor a faixa, torna-se mais caracterizada a tendência à simplificação ou direcionamento do texto a não-nativos de uma língua.

A tendência para exagerar os traços da língua de chegada e adequar-se aos seus padrões, evidenciada pelo uso de clichês, padrões convencionais ou estruturas gramaticais, pode ser categorizada como exemplo de normalização ou conservacionismo. $O$ status do texto de partida e da língua-alvo irão determinar a força desta tendência, ou seja, quanto maior o status do texto original, menor a tendência à normalização. A normalização é exemplificada por Camargo (2008:5) quando "frases longas e elaboradas bem como elementos redundantes, utilizados nos TOs, são substituídos por colocações menores, e as redundâncias são, muitas vezes, omitidas." Outro exemplo, seria o uso de expressões populares, muito presentes na língua portuguesa, tais como: maria-vai-com-as-outras, joão-sem-braço, maria-gasolina, que se constituem em um grupo convencional do português do Brasil. A tradução de he was a complete nobody pela expressão popular ele era um “joão-ninguém” consiste em uma forma de normalização. Na rubrica do dicionário Caldas Aulete Digital, consta a definição de joãoninguém: s.m. 1. Aquele que é considerado sem valor por não ter instrução, prestígio social, dinheiro; indivíduo insignificante, sem importância; zé-ninguém; pobre-diabo; pé-rapado. ${ }^{28}$

Ao contrário da normalização, que se mostra mais dependente do texto de chegada, a estabilização ou levelling out consiste na tendência a convergir para um meio termo, um centro entre dois extremos. Portanto, esse processo não depende nem da língua-fonte,

\footnotetext{
${ }^{28}$ Disponível em: http://www.aulete.com.br/joão-ninguém
} 
tampouco da língua-alvo. Magalhães (2001:93-103), descreve que na interpretação de conferência, o intérprete tende a usar linguagem oral ao invés de linguagem culta ou viceversa. Das quatro características típicas, Camargo (2008:6) comenta que a estabilização "é a que menos recebeu atenção na literatura da área”.

Baker (1996) em seu texto Estudos da Tradução Baseados em Corpus: os desafios que temos adiante (tradução nossa), ${ }^{29}$ indica uma tendência de estudos futuros mais relacionados com a parte abstrata, noções mais globais, independentes de línguas específicas. Após um início da Linguística de Corpus mais dedicado a questões concretas como listas de frequências e concordâncias, posteriormente a preocupação volta-se para o lado mais abstrato do processo.

Tendo em vista o acima exposto, devemos considerar que a tradução juramentada é entregue e considerada válida somente na forma impressa, portanto, para aplicarmos o modelo de Baker, teríamos que obter os textos em formato eletrônico. É possível de se realizar tal procedimento, mediante conversores de texto, todavia, alguns dos itens essenciais e característicos da tradução juramentada se perderiam nessa conversão, tais como selos, carimbos e assinaturas. Esse fato poderia comprometer a análise desses itens essenciais e marcadores dessa tipologia de tradução.

Outro quesito relevante na aplicação do modelo de Baker refere-se ao tamanho do corpus, que deverá ser significativo para o tratamento de dados por computador. Ao trabalhar com a unidade de tradução, assemelha-se a outros métodos, entretanto em cada modelo essa unidade é redefinida para seus propósitos. Por exemplo, ao compararmos o modelo de Baker (1996) com o de Aubert (2006), ambos lidam com o que denominam unidade de tradução, entretanto, com natureza e objetivos diferentes. Um modelo busca detectar tendências de traços típicos da tradução, que não se fazem presentes em textos originais, e o outro, por sua vez, pretende expor o grau de proximidade ou afastamento da tradução em relação ao seu original. Em termos de tradução juramentada, haveria maior interesse em verificarmos se e como a fé pública interfere nesses "movimentos" de aproximação ou não. Ademais, para a obtenção de tendências, a dimensão do corpus de pesquisa teria que ser ampliada, uma vez

\footnotetext{
${ }^{29}$ No original: "Corpus-based translation studies: the challenges that lie ahead"
} 
que o nosso corpus não foi montado com esse propósito. O referido modelo pode ser utilizado em outras pesquisas sobre tradução juramentada com objetivos diferentes.

A título ilustrativo, extraímos um trecho de um contrato de compra e venda de ações, tipologia textual muito comum dentre os diversos documentos apresentados para tradução juramentada ${ }^{30}$, para a aplicação dos 3 modelos. Solicitamos que o trecho em questão fosse traduzido por dois tradutores colegas da área financeira:

Texto original:

The Company and the Promoter will, to the extent permissible under applicable Laws, not require the Investor to be considered or classified as the 'promoters of the Company' for any reason whatsoever and that to the extent permissible under applicable Laws, the Investor Shares would not be subject to any restriction on Transfer or otherwise (including that of lock-in or other restriction) which are applicable to promoters under any applicable Law.

Texto traduzido pelo Tradutor X:

A Companhia e o Promotor, na medida em que permitido segundo as leis aplicáveis, não exigirão que o Investidor seja considerado ou classificado como os "promotores da Companhia" por qualquer razão que seja, e que as Ações do Investidor não estejam sujeitas a qualquer restrição sobre Transferência ou de outro modo (incluindo a de bloqueio ou outra restrição) que seja aplicável a promotores segundo qualquer lei aplicável.

Texto traduzido pelo Tradutor Y:

A Companhia e o Promotor não irão, na extensão permitida pela lei vigente, requerer que o Investidor seja considerado ou classificado como um dos "promotores da Companhia", por qualquer motivo, seja qual for, e que, na extensão permitida pela lei vigente, as Ações do Investidor não venham a estar sujeitas a qualquer restrição quanto à transferência ou outra (inclusive a de lock-in ou outra restrição) que seja aplicável a promotores nos termos de qualquer lei vigente.

\footnotetext{
${ }^{30}$ Exemplo retirado de nossa prática tradutória.
} 
No texto original acima, o trecho as the 'promoters of the Company' poderia ser traduzido literalmente: como os "promotores da Companhia". O Tradutor X optou por fazer a tradução literal dessa forma citada anteriormente, já o Tradutor Y traduziu: como um dos “promotores da Companhia”. Apesar de sutil, há uma diferença nas escolhas dos tradutores.

À luz do modelo de Baker (1996), a opção do Tradutor Y de traduzir como um dos "promotores da Companhia" poderia ser classificada como explicitação, entretanto, a abordagem nesse modelo é direcionada a mostrar tendências de características do texto traduzido, em geral, e não com um foco específico em relação ao tradutor. Para Berman (1985), essa opção do Tradutor Y seria considerada uma clarificação, pois nota-se a necessidade de deixar claro ou enfatizar que será um dos promotores. Segundo Berman, a clarificação pode ser positiva ou negativa, ao manifestar algo que não é aparente ou que esteja reprimido no original. No exemplo, não seria negativo, pois não há o que não se deva revelar no original. De acordo com o modelo de Rei $\beta$ (1971, 1976), o texto seria considerado do tipo informativo, caso em que o texto traduzido transmitiria o conteúdo referencial pleno ou o conteúdo conceitual do texto de partida. A tradução desse tipo de texto deve ser em "prosa simples", sem redundância e com o uso de explicitação quando necessário. O Tradutor Y pode apresentar uma tendência à explicitação, todavia, conforme discutimos acima, os respectivos modelos possuem abordagens distintas daquela proposta em nossa pesquisa, ou seja, comparar a visibilidade dos tradutores públicos.

Outro exemplo que podemos retirar do texto original acima, seria o termo lock-in. No Dicionário de Termos Financeiros e de Investimento (DOWNES, J e GOODMAN J.E., 1993:280), lock-in significa:

(Bloqueado) 1. Situação em que uma pessoa está impossibilitada de aproveitar as vantagens tributárias na venda de um título ou ativo porque ainda não decorreu o prazo de manutenção do título ou ativo em questão (holding period).

O Tradutor X traduziu lock-in por bloqueio, enquanto que o Tradutor Y optou por manter o termo em inglês, ou seja, lock-in. Não vislumbramos quais classificações recairiam para distinguir as estratégias dos tradutores. No caso do termo lock-in, a aplicação de qualquer dos três modelos não atenderia ao objetivo de comparação e exposição das escolhas dos tradutores. A manutenção do termo em inglês e a tradução literal do respectivo termo indicam 
posturas diferentes, cuja análise e comparação seriam interessantes para o estudo ora proposto.

Portanto, mediante a aplicação dos modelos acima expostos, tais soluções propostas pelos tradutores não seriam facilmente verificadas, não atingiriam um nível de detalhamento necessário para colaborar com nossa pesquisa. O objetivo de expor quão visíveis os tradutores públicos se tornam por conta da delegação da fé pública não seria atingido por intermédio dos referidos modelos.

Desse modo, após nossa reflexão, os exemplos destacados e, considerando as características de nosso corpus, os três modelos apresentados podem ser aplicados no estudo da tradução juramentada, porém, com outros objetivos de pesquisa. As deformações de Berman colaborariam numa tentativa de padronização, de caráter normativo, dos tradutores juramentados; ao passo que Rei $\beta(1971,1976)$ atenderia ao conflito que o tradutor público vivencia entre a necessidade de transparêcia e a abordagem comunicativa em relação aos marcadores culturais; e, por fim, o modelo de Baker (1996) seria aplicado para a busca de tendências dos traços típicos na tradução juramentada. Porém, nosso objetivo é o de mapear as estratégias de tradução e os perfis de diferentes tradutores públicos, e nossa hipótese é que a visibilidade do tradutor torna-se acentuada em virtude da delegação da fé pública a qual, a nosso ver, os modelos acima destacados não se encaixam, a não ser com adaptações. Sendo assim, o modelo que se mostrou mais interessante para a realização desse mapeamento em nosso estudo foi o das modalidades de tradução de Aubert (2006), porque mostra o grau de proximidade ou afastamento da solução tradutória em relação ao documento original, o que nos permite verificar a visibilidade do tradutor. Apresentaremos o referido modelo a seguir.

\subsection{As modalidades de tradução}

Com vistas ao desenvolvimento de uma metodologia de tradução para a formação de tradutores profissionais, Jean-Paul Vinay e Jean Darbelnet (1958) estudaram diferentes métodos ou procedimentos de tradução que, condensaram em sete níveis, cada qual relacionado a um maior grau de complexidade. Esses sete procedimentos foram organizados na forma de escala a partir de um "grau zero" da tradução até o outro extremo, ou seja, o 
procedimento mais distante do texto-fonte. Na prática, podem ser utilizados isolada ou conjuntamente entre si.

Segundo os autores, em geral, os tradutores podem optar por dois métodos de tradução, a saber, a tradução direta ou literal e a tradução oblíqua. Em algumas traduções, pode haver a possibilidade de se transpor a mensagem da língua-fonte, elemento por elemento, para a língua-alvo, devido à existência de (i) categorias paralelas, ou um paralelismo estrutural, ou (ii) conceitos paralelos, que são resultados de paralelismos metalinguísticos. Entretanto, os tradutores podem notar a existência de lacunas na língua-alvo que devam ser preenchidas para que se atinja a mesma impressão geral nas duas mensagens. Nesses casos e quando certos efeitos estilísticos do original não puderem ser transpostos para a língua-alvo, sem afetar a ordem sintática, devem ser utilizados métodos mais complexos, denominados métodos de tradução obliqua.

Esses dois métodos foram subdivididos nos referidos sete procedimentos, em que a tradução direta ficou caracterizada pelo empréstimo, calque e tradução literal, e o método de tradução oblíqua foi subdividido em transposição, modulação, equivalência e adaptação, conforme descritos a seguir.

O procedimento 1, empréstimo, é visto como a forma mais simples de tradução, com o propósito de se preencher uma lacuna, de modo geral, nos casos de novos processos técnicos, tecnologias, conceitos desconhecidos. A decisão de tomar emprestada uma palavra ou expressão da língua-fonte também pode ser utilizada para introduzir um elemento com a cor ou tom da cultura local, o que pode vir a ser uma questão de estilo do tradutor. Muitas vezes, devido ao seu amplo uso, alguns empréstimos são incorporados ao léxico da língua-alvo, não sendo mais considerados empréstimos como, por exemplo, na língua inglesa as palavras francesas menu, chic, hangar, e as expressões déjà vu, enfant terrible e rendez-vous. ${ }^{31}$

O calque, ou procedimento 2, é um tipo especial de empréstimo, por meio do qual uma língua empresta uma forma de expressão a partir de outra, e traduz literalmente cada um dos elementos. O resultado pode ser “(i) um calque lexical, ou seja, que respeita a estrutura sintática da língua-fonte, ao mesmo tempo em que introduz uma nova forma de expressão; por exemplo, o calque do inglês para o francês: Compliments of the Season! - Compliments de la

\footnotetext{
${ }^{31}$ Utilizamos, para ilustrar todos os procedimentos, os exemplos nas línguas inglesa e francesa retirados da tradução do original no capítulo 6 de Vinay (2000:84-93).
} 
saison!; ou (ii) o calque estrutural, que introduz uma nova construção na língua, como no caso do calque do inglês para o francês: Science-fiction - Science-fiction" (Vinay, 2000:85, tradução nossa). ${ }^{32}$ Assim como os empréstimos, após um período de tempo, um calque pode se tornar parte integrante da língua.

No procedimento 3, "tradução literal ou palavra por palavra, ocorre a transferência direta de um texto da língua-fonte em um texto na língua-alvo gramática e idiomaticamente apropriado, caso em que a tarefa do tradutor restringe-se a observar a aderência às servidões linguísticas da língua-fonte" (Vinay, 2000:86, tradução nossa) ${ }^{33}$. Como por exemplo:

\begin{tabular}{l|l}
\hline \hline Where are you? & Où êtes-vous? \\
\hline This train arrives at Union Station at ten. & $\begin{array}{l}\text { Ce train arrive à la gare Centrale à } \\
10 \text { heures. }\end{array}$ \\
\hline \hline
\end{tabular}

Em princípio, a tradução literal revela-se como a única solução passível de reversão e completa em si própria. Mostra-se mais comum entre línguas da mesma família (por exemplo, francês e italiano), principalmente quando há compartilhamento entre as culturas.

Após descritos esses três primeiros procedimentos, se o tradutor concluir que a tradução literal não é adequada, ele deve aplicar os procedimentos do método da tradução oblíqua. Uma tradução literal não é considerada aceitável quando resulta em outro significado, ou não tem nenhum significado, ou é estruturalmente impossível, ou não possui uma expressão correspondente na língua-alvo, ou possui uma expressão correspondente, todavia, não com o mesmo registro.

A título de exemplo:

\begin{tabular}{l|l}
\hline \hline He looked at the map. & Il regarda la carte. \\
He looked the picture of health. & $\begin{array}{l}\text { Il paraissait l'image de la santé. } \\
\text { Il avait l'air en pleine forme. }\end{array}$ \\
\hline \hline
\end{tabular}

\footnotetext{
${ }^{32}$ No original: "i. a lexical caique, as in the first example, below, i.e., a caique which respects the syntactic structure of the TL, whilst introducing a new mode of expression; or ii. a structural caique, as in the second example, below, which introduces a new construction into the language, e.g.:"

${ }^{33}$ No original: "Literal, or word for word, translation is the direct transfer of a SL text into a grammatically and idiomatically appropriate TL text in which the translator's task is limited to observing the adherence to the linguistic servitudes of the TL."
} 
"Ao passo que podemos traduzir literalmente a primeira sentença, isso é impossível na segunda, a menos que o propósito seja expressivo (ou seja, para caracterizar um falante inglês sem muito bom domínio oral da língua francesa). O primeiro par de exemplos é menos específico, uma vez que "carte" é menos específico do que "map". Entretanto, esse fato não invalida o exemplo de forma alguma" (Vinay, 2000:87, tradução nossa). ${ }^{34}$

Já no caso de um tradutor optar por algo similar ao segundo exemplo acima, como Il se portait comme um charme, isso sugere a adoção de uma equivalência das duas mensagens, tendo em vista a posição "neutra" do tradutor que, por estar fora tanto da língua-alvo quanto da língua-fonte, pode fazê-lo. Em última análise, a equivalência de mensagens pode se basear em uma identidade de situações, o que significa dizer que a língua-alvo pode reter certas características da realidade que são desconhecidas na língua-fonte.

A transposição, ou procedimento 4, o primeiro do método de tradução oblíqua, consiste na substituição de uma classe de palavra por outra, sem alterar o significado da mensagem. Além de ser um procedimento especial de tradução, a transposição também pode ocorrer na própria língua. "Por exemplo: 'Il a annoncé qu'il reviendrait', pode ser similarmente expresso, mediante a transposição de um verbo subordinado com um substantivo, ou seja, 'Il a annoncé son retour'. Comparativamente à primeira expressão, denominada expressão base, referimo-nos à segunda como expressão transposta. Na tradução, observamos dois tipos de transposição: (i) obrigatória e (ii) opcional." ${ }^{\text {35 }}$ (Vinay, 2000:88, tradução nossa).

O exemplo a seguir é traduzido literalmente (procedimento 3), porém, pode ser transposto (procedimento 4):

\begin{tabular}{l|l}
\hline \hline Dès son lever... & As soon as he gets $/$ got up... \\
\hline As soon as he gets up... & $\begin{array}{l}\text { Dès son lever... } \\
\text { Dès qu'il se lève... }\end{array}$ \\
\hline \hline
\end{tabular}

\footnotetext{
${ }^{34}$ No original: "While we can translate the first sentence literally, this is impossible for the second, unless we wish to do so for an expressive reason (e.g. in order to characterise and Englishman who does not speak very good conversational French). The first example pair is less expressive, since "carte" is less expressive than "map". But this in no way renders the demonstration invalid."

${ }^{35}$ No original: "For example: 'Il a announcé qu'il reviendrait', can be re-expressed by transposing a subordinate verb with a noun, thus: 'Il a announcé son retour'. In contrast to the first expression, which we call the base expression, we refer to the second one as the transposed expression. In translation there are two distinct types of transposition: (i) obligatory transposition, and (ii) optional transposition."
} 
No exemplo acima, quando traduzido para a língua inglesa, não é possível a escolha entre as duas formas, caso em que somente a forma base é viável. Todavia, quando traduzido para o francês, surgem duas opções entre a aplicação do calque ou uma transposição, por conta da língua francesa permitir ambas as construções.

No procedimento 5, modulação, ocorre uma variação na forma da mensagem, a partir da mudança no ponto de vista. Justifica-se o uso da modulação quando, "embora uma tradução literal ou até mesmo transposição resulte em uma expressão gramaticalmente correta, seja considerada inadequada, não idiomática ou estranha na língua-alvo" "36 (Vinay, 2000:89, tradução nossa). Assim como a transposição, podemos distinguir os tipos livres ou opcionais e fixos ou obrigatórios para o procedimento de modulação. A modulação que altera uma expressão negativa na língua-fonte para uma expressão positiva na língua-alvo é mais frequente do que o tipo não opcional, apesar de estar particularmente relacionada à estrutura de cada língua, como no exemplo:

It is not difficult to show... Il est facile de démontrer...

A modulação livre tende a ser uma solução única, que resulta da linha de pensamento natural e que se mostra mais necessária do que opcional. Sua solução levaria o leitor a exclamar, "Sim, é exatamente o que se diria". Quanto mais for empregada, ou considerada como a única solução, pode vir a se tornar fixa. Entretanto, uma modulação livre não se torna efetivamente fixa até que seja mencionada em dicionários e gramáticas e seja ensinada regularmente.

Na equivalência ou procedimento 6, a mesma situação pode ser descrita por dois textos utilizando métodos estruturais e estilísticos completamente diferentes. "O exemplo clássico de equivalência é dado pela reação de um amador que acidentalmente bate seu dedo com um martelo: se fosse Francês, seu grito de dor seria transcrito por "Aïe!"; porém, se fosse Inglês, isso seria interpretado como "Ouch!". Outros casos notáveis de equivalências são as diversas onomatopeias de sons animais, por exemplo:”37 (Vinay, 2000:90, tradução nossa)

\footnotetext{
${ }^{36}$ No original: "although a literal, or even transposed translation results in a grammatically correct utterance, it is considered unsuitable, unidiomatic or awkward in the TL."

${ }^{37}$ No original: "The classical example of equivalence is given by the reaction of an amateur who accidentally hits his finger with a hammer: if the were French his cry of pain would be transcribed as "Ä̈e!", but if he were English this would be interpreted as "Ouch!". Another striking case of equivalences are the many onomatopoeia of animal sounds, e.g.:"
} 


\begin{tabular}{l|l}
\hline \hline cocorico & cock-a-doodle-do \\
\hline miaou & miaow \\
\hline hi-han & heehaw \\
\hline \hline
\end{tabular}

A maioria das equivalências é fixa e pertence a um repertório fraseológico de expressões idiomáticas, clichês, provérbios, frases nominais ou adjetivas, etc. De modo geral, os provérbios são exemplos perfeitos de equivalências:

\begin{tabular}{l|l}
\hline \hline Il pleut à seaux/des cordes. & It is raining cats and dogs. \\
\hline Like a Bull in a china soup. & Comme um chien dans um jeu de quiles. \\
\hline Too many cooks spoil the broth. & Deux patrons font chavirer la barque. \\
\hline \hline
\end{tabular}

Por último, no sétimo procedimento, a adaptação, atingimos o limite extremo da tradução, que é utilizado nos casos em que o tipo de situação referido pela mensagem na línguafonte é desconhecido na cultura da língua-alvo. "Nesses casos, os tradutores têm que criar uma nova situação que possa ser considerada como equivalente. A adaptação, portanto, pode ser descrita como uma forma especial de equivalência, uma equivalência situacional"38 (Vinay, 2000:91, tradução nossa). É muito comum na tradução de títulos de filmes e livros:

\begin{tabular}{l|l}
\hline \hline Trois hommes et un couffin & Three men and a baby [filme]
\end{tabular}

\begin{tabular}{l|l}
\hline Le grand Meaulnes & The Wanderer [título de livro] \\
\hline
\end{tabular}

Quando há uma interrupção no desenvolvimento das ideias, na forma em que são apresentadas no parágrafo ou na estrutura sintática, nota-se a resistência ou recusa por parte do tradutor em fazer uma adaptação. "Embora os tradutores possam produzir um texto perfeitamente correto sem a adaptação, a sua ausência pode ainda ser percebida por um tom indefinível, algo que não soe muito bem"39 (Vinay, 2000:91, tradução nossa).

Isto posto, salientamos que foi a partir desse conjunto de procedimentos técnicos da tradução, elaborado por Vinay e Darbelnet (1958), que Aubert (1984, 1998, 2006)

\footnotetext{
${ }^{38}$ No original: "In such cases translators have to create a new situation that can be considered as being equivalent. Adaptation can, therefore, be described as a special kind of equivalence, a situational equivalence."

${ }^{39}$ No original: "Even though translators may produce a perfectly correct text without adaptation, the absence of adaptation may still be noticeable by an indefinable tone, something that does not sound quite right."
} 
desenvolveu um modelo, denominado as modalidades de tradução, para fins descritivos, com o intuito de gerar dados quantitativos para posterior análise. O início dessa adaptação e experimentos para a concepção do modelo foi durante uma disciplina, Teoria da Tradução, no curso de especialização em tradução oferecido pela USP, em 1980. Foi utilizado um corpus com o original e as traduções para o alemão, francês e inglês do romance Gabriela, Cravo e Canela, de Jorge Amado. O motivo pelo qual a designação do modelo foi alterada para "modalidades de tradução" foi uma mudança no enfoque, pois "o modelo não mais pretendia descrever procedimentos e sim produtos" (Aubert, 1998:10, grifos do autor).

Durante a revisão do modelo de Vinay e Darbelnet, os maiores desafios do autor, tanto de natureza prática quanto metodológica, estavam relacionados ao tipo de pergunta a ser feita, à definição da unidade textual para a base da quantificação e à reformulação das modalidades, para cumprir seu objetivo de medir o grau de afastamento ou proximidade entre o texto original e o texto traduzido.

Não foi uma tarefa simples, como o próprio autor comenta:

O modelo dos procedimentos técnicos, tal como proposto por Vinay e Darbelnet, teve de ser adaptado às necessidades específicas da análise de córpus. Seria por demais tedioso relatar, aqui, os muitos momentos de ensaio e erro vividos no curso da reformação e redefinição do modelo. Basta, para as necessidades desta apresentação, indicar que, após numerosos experimentos, inclusive as dificuldades impostas por tipologias de texto bastante peculiares, por volta de 1990 um modelo mais definitivo tomou corpo e, com alterações de pouca monta ao logo do período mais recente, desde então tem servido como base para a execução de numerosos projetos específicos de pesquisa. (Aubert, 1998:12)

Dentre as adaptações realizadas, logo de início, houve um deslocamento do "marco zero" do modelo, ou verdadeiro "grau zero" definido por Aubert (1998), como a modalidade de transcrição, e não o empréstimo, anteriormente considerado por Vinay e Darbelnet (1958) como a forma mais simples de tradução.

Notamos uma ampliação nas categorias com a inclusão das modalidades de omissão, transcrição, explicitação/implicitação, tradução intersemiótica, erro, correção e acréscimo. O procedimento de equivalência foi excluído, não por perder importância ou relevância, mas provavelmente por já estar representado nas modalidades de modulação e adaptação, fato que 
pode ser corroborado quando do reagrupamento das modalidades na revisão do modelo em 2006, ao ser designado como uma das três grandes classes de modalidades.

No modelo de 1998, as modalidades também foram agrupadas em dois grandes conjuntos, similarmente aos procedimentos originais de tradução direta ou oblíqua de Vinay e Darbelnet (1958); todavia, nesse caso, denominados tradução direta e tradução indireta, um sinônimo de oblíqua. As modalidades de tradução direta incluem a transcrição, o empréstimo, o decalque, a tradução literal e a transposição. Por sua vez, a explicitação/implicitação, modulação, adaptação e tradução intersemiótica compõem o conjunto das modalidades de tradução indiretas. Os demais tipos não foram inseridos em nenhum dos conjuntos.

Sendo assim, ao compararmos com o modelo original, além das inclusões acima citadas e a exclusão da equivalência, foram mantidas as mesmas denominações nos conjuntos, à exceção do calque que passou a ser designado como decalque. A única modalidade que mudou de grupo foi a transposição que, apesar de ser descrita como a modalidade em que "ocorrem rearranjos morfossintáticos" por Aubert (1998:14), foi incluída no grupo de tradução direta, diversamente da classificação original desse procedimento de tradução, considerado o primeiro dos métodos mais complexos de tradução, denominados de tradução oblíqua.

A título de ilustração, elaboramos a seguir um quadro comparativo da evolução do modelo das modalidades de tradução de Aubert $(1998,2006)$ a partir dos procedimentos técnicos da tradução de Vinay e Darbelnet (1958):

\begin{tabular}{|c|c|c|c|c|c|}
\hline \multicolumn{2}{|c|}{$\begin{array}{c}\text { Vinay e Darbelnet } \\
\text { (1958) Procedimentos } \\
\text { Técnicos da Tradução }\end{array}$} & \multicolumn{2}{|r|}{$\begin{array}{c}\text { Aubert (1998) } \\
\text { Modalidades de Tradução }\end{array}$} & \multicolumn{2}{|c|}{$\begin{array}{c}\text { Aubert (2006) } \\
\text { Modalidades de Tradução Revisadas }\end{array}$} \\
\hline \multirow{3}{*}{ 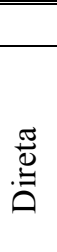 } & \multirow{3}{*}{$\begin{array}{l}\text { Empréstimo } \\
\text { Calque } \\
\text { Tradução Literal }\end{array}$} & & Omissão & \multicolumn{2}{|r|}{ Omissão } \\
\hline & & \multirow{3}{*}{$\stackrel{\frac{\pi}{0}}{\stackrel{0}{0}}$} & \multirow{2}{*}{$\begin{array}{l}\text { Transcrição } \\
\text { Empréstimo } \\
\text { Decalque } \\
\text { Tradução Literal }\end{array}$} & Espelhamento & $\begin{array}{l}\text { Empréstimo } \\
\text { Decalque }\end{array}$ \\
\hline & & & & Literalidade & $\begin{array}{l}\text { Transcrição } \\
\text { Palavra por palavra }\end{array}$ \\
\hline \multirow{2}{*}{$\frac{\stackrel{\sigma}{7}}{\stackrel{\Xi}{0}}$} & \multirow{2}{*}{$\begin{array}{l}\text { Transposição } \\
\text { Modulação } \\
\text { Equivalência } \\
\text { Adaptação }\end{array}$} & & \multirow{2}{*}{$\begin{array}{l}\text { Explicitação/Implicitação } \\
\text { Modulação } \\
\text { Adaptação } \\
\text { Tradução Intersemiótica }\end{array}$} & & $\begin{array}{l}\text { Transposição } \\
\text { Explicitação }\end{array}$ \\
\hline & & 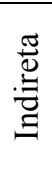 & & Equivalência & $\begin{array}{l}\text { Implicitação } \\
\text { Modulação } \\
\text { Adaptação }\end{array}$ \\
\hline & & & $\begin{array}{l}\text { Erro } \\
\text { Correção } \\
\text { Acréscimo }\end{array}$ & & $\begin{array}{l}\text { Tradução Intersemiótica } \\
\text { Erro }\end{array}$ \\
\hline
\end{tabular}

Quadro 3.2.1 - Evolução do modelo das modalidades de tradução de Aubert (1998, 2006) 
Conforme podemos observar no quadro acima, em 2006, após a revisão do modelo, foi feito um rearranjo das modalidades em três grandes classes: espelhamento, literalidade e equivalência. Essa estruturação das modalidades mais próximas ocorreu por conta do novo enfoque da unidade lexical, que passou a ser observada não apenas em si, mas em relação ao seu co-texto e contexto, com o objetivo de melhor lidar com a linguagem literária.

O conjunto da tradução direta foi desmembrado em duas grandes classes: espelhamento e literalidade. Na classe de espelhamento foram agrupadas as modalidades que não apresentam alterações ou que, se existirem, forem mínimas, incluindo o empréstimo e o decalque. É interessante mencionar que, na definição do modelo reformulado para a modalidade decalque, não é mais mencionada a necessidade de a palavra ou expressão não estar registrada nos principais dicionários da língua fonte.

$\mathrm{Na}$ classe da literalidade, foram reunidas "as soluções tradutórias aparentemente desprovidas de 'ruído' (Aubert, 2006:49), em que, além da transcrição, tradução literal e transposição é incluída a modalidade de explicitação, que antes pertencia ao grupo da tradução indireta. Foi também modificada a designação tradução literal, substituída no modelo revisado por palavra por palavra. A ausência de "ruído" significa a tentativa ou tendência de maior proximidade ao original, ou seja, que a tradução ocorra de uma forma mais direta.

A classe da equivalência engloba as categorias pelas quais, por suas escolhas, o tradutor pode se tornar mais visível ou não. A tradução intersemiótica, modalidade que antes pertencia ao grupo da tradução indireta, não foi incluída nesse novo grande grupo. Houve também a eliminação das modalidades de acréscimo e correção que não pertenciam a nenhum grupo anteriormente.

Similarmente aos procedimentos de Vinay e Darbelnet (1958), as modalidades de tradução podem ser consideradas isoladamente ou em conjunto, ou seja, na forma "híbrida" (Aubert, 1998: 16). Nesse sentido, durante o cotejo, pode-se obter uma combinação de transposição e modulação, ou um empréstimo poderá vir seguido de uma explicitação, dentre outras possibilidades. 
Sendo assim, delineamos a seguir o modelo revisado das modalidades de tradução segundo Aubert (2006:47-56), com alguns exemplos retirados de casos observados em nossa prática profissional. Esse modelo revisto nos pareceu ser o mais apropriado para observarmos o quão visível o tradutor se torna, em virtude de suas escolhas, e foi utilizado por nós na presente pesquisa:

0 - Omissão: "ocorre omissão sempre que um dado segmento textual do texto fonte e a informação nele contida não podem ser recuperados no texto meta. Essa ressalva é de fundamental importância pois, em numerosos casos, embora a correspondência biunívoca seja perdida, a informação como tal é perfeitamente recuperável no texto meta, como nas transposições e nas implicitações" (Aubert, 2006:48, grifos do autor). Ou seja, consideramos omissão quando não forem incluídos segmentos do texto original na tradução, quer por força do próprio original ou por opção do tradutor. Em geral, são utilizadas notas do tradutor para justificar as partes omitidas, seja por estarem em branco ou não serem aplicáveis. Algumas notas são apresentadas de forma genérica e outras mais detalhadamente, com a descrição das partes do documento não traduzidas. Por exemplo: [N.T.: os campos em branco e/ou inaplicáveis não foram traduzidos.]; [Nota do Tradutor: o verso do documento não foi traduzido a pedido verbal da parte interessada. $]^{40}$.

O bom senso e a experiência do tradutor, além de sua análise geral do conteúdo e contexto do documento, oferecerão subsídios para a tomada de decisão quanto à pertinência e real necessidade da tradução de certos conteúdos do documento original, tendo em vista a finalidade da tradução.

Como exemplo de omissão ocasionada pela aplicabilidade/relevância do teor do documento original, temos as informações explicativas, que aparecem no verso das novas certidões de nascimento, casamento e óbito brasileiras emitidas pelos cartórios, sobre o preenchimento dos campos e a composição do número de matrícula.

\footnotetext{
${ }^{40}$ Alguns tradutores utilizam a forma abreviada N.T. e outros por extenso, Nota do Tradutor.
} 


\section{Detalhamento da Matricula}

\begin{tabular}{|c|c|}
\hline Matricula & 0018830155198710003050000053331 \\
\hline Padrão & aaaaaabbcc dddd e ffff ggg hhhhhhh if \\
\hline (1) & Detalhamento \\
\hline aaaaa (00188-3) & Código Nacional da Serventia (identificaçăo única do cartório) \\
\hline bb $(01)$ & $\begin{array}{l}\text { Código do Acervo, sendo: } \\
01 \text { - Acervo Próprio } \\
\text { Outros - Acervos Incorporados }\end{array}$ \\
\hline cc (55) & $\begin{array}{l}\text { Tipo de Serviço Prestado, sendo: } \\
\text { 51: Serviço de Notas } \\
\text { 52: Serviço de Protesto de Títulos } \\
\text { 53: Serviço de Registro de Imóveis } \\
\text { 54: Serviço de Registro de Títulos e Documento Civil de pessoa juridica } \\
\text { 55: Serviço de Registro Civil das Pessoas Naturais } \\
\text { 56: Serviço de Registro de Contratos Maritimos } \\
\text { 57: Registro de Distribuição }\end{array}$ \\
\hline dddd (1987) & Ano do Registro \\
\hline e (1) & $\begin{array}{l}\text { Tipo do livro, sendo: } \\
\text { 1: Livro A (Nascimento) } \\
\text { 2: Livro B (Casamento) } \\
\text { 3: Livro B Auxiliar (Registro de casamento religioso para fins civis) } \\
\text { 4: Livro C (Óbito) } \\
\text { 5: Livro C Auxiliar (Registro de Natimortos) } \\
\text { 6: Livro D (Registro de Proclamas) } \\
\text { 7: Livro E (Demais atos relativos os Registro Civil) }\end{array}$ \\
\hline ffff $(0003)$ & Número do livro \\
\hline$g g g(050)$ & 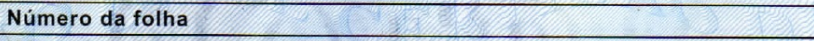 \\
\hline hhhhhhh (0000533) & Número do Termo \\
\hline $\mathrm{ii}(31)$ & Digito Verificador \\
\hline
\end{tabular}

Figura 3.2.1: Verso de certidão de casamento

Essas informações não são relevantes para o destinatário do documento, pois servem apenas como um guia para o preenchimento da certidão, e a sua tradução poderia vir a onerar o valor a ser pago pelo cliente, ou seja, um valor pago para um trecho que não agregará informação ou não será utilizado pelo usuário final da tradução. Outro caso de omissão, a critério do tradutor, pode ser verificado em documentos com extensas listas de sinônimos, em que para se evitar a repetição, ou por falta de sinonímia na língua de chegada, é feita a omissão, tal como no trecho a seguir:

(...) besides any tax, duty, rate, levy, charge, contribution, excise, impost, fees and commissions.

(...) além de qualquer imposto, arrecadação, taxa, tributo, encargo, contribuição, imposto sobre consumo, honorários e comissões. 
No exemplo acima, a palavra impost pode ser traduzida por imposto, taxa ou tributo, opções essas que já aparecem na tradução de termos anteriores. Nesse caso, a omissão se justifica pelo próprio contexto repleto de sinônimos. Algumas omissões podem também ser ocasionadas por conta do cansaço ou falhas no processo de revisão final da tradução, podendo vir a constituir um erro.

1 - Transcrição: "inclui segmentos de texto que pertençam ao acervo de ambas as línguas envolvidas (p.ex. algarismos, fórmulas algébricas e similares) ou, ao contrário, que não pertençam nem à língua fonte nem à língua meta, e sim a uma terceira língua e que, na maioria dos casos, seriam considerados empréstimos no texto fonte (como, por exemplo, frases e aforismos latinos - alea jacta est)" (Aubert, 2006:49). No caso de históricos escolares, material de estudo da pesquisa, é massiva a presença de transcrições de notas, conceitos ou carga horária, seja na forma numérica, seja no sistema de notas por conceitos ou letras (menções A, B, C). Em algumas certidões pessoais, documentos jurídicos e contratuais é observado com frequência o emprego de palavras latinas, tais como:

\begin{tabular}{l|l|l}
\hline \hline \multicolumn{1}{c|}{ Tipo de documento } & \multicolumn{1}{|c}{ Expressão } & \multicolumn{1}{c}{ Tradução } \\
\hline \hline Atestado de óbito & causa mortis & $\begin{array}{l}\text { causa da morte } \\
\text { o falecido, do qual, aquele de cuja } \\
\text { herança se fala }\end{array}$ \\
\hline Jestamentos & pelo feito, na prática \\
\hline Jurídico & $\begin{array}{l}\text { de facto } \\
\text { de jure }\end{array}$ & $\begin{array}{l}\text { a lei é dura, mas é a lei (significa que } \\
\text { a lei deve ser aplicada, não importa o } \\
\text { quanto rigorosa seja) }\end{array}$ \\
\hline Contrato & $\begin{array}{l}\text { mudando o que tem que ser mudado } \\
\text { mutatis } \text { mutandis }\end{array}$ \\
\hline pari passu & simultaneamente \\
\hline bona fide & boa-fé \\
\hline
\end{tabular}

2 - Empréstimo: "trata-se de um segmento textual do texto fonte reproduzido no texto meta com ou sem marcadores específicos de empréstimo (aspas, itálico, negrito, etc.)" (Aubert, 2006:49). Consiste, portanto, na manutenção do termo ou expressão do original na tradução, "um procedimento muito utilizado pelos tradutores em seu trabalho com documentos acadêmicos" (Aubert, Barros e Delvizio, 2010:222), em relação ao nome do aluno, 
estabelecimento de ensino e outros nomes próprios; assim como no caso de razões sociais e nomes de instituições em procurações e contratos. Os endereços são outro exemplo da modalidade de empréstimo, uma vez que, se fossem traduzidos poderiam vir a causar confusão por conta dos diferentes formatos utilizados nos diversos países:

\begin{tabular}{l|l}
\hline \hline Endereço brasileiro: & $\begin{array}{l}\text { Avenida Paulista, n²1230, Jardim Palmeiras } \\
\text { CEP: 12345-678, São José do Rio Preto, SP }\end{array}$ \\
\hline Endereço de Brasília: & $\begin{array}{l}\text { SES - Avenida das Nações, Qd 807, Lt 27. CEP } \\
70417-900 \text { Brasília- DF. }\end{array}$ \\
\hline Endereço americano: & $\begin{array}{l}123 \text { First Ave } \\
\text { Baltimore, MD 21223-012 } \\
\text { USA }\end{array}$ \\
\hline \hline
\end{tabular}

No sistema de endereçamento postal dos correios brasileiros, o logradouro (rua, avenida, praça, estrada, rodovia, dentre outros) é descrito logo no início, diferente da ordem de outros países, em que o número antecede essa informação, como no exemplo do endereço americano apresentado no quadro acima. Até mesmo, no próprio país, pode haver diferença na forma de designação do endereço, como no caso da capital brasileira, Brasília, com o uso de siglas: SQN (Super Quadra Norte), QL (Quadra do Lago), SAUS (Setor de Autarquias Sul) etc., que fazem parte de endereços de casas, comércios e órgãos públicos.

Outros exemplos de empréstimos seriam as unidades monetárias (pounds, cents, yen), palavras do universo financeiro, por exemplo, segundo o Dicionário de Termos de Negócios Pinho (1997:207, 257 e 267), caps que significa juros máximos ou limite superior e floors, juros mínimos, hedging como proteção contra riscos de mercado, cobertura contra um risco potencial. Na maior parte das vezes, os usuários de tradução dessas áreas financeiras preferem a manutenção do termo original em língua inglesa, ou seja, o empréstimo.

3- Decalque: "uma palavra ou expressão emprestada da língua fonte mas que foi submetida a certas adaptações gráficas e/ou morfológicas para conformar-se às convenções da língua alvo" (Aubert, 2006:49). Trata-se do aportuguesamento de palavras estrangeiras, ou seja, a inserção de um empréstimo no sistema fonológico, grafológico e morfológico da língua de chegada, nesse caso, a língua portuguesa. Podemos ilustrar essa modalidade com as palavras contêiner, 
sênior, leiaute, escan, originárias de container, senior, layout, scan, respectivamente. Há também casos de eliminação do acento gráfico como em lágrimas por lagrimas e José por Jose, no caso de versões da língua portuguesa para outra língua estrangeira. Muitos vocábulos já foram dicionarizados, tais como, beisebol (base-ball), líder (leader), futebol (football), contribuindo para a modernização da língua.

4 - Tradução palavra por palavra: essa modalidade "ocorre sempre que, na comparação entre os segmentos textuais fonte e meta, se observa: (i) o mesmo número de palavras, (ii) na mesma ordem sintática, (iii) empregando as 'mesmas' categorias gramaticais e (iv) contendo as opções lexicais que, no contexto específico, podem ser tidas por sendo sinônimos interlinguais" (Aubert, 2006:50). Destacamos, para ilustrar, inicialmente um trecho de um contrato social e, em seguida, trecho das definições de um contrato:

\begin{tabular}{c|c|c|c|c|c|c}
\hline \hline The & capital & shall & be & divided & into & shares \\
\hline $\mathrm{O}$ & capital & deverá & ser & dividido & em & ações \\
\hline \hline
\end{tabular}

\begin{tabular}{|c|c|c|c|c|c|}
\hline Disbursement - & has & the & meaning & described & below \\
\hline Desembolso - & tem & 0 & significado & descrito & abaixo \\
\hline
\end{tabular}

Notamos que as quatro exigências acima descritas para a ocorrência de tradução palavra por palavra estão presentes nos referidos exemplos. Anteriormente, essa modalidade era designada tradução literal que, poderia ser interpretada como "ao pé da letra", ou inadequada, fato que, conforme pode-se perceber não implica em "inadequação, erro ou compreensão falha" (Aubert, 1987:19-20); o que ocorre é uma "coincidência" na ordem sintática e classe gramatical.

5 - Transposição: “ocorre transposição sempre que um ou mais dos critérios formais para a definição de tradução palavra por palavra deixa de ser satisfeito, ou seja, sempre que ocorrerem rearranjos morfossintáticos” (Aubert, 2006:50, grifos do autor). As diferenças 
morfossintáticas entre o português e inglês tornam algumas transposições obrigatórias, tais como a necessidade de inversões em:

\begin{tabular}{r|l}
\hline \hline Project description - & descrição do projeto \\
Credit rights - & direitos creditórios \\
Early death - & falecimento prematuro \\
\hline \hline
\end{tabular}

Há casos em que uma ou mais palavras são condensadas em uma só:

\begin{aligned} & \hline \hline build out - benfeitoria \\ & a company in good standing - uma empresa idônea \\ & event of default - Inadimplemento, inadimplência ${ }^{41} \\ &$\hline Interim balance sheet - balancete \\ & \hline \hline\end{aligned}

Ou uma palavra se desdobrar em várias, como os seguintes advérbios muito frequentes em contratos e documentos jurídicos:

\begin{tabular}{l|l}
\hline \hline Hereunder - & nos termos deste instrumento ou de acordo com o presente Contrato \\
\hline Hereby - & pelo presente, por meio deste \\
\hline Hereinafter - & daqui por diante \\
\hline Herein - & neste ato, neste instrumento \\
\hline Theretofore - & antes disso, até então \\
\hline Whereby- & pelo qual \\
\hline \hline
\end{tabular}

${ }^{41}$ Embora o termo inadimplência pareça mais comum, na terminologia contratual é mais utilizada a sinomímia inadimplemento. Conforme busca no google para inadimplemento contratual (339.000) versus inadimplência contratual (164.000). 
Nos demais casos, existem também as transposições facultativas, que ficam a critério do tradutor e que podem, de certo modo, imprimir sua "assinatura" ou "representam parcela significativa da manifestação, no plano linguístico, da liberdade do tradutor" (Aubert, 1998:14), ou seu perfil em relação ao texto traduzido, ao optar preferivelmente pelo uso dessa modalidade. Por exemplo, o trecho em inglês I arrived late pode ser traduzido por Eu cheguei tarde (tradução palavra por palavra) ou Cheguei tarde (transposição).

6 - Explicitação: "tentativa de assegurar a literalidade semântica, mediante o recurso a construções parafrásticas de diversos tipos, que podem assumir diversas formas: aposto explicativo, nota de rodapé ou de fim, glossário final, e outros recursos (mesmo um prefácio ou posfácio podem exercer o papel de ferramenta de explicitação)” (Aubert, 2006:50). Nos casos de siglas, principalmente quando muito específicas ou marcadas culturalmente, a explicitação permite o pleno entendimento por parte do receptor do produto tradução. No Brasil, há várias siglas utilizadas para fins de identificação tanto de pessoas físicas quanto jurídicas, como o RG (Registro Geral) e o CPF (Cadastro de Pessoas Físicas) para pessoas físicas, e o CNPJ (Cadastro Nacional da Pessoa Jurídica) e o NIRE (Número de Identificação do Registro de Empresas), que significa o registro de legalidade de uma empresa na Junta Comercial do Estado para pessoas jurídicas, sem mencionar a miríade de siglas referentes aos impostos (PIS, COFINS, ICMS, IPI).

Em alguns históricos de ensino médio dos Estados Unidos e Canadá podem constar disciplinas ou programas diferentes daqueles existentes no Brasil, como por exemplo o advanced placement, que consiste na possibilidade de o aluno com boas notas nos exames obter créditos durante o ensino médio, que poderão se utilizados na universidade. Na tipologia da tradução juramentada, de modo geral, os tradutores optam por fazer um empréstimo seguido da explicitação da sigla ou termo culturalmente marcado:

\begin{tabular}{l|l}
\hline \hline PAP CHEMISTRY - & $\begin{array}{l}\text { QUímiCA PAP (PRE-ADVANCED PLACEMENT - curso especial para } \\
\text { obtenção de crédito universitário) }\end{array}$ \\
\hline \hline
\end{tabular}

Observa-se também uma tendência à manutenção de leis na forma de empréstimo, seguidas da explicação, tendo em vista a não equivalência dos sistemas jurídicos dos países 
envolvidos na tradução. A The UK Bribery Act e a US Foreign Corrupt Practices Act 1977 $(F C P A)$, leis contra a prática de suborno e corrupção são citadas com bastante frequência em cláusulas contratuais. Até mesmo entre elas há várias diferenças, apesar de abordarem a mesma questão. O procedimento ou estratégia adotada pelo tradutor de realizar um empréstimo combinado com a explicitação permite que seja feita uma posterior consulta para pesquisa ou esclarecimento, com base no nome original da referida lei ou regulamento, o que não ocorreria se o tradutor tivesse optado pela tradução palavra por palavra, por exemplo.

7- Implicitação: "Formalmente, é o reverso da explicitação, em que informações explícitas contidas no texto fonte e identificáveis com determinado segmento textual, tornam-se referências implícitas" (Aubert, 2006:51). Na tipologia de documento escolar, por conta do uso de quadros ou tabelas de notas, o espaço das linhas e colunas muitas vezes pode se tornar um limitador para o trabalho do tradutor, ocasionando uma tendência ao uso dessa modalidade, como por exemplo em: Língua Portuguesa por Portuguese Lang. e Carga Horária por apenas C.H. em vez de Class Hours.

Em documentos contratuais, podemos exemplificar a implicitação na tradução do título da cláusula Autonomia das disposições contratuais para o inglês como Severability, cláusula essa que estabelece a continuidade da validade e eficácia das demais disposições contratuais, caso alguma disposição torne-se inválida ou inexequível. Outro caso de implicitação pode-se verificar na parte das Considerações ou Consideranda, no preâmbulo da maioria dos contratos que, geralmente em língua inglesa aparece com o uso repetido da conjunção whereas, conforme exemplo abaixo:

(i) Whereas Seller is a lawful owner of (i) one billion, ten million, eight hundred and ninety-five thousand, three hundred $(1,010,895,300)$ shares issued by the Company;

(ii) Whereas Purchaser desires to purchase from Seller the Equity Interests, and Seller is willing to sell such Equity Interests to Purchaser;

(iii) Whereas all terms and conditions necessary to enter into this Agreement have been negotiated and agreed upon to the satisfactory manner by the Parties; and

(iv) Whereas according to this Agreement, the Parties intend to agree upon the terms and conditions for the acquisition of the Equity Interests by Purchaser; 


\section{CONSIDERAÇÕES}

(i) A Vendedora é a legítima proprietária de (i) um bilhão, dez milhões, oitocentos e noventa e cinco mil, trezentas (1.010.895.300) ações emitidas pela Sociedade;

(ii) A Compradora deseja adquirir da Vendedora as Participações Acionárias, e a Vendedora está disposta a vender as referidas Participações Acionárias à Compradora;

(iii) Todos os termos e condições necessários para a celebração deste Contrato foram negociados e acordados de forma satisfatória pelas Partes; e

(iv) Em conformidade com este Contrato, as Partes pretendem estipular os termos e condições para a aquisição das Participações Acionárias pela Compradora; (tradução nossa)

O tradutor ao optar por traduzir a palavra Whereas como o título Considerações, o mantém implícito em cada item seguinte. Essa estratégia evita a repetição da fraseologia Considerando que no início das declarações constantes no preâmbulo.

8 - Modulação: "Esta é provavelmente a modalidade de tradução mais rica de facetas e, por isso mesmo, mais complexa de se caracterizar (Salkie, 2001). Confunde-se, em grande medida, com a idiomaticidade das línguas e, no plano do discurso literário, mostra-se como a principal marca identificadora da tradução literária, em especial no contraste com a tradução técnica (Taillefer, 2004; Corrêa, 1998; Camargo, 1993; Zanotto, 1993)" (Aubert, 2006:52). A riqueza dessa modalidade deve-se ao fato de se mostrar em diversas formas, e ocorre sempre que o sentido ou efeito, em geral, for mantido, porém representado por significados total ou parcialmente distintos. "A modulação revela que o tradutor se sentiu à vontade para utilizar esse recurso criativo na tradução, buscando, com mudanças no ponto de vista, conferir maior clareza e fluência ao texto de chegada" (Camargo \& Validório, 2005:1.352 apud Aubert, Barros e Delvizio, 2010:225) ${ }^{42}$. A intenção de facilitar a leitura por meio da referida

\footnotetext{
${ }^{42}$ CAMARGO, D. C. Uma análise de semelhanças e diferenças na tradução de textos técnicos, jornalísticos e literários. Delta, São Paulo, v.20, n.1, jun. 2004. Disponível em: <http://www.scielo.br/scielo. php?script=sci_arttext\&pid=S0102-44502004000100001\&lng=en\& nrm=iso $>$.

VALIDÓRIO, V. C. Um estudo da tradução de termos culturalmente marcados em O Sumiço da Santa: The War of The Saints e Mar Morto: Sea of Death, de Jorge Amado, traduzidas por Gregory Rabassa. Estudos Linguísticos, Campinas, v.34, p.1.349-54, 2005.
} 
criatividade pode se manifestar nas modulações optativas pois, assim como as transposições, as modulações podem ser obrigatórias ou facultativas. Sendo assim, principalmente nos textos literários, uma dada mensagem é compreendida por intermédio de outro colorido cultural; entretanto, também se faz presente em documentos pragmáticos, conforme os exemplos abaixo:

\begin{tabular}{l|l}
\hline \hline \multicolumn{1}{c|}{ Ocorrência direta } & \multicolumn{1}{c}{ Ocorrência de Modulação } \\
\hline \hline For the avoidance of doubt - para evitar dúvidas & para fins de esclarecimento \\
\hline $\begin{array}{l}\text { Including, but without limitation - incluindo, mas } \\
\text { sem limitação }\end{array}$ & incluindo, entre outros \\
\hline provided however that - ficando ressalvado que & sendo certo que, \\
\hline \hline
\end{tabular}

9 - Adaptação: “a principal característica da adaptação reside em ser uma intersecção de sentidos, mesmo denotativos, abandonando a busca da equivalência plena” (Aubert, 2006:53). A solução tradutória adotada nessa modalidade atinge quase que o limite extremo da tradução, por questões culturais, de necessidade de assimilação ou pela ausência de equivalente na cultura de chegada. Conforme descrevem Aubert, Barros e Delvizio (2010:226), "o nível escolar denominado High School (EUA), por exemplo, não possui as mesmas subdivisões, séries e conteúdo do Ensino Médio ou $2^{\circ}$ grau (Brasil), no entanto, se tivéssemos de equiparar os dois sistemas escolares, eles estariam no mesmo nível em relação à idade escolar e função social e acadêmica." Ainda, segundo Aubert (1984:75), esse é um procedimento que representa "uma tentativa de não mais assegurar uma tentativa de equivalência [perfeita], mas apenas certo grau de semelhança entre as duas situações, cada qual privativa de um dos complexos socioculturais em confronto". A transparência requerida em tradução juramentada provavelmente conduz a uma tendência para que não ocorra a adaptação.

Todavia, na tradução de documentos societários e atos constitutivos de empresas são adaptados termos em virtude das diferenças nas estruturas organizacionais existentes: 


\begin{tabular}{l|l}
\hline \hline Board of directors - & Conselho de Administração \\
\hline Directors - & Conselheiros \\
\hline Officers - & Diretores ou Administradores, dependendo \\
& do tipo societário (Sociedade Anônima, \\
& Sociedade de Responsabilidade Limitada) \\
\hline Articles of Incorporation - & Contrato Social, Atos Constitutivos \\
\hline By-Laws & Estatuto Social \\
\hline \hline
\end{tabular}

As leis, regulamentos, sistemas jurídicos e estruturas corporativas diferem de país para país, e o tradutor por meio de pesquisas e conhecimento da área envolvida, faz-se valer da modalidade de adaptação nessas situações extremas. Dentre os exemplos acima citados, as soluções tradutórias para Articles of Incorporation e By-laws podem ser encontradas, acompanhadas da respectiva explicação, mediante consulta ao Dicionário de Termos Financeiros e de Investimento (DOWNES, J e GOODMAN J.E, 1993:24):

\begin{abstract}
ARTICLES OF INCORPORATION (Instrumento de constituição da sociedade). Documento registrado em um estado dos EUA pelos fundadores de uma companhia. Depois de aprovar o instrumento, o estado expede um certificado; os dois documentos constituem o documento de constituição (CHARTER), que autoriza a existência legal da sociedade. $\mathrm{O}$ documento de constituição contém informações como razão social, objetivo, número de ações autorizadas e o número e identidade dos diretores. Os poderes da sociedade, portanto, originam-se da legislação do estado e das disposições do documento de constituição. Os regulamentos internos da companhia são estabelecidos no estatuto social (BYLAWS) elaborado pelos fundadores.
\end{abstract}

No Brasil, são comumente utilizados tanto a tradução mais geral, por Atos Constitutivos, como a mais específica, ou seja, o Contrato Social para as sociedades empresárias (antigas sociedades de responsabilidades limitadas no Brasil) e o Estatuto Social para as Sociedades Anônimas, conforme esses termos são designados na legislação brasileira.

10 - Erro: "incluem-se na categoria erro tão somente os casos que ultrapassam os limites da adaptação, resultando em troca injustificada de sentidos" (Aubert, 2006:55, grifo do autor).

Segundo o mesmo autor, há de se distinguir dois tipos de erros quanto à competência linguística ou domínio das técnicas tradutórias: 
os erros semânticos (de conteúdo), bem como os erro formais (ortográficos e morfossintáticos), podem ser conceituados como erros NA tradução (originárias de falhas de competência ou de desempenho linguístico), mas, não propriamente como erros DE tradução (originados de falhas no domínio das técnicas tradutórias propriamente ditas). (Aubert, 1984:82)

Poderíamos acrescentar outro exemplo de erro ocasionado por "ruídos" no original (falta de coerência ou coesão, erros gramaticais) que, dependendo da situação, teriam que ser mantidos pelo tradutor, que optaria, nesse caso, por uma tradução mais literal. Se o documento original apresentar diversos erros ou inconsistências, como por exemplo, uma carta manuscrita de um presidiário juntada aos autos de um processo criminal, redigida em idioma estrangeiro e que, após tradução, faria parte de um laudo psiquiátrico, nesse caso em especial, a postura adotada pelo tradutor seria determinante. Se o tradutor optasse por rearranjar os "erros" gramaticais ou de coerência textual presentes, poderia vir a interferir no diagnóstico e na decisão final do referido processo judicial.

11 - Tradução Intersemiótica: "ocorre quando itens como figuras, logos, selos e outros são traduzidos textualmente" (cf. Aubert, 1998:138). Uma das características da tradução juramentada é a grande presença desses itens emblemáticos e que devem ser traduzidos ou mencionados.

Nascimento (2006:47 e 118, respectivamente) define itens semióticos como signos não verbais encontrados nos textos de partida, que devem ser traduzidos em signos verbais nos textos de chegada e, ainda identificou três posturas em relação a esses itens: menção, descrição ou reprodução. No primeiro caso, menciona-se, entre colchetes, a existência do item: [coat of arms], [illegible signature]. No segundo, descreve-se o item: [Stamp of the Secretary of State at the top of the front page of the document.]. No terceiro caso, o tradutor copia o item do texto de partida e o insere na tradução. Na época do uso da máquina de datilografar, esse último procedimento não era possível, porém, com o advento do computador, tornou-se viável tal reprodução.

Portanto, embora o modelo redefinido em 2006, acima descrito e exemplificado, tenha sido utilizado mais frequentemente em pesquisas de textos literários, propomos que continue a ser aplicado no estudo da tradução juramentada. Em nosso escopo de pesquisa, à luz das modalidades de tradução, buscamos dar enfoque à descrição das estratégias escolhidas pelos tradutores que atuam com um componente a mais: a delegação da fé pública. 


\section{MATERIAL DE ESTUDO E METODOLOGIA}

\subsection{Apresentação do material}

O corpus da pesquisa consiste em traduções de um mesmo documento original realizadas por doze tradutores públicos escolhidos aleatoriamente, sendo seis nomeados no concurso de 1978 realizado pela Junta Comercial do Estado de São Paulo (segundo concurso, tendo sido o primeiro realizado no ano de 1956) e seis nomeados em 1998, o mais recente. A seleção dos dois grupos foi facilitada pela consulta do número de matrícula na lista de tradutores públicos disponível no site da Jucesp ${ }^{43}$, uma vez que os tradutores públicos nomeados no concurso mais recente possuem numeração acima de 500 .

Simulamos a necessidade da tradução de um histórico escolar do ensino médio para futuros estudos no exterior, pela contratação de fato dos serviços de 12 tradutores juramentados. Para preservar o caráter científico e a imparcialidade na coleta dos dados, solicitamos que um terceiro atuasse como cliente das 12 traduções juramentadas, evitando, desse modo, qualquer interferência na elaboração do produto final. Sendo assim, de posse dos contatos, o cliente da pesquisa, que também era o titular do histórico (fato que garantiu ainda mais veracidade na simulação), forneceu a mesma instrução a todos os tradutores. Solicitou a tradução do português para o inglês de seu histórico escolar, com o objetivo de realizar um curso no Canadá. A coleta das traduções foi realizada no mês de julho de 2013.

Essa tipologia textual de documento escolar foi selecionada, tendo em vista sua grande frequência requerida em tradução juramentada, devido ao crescente intercâmbio acadêmicocultural entre Brasil, Inglaterra, Canadá, Estados Unidos e demais países de língua inglesa. Nessa mesma linha de pesquisa, foi realizado um trabalho semelhante para o idioma francês por Alves (2005), que inspirou a metodologia de coleta de dados desta pesquisa.

Considerando que nosso objetivo não é o de cotejar as traduções para fins avaliativos, e por questões éticas, foram mantidos em caráter sigiloso os nomes dos respectivos tradutores selecionados aleatoriamente, os quais receberam uma designação numérica: Tradutor 1, Tradutor

\footnotetext{
${ }^{43} \mathrm{O}$ endereço do site da Jucesp para consulta da lista de tradutores públicos do Estado de São Paulo é: http://www.jucesp.fazenda.sp.gov.br/leiloeiros_tradutores.php
} 
2 e assim consecutivamente. O primeiro grupo, constituído do Tradutor 1 ao 6 , foi composto por pessoas nomeadas no concurso de 1978, e o segundo grupo, do Tradutor 7 ao 12, nomeados no concurso de 1998. Todos receberam uma cópia autenticada do mesmo histórico do ensino médio, em português brasileiro, que serviu como texto de partida. O terceiro, atuando como cliente, inclusive coletou dados quanto ao atendimento recebido e eventuais esclarecimentos fornecidos ou não pelos tradutores, como uma forma de observar o cumprimento do papel social do tradutor público. Todavia, esses dados são complementares e mencionaremos, a título de curiosidade, nos resultados, visto que não são objeto de estudo nesta pesquisa.

\subsection{Metodologia}

No desenvolvimento do trabalho de pesquisa, procedemos, em um primeiro momento, à elaboração de uma lista para melhor organização dos dados. Cada linha ou item do documento original foi destacado em numeração sequencial, na forma de subtítulo, seguida das 12 traduções realizadas pelos respectivos tradutores públicos para o item em questão. Sendo assim, nessa primeira parte, possibilitamos obter um panorama da flutuação nas soluções tradutórias. Complementarmente, foi realizada a comparação dos elementos não verbais e extra-tradutórios. Esses elementos não pertencentes ao texto, porém determinantes da tipologia juramentada, consistem, dentre outros, na disposição do cabeçalho da folha timbrada do tradutor, no conteúdo do Intróito (introdução ou parágrafo de abertura da tradução, em geral contendo o nome e identificação do tradutor público), e no Fecho (encerramento que indica não haver mais texto a ser traduzido, acompanhado da expressão “dou fé", local e data). ${ }^{44}$

Para tanto, a disposição dos itens destacados do histórico em português para o primeiro levantamento de dados foi realizada da seguinte forma:

1. Governo do Estado de São Paulo

2. Secretaria de Estado da Educação

3. Coordenadoria de Ensino

4. Da Região Metropolitana da Grande São Paulo

5. Delegacia de Ensino "Prof. Carlos Humberto Volpom” (S.C.S)

6. Escola Estadual "Maria Trujilo Torloni"

\footnotetext{
${ }^{44}$ Os referidos itens estão estabelecidos na Deliberação n⿳o 04 de 01 de dezembro de 2000, que rege o ofício de Tradutor Público.
} 
7. Endereço: Estrada das Lágrimas, 579 - Bairro São José - Cep. 09581-300 - São Caetano do Sul - São Paulo

8. Ato de Criação da Escola: Lei no 7986 , de 30/09/65

9. Histórico Escolar

10. $2^{\circ} \mathrm{Grau}$

11. Registro de Matrícula (RM) do Aluno

12. Dados do Aluno

13. Nome do Aluno

14. Nascimento

15. Localidade

16. Estado

17. Nacionalidade - Brasil.

18. Dia Mês Ano - 241081

19. Deixa de constar a filiação do(a) aluno(a),

20. conforme RES. SE-12,

21. publicada em 13/06/95,

22. que homologa a Deliberação CEE № 04/95.

23. Resultados dos Estudos Realizados no $2^{\circ} \mathrm{Grau}$

24. Curso

25. Inciso III

26. do art. $7^{\circ}$

27. da Del. CEE 29/82

28. Ato de Autorização

29. Res. SE 345-DOE 10/12/84

30. Matérias

31. Componentes Curriculares

32. Menções ou Notas

33. Carga Horária

34. Parte Comum

35. RES. CFE 06/86

36. Núcleo Comum

37. Português

38. Língua Port. e Literatura

39. $1^{\mathrm{a}} \quad 2^{\mathrm{a}} \quad 3^{\mathrm{a}}$

40. Total

41. Estudos Sociais

42. História

43. Geografia

44. Ciências

45. Física

46. Química

47. Biologia e Prog. de Saúde

48. Matemática

49. Língua Estrangeira Moderna (Inglês)

50. Art. $7^{\circ}$ da Lei 5692/71

51. Educação Física

52. Educação Artística

53. Educação Moral e Cívica

54. Parte Comum - total da carga horária

55. Parte Diversificada 
56. Filosofia

57. Sociologia

58. L.E.M. (Inglês)

59. Parte Diversificada - total da carga horária

60. Carga Horária Total do Curso

61. Ensino Religioso - NF

62. Total de Horas do Estágio Supervisionado

63. Estudos Realizados

64. Curso Anterior $-1^{\circ}$ Grau

65. Ano de Conclusão

66. Estabelecimento

67. Município

68. Estado

69. 1995

70. EEPSG Prof ${ }^{\frac{a}{-}}$ Eurydice Zerbini

71. São Paulo - SP

72. No $2^{\circ}$ Grau

73. Série

74. Ano

75. Estabelecimento

76. Município

77. Estado

78. $1^{\text {a }}-1996$

79. EEPSG Maria Trujilo Torloni

80. S.C. Sul - SP

81. $2^{\mathrm{a}}-1997$

82. EEPSG Maria Trujilo Torloni

83. S.C. Sul - SP

84. $3^{\mathrm{a}}-1998$

85. EE. Maria Trujilo Torloni

86. S.C. Sul - SP

87. Transferência durante o período letivo

88. Rendimento escolar do aluno

89. no ano letivo de

90. até de

91. Classe

92. Turno

93. Grau

94. Série

95. Turma

96. $\mathrm{N}^{\mathrm{o}}$ de chamada

97. Componentes Curriculares

98. Menções ou Notas

99. $1^{\circ} \mathrm{Bim}$

100. $2^{\circ} \mathrm{Bim}$

101. $3^{\circ} \mathrm{Bim}$

102. $4^{\circ} \mathrm{Bim}$

103. Faltas

104. Aulas Dadas

105. Dependência 
106. Parte Comum

107. Língua Portuguesa e Literatura

108. História

109. Geografia

110. Física

111. Química

112. Biologia e Programas de Saúde

113. Matemática

114. Língua Estrang. Moderna (

115. Educação Física

116. Educação Artística

117. Educação Moral e Cívica

118. Parte Diversificada

119. Ensino Religioso

120. F ( ) NF ( )

121. Estágio Supervisionado (Carga Horária)

122. Observações

123. 1. Os asteriscos indicam que a promoção do aluno,

124. nos respectivos componentes curriculares,

125. decorre apenas de apuração da assiduidade.

126. 2. Ensino Religioso

127. $\mathrm{F}=$ Freqüentou

128. NF = Não Freqüentou

129. Este documento não contém emendas nem rasuras

130. CN: FLS LIVRO:

131. MUNICÍPIO: UF:

132. Menções - Conceitos

133. Excelente

134. Bom

135. Satisfatório

136. Sofrível

137. Insatisfatório

138. Certificado

139. O Diretor da Escola Estadual "Maria Trujilo Torloni"

140. de acordo com o Artigo 16 da Lei 5692/71,

141. Certifica que,

142. Vivian Xavier Orosco

143. RG 26.220.812-X

144. concluiu o/a

145. $3^{\text {a }}$ série do Ens. Médio

146. no ano letivo de 1998 ,

147. estando apto ao prosseguimento de estudos em nível Superior.

148. 22/04/99

149. Data

150. Resolução $\mathrm{SE} \mathrm{N}^{\mathrm{o}} 25 / 81-\operatorname{artigo} 3^{\circ}, \S 4^{\circ}$

151. Para uso da escola receptora

152. em caso de matrícula no $2^{\circ}$ grau

153. ou no Ensino Superior.

154. DOE Suplemento

155. $\mathrm{N}^{\mathrm{O}}$ / Data / Caderno / Página 
156. Observações

157. Assinatura

158. Wilson's Computer - $7610-3104$

Cada item acima foi inserido na tabela apresentada abaixo, seguido das doze versões para o inglês propostas pelos tradutores. Os grupos representativos das duas gerações de tradutores foram destacados para facilitar a visualização do grau de dispersão:

Item do texto de partida

\begin{tabular}{lll}
\hline & Tradutor 1 \\
Grupo & Tradutor 2 \\
1978 & Tradutor 3 \\
& Tradutor 4 \\
& Tradutor 5 \\
& Tradutor 6 \\
\hline & Tradutor 7 \\
Grupo & Tradutor 8 \\
1998 & Tradutor 9 \\
& Tradutor 10 \\
& Tradutor 11 \\
& Tradutor 12
\end{tabular}

No Apêndice desta dissertação, consta o levantamento das doze versões para os referidos 158 itens destacados do documento original. O corpus foi dessa forma organizado com o objetivo de facilitar a exposição das tendências dos tradutores.

Em um segundo momento, realizamos a classificação dos dados em unidades lexicais e posterior tabulação dos resultados, com base no modelo das modalidades de tradução de Aubert (2006). O texto de partida continha 605 palavras que foram cotejadas com as doze traduções, o que totalizou uma classificação de 7.260 unidades lexicais. Portanto, o modelo aubertiano foi aplicado em nosso corpus paralelo de um original e suas 12 traduções, na forma descrita mais detalhadamente por Aubert (2006, p.48):

A ocorrência das modalidades é observada ao longo dos textos (original e tradução), considerando-se cada palavra tal como empregada no texto fonte e tal como reproduzida ou resgatada, lexicalmente ou não, no texto meta. Assim, a cada unidade lexical do texto fonte será necessário indagar qual o seu equivalente no texto meta, o que exige efetuar uma análise extremamente precisa, observando, a um só tempo, a unidade lexical em si e o seu co-texto e contexto de ocorrência, e, para tanto, dispor de um instrumento capaz de designar e identificar a grande variedade de fenômenos linguístico-estilísticos que podem tornar-se visíveis no processo de cotejo. 
Sendo assim, as unidades lexicais isoladas foram colididas com as traduções e classificadas segundo as modalidades de tradução (0 - omissão, 1- transcrição, 2- empréstimo, 3- decalque, 4- tradução literal ou palavra por palavra, 5- transposição, 6- explicitação, 7implicitação, 8-modulação, 9-adaptação, 10-erro e 11-tradução intersemiótica). A contagem foi feita com base no documento original e, nos casos de itens híbridos (com mais de uma classificação), consideramos a classificação de maior valor. Na sequência, foi realizada a quantificação estatística dos dados apresentada em duas tabelas (Grupo de 1978 e de 1998), da seguinte forma:

\begin{tabular}{|c|c|c|c|}
\hline \multicolumn{2}{|c|}{ Modalidade } & \multicolumn{2}{|c|}{ Tradutor } \\
\hline Código & Nome & $\mathbf{N}$ & $\%$ \\
\hline 0 & Omissão & & \\
\hline 1 & Transcrição & & \\
\hline 2 & Empréstimo & & \\
\hline 3 & Decalque & & \\
\hline 4 & Pal. por Pal. & & \\
\hline 5 & Transposição & & \\
\hline 6 & Explicitação & & \\
\hline 7 & Implicitação & & \\
\hline 8 & Modulação & & \\
\hline 9 & Adaptação & & \\
\hline 10 & Erro & & \\
\hline 11 & Trad. Intersemiótica & & \\
\hline & Total & 605 & 100 \\
\hline
\end{tabular}

Tabela 4.2.1 - Modelo da tabela para apresentação dos dados estatísticos, segundo as modalidades de tradução (intitulada: Distribuição das Modalidades de Tradução para Tradutores Habilitados em (ano)).

Abaixo, apresentamos alguns exemplos da classificação realizada de acordo com o modelo das modalidades de tradução de Aubert (2006), sendo que, na eventualidade de duas classificações para a mesma unidade lexical, chamadas modalidades híbridas, a contagem será feita pela modalidade mais distante:

\begin{tabular}{|l|l|l|}
\hline \multicolumn{1}{|c|}{ unidade lexical do original } & \multicolumn{1}{c|}{ tradução resgatada } & \multicolumn{1}{c|}{ modalidade de tradução } \\
\hline Cep & - & {$[0]$ omissão } \\
\hline 98 & 98 & {$[1]$ transcrição } \\
\hline DOE & DOE & {$[2]$ empréstimo } \\
\hline (Endereço-Estrada das) Lágrimas & (Estrada das) Lagrimas & {$[3]$ decalque } \\
\hline Geografia & Geography & {$[4]$ palavra por palavra } \\
\hline (estágio) supervisionado & supervised (apprenticeship) & {$[5]$ transposição } \\
\hline DOE & State Official Gazette & {$[6]$ explicitação } \\
\hline RG & RG [Identity Card] & {$[2+6]$ explicitação $=[6]$} \\
\hline EEPSG & EPSG & {$[10]$ erro } \\
\hline
\end{tabular}


Portanto, realizamos duas compilações de dados: a primeira para obter um panorama da flutuação nas soluções tradutórias (apresentada no Apêndice), e a segunda para a classificação segundo o modelo aubertiano das modalidades de tradução, por meio de unidades lexicais. Os resultados obtidos serão descritos mais detalhadamente no capítulo seguinte. 


\section{ANÁLISES}

A partir da metodologia descrita no capítulo anterior, obtivemos o seguinte resultado estatístico, conforme as tabelas abaixo:

\begin{tabular}{|c|c|c|c|c|c|c|c|c|c|c|c|c|c|c|c|}
\hline \multicolumn{2}{|c|}{ Modalidade } & \multicolumn{2}{|c|}{ Tradutor 1} & \multicolumn{2}{|c|}{ Tradutor 2} & \multicolumn{2}{|c|}{ Tradutor 3} & \multicolumn{2}{|c|}{ Tradutor 4} & \multicolumn{2}{|c|}{ Tradutor 5} & \multicolumn{2}{|c|}{ Tradutor 6} & \multicolumn{2}{|c|}{ Total Geral } \\
\hline Código & Nome & $\mathbf{N}$ & $\%$ & $\mathbf{N}$ & $\%$ & $\mathbf{N}$ & $\%$ & $\mathbf{N}$ & $\%$ & $\mathbf{N}$ & $\%$ & $\mathbf{N}$ & $\%$ & $\mathbf{N}$ & $\%$ \\
\hline 0 & Omissão & 152 & 25,12 & 155 & 25,61 & 86 & 14,21 & 264 & 43,63 & 33 & 5,45 & 116 & 19,17 & 806 & 22,20 \\
\hline 1 & Transcrição & 112 & 18,51 & 118 & 19,50 & 117 & 19,33 & 94 & 15,53 & 120 & 19,83 & 119 & 19,66 & 680 & 18,73 \\
\hline 2 & Empréstimo & 47 & 7,76 & 64 & 10,57 & 64 & 10,57 & 59 & 9,75 & 72 & 11,90 & 77 & 12,72 & 383 & 10,55 \\
\hline 3 & Decalque & 0 & 0 & 0 & 0 & 0 & 0 & 0 & 0 & 0 & 0 & 0 & 0 & 0 & 0 \\
\hline 4 & Pal. por Pal. & 108 & 17,85 & 130 & 21,48 & 161 & 26,61 & 93 & 15,37 & 190 & 31,40 & 147 & 24,29 & 829 & 22,83 \\
\hline 5 & Transposição & 85 & 14,04 & 79 & 13,05 & 93 & 15,37 & 43 & 7,10 & 123 & 20,33 & 85 & 14,04 & 508 & 13,99 \\
\hline 6 & Explicitação & 42 & 6,94 & 27 & 4,46 & 32 & 5,28 & 17 & 2,80 & 7 & 1,15 & 22 & 3,63 & 147 & 4,04 \\
\hline 7 & Implicitação & 8 & 1,32 & 2 & 0,33 & 8 & 1,32 & 2 & 0,33 & 5 & 0,82 & 2 & 0,33 & 27 & 0,74 \\
\hline 8 & Modulação & 38 & 6,28 & 18 & 2,97 & 31 & 5,12 & 21 & 3,47 & 44 & 7,27 & 31 & 5,12 & 183 & 5,04 \\
\hline 9 & Adaptação & 0 & 0 & 0 & 0 & 0 & 0 & 0 & 0 & 0 & 0 & 0 & 0 & 0 & 0 \\
\hline 10 & Erro & 1 & 0,16 & 1 & 0,16 & & 0,16 & 8 & 1,32 & & 0,49 & 1 & 0,16 & 15 & 0,41 \\
\hline 11 & $\begin{array}{c}\text { Trad. } \\
\text { itersemiótica }\end{array}$ & 12 & 1,98 & 11 & 1,81 & 12 & 1,98 & 4 & 0,66 & 8 & 1,32 & 5 & 0,82 & 52 & 1,43 \\
\hline & Total & 605 & 100 & 605 & 100 & 605 & 100 & 605 & 100 & 605 & 100 & 605 & 100 & 3.630 & 100 \\
\hline
\end{tabular}

Tabela 5.1 - Distribuição das Modalidades de Tradução para Tradutores Habilitados em 1978

\begin{tabular}{|c|c|c|c|c|c|c|c|c|c|c|c|c|c|c|c|}
\hline \multicolumn{2}{|c|}{ Modalidade } & \multicolumn{2}{|c|}{ Tradutor 7} & \multicolumn{2}{|c|}{ Tradutor 8} & \multicolumn{2}{|c|}{ Tradutor 9} & \multicolumn{2}{|c|}{ Tradutor 10} & \multicolumn{2}{|c|}{ Tradutor 11} & \multicolumn{2}{|c|}{\begin{tabular}{|l|} 
Tradutor 12 \\
\end{tabular}} & \multicolumn{2}{|c|}{ Total Geral } \\
\hline Código & Nome & $\mathbf{N}$ & $\%$ & \begin{tabular}{|l|}
$\mathbf{N}$ \\
\end{tabular} & $\%$ & $\mathbf{N}$ & $\%$ & \begin{tabular}{|l|}
$\mathbf{N}$ \\
\end{tabular} & $\%$ & \begin{tabular}{|l|}
$\mathbf{N}$ \\
\end{tabular} & $\%$ & \begin{tabular}{|l|}
$\mathbf{N}$ \\
\end{tabular} & $\%$ & $\mathbf{N}$ & $\%$ \\
\hline 0 & Omissão & 14 & 2,31 & 96 & 15,87 & 190 & 31,40 & 138 & 22,80 & 136 & 22,47 & 181 & 29,91 & 755 & 20,79 \\
\hline 1 & Transcrição & 126 & 20,82 & 121 & 20 & 106 & 17,52 & 125 & 20,66 & 118 & 19,50 & 113 & 18,67 & 709 & 19,53 \\
\hline 2 & Empréstimo & 63 & 10,41 & 76 & 12,56 & 79 & 13,05 & 78 & 12,90 & 74 & 12,23 & 76 & 12,56 & 446 & 12,28 \\
\hline 3 & Decalque & 0 & 0 & 0 & 0 & 0 & 0 & 2 & 0 & 0 & 0 & 0 & 0 & 2 & 0,05 \\
\hline 4 & Pal. por Pal. & 191 & 31,57 & 167 & 27,60 & 121 & 20 & 126 & 20,82 & 139 & 22,97 & 136 & 22,47 & 880 & 24,24 \\
\hline 5 & Transposição & 126 & 20,82 & 93 & 15,37 & 66 & 10,90 & 73 & 12,06 & 80 & 13,22 & 62 & 10,24 & 500 & 13,77 \\
\hline 6 & Explicitação & 45 & 7,43 & 11 & 1,81 & 7 & 1,16 & 14 & 2,31 & 11 & 1,81 & 3 & 0,49 & 91 & 2,50 \\
\hline 7 & Implicitação & 3 & 0,49 & 4 & 0,66 & 4 & 0,66 & 7 & 1,16 & 7 & 1,16 & 2 & 0,33 & 27 & 0,74 \\
\hline 8 & Modulação & 26 & 4,29 & 26 & 4,30 & 17 & 2,80 & 33 & 5,45 & 19 & 3,14 & 15 & 2,47 & 136 & 3,74 \\
\hline 9 & Adaptação & 0 & 0 & 0 & 0 & 0 & 0 & 0 & 0 & 0 & 0 & 0 & 0 & 0 & 0 \\
\hline 10 & Erro & 5 & 0,82 & 2 & 0,33 & 5 & 0,82 & 2 & 0,33 & 13 & 2,15 & 10 & 1,65 & 37 & 1,02 \\
\hline 11 & $\begin{array}{c}\text { Trad. } \\
\text { Intersemiótica }\end{array}$ & 6 & 0,99 & 9 & 1,49 & 10 & 1,65 & 7 & 1,16 & 8 & 1,32 & 7 & 1,16 & 47 & 1,29 \\
\hline & Total & 605 & 100 & 605 & 100 & 605 & 100 & 605 & 100 & 605 & 100 & 605 & 100 & 3.630 & 100 \\
\hline
\end{tabular}

Tabela 5.2 - Distribuição das Modalidades de Tradução para Tradutores Habilitados em 1998

Com base nesses dados, realizamos a descrição dos perfis de cada tradutor, levando em consideração os resultados estatísticos obtidos e demais características pertinentes à tradução juramentada. Em seguida, apresentamos o panorama geral dos grupos e o comparativo entre as duas gerações de tradutores do corpus de pesquisa.

\subsection{Perfil das duas gerações de tradutores}

Este capítulo tem por finalidade traçar um panorama das tendências individuais dos tradutores em um primeiro momento e, em seguida, descrever as características de cada geração, comparando-as ao final. Para tanto, após a análise dos dados coletados referentes aos 
12 tradutores, elaboramos uma ficha descritiva do perfil para cada tradutor, a fim de facilitar a apresentação dos resultados. Cada ficha descritiva do perfil iniciará com o gráfico contendo os valores estatísticos da distribuição das modalidades para o tradutor em questão. Em seguida, são descritos os detalhes sobre a apresentação da tradução consistindo dos itens de a) até k), que irão abordar desde o papel timbrado até o fecho e assinatura do tradutor. Após a aparência geral do documento impresso, foram destacados itens de grande visibilidade, a saber, a tradução intersemiótica e as notas do tradutor. Por fim, é realizado um resumo sobre a tendência do perfil do tradutor. Sendo assim, descrevemos a seguir o que foi verificado em cada um desses itens:

Gráfico: os gráficos apresentados em cada ficha descritiva de tradutor foram elaborados a partir das informações contidas nas Tabelas 5.1 e 5.2 referentes à Distribuição das Modalidades de Tradução para Tradutores Habilitados em 1978 e 1998, respectivamente.

\section{Apresentação da tradução - Aparência geral do documento impresso:}

Em um primeiro momento, a análise da aparência da tradução pode parecer secundária. Entretanto, se considerarmos o propósito de transmissão eficaz das informações, a referida apresentação pode tanto facilitar ou prejudicar a leitura e compreensão do teor por parte do cliente direto (solicitante), ou usuário final da tradução (funcionários de repartições públicas, juízes, secretários de registros e matrículas em escolas e universidades). Nesse item, em especial, o foco da observação foi o cumprimento das instruções estabelecidas na deliberação Jucesp número 04 de $1^{\circ}$ de novembro de 2000, que rege o ofício de tradutor público e intérprete comercial. Para cada tradução, verificamos:

a) Papel timbrado do tradutor contém as informações completas exigidas pela deliberação do ofício - o artigo 12 da deliberação Jucesp 04/2000 determina que:

Todas as traduções ou versões serão lavradas no livro "Registro de Traduções", das quais constarão, obrigatoriamente: a) o nome completo do tradutor público e intérprete comercial; b) o número de sua matrícula na Junta Comercial do Estado de São Paulo; c) o idioma; d) o número de inscrição no C.P.F. - Cadastro de Pessoas Físicas, do Ministério da Fazenda; e) o número de ordem da tradução ou versão feita, com menção do número de ordem do Livro "Registro de Traduções" e das respectivas folhas em que foram lavradas; f) a identificação do documento traduzido ou vertido; g) o valor dos emolumentos cobrados e o número e série do recibo respectivo; h) data e assinatura do tradutor público e intérprete comercial. 
Todavia, por ocasião da posse, constava no site da Jucesp, em 17 de novembro de 2000, a seguinte orientação:

\section{O Tradutor Público e Intérprete Comercial empossado deverá:}

2. Providenciar a confecção de modelo de papel timbrado, em duas vias, que deverão ser entregues à Jucesp, para aprovação prévia. Este papel timbrado será utilizado na execução dos serviços de tradução e versão, devendo conter: a) nome completo; b) endereço completo do tradutor; c) número de matrícula na Jucesp; d) número de documento de identidade (RG); e) número de inscrição no Cadastro de Pessoas Físicas do Ministério da Fazenda (CPF); f) número de inscrição no Cadastro de Contribuinte Mobiliário (C.C.M.); g) idioma(s) no(s) qual(is) o tradutor está matriculado. A utilização do brasão da República Federativa no Brasil no impresso é facultativa.

Essa duplicidade de instruções ocasionou comportamentos diversos na elaboração do papel timbrado, conforme observaremos adiante, em cada ficha descritiva dos tradutores.

b) Uso do Brasão da República Federativa do Brasil - conforme o parágrafo $1^{\circ}$ do artigo 13 da deliberação número 04: “É facultado aos tradutores públicos e intérpretes comerciais inscreverem nos impressos para o exercício de seu ofício, o brasão da república e a referência à República Federativa do Brasil, observada a legislação pertinente”.

c) Cor do papel e impressão - não há nenhuma instrução por parte da Junta quanto à gramatura, ou cor do papel, porém observamos também essa característica

d) Uso de marca d'água - não há nenhuma instrução por parte da Junta quanto ao uso de marca d'água, porém observamos também essa característica

e) Número de tradução, livro e folhas para composição do livro - conforme determina o artigo $8^{\circ}$ da deliberação: "No livro 'Registro de Traduções' serão cronologicamente transcritas 'verbum adverbum', sem rasuras nem emendas, e devidamente numeradas, todas as traduções e versões feitas no mesmo ofício." O item e) do artigo 12 também faz alusão a essa obrigatoriedade: “e) o número de ordem da tradução ou versão feita, com menção do número de ordem do Livro 'Registro de Traduções' e das respectivas folhas em que foram lavradas".

f) Introito geral ou específico - Por ocasião da posse dos tradutores públicos e intérpretes comerciais aprovados no concurso de 1998, no período de inscrições e início do exercício do ofício, permaneceu afixado na Diretoria do Serviço de Fiscalização da Secretaria de Desenvolvimento Econômico, Ciência, Tecnologia e Inovação da Junta Comercial do Estado 
de São Paulo (Jucesp) o modelo para o introito e o fecho dos tradutores públicos. Para o cabeçalho da tradução, constava o seguinte:

Tradução $\mathrm{N}^{\mathrm{o}}$ : $\quad$ Livro $\mathrm{N}^{\mathrm{o}}$ : $\quad$ Folha $\mathrm{N}^{\mathrm{o}}$ :

CERTIFICO E DOU FÉ para os devidos fins que, nesta data me foi apresentado um documento no idioma , o qual traduzo para o vernáculo no seguinte teor:

g) Corpo do texto - observamos se o tradutor utilizou o formado retrato ou paisagem, bem como o tamanho e tipo de letra e alinhamento. É de praxe na área a utilização da letra Times New Roman tamanho 12, e nas tabelas um número mínimo entre 6 ou 7, de forma que possa estar legível.

Antes do surgimento do computador, as traduções realizadas em máquinas datilográficas tinham uma aparência carregada ou até mesmo "poluída", dificultando a leitura, ou tornando-a cansativa, devido ao excesso de tracejados para anular campos em branco. Também eram utilizados como uma forma de assegurar a não inserção de outras informações ou para evitar fraudes. Era muito comum o texto "blocado", sem espaços entre as linhas, parágrafos, nos quais o final das frases era preenchido com tracejado (----) ou traço ponto (-..-.-..).

Esse recurso era utilizado principalmente após os dois pontos, como por exemplo:

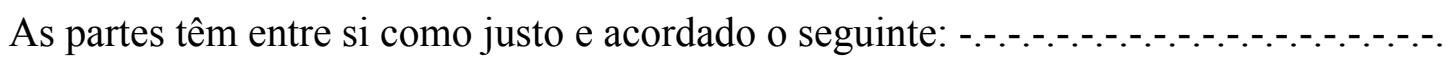

No início do uso do computador, houve uma diminuição no preenchimento das linhas, o que tornou a apresentação da tradução mais clara:

As partes têm entre si como justo e acordado o seguinte: -.

Antigamente, era muito comum a expressão "texto corrido", uma vez que os recursos das máquinas datilográficas eram limitados ou exigiam uma grande habilidade do tradutor em criar tabelas, o que aumentava consideravelmente o tempo de realização do trabalho. Atualmente, os recursos de informática, softwares, conversores do formato PDF em Word 
permitem que sejam realizados textos espelhados, apresentando uma aparência quase que idêntica ao documento original. A leitura das traduções tornou-se mais clara, facilitada, principalmente quanto à identificação e o reconhecimento dos itens ou campos traduzidos por uma pessoa que desconheça o idioma estrangeiro.

Por fim, ainda neste subitem observamos o realce de palavras existentes no texto original, tais como o negrito, itálico ou sublinhado, a fim de averiguarmos se há uma tendência por parte dos tradutores em seguir ou não esse padrão na tradução.

h) Fecho com informações de emolumentos: conforme mencionado no item f) acima, segue o teor do modelo para o fecho da tradução, que permaneceu afixado na Diretoria do Serviço de Fiscalização da Secretaria de Desenvolvimento Econômico Ciência, Tecnologia e Inovação da Junta Comercial do Estado de São Paulo :

Nada mais constava do documento acima que devolvo com esta tradução, segundo o meu melhor entendimento.

Lavrada em ___ laudas, a qual conferi, achei conforme e assino.

Emolumentos R\$

Talão $\mathrm{n}^{\mathrm{o}} \ldots$, Recibo $\mathrm{n}^{\mathrm{O}}$

São Paulo,

i) Assinatura com firma reconhecida - a tradução juramentada é válida em todo o território nacional, todavia, é recomendável o reconhecimento da firma do tradutor, principalmente se a tradução for utilizada em cidade ou estado diferentes daqueles de residência do tradutor, visto que poderá ser exigido pelos órgãos públicos. Por exemplo, o Escritório de Representação em São Paulo (ERESP) do Ministério das Relações Exteriores esclarece em seu site, no tocante a traduções que "legaliza apenas traduções, livres ou juramentadas, que contenham o reconhecimento de firma, em Cartório do Estado de São Paulo, do tradutor."

j) Selo seco ou na forma de adesivo do tradutor público - no parágrafo $2^{\circ}$ do artigo 13 da deliberação fica facultado o uso de sinete ou selo de identificação, com a ressalva de que não poderão ser feitas referências a outras pessoas ou entidades nos impressos dos tradutores, conforme segue:

É vedado aos tradutores públicos e intérpretes comerciais inscreverem, nos impressos que utilizarem para o exercício de seu ofício, referências a quaisquer outras pessoas ou entidades públicas ou privadas, dísticos, siglas, insígnias, ou quaisquer outros sinais. Se desejarem, poderão apor sinete ou 
selo que os identifique pessoalmente, assim como referências ao endereço de seu ofício, C.E.P. (Código de Endereçamento Postal), telefone, fax, e-mail e o que mais for pertinente para identificação pessoal. (grifo nosso)

k) Carimbo do tradutor no verso do documento original - o parágrafo único do artigo 16 da deliberação n⿳0 04 determina que: "As certidões de tradução ou versão, na forma do disposto no artigo 18 do Decreto Federal 13.609/43, deverão acompanhar sempre os documentos originais, ou cópias autênticas a que se referirem.” Por sua vez, o referido Decreto Federal 13.609/43 que regulamenta o ofício, em seu artigo 18 estabelece que:

Art. 18. Nenhum livro, documento ou papel de qualquer natureza que fôr exarado em idioma estrangeiro produzirá efeito em repartições da União dos Estados e dos municípios, em qualquer instância, Juízo ou Tribunal ou entidades mantidas, fiscalizadas ou orientadas pelos poderes públicos, sem ser acompanhado da respectiva tradução feita na conformidade dêste regulamento.

Sendo assim, é de praxe que o tradutor carimbe e/ou rubrique e anote o número da tradução no verso do documento original.

\section{Tradução intersemiótica:}

Ocorre quando itens como figuras, logos, selos e outros são traduzidos textualmente (Aubert, 1998:138).

No documento escolar que originou nosso corpus de pesquisa, observamos os seguintes itens possíveis de serem traduzidos na modalidade de tradução intersemiótica:
A- Brasão do Estado de São Paulo
B- Carimbo da Escola
C- Autenticação da cópia
D- Carimbo de emendas
E- Assinaturas do Secretário e Diretor no documento

Notas do tradutor - são observações extra-tradutórias (ou seja, informações que não constam no texto original, porém, que em grande parte das vezes se fazem necessárias) realizadas para fins de esclarecimento de algum termo, sistema jurídico, educacional, ou como justificativa pela omissão de itens em branco e/ou não aplicáveis. Observamos o modo pelo qual essas 
notas, que representam “a voz do tradutor” (Zavaglia, 2014:39-48), são inseridas, seja por meio de colchetes ou parênteses, bem como sua frequência.

\section{Perfil - destaque de tendências do tradutor após a aplicação do modelo das modalidades de tradução}

Com base no gráfico representado no início de cada ficha descritiva, elaborado a partir dos dados obtidos com a aplicação do modelo das modalidades de tradução em nosso corpus de pesquisa, destacamos as tendências apresentadas pelos tradutores, com exemplos e comparações dos dados estatísticos.

Tendo em vista a complexidade para se definir a classificação exata do perfil do tradutor, apresentamos, a título de sugestão, possíveis descrições das estratégias e posturas adotadas pelos tradutores. Dentre as denominações que optamos por descrever os perfis, estão o perfil conservador, o detalhista, o objetivo ou o moderado (híbrido), que serão detalhados no decorrer deste capítulo. 
Ficha descritiva do perfil dos doze tradutores

\subsubsection{Ficha descritiva do perfil do Tradutor 1 - Grupo de 1978}

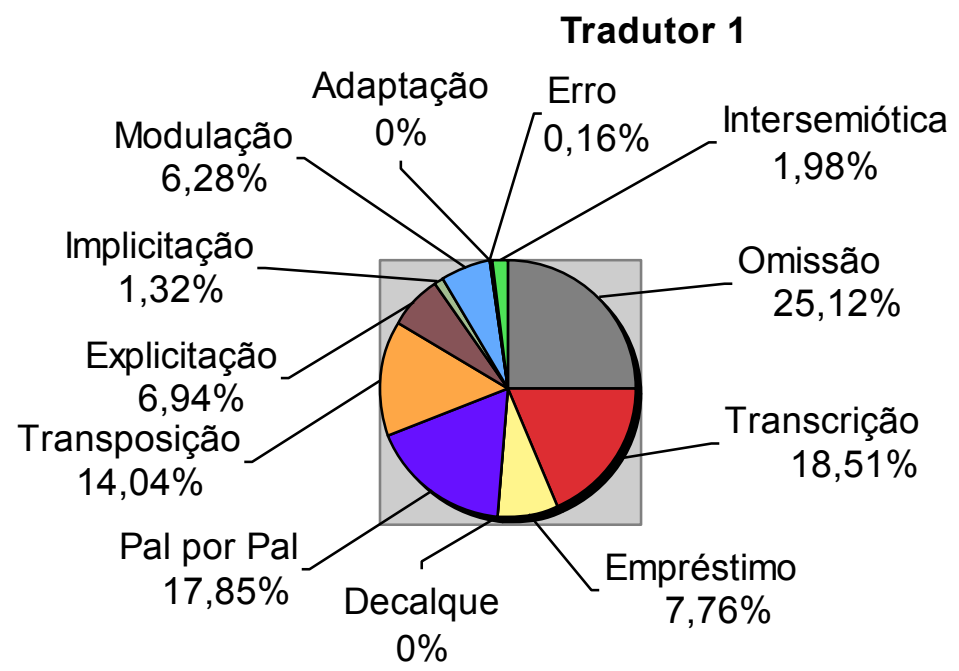

$$
\begin{aligned}
& \square \text { Omissão } \\
& \square \text { Transcrição } \\
& \square \text { Empréstimo } \\
& \square \text { Decalque } \\
& \square \text { Pal por Pal } \\
& \square \text { Transposição } \\
& \square \text { Explicitação } \\
& \square \text { Implicitação } \\
& \square \text { Modulação } \\
& \square \text { Adaptação } \\
& \square \text { Erro } \\
& \square \text { Intersemiótica }
\end{aligned}
$$

\section{Apresentação da tradução - Aparência geral do documento impresso}

a) Papel timbrado do tradutor contém as informações completas exigidas pela deliberação do ofício: $\operatorname{sim}$

b) Uso do Brasão da República Federativa do Brasil: sim, à margem esquerda do cabeçalho

c) Cor do papel e impressão: papel branco e impressão a laser tinta preta; tradução com total de três páginas grampeadas

d) Uso de marca d'água: não

e) Número de tradução, livro e folhas: sim, traduzidos:

Official Translation No. - Register - pages

f) Introito: detalhado com o título do documento original

I, [NAME], a certified public translator for Portuguese, English and French in São Paulo, Brazil, do hereby certify that this is a true and complete translation of a document in the PORTUGUESE language, entitled "Histórico Escolar - $2^{\circ}$ GRAU" 
g) Corpo do texto: texto no formato retrato, não utilizou letra Times New Roman 12, alinhamento justificado e sem o uso do tracejado ao final dos parágrafos. Houve pouca variação no tamanho da letra, proporcionando boa leitura do texto. A tabela com as disciplinas e notas está simplificada, clara e de fácil leitura. Não reproduziu todos os realces e negritos do original, destacando apenas o nome da estudante e o título do documento.

h) Fecho: os emolumentos foram mencionados na parte da assinatura

NOTHING FURTHER. IN TESTIMONY WHEREOF I hereunto set my hand and seal, at São Paulo, State of São Paulo, Brazil, this $23^{\text {rd }}$ day of July, 2013.

i) Assinatura com firma reconhecida: consta assinatura, porém sem reconhecimento de firma. Abaixo da assinatura, consta:

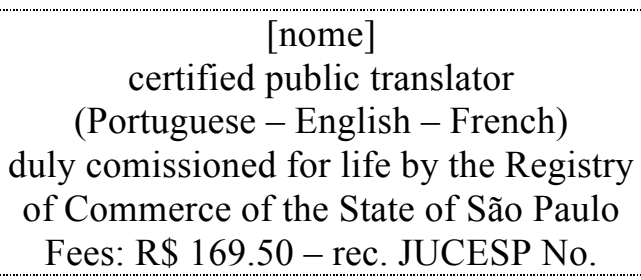

j) Selo seco ou na forma de adesivo do tradutor público: constam tanto o selo seco no início da tradução, quanto um selo adesivo afixado ao lado da assinatura do tradutor.

k) Carimbo do tradutor no verso do documento original: sim, com a informação do número da tradução apenas

\section{Tradução intersemiótica}

O tradutor 1 optou por mencionar os brasões, autenticações e assinaturas, com a omissão de um item, conforme segue:

A- Brasão do Estado de São Paulo: [coat of arms]

B- Carimbo da Escola: omitiu

C- Autenticação da cópia: [Original document submitted for translation jointly with a copy certified on both pages as a true copy of the original by the Second General Registry of São 
Paulo (district of Liberdade), duly signed and dated 04 October 2012, with authenticity seals of the Notary Association of Brazil - São Paulo chambre]

D- Carimbo de emendas: não mencionou a palavra carimbo. Traduziu o conteúdo: This document contains no erasures or amendments. Prepared by [initials]

E- Assinaturas do Secretário e Diretor no documento: não mencionou a legibilidade da assinatura

[signature] Registrar - Norimar Romano Arenghi - id. RG 6688015

\section{Notas do tradutor}

As notas explicativas foram apresentadas entre colchetes. Na menção da autenticidade da cópia, demonstrou forte tendência explicativa na inserção de informações extra-tradutórias.

\section{Perfil - destaque de tendências do tradutor após a aplicação do modelo das modalidades de tradução.}

O tradutor 1 apresentou forte tendência à explicitação com um percentual de 6,94\%, o maior em seu grupo, e o segundo maior, ao compararmos as duas gerações. Para exemplificar, podemos destacar, logo no início da tradução, a inserção antes do nome da Escola de [Name of public school]; a complementação, entre colchetes, da tradução de $2^{\circ}$ Grau por Secondary School [Senior High School] e third year seguido da explicação [last], com o intuito de reforçar o fato de o terceiro ser o último ano do Ensino Médio no Brasil. O percentual de 6,68\% na modulação pode demonstrar uma tendência, em algumas partes, ao afastamento da língua de partida, como no caso da tradução de Parte Diversificada por Diversified Syllabus e Educação Moral e Cívica por Civics, em vez de Diversified Part e Moral and Civic Education, respectivamente, como optou a maioria dos tradutores. Não apresentou erros na transcrição de notas e carga horária. Considerando-se a apresentação geral e estratégias escolhidas na tradução, o tradutor 1 apresentou tendência a ter um perfil detalhista e conservador. 


\subsubsection{Ficha descritiva do perfil do Tradutor 2 - Grupo de 1978}

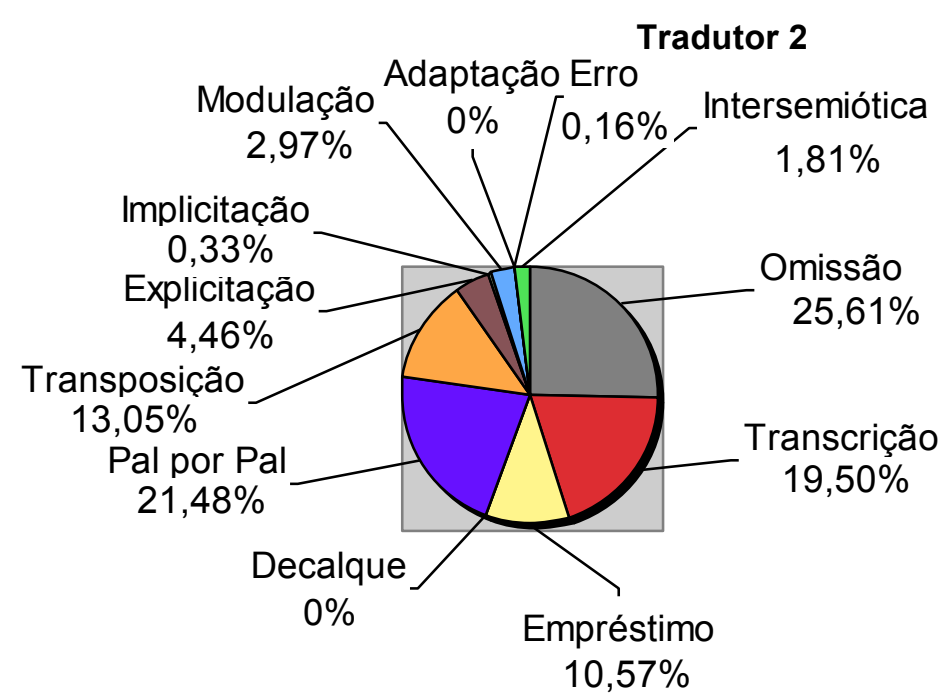

口 Omissão

$\square$ Transcrição

口Empréstimo

口Decalque

$\checkmark$ Pal por Pal

¿Transposição

๑Explicitação

口 Implicitação

口 Modulação

口 Adaptação

$\square$ Erro

口 Intersemiótica

\section{Apresentação da tradução - Aparência geral do documento impresso}

a) Papel timbrado do tradutor contém as informações completas exigidas pela deliberação do ofício: sim, porém, o tradutor seguiu as orientações contidas no site da junta comercial na época da posse do grupo de 1998. O cabeçalho possui informação adicional do número do INSS não solicitada na deliberação, tampouco no site.

b) Uso do Brasão da República Federativa do Brasil: sim, à margem esquerda do cabeçalho

c) Cor do papel e impressão: papel branco e impressão a laser tinta preta; tradução com total de quatro páginas soltas

d) Uso de marca d'água: não

e) Número de tradução, livro e folhas: sim, em vernáculo:

Tradução/Versão No. - Livro No. - Fls.

f) Introito: detalhado com o título do documento original

I, the undersigned, Public and Sworn Translator, do hereby certify that on this date there was brought before me a document, in the Portuguese Language, describing - SCHOOL RECORDS - which I here translate into English as follows: 
g) Corpo do texto: texto no formato retrato, não utilizou letra Times New Roman 12, alinhamento justificado e sem o uso do tracejado ao final dos parágrafos. Houve diminuição no tamanho da letra apenas na tabela com as disciplinas e notas, que está simplificada, clara e de fácil leitura. Reproduziu todos os realces e negritos do original.

h) Fecho: os emolumentos foram mencionados na parte da assinatura; inadequação nos tempos verbais de acknowledge and sign que no present perfect correspondem a have acknowledged and signed.

There was nothing further in the above document, which I am returning together with this translation, which I have checked, acknowledge and sign and to which I attest. [copiar data]

i) Assinatura com firma reconhecida: consta assinatura, porém sem reconhecimento de firma. Ao lado da assinatura, consta em vernáculo:

Recibo: [número]

Emolumentos: 4984 carac.

escola maria trujilo torloni

j) Selo seco ou na forma de adesivo do tradutor público: constam um selo seco ao lado da assinatura do tradutor, um selo adesivo afixado ao final da tradução e, em cada página, à margem superior direita, o carimbo do tradutor rubricado.

k) Carimbo do tradutor no verso do documento original: sim, com a informação do número da tradução, livro e páginas

\section{Tradução intersemiótica}

O tradutor 2 optou por descrever os brasões e traduzir na íntegra as autenticações, conforme segue:

A- Brasão do Estado de São Paulo: (on the upper left-hand corner the coat of arms of the State of São Paulo and the rubber stamp of the school) 
B- Carimbo da Escola: conforme item A acima (... and the rubber stamp of the school)

C- Autenticação da cópia: o teor da autenticação foi traduzido na íntegra:

Rubber stamp on face and reverse as follows:

Registrar of the Civil Registry of Natural Persons of the 2nd Subdistrict - Liberdade - SP Capital City

\section{CERTIFIED COPY}

I certify that this copy is in accordance with the original presented to me, to which I attest.

São Paulo, October 4, 2012.

(sgd) Veronica Silva Araujo do Rosário

Authorized Clerk

Each certified copy: $\mathrm{R} \$ 2,35$

Valid only with the authenticity stamp

D- Carimbo de emendas: não mencionou a palavra carimbo. Traduziu o conteúdo:

This document contains neither erasures nor amendments.

Prepared by: (initial)

Checked by: (blank)

E- Assinaturas do Secretário e Diretor no documento: não mencionou a legibilidade da assinatura

(sgd) Norimar Romano Arenghi

School Registrar - Personal I.D. Card (RG) 6.688.015

\section{Notas do tradutor}

As notas explicativas foram apresentadas entre parênteses. Inseriu uma nota do tradutor referente ao sistema educacional do Brasil:

Translator's note. According to the Brazilian Education System, Secondary School consists of 3 (three) years.

Perfil - destaque de tendências do tradutor após aplicação do modelo das modalidades de tradução. 
O percentual de 4,46\% de explicitação evidencia a tendência do tradutor 2 em se ater mais aos detalhes, principalmente no tocante a siglas como SE, que corresponde a Secretaria de Educação, traduzida por State Department of Education (SE) e a sigla CEE de Conselho Estadual de Educação, traduzida por State Board of Education (CEE). Essa tendência ficou mais evidente, inclusive, nas traduções intersemióticas, por exemplo, ao identificar a posição exata do brasão do Estado de São Paulo em (on the upper left-hand corner the coat of arms of the State of São Paulo). O carimbo de autenticação da cópia, em geral, mencionado pelos demais tradutores, foi traduzido na íntegra pelo tradutor 2. Apresentou um percentual menor de modulação com 2,97\% e maior percentual de palavra por palavra com 21,48\%. Não houve erros na transcrição das notas e carga horária. Considerando-se a apresentação geral e estratégias escolhidas na tradução, o tradutor 2 apresentou tendência a ter um perfil detalhista e conservador. 


\subsubsection{Ficha descritiva do perfil do Tradutor 3 - Grupo de 1978}

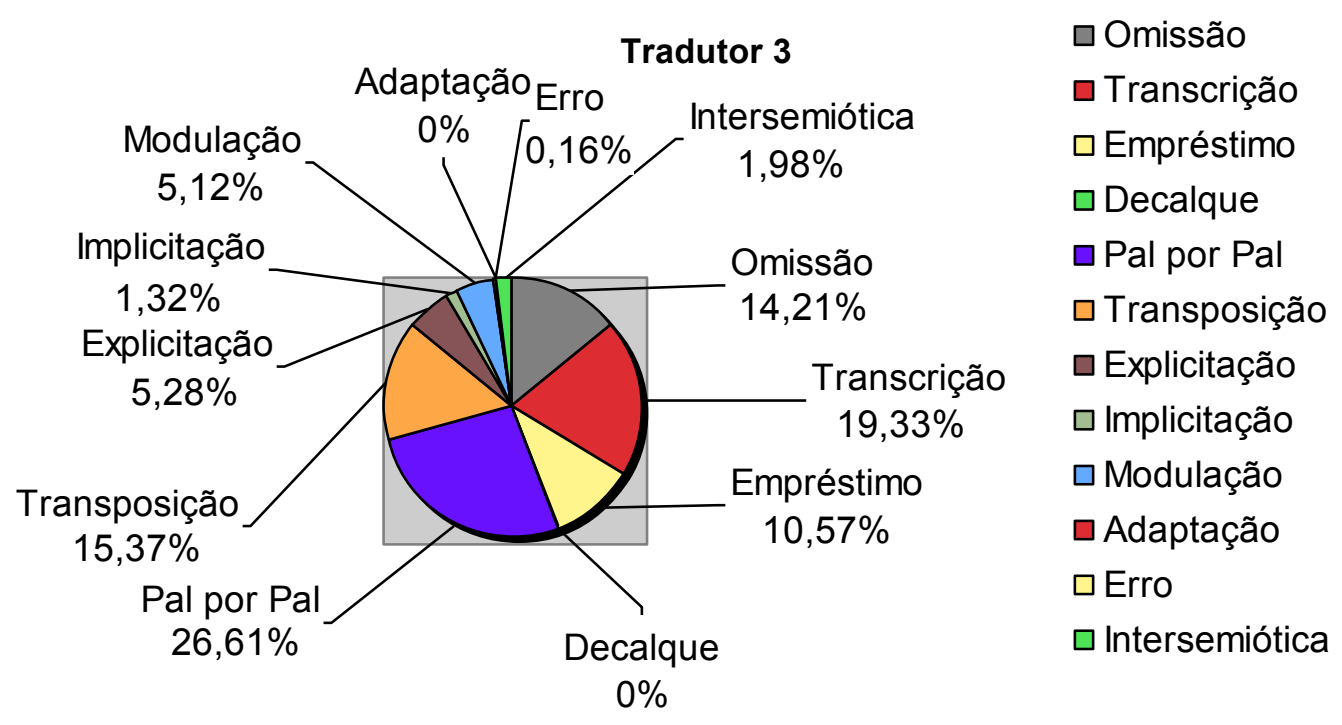

\section{Apresentação da tradução - Aparência geral do documento impresso}

a) Papel timbrado do tradutor contém as informações completas exigidas pela deliberação do ofício: não, faltaram informações sobre o endereço

b) Uso do Brasão da República Federativa do Brasil: sim, na parte central do cabeçalho

c) Cor do papel e impressão: papel branco e impressão matricial com tinta preta; tradução com total de quatro páginas grampeadas

d) Uso de marca d'água: não

e) Número de tradução, livro e folhas: sim, em vernáculo:

$$
\mathrm{N}^{\mathrm{o}} \text { da tradução/versão: }- \text { livro }^{\circ}-\text { fls. }
$$

f) Introito: detalhado com o título do documento original

I, the undersigned, in my capacity as sworn translator in São Paulo, State of São Paulo, have duly translated into English the following document written in Portuguese (Histórico Escolar - $2^{\circ}$ Grau, EE “Maria Trujilo Torloni"-Vivian X. Orosco, 22-IV-99), which bears my seal and signature.-

g) Corpo do texto: texto no formato retrato, não utilizou letra Times New Roman 12, alinhamento justificado e com o uso do tracejado ao final dos parágrafos. O texto da tradução 
ocupa toda a folha e não há espaço entre as linhas ou parágrafos, o que pode causar cansaço na leitura do texto. Não houve variação no tamanho da letra. A tabela com as disciplinas e notas está um pouco confusa, fato que pode vir a dificultar a leitura. Não reproduziu todos os realces e negritos do original, com destaques apenas no início do documento, principalmente para o nome da estudante e o título do documento.

h) Fecho: extremamente detalhado, inclusive com menção da deliberação dos emolumentos e do número de linhas da tradução:

WITNESS MY HAND AND SEAL in São Paulo, SP, Federative Republic of Brazil this fifth day of July, 2013 A.D. Emls. (fee) R\$210.18 (Del. JUCESP No. 05/11 - D.O. 29-XI-11)

B-V-93 lines - R.N. [número]

The Translator

i) Assinatura com firma reconhecida: consta assinatura, porém sem reconhecimento de firma. Abaixo da assinatura, consta um carimbo do tradutor:

\begin{tabular}{|c|}
\hline [nome] \\
Tradutor Público e Intérprete Comercial \\
[Endereço] \\
phone: [manuscrito] \\
[email]
\end{tabular}

j) Selo seco ou na forma de adesivo do tradutor público: constam um selo seco ao lado da assinatura do tradutor e, em cada página, à margem inferior esquerda, o carimbo do tradutor rubricado.

k) Carimbo do tradutor no verso do documento original: sim, com a informação do número da tradução, livro e páginas.

\section{Tradução intersemiótica}

O tradutor 3 optou por descrever os brasões, autenticações e assinaturas, conforme segue:

A- Brasão do Estado de São Paulo: [Great Seal of the State of São Paulo]

B- Carimbo da Escola: descreveu de forma detalhada todas as informações: 
[Stamped: E.E. MARIA TRUJILO TORLONI - Estrada das Lágrimas, 579 - São José District - CEP 09581-300 - Phone: 4238-7686 / S.C. Sul - Administrative Unit: 41,186 - SD 02,231].-

C- Autenticação da cópia:

[On the face and reverse of the document translated above is the original stamp of notarization (authentication of the relevant copy) by the $3^{\text {rd }}\left(2^{\text {nd }}\right)$ Civil Register Officer, $3^{\text {rd }}\left(2^{\text {nd }}\right)$ Subdistrict of Liberdade, Capital City, initialled and dated October 04, 2012, accompanied by an adhesive holographic Authenticity Seal.].-

D- Carimbo de emendas: não mencionou a palavra carimbo. Traduziu o conteúdo:

This document contains no amendments or erasures. Done by: [initials] - Checked by: [nihil]

E- Assinaturas do Secretário e Diretor no documento: não mencionou a legibilidade da assinatura:

[signed:] [i] Norimar Romano Arenghi, R.G. 6,688,015, School's Secretary

\section{Notas do tradutor}

As notas explicativas foram apresentadas entre colchetes. Além da menção da autenticidade da cópia, demonstrou novamente uma tendência mais explicativa na inserção de informações extra-tradutórias por meio das seguintes notas ao final da tradução:

[Translator's Notes: -1 . The $1^{\text {st }}, 2^{\text {nd }}$, and $3^{\text {rd }}$ Grades in Brazilian higher secondary programs (segundo grau) are US complete Senior High School equivalente. - 2. Other data and blanks are not applicable and / or filled in, and, accordingly, have not been translated. - 3. In the lower left-hand corner of the face and reverse: Wilson's Computer - 7610 - 3104].-

O tradutor 3 não aderiu à instrução da cliente sobre o país de destino (Canadá), conforme observamos na nota número 1 em que menciona US, ou seja, dos Estados Unidos.

\section{Perfil - destaque de tendências do tradutor após aplicação do modelo das modalidades de tradução.}

O tradutor 3 apresentou forte tendência à explicitação com um percentual de 5,28\%, o segundo maior em seu grupo, com características repetitivas, por exemplo em relação às 
siglas. A sigla SP do Estado de São Paulo foi traduzida com explicitação, seja na forma [State of São Paulo] ou [São Paulo] ou com a inserção de [State of] antes de São Paulo. As resoluções e deliberações pertinentes ao funcionamento da escola e ao currículo escolar também foram explicitadas, mediante complementos do tradutor ao inserir, por exemplo, [published in the] DOE [State Official Gazette] na parte referente à publicação no diário oficial, em que no original consta apenas DOE 10/12/84. Devemos destacar o elevado percentual de palavra por palavra de $26,61 \%$, que reforça a tendência à proximidade ao original. Não houve erros na transcrição das notas e carga horária. Considerando-se a apresentação geral e estratégias escolhidas na tradução, principalmente pela grande quantidade de notas do tradutor e inserções explicativas, o tradutor 3 tende a ter um perfil detalhista e extremamente conservador, inclusive no formato de apresentação da tradução em texto corrido. A título de curiosidade e um fato inusitado, o tradutor 3 fez questão de ler, por telefone, todo o conteúdo da tradução para a cliente antes da entrega do documento. 


\subsubsection{Ficha descritiva do perfil do Tradutor 4-Grupo de 1978}

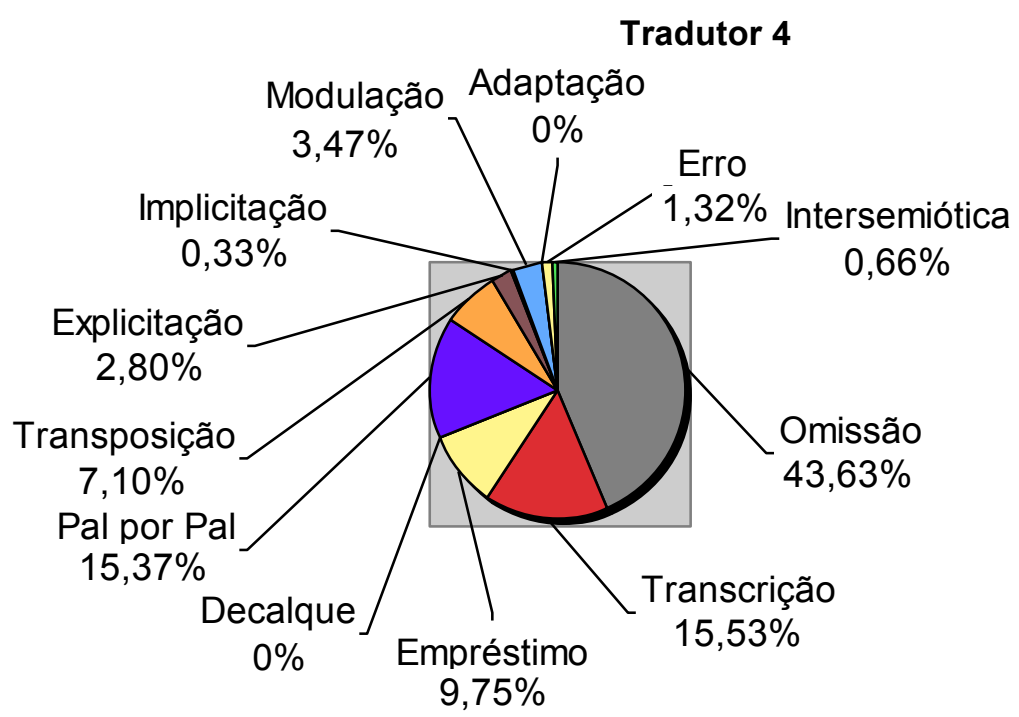

๑ Omissão

$\square$ Transcrição

口Empréstimo

口Decalque

$\square$ Pal por Pal

口Transposição

- Explicitação

口 Implicitação

口 Modulação

口 Adaptação

$\square$ Erro

$\square$ Intersemiótica

\section{Apresentação da tradução - Aparência geral do documento impresso}

a) Papel timbrado do tradutor contém as informações completas exigidas pela deliberação do ofício: $\operatorname{sim}$

b) Uso do Brasão da República Federativa do Brasil: não

c) Cor do papel e impressão: papel branco e impressão a jato de tinta preta; tradução com total de duas páginas grampeadas

d) Uso de marca d'água: não

e) Número de tradução, livro e folhas: sim, em vernáculo:

$$
\text { Tradução } \mathrm{N}^{\mathrm{o}}-\mathrm{L} \text { - FLS }
$$

f) Introito: detalhado com a descrição do tipo de documento original

I, a Public Sworn Translator accredited by the Board of Commerce of the State of São Paulo, Federative Republic of Brazil, hereby certify and attest, for lawful purposes, that on this date, a document drawn up in Portuguese - the original of a full curriculum - was presented to me for translation into English, and that I have made said translation as follows:

g) Corpo do texto: texto no formato retrato, utilizou letra Times New Roman, porém em tamanho menor que 12, alinhamento justificado e sem o uso do tracejado ao final dos 
parágrafos. Houve pouca variação no tamanho da letra, proporcionando boa leitura do texto. A tabela com as disciplinas e notas está clara e de fácil leitura, porém bem simplificada. Não reproduziu todos os realces e negritos do original, destacando apenas o nome da escola, da estudante e o título do documento.

h) Fecho: os emolumentos foram mencionados na parte da assinatura

NOTHING ELSE appeared in the above document, which translation I have prepared, revised, found correct and signed. São Paulo, June $29^{\text {th }}, 2013$.

i) Assinatura com firma reconhecida: consta assinatura, porém sem reconhecimento de firma. Abaixo da assinatura, consta em vernáculo:

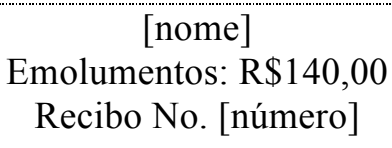

j) Selo seco ou na forma de adesivo do tradutor público: não constam selos do tradutor

k) Carimbo do tradutor no verso do documento original: sim, com as informações do número da tradução, livro e páginas.

\section{Tradução intersemiótica}

O tradutor 4 optou por descrever o brasão e mencionar alguns carimbos, porém, omitiu a autenticação, conforme segue:

A- Brasão do Estado de São Paulo: (Coat of Arms of the State of São Paulo)

B- Carimbo da Escola: (School Stamp)

C- Autenticação da cópia: omitiu

D- Carimbo de emendas: omitiu

E- Assinaturas do Secretário e Diretor no documento: mencionou a legibilidade da assinatura: (sgd) illegible

Norimar Romano Arenghi

School Secretary 
RG 6.688.015

\section{Notas do tradutor}

As poucas notas explicativas foram apresentadas entre parênteses. Não inseriu nota do tradutor para justificar a omissão ou não relevância do trecho de transferência durante o ano letivo.

\section{Perfil - destaque de tendências do tradutor após aplicação do modelo das modalidades de tradução.}

O tradutor 4 apresentou o percentual mais elevado de omissões entre os dois grupos, com $43,63 \%$. A média de omissões nos grupos ficou entre $20,79 \%$ e $22,20 \%$, devido ao trecho não preenchido no documento original referente à transferência durante o período letivo. Todavia, além do referido trecho omitido pela maioria, o tradutor 4 não traduziu partes do documento original, como a legenda das notas e conceitos (A - Excelente, B - Bom, etc.) tampouco, informações como a autenticação da cópia e o carimbo de ausência de emendas e rasuras. Apresentou pouca tendência explicativa com o percentual de 2,80\%. Houve erros na transcrição das notas e carga horária, e o percentual de erro de $1,32 \%$ foi o maior no grupo de 1978. Considerando-se a apresentação geral e estratégias escolhidas na tradução, o tradutor 4 apresentou tendência a ter um perfil extremamente objetivo e pouco conservador, principalmente pela ausência de características oficiais na tradução apresentada, podendo haver comprometimento da segurança jurídica do documento. 


\subsubsection{Ficha descritiva do perfil do Tradutor 5 - Grupo de 1978}

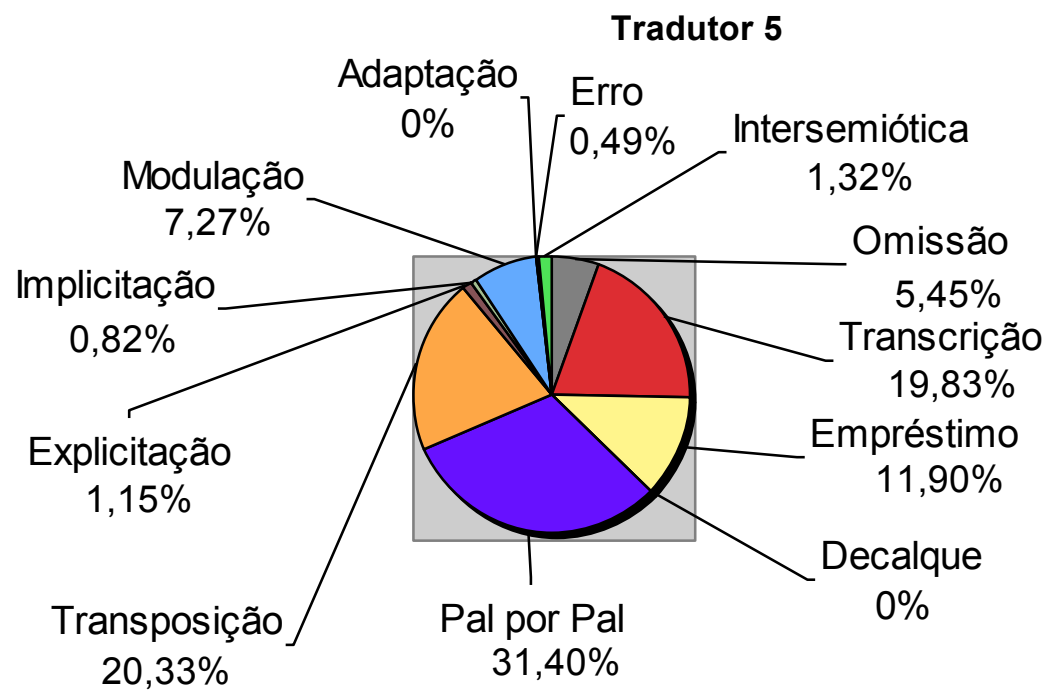

\section{Apresentação da tradução - Aparência geral do documento impresso}

a) Papel timbrado do tradutor contém as informações completas exigidas pela deliberação do ofício: sim

b) Uso do Brasão da República Federativa do Brasil: não

c) Cor do papel e impressão: papel branco e impressão a laser tinta preta; tradução com total de três páginas soltas

d) Uso de marca d'água: não

e) Número de tradução, livro e folhas: sim, em vernáculo:

$$
\text { Tradução No. - L. - FLS. }
$$

f) Introito: detalhado com a descrição do tipo do documento original

I, the undersigned, a Sworn Translator authorized by the laws of the Federative Republic of Brazil and, especially, by the Board of Commerce of the State of São Paulo, Brazil, to act within the said State, do hereby certify that on the date hereof an authenticated copy of a Transcript was presented to me for translation from Portuguese into English, and that I have made such translation as follows: 
g) Corpo do texto: texto no formato retrato, utilizou letra Times New Roman, porém em tamanho menor que 12, alinhamento justificado e sem o uso do tracejado ao final dos parágrafos. Houve variação no tamanho da letra, entretanto, não prejudicou a leitura do texto. A tabela com as disciplinas e notas está quase que idêntica ao documento original e de fácil leitura. O tradutor reproduziu todos os realces e negritos do original.

h) Fecho: extremo detalhamento, com menção inclusive do número de páginas e que a impressão foi feita apenas no anverso; os emolumentos foram mencionados após a assinatura

NOTHING ELSE APPEARED IN THE AFORESAID DOCUMENT, which is returned to the party interested together with this translation (consisting of three printed pages, each printed on one side only) checked for accuracy, found correct and signed by me. São Paulo, July 01, 2013.

i) Assinatura com firma reconhecida: consta assinatura, porém sem reconhecimento de firma. Abaixo da assinatura, consta:

[nome]

Fees: R\$246.68

Receipt no. [número] - Receipt Book No. [número]

j) Selo seco ou na forma de adesivo do tradutor público: não constam selos do tradutor

k) Carimbo do tradutor no verso do documento original: sim, sem informar os números da tradução, livro ou páginas

\section{Tradução intersemiótica}

O tradutor 5 optou por descrever os brasões, autenticações e assinaturas, conforme segue:

A- Brasão do Estado de São Paulo: o tradutor incluiu aspas no início e final da tradução: "Letterhead (Official State seal)

B- Carimbo da Escola: (Stamp of the State School "Maria Trujilo Torloni" at the top of the front page of the document.) 
C- Autenticação da cópia: (Rubber stamp of the Civil Registrar of Natural Persons for the $2^{\text {nd }}$ Subdist. - Liberdade, São Paulo, SP, dated 10/04/2012, on both pages of the document, attesting it to be a true copy of the original. Related initialed adhesive authenticity labels no. 1074AB459462 and 1074AB459461 of the Brazilian College of Notaries, SP.)"----

D- Carimbo de emendas: não mencionou a palavra carimbo. Traduziu o conteúdo:

This document does not contain amendments or erasures.

Prepared by: (illegible signature)

Checked by: (left blank)

E- Assinaturas do Secretário e Diretor no documento: mencionou a legibilidade da assinatura (illegible signature)

Norimar Romano Arenghi

R.G. 6.688 .015

School Secretary

\section{Notas do tradutor}

As notas explicativas foram apresentadas entre parênteses. Na maior parte das menções, demonstrou pouca tendência explicativa na inserção de informações extra-tradutórias.

\section{Perfil - destaque de tendências do tradutor após aplicação do modelo das modalidades de tradução.}

O tradutor 5 apresentou o percentual de omissão de 5,45\%, o menor em seu grupo e o segundo menor entre todos os tradutores observados. Esse valor deve-se ao fato de que o tradutor 5 incluiu na tradução a parte referente à transferência durante o período letivo, que não foi traduzida pela maioria dos tradutores por estar em branco no documento original. Esse fato acarretou um aumento no percentual de tradução palavra por palavra $(31,40 \%)$, devido à repetição do quadro das disciplinas. Entretanto, não significa uma tendência mais próxima do original, tendo em vista o elevado percentual de modulação com 7,27\%, o maior do grupo. Podemos destacar como exemplos de modulação, a tradução de Parte Comum por Common Requirements em vez de Common Part, conforme optou a maioria, e Parte Diversificada por Diversified Curriculum. Quanto à explicitação, com o baixo percentual de 1,15\%, o tradutor 5 
novamente demonstra objetividade ao manter as siglas conforme o original, sem explicar. Não houve erros na transcrição das notas e carga horária. Considerando-se a apresentação geral da tradução de forma clara, quase que um espelho do original, bem como as estratégias escolhidas na tradução, o tradutor 5 tende a ter um perfil mais objetivo, mesmo tendo optado por omitir o mínimo possível de informações. 


\subsubsection{Ficha descritiva do perfil do Tradutor 6 - Grupo de 1978}

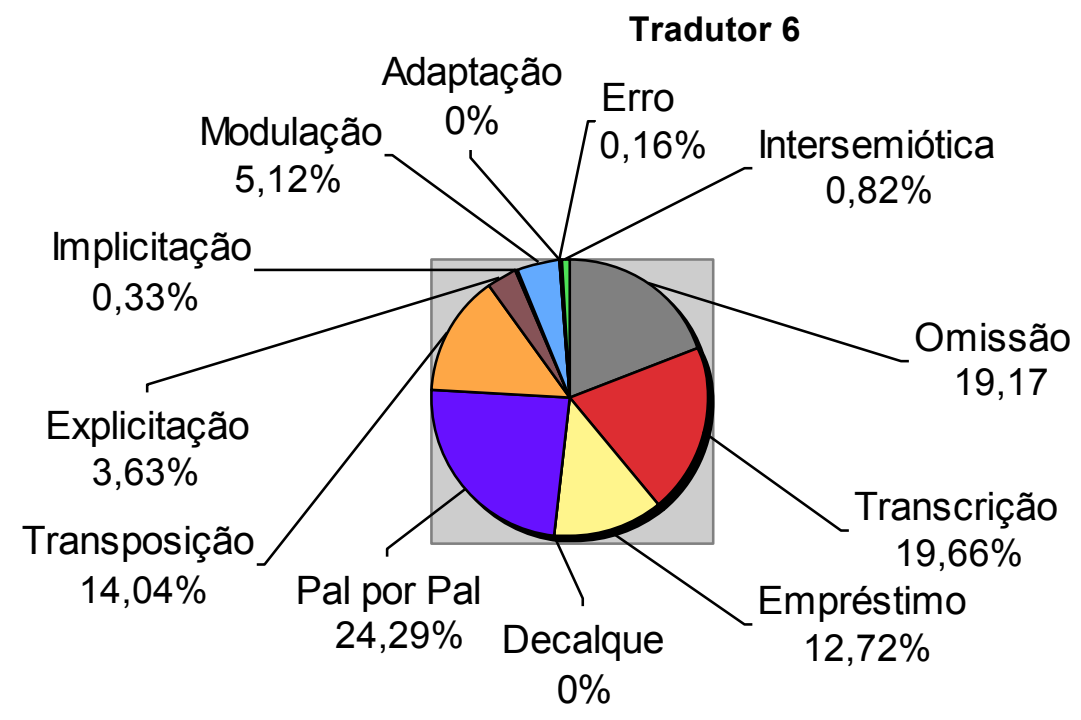

\section{Apresentação da tradução - Aparência geral do documento impresso}

a) Papel timbrado do tradutor contém as informações completas exigidas pela deliberação do ofício: sim. Contém outros dois números ISS e IAPAS não solicitados na deliberação.

b) Uso do Brasão da República Federativa do Brasil: sim, colorido, na parte central do cabeçalho

c) Cor do papel e impressão: papel branco e impressão a laser tinta preta; cabeçalho na cor verde; tradução com total de três páginas grampeadas

d) Uso de marca d'água: sim, com o brasão da República Federativa do Brasil na cor verde

e) Número de tradução, livro e folhas: sim, em vernáculo:

$$
\text { LIVRO N }{ }^{\circ}-\text { FOLHA N }{ }^{\circ}-\text { TRADUÇÃO } N^{\circ}
$$

f) Introito: detalhado com a descrição do tipo de documento original

I, the undersigned Sworn Public Translator and Commercial Interpreter, hereby certify this is the faithful translation of an Academic Record Transcript - High School Education written in Portuguese, which I translate as follows: 
g) Corpo do texto: texto no formato retrato, utilizou letra Times New Roman 12, alinhamento justificado e sem o uso do tracejado ao final dos parágrafos. Houve pouca variação no tamanho da letra, proporcionando boa leitura do texto. A tabela com as disciplinas e notas está clara, bem semelhante ao original. O tradutor reproduziu todos os realces e negritos do original. Todavia, há pouco espaço entre os parágrafos, tornando a leitura cansativa de modo geral.

h) Fecho: os emolumentos não foram mencionados

Nothing else was contained in said original, which I return with this faithful translation. In witness whereof, I have hereunto set my hand and seal of office, in São Paulo, this June 19, 2013.

i) Assinatura com firma reconhecida: consta assinatura, porém sem reconhecimento de firma. Abaixo da assinatura, consta:

[nome]

Sworn Public Translator

j) Selo seco ou na forma de adesivo do tradutor público: constam tanto o selo seco nas duas primeiras páginas da tradução, à margem direita, com rubricas do tradutor, quanto um selo adesivo afixado ao lado da assinatura do tradutor com fitilho verde e amarelo.

k) Carimbo do tradutor no verso do documento original: sim, com a informação do número da tradução apenas

\section{Tradução intersemiótica}

O tradutor 6 optou por mencionar os brasões, autenticações e assinaturas, conforme segue:

A- Brasão do Estado de São Paulo: [Coat of Arms of the State of São Paulo]

B- Carimbo da Escola: descrição genérica [Official Stamp] 
C- Autenticação da cópia: [There are Stamps of authentication of reprographic copy on the original document face and overleaf duly dated on October 22, 2012 and signed in the City of São Paulo and bearing seals of authentication under $n^{\circ}$ 1099AC580017 and 1099AC580016.]

D- Carimbo de emendas: não mencionou a palavra carimbo. Traduziu o conteúdo:

This document has neither amendments nor erasures.

Prepared by: [illegible signature]

Checked by: [no information on the record]

E- Assinaturas do Secretário e Diretor no documento: mencionou a legibilidade da assinatura [illegible signature]

Norimar Romano Arenghi

Id Card RG: 6.688.015

School Secretary

\section{Notas do tradutor}

As notas explicativas foram apresentadas entre colchetes. O tradutor utilizou notas para justificar a omissão do trecho referente à transferência escolar e demais campos em branco no documento original, conforme segue:

1- [N.T.: No information is provided on the record, about transfer in the respective school year];

2 - [N.T: No information on record on Certificate of Birth, Pages, Book, City and State.];

$3-$ - [N.T: No information on the record in the box 90, 91, 92, 93 of the original Academic Record Transcript regarding Resolution SE N ${ }^{\circ} 25 / 81$ - article $3 \S 4$, to be provided by the receiving school in the High School Education or Higher Education]

\section{Perfil - destaque de tendências do tradutor após aplicação do modelo das modalidades de tradução.}

O percentual de omissão $(19,17 \%)$ do tradutor 6 foi abaixo da média de seu grupo $(22,20 \%)$, todavia, demonstrou preocupação em esclarecer as referidas omissões por meio de várias notas do tradutor. No tocante à explicitação, o percentual de 3,63\% não foi o mais elevado, tampouco o menor. Na maior parte das siglas, o tradutor 6 optou por não explicar, como no 
caso de Deliberação CEE $N^{0}$ 04/95, que traduziu por CEE Resolution No. 04/95. Embora tenha demonstrado maior tendência a traduzir palavra por palavra $(24,29 \%)$, apresentou algumas modulações $(5,12 \%)$, como por exemplo, ao traduzir Parte Comum por Common Core e Parte Diversificada por Supplementary Curriculum. Não apresentou erros na transcrição de notas e carga horária. Considerando-se a apresentação geral e estratégias escolhidas na tradução, o tradutor 6 apresentou tendência a ter um perfil detalhista na utilização de várias notas do tradutor e conservador. 


\subsubsection{Ficha descritiva do perfil do Tradutor 7 - Grupo de 1998}

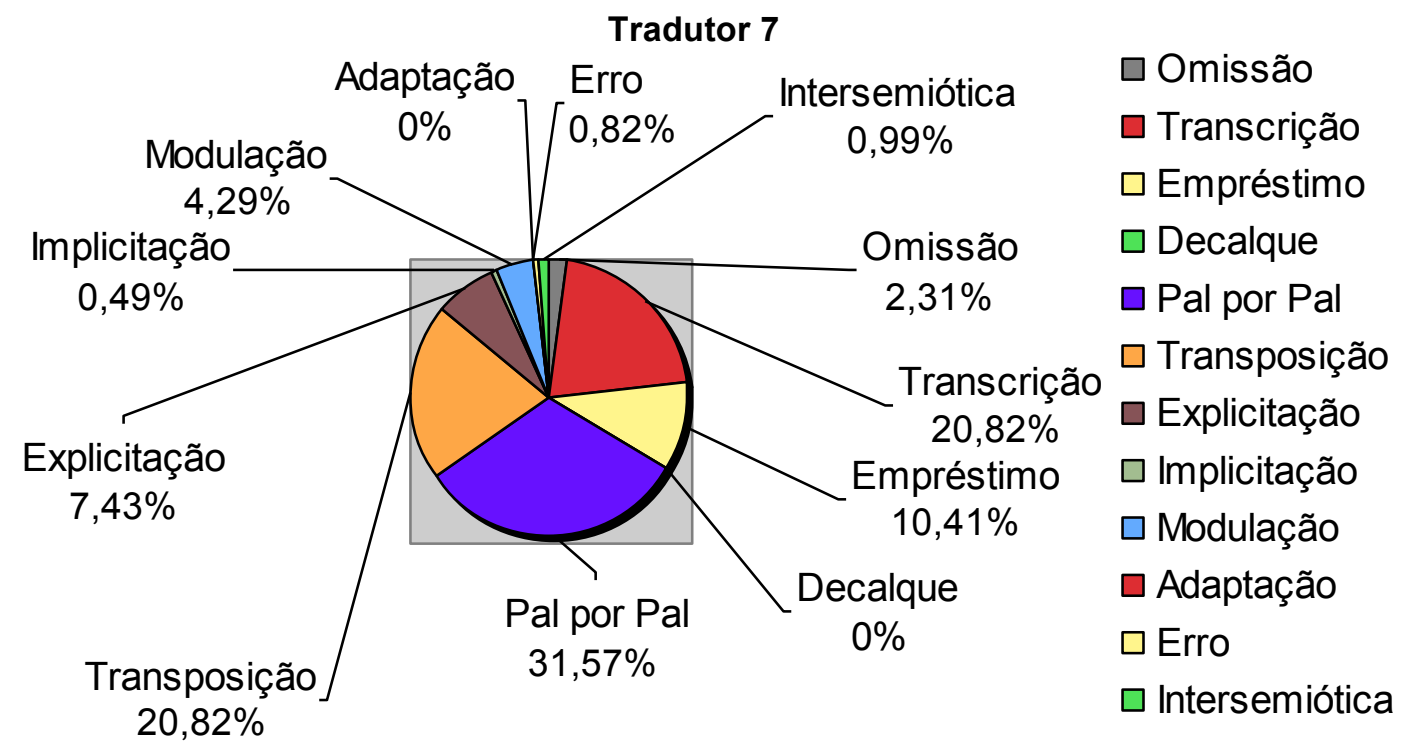

\section{Apresentação da tradução - Aparência geral do documento impresso}

a) Papel timbrado do tradutor contém as informações completas exigidas pela deliberação do ofício: não, faltou a informação sobre o número do CPF. Apesar do tradutor pertencer ao grupo mais recente, não seguiu as orientações contidas no site da junta comercial por ocasião da posse.

b) Uso do Brasão da República Federativa do Brasil: sim, colorido, à margem esquerda do cabeçalho

c) Cor do papel e impressão: papel branco e impressão a laser tinta preta; tradução com total de cinco páginas grampeadas

d) Uso de marca d'água: não

e) Número de tradução, livro e folhas: sim, traduzidos:

Translation No. - Book No. - Page

f) Introito: detalhado com o título do documento original 
I, [Name], undersigned Public Certified Translator duly admitted and sworn, do hereby certify that a document in Portuguese "Histórico Escolar" was presented to me and the true translation of which is set forth below:

g) Corpo do texto: texto no formato retrato, utilizou letra Times New Roman 12, alinhamento justificado e sem o uso do tracejado ao final dos parágrafos. Houve pouca variação no tamanho da letra, proporcionando fácil leitura do texto. A tabela com as disciplinas e notas está clara e semelhante ao documento original. Não reproduziu todos os realces e negritos do original, destacando apenas o título do documento e a palavra Certificado ao final.

h) Fecho: os emolumentos foram mencionados. Houve um erro na escrita ordinal da data, 21 th em vez de 21 st.

The above document represents all its content, which I return with this translation written within 5 (five) pages. I verified it, read it and undersign it.

Fees: $\mathrm{R} \$ 333,35$

Receipt No. [número]

São Paulo, June 21th, 2013.

i) Assinatura com firma reconhecida: consta assinatura, porém sem reconhecimento de firma. Abaixo da assinatura, consta:

[nome]

Public Sworn Translator - JUCESP No. [número]

j) Selo seco ou na forma de adesivo do tradutor público: constam tanto um selo seco rubricado em todas as páginas da tradução, quanto um selo adesivo afixado ao lado da assinatura do tradutor.

k) Carimbo do tradutor no verso do documento original: não

\section{Tradução intersemiótica}

O tradutor 7 optou por descrever os brasões, autenticações e assinaturas, conforme segue:

A- Brasão do Estado de São Paulo: [Coat of Arms - State of São Paulo] 
B- Carimbo da Escola: [Stamp - E.E. - Maria Trujilo Torloni - U.A. 41.188 - SD 02.231 Estrada das Lágrimas, 579 - B. São José - CEP: 09581-300 - Tel: 4238-7686 / S.C. Sul]

C- Autenticação da cópia: [Stamp - $17^{\text {th }}$ Notary Public Office - Jussara Citroni Modaneze Praça da Liberdade - No. 84/86 - São Paulo - State of São Paulo - 10/02/2012 - I do hereby CERTIFY that this photocopy is extract of its respective originals. I do certify to it. - Tiago de Almeida Pereira - Authorized Clerk - [Fees detail] - Valid only if bears the authenticity seal.]

[Authenticity seal - Association of Notary Publics of Brazil - State of São Paulo 1099AC580016]

[Initials]

D- Carimbo de emendas:

[Stamp - This document does not bear any erasures or amendments - Prepared by: [initials] Conferred by: [-]]

E- Assinaturas do Secretário e Diretor no documento: não mencionou a legibilidade da assinatura

[Signature]

[Stamp - Norimar Romano Arenghi - Brazilian Official Identity Card No. 6.688.015 - School Secretary]

\section{Notas do tradutor}

As notas explicativas foram apresentadas entre colchetes. A maioria referiu-se às traduções intersemióticas. Na menção da autenticidade da cópia, demonstrou uma tendência mais explicativa na inserção de informações extra-tradutórias.

\section{Perfil - destaque de tendências do tradutor após aplicação do modelo das modalidades de tradução.}

O percentual de omissão de 2,31\% do tradutor 7 foi o menor em seu grupo, bem como entre todos os tradutores observados, devido ao fato de o tradutor 7 ter traduzido a parte referente à transferência durante o período letivo, que não foi traduzida pela maioria dos tradutores por 
estar em branco no documento original. Por conseguinte, ocasionou um aumento no percentual de tradução palavra por palavra (31,57\%), maior que as médias do grupo de 1978 (22,83\%) e do grupo de 1998 (24,24\%), em virtude da repetição do quadro das disciplinas. Outro percentual elevado em relação ao seu grupo, foi observado na explicitação com 7,43\%, também o maior índice, comparando-se as duas gerações de tradutores. A explicitação ocorreu principalmente na tradução de siglas e resoluções ou artigos de leis, como em Res. SE 345 - DOE 10/12/84 que foi traduzido por Resolution of SE [Education Department] 345 DOE [State Oficial Gazette] of 12/10/84; bem como no nome da escola, Escola Estadual "Maria Trujilo Torloni”, em que foi feito o empréstimo na tradução, seguido da explicitação: Escola Estadual "Maria Trujilo Torloni” [Maria Trujilo Torloni Public School]. Não apresentou erros na transcrição de notas e carga horária. Desse modo, considerando-se a apresentação geral e estratégias escolhidas na tradução, o tradutor 7 mostrou tendência para um perfil detalhista e conservador. 


\subsubsection{Ficha descritiva do perfil do Tradutor 8 - Grupo de 1998}

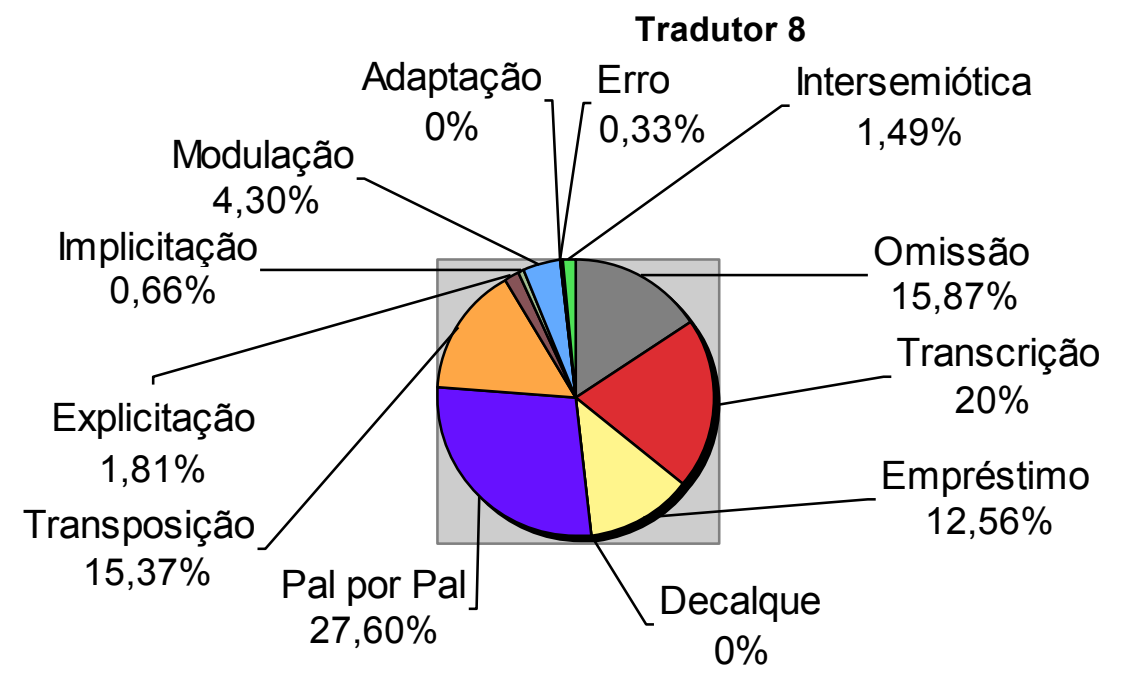

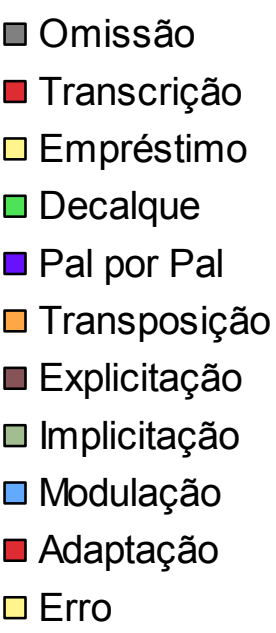

$\square$ Intersemiótica

\section{Apresentação da tradução - Aparência geral do documento impresso}

a) Papel timbrado do tradutor contém as informações completas exigidas pela deliberação do ofício: sim, porém, o tradutor seguiu as orientações contidas no site da junta comercial na época da posse.

b) Uso do Brasão da República Federativa do Brasil: sim, na cor azul, à margem esquerda do cabeçalho

c) Cor do papel e impressão: papel branco e impressão a laser tinta preta; cabeçalho na cor azul; tradução com total de três páginas grampeadas

d) Uso de marca d'água: não

e) Número de tradução, livro e folhas: sim, em vernáculo:

$$
\text { Tradução } n^{\circ}-\text { Livro }^{\circ}-\text { Folha }^{\circ}
$$

f) Introito: genérico, sem especificar o tipo de documento ou título

I HEREBY CERTIFY that the text below is a translation of a document originally written in Portuguese and that, from now on, shall read as follows: 
g) Corpo do texto: texto no formato retrato, utilizou letra Times New Roman, porém em número menor que 12, alinhamento justificado e sem o uso do tracejado ao final dos parágrafos. Houve pouca variação no tamanho da letra, proporcionando boa leitura do texto. A tabela com as disciplinas e notas está clara e de fácil leitura. Não reproduziu todos os realces e negritos do original, destacando apenas o nome da estudante e o título do documento.

h) Fecho: os emolumentos foram mencionados na parte da assinatura

I FINALLY CERTIFY that, to the best of my knowledge, the above translation is true. In witness whereof, I have hereunto set my hand and seal. São Paulo, June $20^{\text {th }}, 2013$.

i) Assinatura com firma reconhecida: consta assinatura, porém sem reconhecimento de firma. Forneceu com a tradução uma folha avulsa contendo o endereço do cartório para o reconhecimento da firma. Abaixo da assinatura, consta:

\section{[nome] \\ Sworn Translator}

j) Selo seco ou na forma de adesivo do tradutor público: consta um selo adesivo com fitilho em verde e amarelo ao lado da assinatura do tradutor.

k) Carimbo do tradutor no verso do documento original: sim, com a informação do número da tradução apenas

\section{Tradução intersemiótica}

O tradutor 8 optou por descrever os brasões, autenticações e assinaturas da seguinte forma:

A- Brasão do Estado de São Paulo: (Coat of Arms of the State of São Paulo)

B- Carimbo da Escola: (Stamp containing address and contact information of the School) 
C- Autenticação da cópia: (There are two stamps legalizing the document as a true copy, set by the $17^{\text {th }}$ Notary Public's Office under the authenticity seals 1099AC580017 AND 1099AC580016.)

D- Carimbo de emendas:

(Stamp) This document contains neither amendments nor erasures. Prepared by (illegible signature)

E- Assinaturas do Secretário e Diretor no documento: mencionou a legibilidade da assinatura (illegible signature) Norimar Romano Arenghi - RG (Identity Card) 6.688.015 - School Secretary

\section{Notas do tradutor}

As notas explicativas foram apresentadas entre parênteses. Na menção da autenticidade da cópia, demonstrou uma tendência mais objetiva na inserção de informações extra-tradutórias. Outro exemplo dessa objetividade, foi a indicação de (blank table) para o quadro em branco, em vez da inserção de uma nota de tradutor completa referente à omissão.

\section{Perfil - destaque de tendências do tradutor após aplicação do modelo das modalidades de tradução.}

O tradutor 8 apresentou um baixo percentual de explicitação 1,82\%, o que pode indicar uma tendência à objetividade. Pode-se observar, também, na menção da autenticidade da cópia, a opção por não detalhar ou traduzir na íntegra as informações. Nesse caso, foi apenas citada a existência de dois carimbos de cópia autenticada: (There are two stamps legalizing the document as a true copy, set by the $17^{\text {th }}$ Notary Public's Office, under the authenticity seals ...). Com relação às omissões $(15,87 \%)$, não foram utilizadas notas do tradutor, mas simplesmente a inserção de (blank table), como forma de justificar os campos em branco que não foram traduzidos. A única sigla com explicitação foi a do Diário Oficial, DOE acompanhada da explicação (Official Gazette of the State Government), as demais foram traduzidas por empréstimo. Observamos elevado percentual da modalidade palavra por palavra (27,60\%), acima das médias dos dois grupos, 1978 (22,83\%) e 1998 (24,24\%). Todavia, algumas palavras traduzidas literalmente, mostraram-se não serem as mais 
adequadas, tais como na tradução da legenda de notas, de menções por mentions e conceitos por concepts, casos em que alguns tradutores optaram por traduzir como grading scale ou letter grades. Não apresentou erros na transcrição de notas e carga horária. Desse modo, considerando-se a apresentação geral da tradução, bem como as estratégias escolhidas na tradução, o tradutor 8 mostra tendência a ter um perfil mais objetivo e prático. 


\subsubsection{Ficha descritiva do perfil do Tradutor 9 - Grupo de 1998}

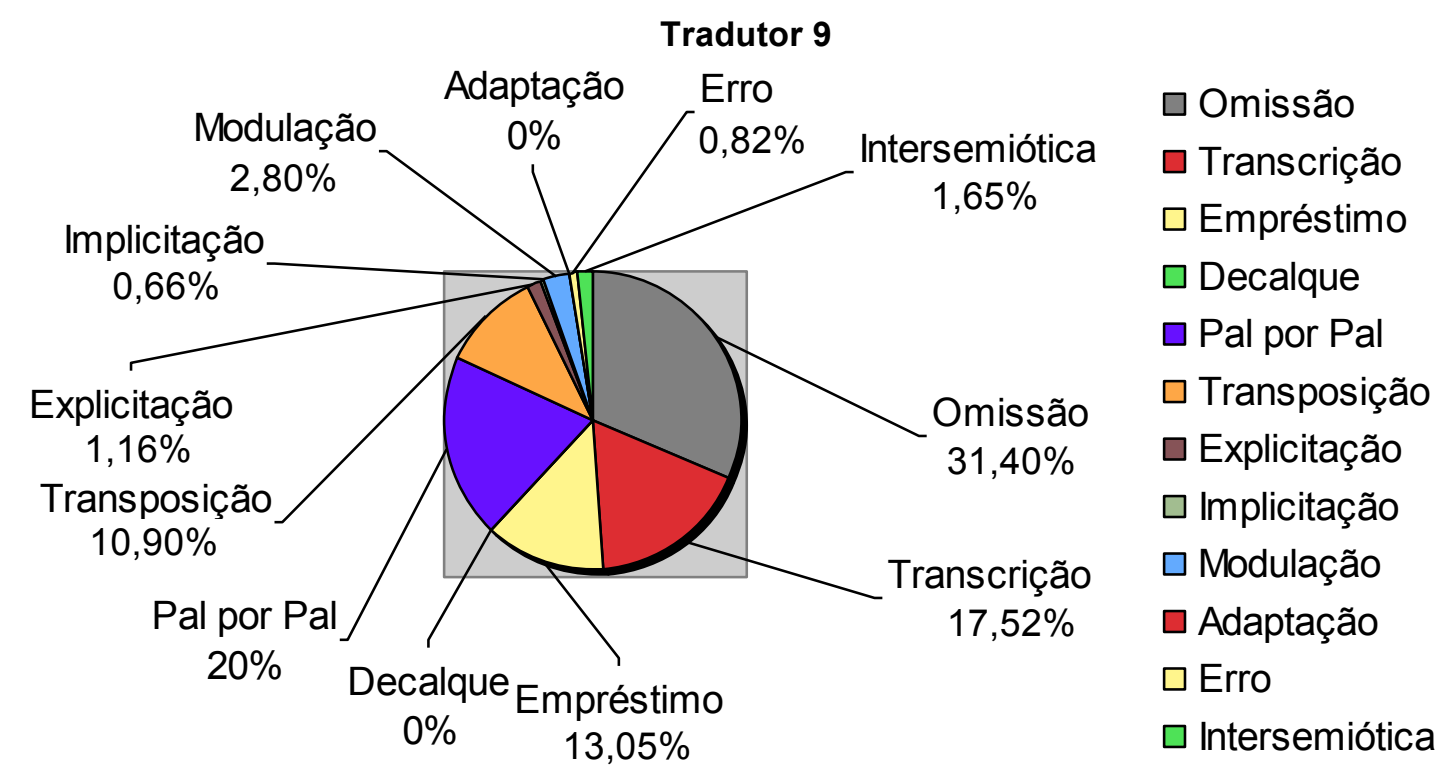

\section{Apresentação da tradução - Aparência geral do documento impresso}

a) Papel timbrado do tradutor contém as informações completas exigidas pela deliberação do ofício: sim, porém, o tradutor seguiu as orientações contidas no site da junta comercial na época da posse. O cabeçalho possui informação adicional do número do INSS não solicitada na deliberação, tampouco no site.

b) Uso do Brasão da República Federativa do Brasil: sim, colorido, à margem direita do cabeçalho

c) Cor do papel e impressão: papel em verde claro e impressão a laser tinta preta; cabeçalho impresso na cor verde; tradução com total de duas páginas soltas

d) Uso de marca d'água: não

e) Número de tradução, livro e folhas: consta apenas o número da tradução

f) Introito: genérico, sem especificar o tipo de documento ou título

I, the undersigned, [Name], Certified Sworn Translator, do hereby certify this is a faithful translation of a document submitted to me in Portuguese. 
g) Corpo do texto: texto no formato retrato, utilizou letra Times New Roman, porém em número menor que 12, alinhamento justificado e sem o uso do tracejado ao final dos parágrafos. Houve variação no tamanho da letra, entretanto, não prejudicou a boa leitura do texto. A tabela com as disciplinas e notas está clara e simplificada. Não reproduziu todos os realces e negritos do original, destacando apenas o nome da estudante, o título do documento, bem como algumas disciplinas e notas totais.

h) Fecho: os emolumentos não foram mencionados e houve um erro na grafia do mês, conforme segue:

Nothing else. Witness my hand and seal of office. São Paulo, Brazil, Jully 26, 2013.

i) Assinatura com firma reconhecida: consta assinatura, porém sem reconhecimento de firma. Abaixo da assinatura, consta apenas:

[nome]

Certified Sworn Translator

j) Selo seco ou na forma de adesivo do tradutor público: constam tanto o selo seco ao lado da assinatura do tradutor, quanto um selo adesivo à margem superior esquerda da primeira página do documento

k) Carimbo do tradutor no verso do documento original: sim, com a informação do número da tradução apenas

\section{Tradução intersemiótica}

O tradutor 9 optou por mencionar os brasões, autenticações e assinaturas, com a omissão de um item, conforme segue:

A- Brasão do Estado de São Paulo: (Coat of Arms of the State of São Paulo)

B- Carimbo da Escola: omitiu 
C- Autenticação da cópia: (Authentication stamp No. 1074AB459469)

(Copy certified true and correct on Oct 04, 2012, by Veronica Silva Araujo do Rosário, Authorized Clerk of the $2^{\text {nd }}$ Subdistrict - Liberdade Civil Registry Office.)

D- Carimbo de emendas: não mencionou a palavra carimbo. Traduziu o conteúdo:

This document does not contain any amendment and/or erasure.

Done by: (illegible)

E- Assinaturas do Secretário e Diretor no documento: não mencionou a legibilidade da assinatura e omitiu o número do RG do referido secretario (sgd.) Norimar Romano Arenghi, School Secretary (omitiu)

\section{Notas do tradutor}

As notas explicativas foram apresentadas entre parênteses. Na menção da autenticidade da cópia, demonstrou tendência mais objetiva na inserção de informações extra-tradutórias.

\section{Perfil - destaque de tendências do tradutor após aplicação do modelo das modalidades de tradução.}

O percentual de omissão $(31,40 \%)$ do tradutor 9 foi acima da média de seu grupo de 1998 (20,79\%), bem como do grupo de 1978 (22,20\%). O tradutor 9 omitiu a parte final reservada para uso da escola, além da parte referente à transferência durante o período letivo. De fato, foi o segundo maior percentual de omissão em comparação com os tradutores de 1978, e o maior no grupo ao qual pertence. Apesar desse elevado percentual, o tradutor 9 não demonstrou a preocupação em esclarecer as referidas omissões por meio de notas do tradutor. Sendo assim, os percentuais relativos à transcrição $(17,52 \%)$ e palavra por palavra $(20 \%)$ ficaram, abaixo das médias, respectivamente, do grupo de 1978 (18,73\%) e $1998(19,53 \%)$ para transcrição, e 1978 (22,83\%) e 1998 (24,24\%) para a modalidade palavra por palavra. De certo modo, seguindo uma tendência à objetividade observada em sua geração, com relação à modalidade de explicitação, o percentual foi de 1,16\%, o segundo menor em seu grupo. Não apresentou erros na transcrição de notas e carga horária. Desse modo, considerando-se a apresentação geral da tradução, elaborada de forma clara e concisa, bem como as estratégias escolhidas na tradução, o tradutor 9 mostra tendência a ter um perfil mais objetivo e prático. 


\subsubsection{Ficha descritiva do perfil do Tradutor 10 - Grupo de 1998}

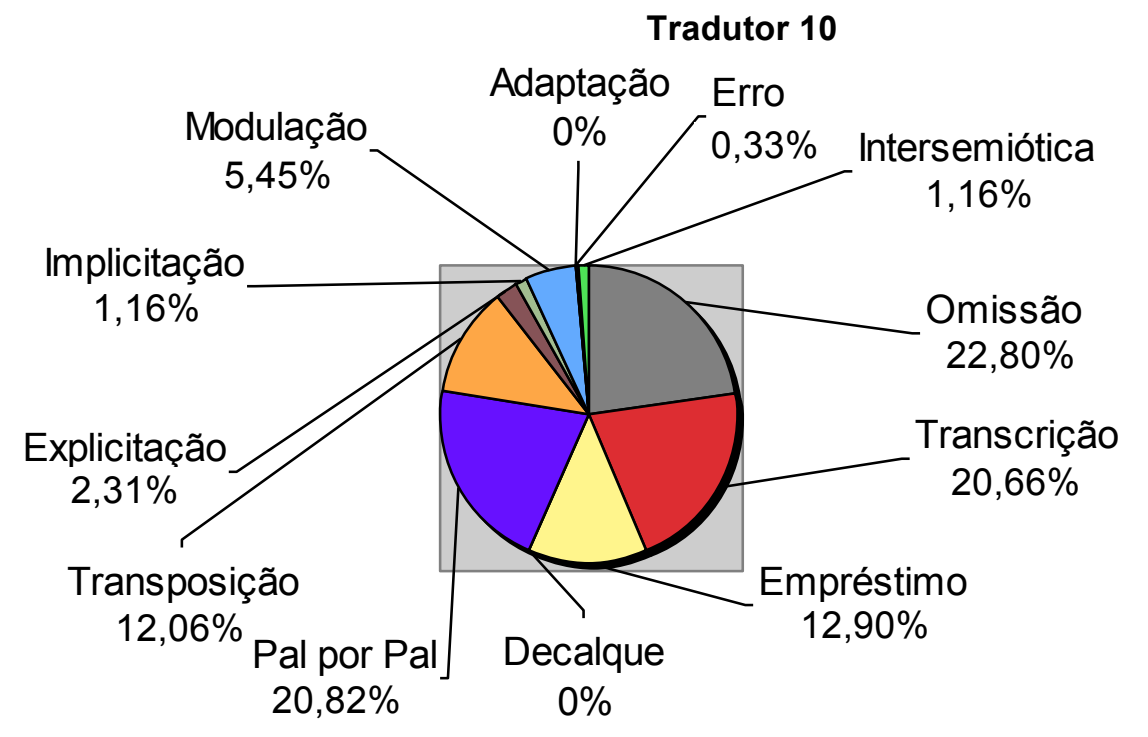

Omissão

Transcrição

$\square$ Empréstimo

$\square$ Decalque

$\square$ Pal por Pal

$\square$ Transposição

$\square$ Explicitação

$\square$ Implicitação

$\square$ Modulação

Adaptação

$\square$ Erro

$\square$ Intersemiótica

\section{Apresentação da tradução - Aparência geral do documento impresso}

a) Papel timbrado do tradutor contém as informações completas exigidas pela deliberação do ofício: sim, porém, o tradutor seguiu as orientações contidas no site da junta comercial na época da posse. O cabeçalho possui informações além das exigidas na deliberação.

b) Uso do Brasão da República Federativa do Brasil: sim, colorido, à margem esquerda do cabeçalho

c) Cor do papel e impressão: papel reciclado e impressão a laser tinta preta; tradução com total de três páginas unidas com o selo adesivo do tradutor

d) Uso de marca d'água: não

e) Número de tradução, livro e folhas: sim, em vernáculo:

$$
\text { Livro - Tradução Oficial - Página }
$$

f) Introito: genérico, sem especificar o tipo de documento ou título. O introito está redigido em vernáculo e em língua inglesa: 
I, [Name], Official Translator and Interpreter, hereby certify that a document in the Portuguese language was submitted to me, which by virtue of my office, I translate into English as follows:

g) Corpo do texto: texto no formato retrato, utilizou letra Times New Roman 12, alinhamento justificado e sem o uso do tracejado ao final dos parágrafos. Houve pouca variação no tamanho da letra, proporcionando boa leitura do texto. A tabela com as disciplinas e notas está clara, de fácil leitura e semelhante ao documento original. O tradutor reproduziu a maioria dos realces e negritos do original.

h) Fecho: os emolumentos foram mencionados na parte da assinatura

Nothing further. The foregoing is true, which I certify. São Paulo, July 16, 2013.

i) Assinatura com firma reconhecida: consta assinatura, porém sem reconhecimento de firma. Abaixo da assinatura, consta:

[nome]

Tradutor Público Juramentado

j) Selo seco ou na forma de adesivo do tradutor público: constam tanto um selo seco, quanto um selo adesivo com fitilho verde e amarelo afixado ao lado da assinatura do tradutor, bem como o selo adesivo do tradutor unindo as páginas do documento

k) Carimbo do tradutor no verso do documento original: sim, com a informação do número da tradução apenas

\section{Tradução intersemiótica}

O tradutor 10 optou por descrever os brasões, autenticações e assinaturas, conforme abaixo:

A- Brasão do Estado de São Paulo: [Coat of Arms of the State of São Paulo.]

B- Carimbo da Escola: [Stamp of E.E. Maria Trujilo Torloni] 
C- Autenticação da cópia: observamos um erro de concordância

[Both faces of the document bears the stamp of the Registrar of Vital Statistics $-2^{\text {nd }}$ Subdistrict of Liberdade, SP - Capital, on October $4^{\text {th }}, 2012$, duly signed by Verônica Silva Araujo do Rosario, Authorized Clerk. There are also two authenticity seals numbers 1074AB459463 and 1074AB459464].

D- Carimbo de emendas:

[Stamp:] This document has no amendments or erasures. Prepared by (sgd.) - Checked by [blank].

E- Assinaturas do Secretário e Diretor no documento: não mencionou a legibilidade da assinatura

Norimar Romano Arenghi

ID [RG]: 6.688 .015

School Registrar

\section{Notas do tradutor}

As notas explicativas foram apresentadas entre colchetes. Na menção da autenticidade da cópia, demonstrou uma tendência mais explicativa na inserção de informações extratradutórias. Inseriu nota referente aos campos em branco:

[Translator's Note: the blank and/or inapplicable items were not translated.]

\section{Perfil - destaque de tendências do tradutor após aplicação do modelo das modalidades de tradução.}

O percentual de omissão $(22,80 \%)$ do tradutor 10 não foi o mais elevado em seu grupo, porém ficou acima da média (20,79\%). Mostrou pouca tendência à explicitação (2,31\%) se compararmos com a média do grupo da geração anterior (4,04\%), entretanto, em seu grupo, permaneceu próximo à média $(2,50 \%)$. A explicitação pode ser verificada em exemplos como o RG, que foi traduzido por ID Card [RG], a Deliberação CEE N ${ }^{0}$ 04/95 traduzida por State Education Board [CEE] Decision 04/95, bem como o nome da escola, caso em que optou pelo empréstimo seguido por explicitação, na forma Escola Estadual "Maria Trujilo Torloni" 
[State School "Maria Trujilo Torloni]. O percentual de modulação (5,45\%) foi o mais elevado em seu grupo, e a título de exemplo, destacamos as traduções de Educação Artística por Arts, menções por grades e a palavra conceito (na legenda explicativa das notas) por meaning. Não apresentou erros na transcrição de notas e carga horária. Desse modo, considerando-se a apresentação geral da tradução, elaborada de forma clara e concisa, bem como as estratégias escolhidas, o tradutor 10 mostra tendência a ter um perfil objetivo moderado, com o uso de notas do tradutor no início da tradução para justificar omissões ou campos inaplicáveis do documento original. 


\subsubsection{Ficha descritiva do perfil do Tradutor 11 - Grupo de 1998}

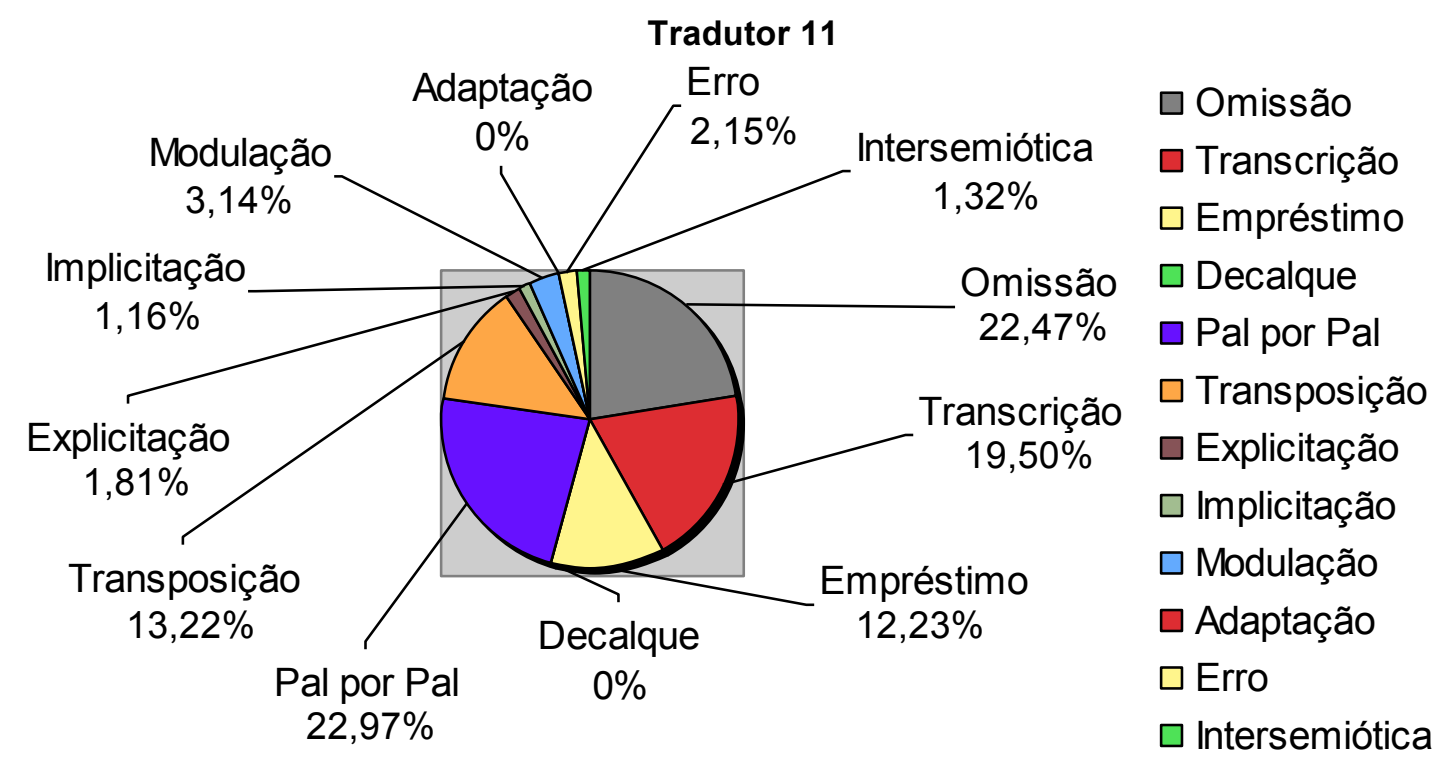

\section{Apresentação da tradução - Aparência geral do documento impresso}

a) Papel timbrado do tradutor contém as informações completas exigidas pela deliberação do ofício: sim, porém, o tradutor seguiu as orientações contidas no site da junta comercial na época da posse. O cabeçalho possui informação adicional do número do INSS não solicitada na deliberação, tampouco no site.

b) Uso do Brasão da República Federativa do Brasil: não

c) Cor do papel e impressão: papel branco e impressão a laser tinta preta; tradução com total de três páginas unidas com o selo adesivo do tradutor e fitilho em verde e amarelo

d) Uso de marca d'água: não

e) Número de tradução, livro e folhas: sim, em vernáculo:

$$
\text { TRADUÇÃO № - LIVRO № - FLS. }
$$

f) Introito: detalhado com a descrição do tipo do documento original

I, the undersigned Certified Translator for the English, German and Portuguese languages, certify and acknowledge the receipt of a document in Portuguese, which I identify as a certified copy of a School Record, which I translate into English, to the best of my knowledge and belief, as follows: 
g) Corpo do texto: texto no formato retrato, não utilizou letra Times New Roman 12, alinhamento justificado e sem o uso do tracejado ao final dos parágrafos. Houve grande variação no tamanho das letras, o que tornou um pouco cansativa a leitura do texto. A tabela com as disciplinas e notas está clara e bem semelhante ao original. O tradutor reproduziu todos os realces e negritos do original.

h) Fecho: os emolumentos foram mencionados após a assinatura, à margem inferior direita do documento

NOTHING ELSE was written on the document above, which I return with this translation typed in three pages, that I have checked, found in accordance and hereby sign. São Paulo, July $1^{\text {st }}, 2013$.

i) Assinatura com firma reconhecida: consta assinatura, porém sem reconhecimento de firma. À margem inferior do documento, consta endereço para reconhecimento da firma. Abaixo da assinatura, segue o teor:

[nome]

À margem inferior: R\$ 175,00 cf. Del. JUCESP N ${ }^{0}$ 05, de 19/06/2012

j) Selo seco ou na forma de adesivo do tradutor público: constam tanto o selo seco rubricado, em todas as páginas da tradução, quanto um selo adesivo com fitilho em verde e amarelo unindo as páginas da tradução.

k) Carimbo do tradutor no verso do documento original: sim, com a informação do número da tradução apenas

\section{Tradução intersemiótica}

O tradutor 11 optou por descrever os brasões, autenticações e assinaturas, conforme segue:

A- Brasão do Estado de São Paulo: [coat of arms of the State of São Paulo] 
B- Carimbo da Escola: [School rubber stamp]

C- Autenticação da cópia: [rubber stamp: notarial authentication attesting this xerographic copy to be a true copy of the original document. Register Office Liberdade - São Paulo, on Oct. $4^{\text {th }} 2012$, over authentication sticker]

D- Carimbo de emendas:

[rubber stamp]: This document is free of erasures or amendments.

Made by [illegible signature]

Conferred by

E- Assinaturas do Secretário e Diretor no documento: mencionou a legibilidade da assinatura: [signature illegible]

Norimar Romano Arenghi

ID 6.688 .015

\section{Notas do tradutor}

As notas explicativas foram apresentadas entre colchetes. Tanto na menção da autenticidade da cópia quanto dos campos em branco, demonstrou tendência mais objetiva na inserção de informações extra-tradutórias.

[rubber stamp: notarial authentication attesting the xerographic copy to be a true copy of the original document. Register Office Liberdade - São Paulo, on Oct. $4^{\text {th }} 2012$, over authentication sticker]

[The fields 50 to 56 and 90 to 93 were not translated because there is no registration on them]

\section{Perfil - destaque de tendências do tradutor após aplicação do modelo das modalidades de tradução.}

O tradutor 11 apresentou menor tendência à explicitação, apresentando o percentual de 1,81\% em seu grupo, cuja média foi de $2,50 \%$, considerado baixo também ao compararmos com a média do grupo da geração anterior (4,04\%). O percentual de omissão $(22,47 \%)$ do tradutor 11 não foi o mais elevado em seu grupo, porém ficou acima da média (20,79\%). Apesar de 
não apresentar erros na transcrição de notas e carga horária, observamos um percentual da modalidade de erro mais elevado $(2,15 \%)$, tanto em seu grupo quanto na geração anterior. A título de exemplo, houve inadequação na concordância verbal da frase the name of the student's parents are not mentioned; na grafia em comon core, em vez de common core, e na parte referente aos estudos realizados, o tradutor provavelmente confundiu-se ao traduzir o município da escola S.C. Sul por São Paulo em vez de São Caetano do Sul. Sendo assim, considerando-se a apresentação geral da tradução, bem como as estratégias escolhidas, o tradutor 11 mostra tendência a ter um perfil objetivo. 


\subsubsection{Ficha descritiva do perfil do Tradutor 12 - Grupo de 1998}

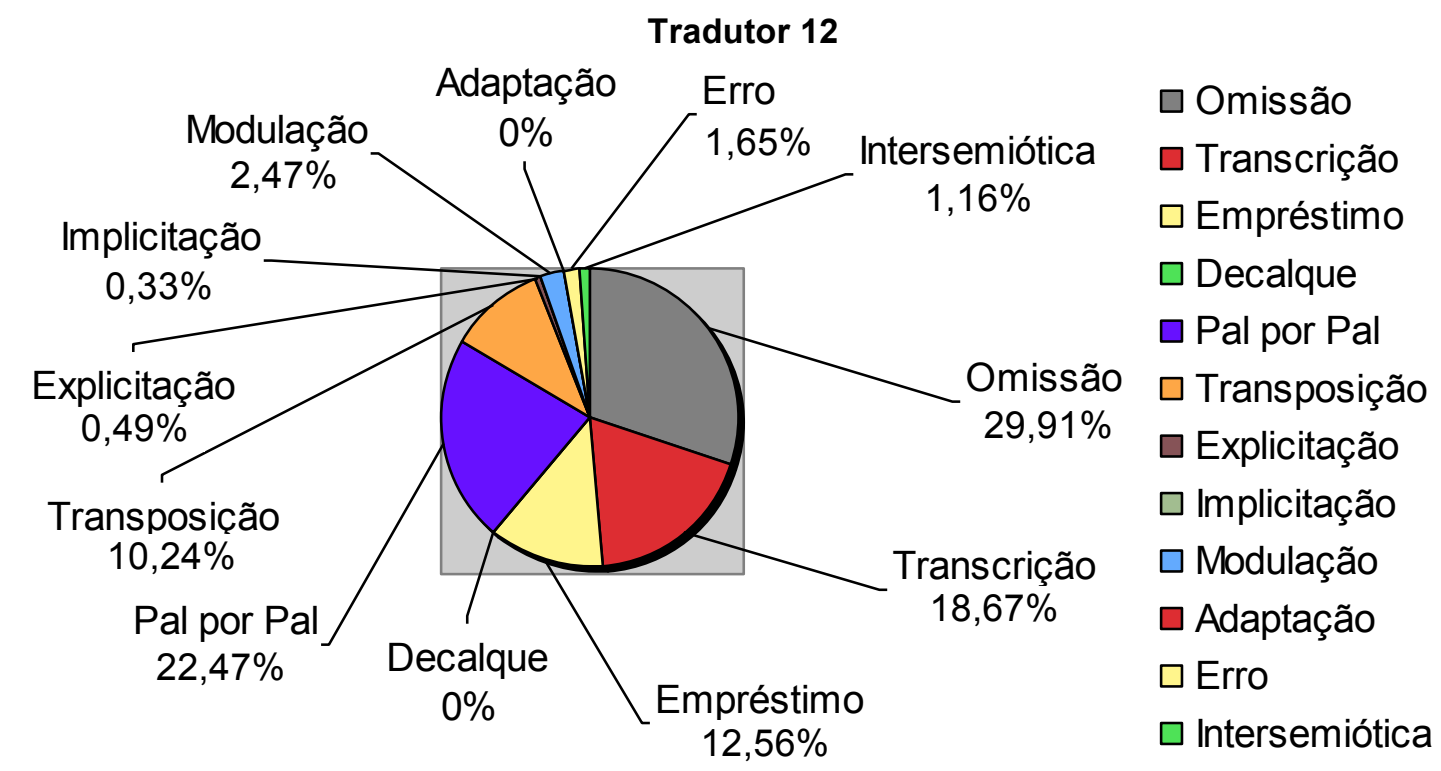

\section{Apresentação da tradução - Aparência geral do documento impresso}

a) Papel timbrado do tradutor contém as informações completas exigidas pela deliberação do ofício: sim, porém, o tradutor seguiu as orientações contidas no site da junta comercial na época da posse. O cabeçalho possui informações além das exigidas na deliberação.

b) Uso do Brasão da República Federativa do Brasil: sim, na marca d’água

c) Cor do papel e impressão: papel branco e impressão a laser tinta preta; tradução com total de três páginas unidas pelo selo adesivo do tradutor. Houve uma falha na impressão, que prejudicou a leitura de um disciplina e respectivas notas.

d) Uso de marca d'água: sim, com o Brasão da República Federativa do Brasil na cor cinza

e) Número de tradução, livro e folhas: sim, em vernáculo:

$$
\text { TRADUÇÃO N }{ }^{\circ}-\text { LIVRO N }^{\circ}-\text { FOLHAS N }
$$

f) Introito: genérico, sem descrever o tipo de documento original

I, [NAME], a Sworn Translator and Commercial Interpreter for the English language, duly sworn by the Board of Trade of the State of São Paulo - Federative Republic of Brazil, DO HEREBY CERTIFY that a document issued in the PORTUGUESE language was submitted to me, which I faithfully translated into ENGLISH, as follows: -.- 
g) Corpo do texto: texto no formato retrato, utilizou letra Times New Roman 12, alinhamento justificado e com o uso de ponto ao final de todas as linhas, inclusive nos itens. Houve variação no tamanho da letra, fato que não prejudicou a boa leitura do texto. A tabela com as disciplinas e notas está clara, bem semelhante ao documento original, excetuando-se a parte em que houve falha na impressão com superposição de letras. O tradutor não reproduziu todos os realces e negritos do original, optou por destacar o título do documento e as notas do tradutor.

h) Fecho: os emolumentos não foram mencionados

NOTHING FURTHER WAS CONTAINED IN THE DOCUMENT SUBMITTED.

I verified it and certify to it.

The Sworn Public Translator.

São Paulo, July 16, 2013.

i) Assinatura com firma reconhecida: consta assinatura com o reconhecimento de firma. Abaixo da assinatura, consta:

j) Selo seco ou na forma de adesivo do tradutor público: consta o selo adesivo do tradutor unindo as páginas do documento

k) Carimbo do tradutor no verso do documento original: sim, com a informação do número da tradução e do livro

\section{Tradução intersemiótica}

O tradutor 12 optou por mencionar os brasões, autenticações e assinaturas, com a omissão de um item, conforme segue:

A- Brasão do Estado de São Paulo: [Coat of Arms]

B- Carimbo da Escola: omitiu 
C- Autenticação da cópia: [The document bears two authentications duly signed and two authentication seals duly numbered.]

D- Carimbo de emendas: não mencionou a palavra carimbo. Traduziu o conteúdo:

This document does not contain erasures or amendments.

Elaborated by: [initials].

E- Assinaturas do Secretário e Diretor no documento: mencionou a legibilidade da assinatura Signed: [illegible signature].

Name: Norimar Romano Arenghi.

Title: School Secretary.

"RG": 6.688.015.

\section{Notas do tradutor}

As notas explicativas foram apresentadas entre colchetes. Na menção da autenticidade da cópia, demonstrou uma tendência mais objetiva na inserção de informações extra-tradutórias, sem citar detalhes da autenticação. Inseriu uma nota referente ao sistema educacional brasileiro, todavia, estava relacionada aos Estados Unidos em vez do Canadá, país mencionado como destino da tradução solicitada.

[Translator's Note ${ }^{1}$ : In the Brazilian Educational System, the Elementary Middle and High Schools are divided in twelve grades, named $1^{\text {st }}, 2^{\text {nd }}, 3^{\text {rd }}, 4^{\text {th }}, 5^{\text {th }}, 6^{\text {th }}, 7^{\text {th }}, 8^{\text {th }}$ and $9^{\text {th }}$ Grades and $1^{\text {st }}, 2^{\text {nd }}$ and $3^{\text {rd }}$ Years, which are respectively equivalente to the $2^{\text {nd }}, 3^{\text {rd }}, 4^{\text {th }}, 5^{\text {th }}, 6^{\text {th }}, 7^{\text {th }}, 8^{\text {th }}, 9^{\text {th }}$, $10^{\text {th }}, 11^{\text {th }}$ and $12^{\text {th }}$ Grades of North-American Education.]

[Translator's Note $^{2}$ : blank fields and items considered as inapplicable were not translated by me.]

Perfil - destaque de tendências do tradutor após aplicação do modelo das modalidades de tradução.

Mostrou pouca tendência à explicitação, apresentando o percentual mais baixo $(0,49 \%)$ em seu grupo, cuja média foi de $2,50 \%$ e também ao compararmos com a média do grupo da geração anterior (4,04\%). O percentual de omissão $(29,91 \%)$ do tradutor 12 foi o segundo mais elevado em seu grupo, porém houve a inserção de nota do tradutor justificando os 
campos em branco ou inaplicáveis que não foram traduzidos. O percentual da modalidade de erro foi o segundo mais elevado (1,65\%), tanto em seu grupo quanto na geração anterior. Houve erros na transcrição de notas e carga horária, causados devido a um provável descuido na impressão da tradução, que foi entregue com a disciplina Sociology impressa sobreposta a Modern Foreign Language English, fato esse que prejudicou a leitura das referidas informações. Desse modo, considerando-se a apresentação geral da tradução, bem como as estratégias escolhidas, o tradutor 12 mostra tendência a ter um perfil objetivo moderado, com o uso de notas do tradutor para justificar omissões ou campos inaplicáveis do documento original.

\subsection{Resultados gerais (Modalidades)}

De modo geral, os tradutores demonstraram forte aderência à deliberação que rege o ofício do tradutor público e intérprete comercial. Os aspectos que conferem características de documento oficial foram, em grande parte, utilizados e respeitados, com ligeiras variações que, todavia, não comprometeram a finalidade e/ou as características da tradução juramentada.

Por exemplo, as informações apresentadas no papel timbrado referentes ao tradutor, ou o cabeçalho da tradução, como é mais comumente conhecido, estavam em conformidade com a deliberação na maioria das traduções do grupo de 1978, à exceção do Tradutor 3, que não inseriu seu respectivo endereço, conforme exigência. Nesse quesito, conforme mencionado anteriormente, havia duplicidade de informações por ocasião da posse do grupo de 1998, em virtude da apresentação de orientações no site da Jucesp em 17 de novembro de 2000. Os novos tradutores seguiram as referidas instruções do site para a confecção do papel timbrado, exceto o Tradutor 7 que não inseriu o número do CPF no cabeçalho.

A maioria demonstrou preocupação em conferir o caráter de oficialidade ao documento, mediante o uso do Brasão da República, que é opcional. Apenas 2 tradutores (Tradutor 4 e 5) no grupo de 1978 e um (Tradutor 11) do grupo de 1998 não o utilizaram. O recurso de marca d'água, muito comum em documentos oficiais, foi pouco utilizado, somente por dois (Tradutores 6 e 12), um de cada grupo. 
Apenas um tradutor (Tradutor 7) não apôs seu carimbo no verso do documento original com a anotação do número da tradução e do livro. Essa prática é comumente adotada pela maioria dos tradutores como forma de atrelar a tradução ao original, recurso que serve também como garantia de que aquele foi o documento apresentado para a execução do serviço de tradução, em vez de qualquer outro; bem como para facilitar a identificação da tradução, caso haja a necessidade futura de o cliente solicitar segundas vias. Todavia, foi curioso observar que, à exceção do Tradutor 12, nenhum tradutor entregou a tradução com o reconhecimento de firma. No grupo de 1998, o Tradutor 8 forneceu o endereço do cartório em uma folha avulsa e, na folha com o papel timbrado do Tradutor 11, constava à margem inferior, o endereço do cartório para o reconhecimento da firma. Esse ato realizado por tabelião, através de sua fé pública, confere ao documento maior segurança para as partes, pois garante a presunção de veracidade da assinatura aposta, a identidade do signatário e "ausência de ilegalidade flagrante no documento. Portanto, longe de ser uma burocracia, o reconhecimento de firma, em razão da segurança agregada pelo ato aos documentos particulares, não deve ser dispensado" (Isolan, 2009:1).

Ainda no tocante ao quesito aparência geral, ou quanto à "materialidade das versões" (Alves, 2005:69) e, considerando que, nessa tipologia textual de histórico escolar, o "lay-out comunica" (Alves, 2005:69), vários tradutores buscaram reproduzir a formatação original do texto, quase que na forma de um "espelho", principalmente a tabela referente às disciplinas e notas. Oito dos doze tradutores (Tradutores 5, 6, 7, 8, 9, 10, 11 e 12) retrataram com sucesso a formatação da tabela de disciplinas. Apenas dois (Tradutor 3 e 12) apresentaram um texto corrido no estilo cartorial, mais denso para leitura, com o uso do tracejado ou ponto ao final dos parágrafos.

Em documentos escolares, principalmente nas referidas tabelas, há notadamente uma predominância de números e/ou letras que representam notas e conceitos para as disciplinas cursadas, e que são classificados na modalidade de transcrição. Aproximadamente $20 \%$ do conteúdo do documento é constituído por transcrições, que somadas aos empréstimos (12\%), outra modalidade que também recai nessa categoria de manutenção ou cópia de dados, totalizam mais de 30\%. Dentro desse percentual, estão informações pertinentes à identificação do aluno, nome do estabelecimento de ensino, endereço (ou seja antropônimos e topônimos), notas e carga horária que, em conjunto com as disciplinas, bem como o grau concluído, constituem elementos essenciais à finalidade tradutória dessa tipologia textual. 
Em contrapartida aos $30 \%$ de transcrições e empréstimos, obtivemos $0 \%$ nas adaptações, devido à tipologia textual utilizada nesta pesquisa de Mestrado. Poderíamos, de certo modo, a partir desses dados, fazer uma comparação entre textos literários e pragmáticos em relação ao esforço dedicado e à necessidade de atenção redobrada nessas categorias. $\mathrm{Na}$ tradução de textos literários, por exemplo, as modalidades de modulação e adaptação destacam-se no grau de dificuldade para se atingir um bom resultado final, por requererem mais pesquisa e habilidade criativo-vocabular por parte do tradutor. Por outro lado, em textos pragmáticos, repletos de números, nomes e razões sociais, tais como balanços patrimoniais, procurações e históricos escolares, as transcrições e empréstimos sobrecarregam o esforço de concentração do tradutor. Haveria uma inversão de valores nessas categorias-chave quanto ao esforço e dedicação, por conta de sua frequência, comparando-se a tradução literária com a de textos pragmáticos. As modalidades significativas em uma tipologia seriam as de menor relevância na outra. Nesse comparativo ora sugerido, não estão incluídos os textos jurídicos que, em estudos anteriores, em especial, Zanotto (1993), indicam que traduções de textos jurídicos (na direção tradutória inglês para o português) tendem a apresentar índices de modulações em níveis similares aos das traduções de textos literários. Certamente, novos estudos seriam necessários para verificar essa possível comparação no tocante às transcrições e modulações/adaptações nas tipologias textuais sugeridas.

Logo, a transcrição errônea de informações pode comprometer, e muito, o propósito da tradução. Não apenas em relação a números, mas principalmente nomes e razões sociais. Erros podem impedir registros em órgãos pertinentes, retardar matrículas em instituições de ensino. Por exemplo, o instrumento de mandato, ou comumente chamado de procuração, contém grande quantidade de informações pessoais, tais como números de RG, CPF, CNPJ (Cadastro Nacional da Pessoa Jurídica), nomes de empresas. Essas informações de qualificação da pessoa, tanto física quanto jurídica, a quem foi feita a outorga de poderes, são essenciais e centrais no documento; em sua grande maioria, são classificadas na modalidade de tradução de transcrição ou empréstimo. Conforme ressalta Aubert (2012:14), "na tradução juramentada a identificação constitui um dos elementos essenciais de qualquer texto. Qualquer alteração pode invalidar o documento ou, ao menos, tornar a tradução inutilizável”.

Nesse sentido, destacamos a importância da revisão ou, ao menos, da conferência de nomes, números, principalmente nesse tipo de documento, haja vista a quantidade de dados dessa natureza e respectiva relevância na finalidade da tradução. A tarefa de revisão ou 
conferência é complementar ao ato tradutório e pode ser realizada ou não pelo próprio tradutor. Especialmente em documentos escolares, contábeis e financeiros, a revisão faz parte integrante da tradução, no sentido da verificação de nomes, números, devido à relevância e elevado volume de dados dessa natureza. Ao final do processo tradutório, é de praxe a releitura ou cotejo com o documento original pelo próprio tradutor, com a finalidade de eliminar possíveis omissões ou erros na transcrição de dados, quer por conta do cansaço ou realização da tarefa em um curto espaço de tempo. Entretanto, alguns profissionais preferem trabalhar em parceria com revisores para garantia da qualidade. Muitos escritórios possuem departamentos de conferência ou revisão.

Após o cotejo das transcrições, principalmente em relação a notas e cargas horárias, verificamos que a maioria dos tradutores não apresentou erros nesses quesitos, à exceção do Tradutor 4, com o percentual mais elevado de seu grupo (1,32\%), com 3 erros de transcrição (notas e carga horária); e o Tradutor 12, que entregou a tradução com falha na impressão, o que prejudicou a leitura das notas das disciplinas Sociologia e Língua Estrangeira Moderna (L.E.M.), por saírem sobrepostas.

No tocante ao número de ocorrências de omissão, o documento original contém uma parte extensa não preenchida e anulada por uma linha na diagonal, portanto, não aplicável, referente a informações sobre transferência durante o período letivo. Logo, era previsto que esse trecho seria omitido, como de fato, apenas dois tradutores (Tradutor 5 e 7) fizeram a tradução na íntegra dessa parte. Dentre os dez tradutores que o omitiram, seis apresentaram justificativa por meio de nota do tradutor ou mencionaram [blank], [not applicable], (blank table) ou (omissis), como podemos verificar a seguir:

Trecho do original: Transferência durante o período letivo

\begin{tabular}{lll}
\hline & Tradutor 1 & TRANSFER [blank] \\
Tradutor 2 & (omitiu) \\
Trupo & Tradutor 3 & $\begin{array}{l}\text { TRANSFER DURING SCHOOL PERIOD [not applicable] } \\
\text { (omitiu) }\end{array}$ \\
& Tradutor 4 & TRANSFER DURING THE SCHOOL YEAR \\
& Tradutor 5 & TRANSFER DURING THE SCHOOL PERIOD [N.T.] (com explicação) \\
\hline & Tradutor 6 & Transfer during the school year \\
& Tradutor 7 & TRANSFER DURING THE SCHOOL PERIOD (blank table) \\
Trupo & Tradutor 8 & (omissis) \\
1998 & Tradutor 9 & (omitiu) \\
& Tradutor 10 & (omitiu) \\
& Tradutor 11 & (omitiu) [N.T.] (com explicação)
\end{tabular}


Estatisticamente, os resultados da modalidade de omissão dispersaram-se entre 25,12\% (Tradutor 1), 25,61\% (Tradutor 2), 14,21\% (Tradutor 3), 43,63\% (Tradutor 4), 5,45\% (Tradutor 5) e 19,17\% (Tradutor 6) no Grupo de 1978, por exemplo, em virtude da decisão do tradutor em omitir ou não o referido trecho. O Tradutor 5 com 5,45\% e o Tradutor 7 (do grupo de 1998) com 2,31\% apresentaram os menores percentuais de omissão, por terem optado pela tradução integral. Em contrapartida, o Tradutor 4 destacou-se com o percentual mais elevado de $43,63 \%$, por ter se excedido na quantidade de omissões, além das previstas ou prováveis, de acordo com o teor do original.

Em geral, a estratégia adotada pelo tradutor, em relação a omissões, é guiada pela relevância ou pertinência da informação no contexto geral do documento. Por se tratar de tradução juramentada, observamos a inserção de nota do tradutor como uma forma de manter a segurança jurídica da tradução, assegurando que o trecho em branco foi observado, considerado e não traduzido, por conta da não relevância ou inaplicabilidade no documento.

Todavia, essa análise do tradutor quanto à relevância ou não de campos em branco no documento original para tradução, deve ser feita de maneira muito cautelosa, a fim de preservar a segurança jurídica do documento, como já mencionada sua importância anteriormente.

Ademais, outra característica comum em documentos escolares, é a anulação dos campos em branco referentes a notas. O histórico escolar que tomamos por base apresentou os campos de notas em branco anulados com o símbolo “|”. Dez tradutores de nossa amostra anularam os campos de notas em branco, com algumas variações de símbolos, a saber: “ -- ”, “. ", “/," “| " ou “[-]”.

Em nosso corpus de estudo, observamos também outras omissões realizadas pelos tradutores, além dos campos em branco ou inaplicáveis do documento original; ou seja, omissões eventuais, tais como a abreviação $(R M)$ para o registro de matrícula do aluno, omitida em 6 traduções. Os tradutores 4 e 9 não traduziram, por exemplo, partes da denominação da disciplina Língua Estrangeira Moderna - Inglês, que foi simplificada por apenas English, bem como itens explicativos da estrutura de ensino como Núcleo Comum e Parte Diversificada. Esses últimos, por se tratarem de elementos secundários, não causariam 
prejuízo à finalidade da tradução; todavia, podem indicar a tendência para um perfil mais objetivo ou sucinto por parte desses tradutores se comparados aos demais.

Sendo assim, destacamos a seguir, a título de exemplo, alguns dos itens mencionados no parágrafo anterior, que foram retirados do anexo composto pela lista de 158 itens, lista essa que apresenta um panorama das dispersões entre os doze tradutores. Todas as traduções estão apresentadas no citado anexo.

Trecho do original: Registro de Matrícula (RM) do Aluno

\begin{tabular}{lll}
\hline & Tradutor $\mathbf{1}$ & Student enrollment number \\
& Tradutor $\mathbf{2}$ & Enrollment \\
Grupo & Tradutor 3 & Student's Registration Number (RM) \\
1978 & Tradutor $\mathbf{4}$ & STUDENT REGISTRATION NUMBER \\
& Tradutor 5 & STUDENT ENROLLMENT NUMBER (RM) \\
& Tradutor 6 & Student's School Registration (RM) \\
\hline \multirow{3}{*}{ Trupo } & Tradutor 7 & Student's Enrollment Registry (RM) \\
1998 & Tradutor 8 & Student's Enrollment number \\
& Tradutor $\mathbf{9}$ & Enrollment No. \\
& Tradutor $\mathbf{1 0}$ & STUDENT'S ENROLLMENT No. \\
& Tradutor 11 & ENROLLMENT RECORD (RM) OF THE STUDENT \\
& Tradutor 12 & Enrollment Registry (RM) of the Student
\end{tabular}

No exemplo acima, destacamos em negrito os seis tradutores que omitiram a sigla (RM) e, logo abaixo, verificamos nos Tradutores 1, 4 e 9, outro exemplo de ocorrência de omissão por opção do tradutor, no caso do item Núcleo Comum, visto que o referido item não se refere a nenhum campo em branco ou inaplicável:

Trecho do original: Núcleo Comum

\begin{tabular}{|c|c|c|}
\hline & Tradutor 1 & (omitiu) \\
\hline & Tradutor 2 & Common Nucleus \\
\hline & Tradutor 3 & Core Curriculum \\
\hline \multirow{5}{*}{1978} & Tradutor 4 & (omitiu) \\
\hline & Tradutor 5 & Common Core \\
\hline & Tradutor 6 & CORE CURRICULUM \\
\hline & Tradutor 7 & Common Core \\
\hline & Tradutor 8 & COMMON NUCLEUS \\
\hline Grupo & Tradutor 9 & (omitiu) \\
\hline \multirow[t]{3}{*}{1998} & Tradutor 10 & Common Classes \\
\hline & Tradutor 11 & Comon Core \\
\hline & Tradutor 12 & Common Core \\
\hline
\end{tabular}

Houve uma ocorrência de erro, destacada em vermelho, provavelmente por falha na digitação. Nesse sentido, o Grupo de 1998 apresentou maior percentual de erros, com 1,02\% face a $0,41 \%$ do Grupo de 1978, na maioria, lapsos na digitação, tais como Escola por Scholl e o nome Volpom por Volpon. 
Quanto à modalidade de tradução palavra por palavra, a percentagem é similar nos dois grupos: 22,83\% (Grupo 1978) e 24,24\% (Grupo 1998), e representa o percentual mais elevado da amostra. Esses dados demonstram a tendência de a tradução juramentada "ser mais literalizante e estrangeirizadora, em virtude da sua especificidade e da expectativa, vinculada à fé pública, de produzir efeitos legais e espelhar a realidade extralinguística do documento original”, conforme Alves (2005:80). Todavia, devemos considerar que a tipologia textual utilizada na pesquisa pode ter influenciado ou colaborado com esse resultado. Históricos escolares, em geral são compostos por itens (disciplinas e notas) dispostos em tabelas, diferentemente, de textos jurídicos ou contratuais, que apresentam maior densidade textual. Possivelmente, os resultados seriam diferentes, mediante a utilização de textos jurídicos ou contratuais, amostras essas que podem vir a ser utilizadas em pesquisas futuras.

Nesse sentido, observamos percentuais menores para a modalidade de modulação, em ambos os grupos, sendo 5,04\% (1978) e 3,74\% (1998), assim como na pesquisa de Aubert, Barros e Delvizio (2010) com documentos acadêmicos, em que também foram encontrados poucos exemplos da modalidade de modulação. Os referidos autores concluem "que isso se deva ao compromisso do tradutor público em manter a maior proximidade possível com o texto de partida, permitindo comparações com este e o resgate de referências culturais, não sendo desejadas nesse contexto mudanças de referencialidade" (Aubert; Barros; Delvizio, 2010: 225).

Complementarmente, destacamos que os itens relativos às disciplinas foram traduzidos de forma satisfatória por todos os tradutores e, na modalidade de decalque, houve apenas duas ocorrências, com a adaptação gráfica das palavras José e Lágrimas sem o acento. Tanto no grupo de 1978 quanto no de 1998, os percentuais de transposições de 13,99\% e 13,77\%, respectivamente, ocuparam a quarta posição em relação as demais modalidades.

No tocante à explicitação, observamos uma maior tendência no grupo de 1978 (4,04\%) em comparação aos tradutores habilitados em 1998 (2,50\%), principalmente quanto ao esclarecimento de determinadas siglas. Houve maior flutuação nos trechos dos credenciamentos e autorizações para o funcionamento do estabelecimento escolar ou resoluções da Secretaria de Educação, conforme exemplos abaixo: 
Trecho do original: RES. CFE 06/86

\begin{tabular}{lll}
\hline & Tradutor 1 & Under Federal Board of Education resolution CFE No. 6/86 \\
& Tradutor 2 & Resolution No. 06/86 issued by the Federal Board of Education (CFE) \\
Trupo & Tradutor 3 & C.F.E. [Federal Council of Education] RESOLUTION NO. 06/86 \\
1978 & Tradutor 4 & (omitiu) \\
& Tradutor 5 & RES. CFE 06/86 \\
& Tradutor 6 & CFE RESOLUTION 06/86 \\
\hline \multirow{3}{*}{ Grupo } & Tradutor 7 & Resolution Federal Council of Education 06/86 \\
& Tradutor 8 & RES. CFE 06/86 \\
& Tradutor 9 & RES. CFE 06/86 \\
& Tradutor 10 & RES. CFE 06/86 \\
& Tradutor 11 & RES. CFE 06/86 \\
& Tradutor 12 & Res. CFE 06/86
\end{tabular}

Trecho do original: conforme RES. SE-12,

\begin{tabular}{|c|c|c|}
\hline \multirow{6}{*}{$\begin{array}{l}\text { Grupo } \\
1978\end{array}$} & Tradutor 1 & under Resolution SE-12, \\
\hline & Tradutor 2 & as per Resolution No. 12 issued by the State Department of Education (SE) \\
\hline & Tradutor 3 & as determined by SE [Secretariat of Education] RESOLUTION 12, \\
\hline & Tradutor 4 & in accordance with Resolution SE-12, \\
\hline & Tradutor 5 & pursuant to RES. SE-12, \\
\hline & Tradutor 6 & according to SE-12 Resolution, \\
\hline \multirow{6}{*}{$\begin{array}{l}\text { Grupo } \\
1998\end{array}$} & Tradutor 7 & $\begin{array}{l}\text { in accordance with the RES. SE-12 [Resolution of State Department of } \\
\text { Education] }\end{array}$ \\
\hline & Tradutor 8 & according to RES. SE-12, \\
\hline & Tradutor 9 & according to Res. SE-12, \\
\hline & Tradutor 10 & according to RES. SE-12, \\
\hline & Tradutor 11 & Pursuant to Resolution SE-12, \\
\hline & Tradutor 12 & in accordance with Res. SE-12, \\
\hline
\end{tabular}

Todavia, apesar da dispersão de soluções verificada, notamos maior homogeneidade nas soluções tradutórias apresentadas pelo grupo de 1998, nos exemplos acima apresentados, bem como para a versão de Parte Diversificada, a seguir:

Trecho do original: Parte Diversificada

\begin{tabular}{lll}
\hline & Tradutor 1 & DIVERSIFIED SYLLABUS \\
Trupo & Tradutor 2 & Diversified Part \\
1978 & Tradutor 3 & DIVERSIFIED PART \\
& Tradutor 4 & (omitiu) \\
& Tradutor 5 & DIVERSIFIED CURRICULUM \\
& Tradutor 6 & SUPPLEMENTARY CURRICULUM \\
\hline & Tradutor 7 & Diversified Part \\
Grupo & Tradutor 8 & DIVERSIFIED PART \\
1998 & Tradutor 9 & Diversified Part \\
& Tradutor 10 & Diversified Part \\
& Tradutor 11 & DIVERSIFIED PART \\
& Tradutor 12 & (omitiu)
\end{tabular}

Curioso destacar que, até em itens considerados simples como o RG, houve grande variação de soluções tradutórias. Pode-se compreender tal resultado com base na sugestão de 
Aubert (2005:263) de "uma certa correlação (que não há de ser absoluta, mas pode caracterizar-se como tendência) entre o maior ou menor grau de especificidade (singularidade) cultural e uma maior ou menor dispersão nas soluções propostas". Ou seja, quanto mais específico ou próprio de uma cultura um termo, maior será a probabilidade de obtermos várias traduções, conforme evidenciado nas soluções apresentadas a seguir:

Texto original: $\mathrm{RG} 26.220 .812-\mathrm{X}$

\begin{tabular}{lll}
\hline & Tradutor 1 & identity card No. RG 26220812-X \\
Grupo & Tradutor 2 & bearer of Personal I.D. Card (RG) 26.220.812-X \\
1978 & Tradutor 3 & [ID Card] R.G. No. 26,220,812-X \\
& Tradutor 4 & Identity Card RG N. 26.220.812-X \\
& Tradutor 5 & R.G. 26.220.812-X \\
& Tradutor 6 & Identity Card RG 26.220.812-X \\
\hline \multirow{3}{*}{ Grupo } & Tradutor 7 & Brazilian Official Identity Card No. 26.220.812-X \\
1998 & Tradutor 8 & RG (identity card) 26.220.812-X \\
& Tradutor 9 & ID card No. 26.220.812-X \\
& Tradutor 10 & ID Card [RG] No. 26.220.812-X \\
& Tradutor 11 & I.D card (R.G) No. 26.220.812-X \\
& Tradutor 12 & identity Card "RG" no. 26.220.812-X
\end{tabular}

Sendo assim, para uma melhor visualização dos resultados gerais, elaboramos o seguinte gráfico e observações, a partir dos dados estatísticos obtidos na pesquisa referente ao grupo de 1978:

\section{Distribuição das Modalidades de Tradução para Tradutores Habilitados em 1978}

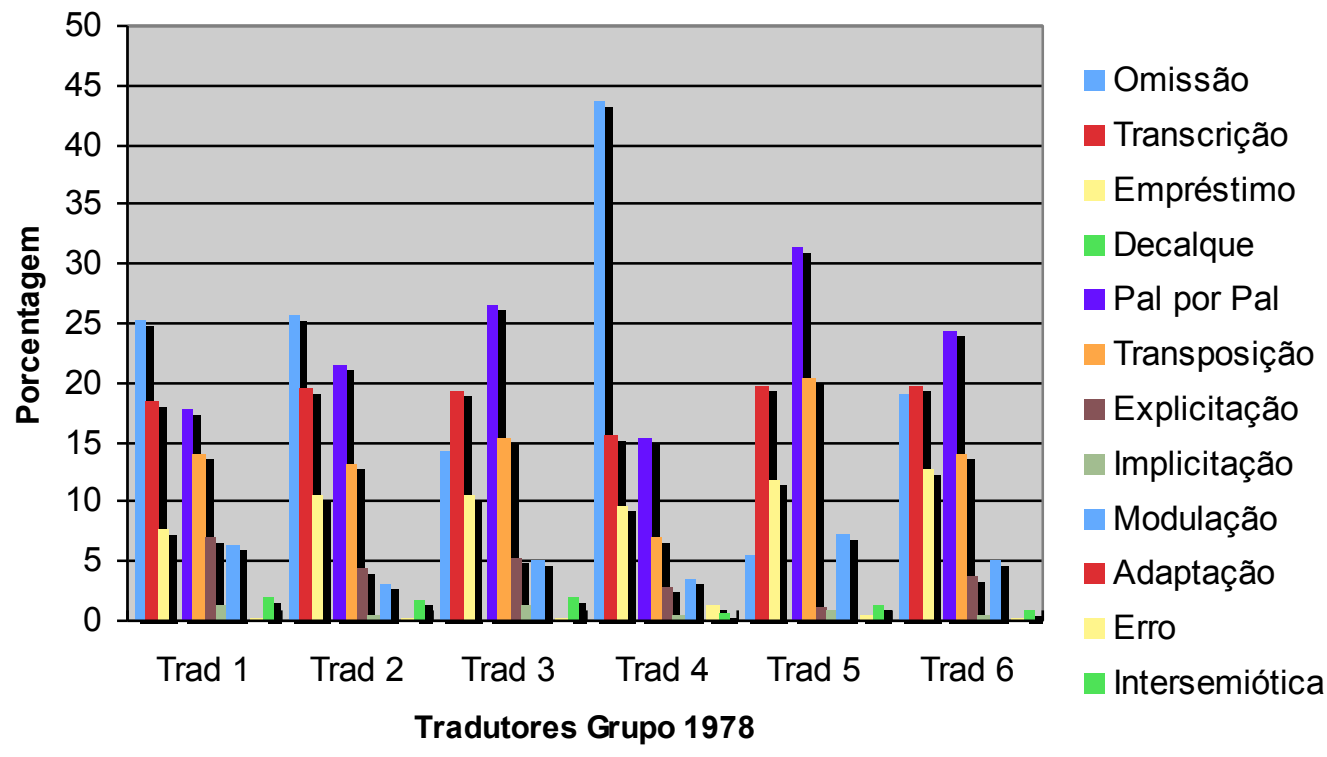

Gráfico 5.2.1 - Distribuição das Modalidades de Tradução para Tradutores Habilitados em 1978 
(i) as modalidades mais frequentes são a palavra por palavra $(22,83 \%)$, omissão $(22,20 \%)$, transcrição $(18,73 \%)$ e transposição $(13,99 \%)$;

(ii) na tipologia de documento escolar, mostra-se mais frequente a transcrição $(18,73 \%)$ do que a modulação $(5,04 \%)$;

(iii) os tradutores demonstraram maior tendência à explicitação $(4,04 \%)$ do que à implicitação $(0,74 \%)$;

(iv) não houve ocorrências para as modalidades de decalque e adaptação;

(v) o Tradutor 4 apresentou um percentual de quase $45 \%$ para omissões, destacando-se dos demais, inclusive quanto às características formais pertinentes à tradução juramentada, conforme anteriormente comentado;

(vi) as ocorrências de erro $(0,41 \%)$ no grupo em questão apresentaram-se dentro de uma média padrão aceitável; e

(vii) as modalidades das classes de espelhamento e literalidade (antigamente denominadas diretas) nessa tipologia de texto e direção tradutória português $\rightarrow$ inglês somam uma média superior a 70\%, o que pode constituir "um indicativo da viabilidade da tradução assistida por computador para esse par linguístico (Aubert, 1998:126).

Com relação ao grupo de 1998, podemos destacar no gráfico abaixo, as seguintes observações:

\section{Distribuição das Modalidades de Tradução para Tradutores Habilitados em 1998}

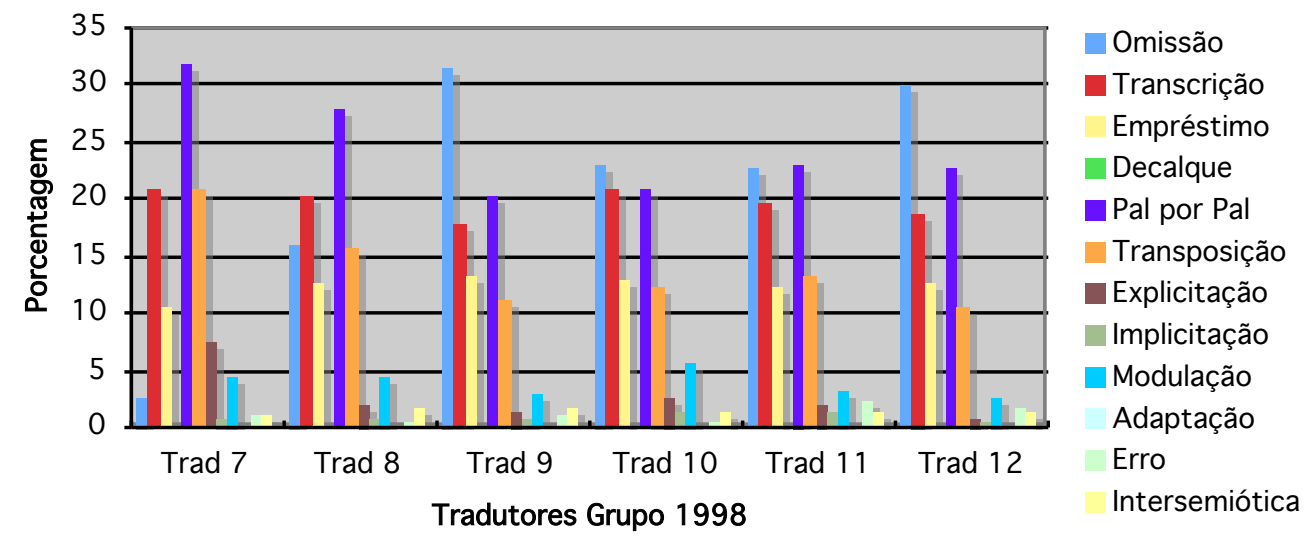

Gráfico 5.2.2 - Distribuição das Modalidades de Tradução para Tradutores Habilitados em 1998

(i) As modalidades mais frequentes também são a palavra por palavra $(24,24 \%)$, omissão (20,79\%), transcrição $(19,53 \%)$ e transposição $(13,77 \%)$; 
(ii) mostrou-se ainda mais acentuada neste grupo, a maior frequência de transcrições $(19,53 \%)$ do que de modulações $(3,74 \%)$;

(iii) os tradutores demonstraram maior tendência à explicitação $(2,50 \%)$ do que à implicitação $(0,74 \%)$

(iv) não houve ocorrências para a modalidades de adaptação e apenas duas para o decalque;

(v) o Tradutor 7 apresentou o menor percentual de omissões $(2,31 \%)$ e o maior na modalidade de explicitação $(7,43 \%)$, muito acima da média do grupo;

(vi) as ocorrências de erro (1,02\%) apresentaram-se com uma média mais elevada; e

(vii) as modalidades das classes de espelhamento e literalidade (antigamente denominadas diretas) nessa tipologia de texto e direção tradutória português $\rightarrow$ inglês somam uma média superior a $72 \%$.

Por fim, de modo a sintetizar os resultados da pesquisa sobre as modalidades de tradução aplicadas ao corpus de um documento original traduzido por doze tradutores públicos na direção tradutória português $\rightarrow$ inglês, apresentamos um gráfico comparativo entre as gerações, em que:

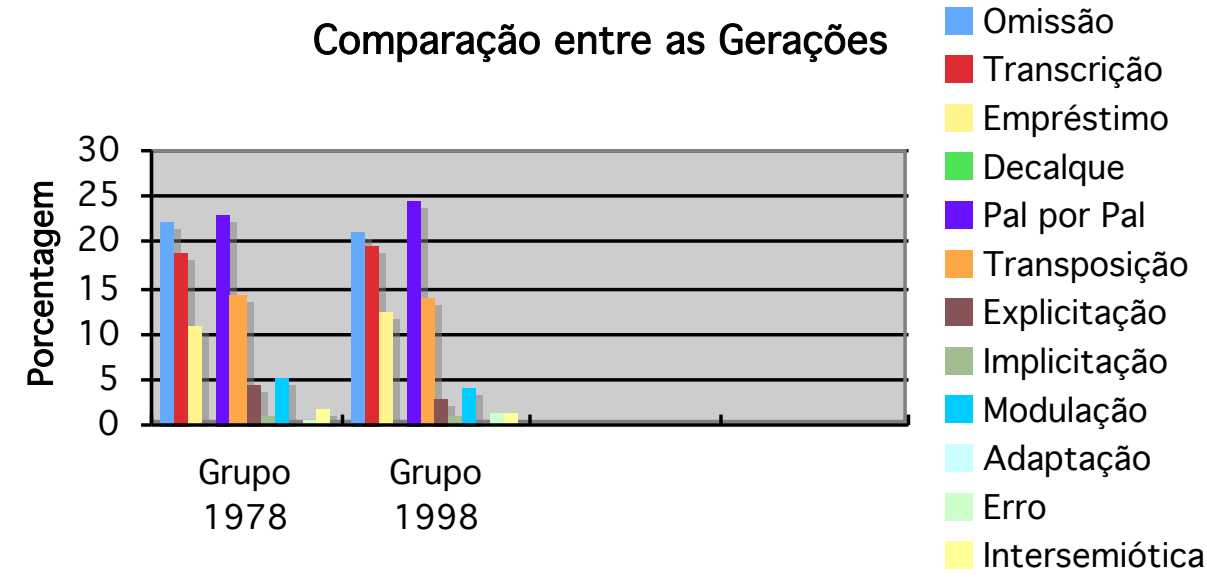

Gráfico 5.2.3 - Comparação entre as Gerações

(i) houve predominância da modalidade palavra por palavra nos dois grupos, 22,83\% para tradutores nomeados em 1978 e $24,24 \%$ para os nomeados em 1998;

(ii) a transcrição apresentou incidência elevada, bem como os empréstimos, o que aparentemente podem vir a ser marcadores da tradução de textos escolares e acadêmicos;

(iii) o grupo de 1978 mostrou maior frequência nas modalidades de omissão e modulação; 
(iv) as ocorrências de erro foram superiores no grupo de 1998 , em torno de $50 \%$ a mais que no grupo de 1978;

(v) não houve relevante oscilação na modalidade intersemiótica entre os grupos;

(vi) a modalidade de explicitação obteve maior destaque no grupo de 1978; e

(vii) as três principais modalidades de tradução, em ordem decrescente, são a palavra por palavra, omissão e transcrição para os dois grupos.

Em resumo, tendo em vista o acima exposto e as fichas individuais dos perfis dos doze tradutores, foi observada uma maior tendência ao perfil conservador e detalhista na geração de 1978 e o perfil mais objetivo no grupo de 1998. Na geração de 1978, quatro tradutores mostraram-se com tendências mais conservadoras e detalhistas (Tradutor 1, 2, 3 e 6) e dois objetivos (Tradutor 4 e 5). Por sua vez, no grupo de 1998, três tradutores (Tradutor 8, 9 e 11) apresentaram tendência objetiva, dois moderados (Tradutor 10 e 12) e apenas um tradutor (Tradutor 7) com tendência mais conservadora.

Em nossa pesquisa, o perfil conservador refere-se a uma postura de elevada aderência às normas e regulamentos, extrema preocupação com a segurança jurídica da tradução. Em geral, esse perfil poderá estar combinado ao detalhista, ao apresentar tendência à explicitação. Em contraste ao conservador, observamos o perfil objetivo, que se mostrou mais prático, direto e claro, principalmente na apresentação da tradução em geral, mediante o pouco uso de explicitações, entretanto, que manteve o cumprimento dos regulamentos e normas. Ao indicarmos a qualificação "moderado" no perfil objetivo (Tradutores 10 e 12), significa apontar para a presença de algumas características conservadoras, como por exemplo, o uso de notas do tradutor.

Em termos de segurança jurídica da tradução, os tradutores apresentaram posturas condizentes com a fé pública que lhes foi delegada, à exceção dos Tradutores 4 e 12. O Tradutor 4 demonstrou uma tendência extremamente objetiva e sucinta, que poderia vir a abalar, de certo modo, a confiabilidade do conteúdo integral das informações, além da falta de elementos que caracterizam um documento oficial, como por exemplo, o selo do tradutor, o Brasão da República. Todavia, suas omissões consistiram em elementos secundários, o que provavelmente não viria a causar prejuízos ao propósito da tradução. O Tradutor 12 entregou a tradução com uma pequena falha na impressão, fato que prejudicou a leitura de duas notas. 
Esse problema seria solucionado mediante a solicitação pelo cliente de uma reimpressão da tradução.

Por fim, considerando a amostra dos tradutores como um todo, independentemente das tendências de perfil observadas, notamos que a visibilidade do tradutor público e intérprete comercial é notória, positiva e necessária, como garantia jurídica da boa aplicação da fé pública, no cumprimento de seu ofício.

\subsection{Contribuições para o modelo das modalidades}

Desde o seu desenvolvimento, o modelo descritivo das modalidades de tradução (Aubert, 1984, 1998, 2006), derivado do modelo pedagógico dos procedimentos técnicos da tradução de Vinay \& Darbelnet, publicado em 1958, tornou-se popular entre os pesquisadores brasileiros (cf. Aubert, 2006:46); a saber, dentre outros, Queirós (1978), que apresentou versão comentada do modelo em dissertação de mestrado; Fregonezi (1984), com a abordagem das múltiplas formas de transposição em tese de doutorado; e Barbosa (1990), que propôs uma revisão sistemática do modelo à luz do desenvolvimento da linguística textual na época (cf. Aubert, 1998).

No tocante a outras abordagens de pesquisa, as modalidades foram adotadas para a descrição de amostras de segmentos de texto contínuo (entre 500 e 800 palavras por texto selecionado), como em Alves (1983), que examinou um corpus de textos de Ciências Humanas (incluindo as áreas de psicologia, comunicação, sociologia, linguística, filosofia e economia); Darin (1986), que abordou um texto mais literário em estudo com critérios interpretativos similares à pesquisa de Alves; Silva (1992), em uma tentativa de revisão sistemática do modelo das modalidades, apresentou uma abordagem multilingual, com a análise de traduções para o inglês e castelhano de um conto de Rubem Fonseca; Zanotto (1993), que iniciou o enfoque na correlação entre tipologia textual e distribuição das modalidades; e Camargo (1993, 1996), com o objetivo principal de verificar se as modalidades de tradução contribuem na definição do idioleto do tradutor (cf. Aubert, 1998). Nesse início da linha de pesquisa, a ênfase da direção tradutória concentrou-se do inglês para o português. Em seguida, novos estudos foram realizados com enfoque nos marcadores 
linguísticos das especificidades culturais por Aubert (2006), Aubert e Zavaglia (2004a, 2004b, 2005), e Zavaglia (2004a, 2004b); apenas para citar alguns dos diversos trabalhos e pesquisas, sem mencionar os demais em andamento.

Desse modo, nossa escolha pela tipologia de documentos escolares e acadêmicos, bem como a direção tradutória do português para inglês, buscou colaborar com as pesquisas com base no modelo aubertiano e com a área da tradução juramentada. E, por conseguinte, surgiram novos tipos de classificação mais presentes em textos pragmáticos, observados nas classificações híbridas de transcrição numérica e tradução palavra por palavra dos respectivos sistemas numéricos ordinais, no caso de $7^{o}$ por $7^{\text {th }}$ e $1^{o}, 2^{o}$ e $3^{o}$ por $1^{s t}$, $2^{\text {nd }}$ e $3^{r d}$, respectivamente; e do sistema métrico, pela troca do ponto pela vírgula, como em 19.608 por 19,608, conforme o que se segue:

\begin{tabular}{l|l|l}
\hline $\begin{array}{c}\text { unidade lexical do } \\
\text { original }\end{array}$ & \multicolumn{1}{|c|}{$\begin{array}{c}\text { tradução } \\
\text { resgatada }\end{array}$} & \multicolumn{1}{c}{ modalidade de tradução } \\
\hline $2^{0}$ & $2^{\text {nd }}$ & $\begin{array}{l}{[1+4] \text { transcrição e tradução }} \\
\text { palavra por palavra }\end{array}$ \\
\hline 19.068 & 19,068 & $\begin{array}{l}{[1+4] \text { transcrição e tradução }} \\
\text { palavra por palavra }\end{array}$ \\
\hline \hline
\end{tabular}

Notamos que, em virtude das especificidades dos idiomas, o sistema métrico é "traduzido". Ademais, encontramos outras formas de tradução intersemiótica, além de carimbos notariais e brasões de armas, como nos exemplos abaixo:

\begin{tabular}{l|l|l}
\hline \hline $\begin{array}{c}\text { unidade lexical do } \\
\text { original }\end{array}$ & \multicolumn{1}{|c}{$\begin{array}{c}\text { tradução } \\
\text { resgatada }\end{array}$} & \multicolumn{1}{c}{ modalidade de tradução } \\
\hline$\S$ & $\S$ & {$[1]$ transcrição } \\
\hline$\S$ & paragraph & {$[11]$ tradução intersemiótica } \\
\hline 3 & three & {$[11]$ tradução intersemiótica } \\
\hline $22 / 04 / 99$ & $04 / 22 / 99$ & {$[5]$ transposição } \\
\hline $22 / 04 / 99$ & April, 22nd, 1999 & {$[11]$ tradução intersemiótica } \\
\hline \hline
\end{tabular}

Como podemos perceber, o símbolo $\S$ ora foi traduzido por paragraph ou mantido como $\S$, assim como 3 por 3 ou three, e algumas datas em formato numérico foram transcritas por alguns tradutores ou redigidas por extenso. Uma vez que até o presente momento questões como essas ainda não tinham sido classificadas, à luz do modelo das modalidades de tradução, consideramos útil destacá-las a título de colaboração para a ferramenta. 


\section{CONSIDERAÇÕES FINAIS}

De acordo com os resultados anteriores, pôde-se, por meio da aplicação da proposta de reformulação das modalidades de Aubert (2006), quantificar o grau de visibilidade ou mediação exercido pelos tradutores na transferência da mensagem da língua de partida para a língua de chegada, em um contexto de tradução juramentada. A aplicação do modelo das modalidades de tradução permitiu o exame das onze modalidades tradutórias levantadas, num total de sete mil duzentos e sessenta itens lexicais. Nessa amostra, a transcrição apresentou incidência elevada, bem como os empréstimos, o que aparentemente podem vir a ser marcadores da tipologia de textos escolares e acadêmicos.

Por sua vez, a maior incidência da modalidade de tradução palavra por palavra, em ambos os grupos, revela uma propensão a uma atuação mais cautelosa da parte do tradutor público diante de sua condição. Na própria tabela de emolumentos da Junta Comercial do Estado de São Paulo, há o item 5 referente à definição do valor para o laudo de exame e conferência de exatidão de tradução ou versão de outro tradutor público. ${ }^{45} \mathrm{Ou}$ seja, na eventualidade de qualquer contestação ou questionamento da tradução por parte de um usuário ou cliente, é solicitada a realização de um laudo por outro tradutor público.

Entre os tradutores profissionais não juramentados, a tendência à literalidade também se mostra presente, conforme Camargo (2004) comenta em um trabalho sobre a análise de semelhanças e diferenças na tradução de textos técnicos, jornalísticos e literários:

Se de um lado o menor uso da tradução literal nos três corpora reporta-se ao de textos literários, de outro lado é a categoria que se destaca, nas amostras desse tipo de texto, como a mais utilizada pelos tradutores profissionais. Com relação ao maior uso da tradução literal nos corpora encontrar-se em textos jornalísticos, poderia atribuir-se que essa maior propensão para a literalidade seria decorrente das pressões de urgência no prazo sobre os tradutores de jornais e revistas para entregarem a matéria traduzida o mais rápido possível, o que não lhes permitiria o tempo suficiente para maiores reelaborações semânticas e estilísticas. Os resultados estariam também indicando que, para esse tipo de texto, os tradutores buscariam opções na LC que são bastante similares às formas da LP. (Camargo, 2004:18)

\footnotetext{
${ }^{45}$ Disponível em: http://www.institucional.jucesp.sp.gov.br/downloads/deliberação_jucesp_3_2014.pdf
} 
Essas pressões de urgência e prazo que, em parte, motivam a tendência à literalidade pelos tradutores profissionais, mostram-se acentuadas pela pressão da fé pública no caso do tradutor juramentado. Esse componente a mais parece simular que a cada linha sua competência é avaliada quanto ao exercício das funções inerentes ao cargo.

Diante do resultado da comparação entre as gerações, o grupo mais antigo de 1978 demonstrou a tendência a um perfil mais conservador e detalhista, enquanto que, o grupo mais recente, a tendência observada foi de um perfil mais objetivo; resultado esse que não é de se surpreender, ao considerarmos as características inerentes aos dois grupos. Duas gerações com 20 anos de diferença em suas formações acadêmicas, experiência profissional e atuação na praxe juramentada, sem mencionar todo o aparato tecnológico que foi desenvolvido nesse espaço de tempo.

Se de um lado o grupo mais antigo apresenta uma formação mais erudita, ou seja, de cultura vasta em determinados assuntos, de outro, o grupo recente tende a ser mais pragmático. Por pragmático, entende-se com formação em uma sociedade de informação, em que são treinados para produzir resultados, com maior objetividade, rapidez, em virtude das informações disponíveis. Trata-se de uma geração movida mais pelo know-where, ou seja, que tenha a habilidade de buscar e localizar a informação disponível em uma malha quase infinita de dados na internet. Em compensação, o grupo de 1978 representa uma geração com maior conhecimento cultural, caracterizada pela busca de como surgiram as coisas, portanto com tendências mais explicativas, devido à formação e experiência acadêmica diferenciadas.

Seria oportuno observar que esta pesquisa mostrou diversidade nas formas de intervenção do tradutor público com relação às notas do tradutor, ao uso de colchetes, parênteses e aparência geral da tradução. Além disso, houve grande dispersão de soluções encontrada, curiosamente, em itens considerados simples ou para os quais não se esperaria tal diversidade; fato que poderia ser atenuado por meio da elaboração de um guia similar ao adotado pela Junta Comercial do Estado de Minas Gerais, na forma do Anexo I da Resolução $\mathrm{RP} / 07 / 2012$.

Não se sugere aqui uma padronização, porém, uma orientação na tentativa de sanar dúvidas em situações mais simples. O exemplo da Junta Comercial de Minas Gerais poderia ser adotado em outros estados, a fim de colaborar para que haja uma melhor caracterização da 
tradução oficial, que essa possa ser rapidamente reconhecida pelos seus usuários, garantindo ainda mais sua segurança jurídica, tanto para o tradutor quanto para o usuário final.

Aubert (2012:5, grifo nosso) também comenta sobre a questão da padronização:

Embora o ciclo de vida - ou o fôlego - da coluna Dúvidas e Controvérsias
tenha se completado, a questão subjacente - a busca de uma normatização
da tarefa do tradutor público permanece uma meta a ser perseguida, em
seus aspectos terminológicos, tradutórios, textuais e, possivelmente,
jurídicos.

A tradução em si demanda excessiva dedicação, pesquisa, principalmente ao considerarmos que no processo tradutório estejam convergindo, “de maneira geralmente indissociável, questões linguísticas, antropológicas, culturais, sociais, psicológicas, ideológicas, etc" (Camargo, 2004:18). Nesse sentido, a existência de um conjunto de instruções para orientar a forma de apresentação e determinados procedimentos interligados à tradução, porém em seu aspecto formal, contribuiriam para o exercício das funções desses tradutores. O Estado de São Paulo destaca-se como o centro de negócios do Brasil, e a demanda por traduções requer cada vez mais agilidade. Sendo assim, para atender a essa demanda, seria muito útil a existência de uma orientação por parte do órgão fiscalizador semelhante ao guia elaborado pela Junta Comercial do Estado de Minas Gerais.

Caberia ainda observar que, para o futuro, questões como a manutenção dos livros poderiam ser reformuladas ou atualizadas nas regulamentações. A armazenagem nas nuvens já é uma realidade e poderia vir a se tornar o modo pelo qual os tradutores preservariam as informações públicas de forma segura e ampla. A criação de um centro de armazenagem dos livros de registro de traduções, além de manter o acervo público, também ficaria disponível para futuras pesquisas acadêmicas.

Ainda há muito o que se pesquisar nessa área da tradução juramentada e, para estudos e pesquisas futuras, sugerimos a aplicação deste desenho de pesquisa e do modelo das modalidades de tradução em corpora formados por traduções juramentadas de textos jurídicos, contratuais, técnicos, com vistas a explorar ainda mais a visibilidade e/ou liberdade do tradutor. Essas tipologias textuais permitiriam o estudo mais aprofundado das modalidades de transposição e modulação, conforme observa Aubert (2006): 
As modulações, tanto quanto as transposições, podem ser obrigatórias ou opcionais. Uma hipótese ainda a ser adequadamente investigada sugere que as transposições e as modulações optativas representam parcela significativa da manifestação, no plano linguístico, da liberdade do tradutor. (Aubert, 2006:52, grifos do autor)

Além dessa proposta de Aubert (2006), poderiam ser elaborados corpora constituídos por traduções de tradutores públicos lotados em diversos estados, para a observação de eventuais diferenças entre as deliberações das respectivas juntas comerciais; ou mesclar a observação da frequência e da distribuição das ocorrências das modalidades tradutórias entre amostras de tradutores públicos e não públicos, com o objetivo de comparar a influência da fé pública.

Por conseguinte, esperamos mediante a presente pesquisa ter oferecido uma pequena contribuição para maior interação entre mercado e academia, pela aplicação de teorias e modelos em textos reais. 


\section{REFERÊNCIAS}

ALVES, W. R. Tradução juramentada e marcadores culturais: uma questão de dizibilidade. 2005. Dissertação (Mestrado em Linguística) - Faculdade de Filosofia, Letras e Ciências Humanas, Universidade de São Paulo, São Paulo, 2005.

AUBERT, F. H. Em busca das refrações na literatura brasileira traduzida: revendo a ferramenta de análise. Literatura e Sociedade (USP), v. 9, 2006, p.60-69.

. Dilemas da literalidade na tradução juramentada. Trabalhos em linguística aplicada. Campinas, $\mathrm{n}^{\mathrm{o}} 44$ (2), Unicamp, 2005, p.173-294.

. (2012) Dúvidas e controvérsias. In Cadernos de Terminologia - Tradução juramentada no. 05. São Paulo: CITRAT/FFLCH, p. 5 - 43.

. (1998) Tipologia e procedimentos da tradução juramentada. Vol. 1: Teoria, legislação, modelos e exercícios práticos. São Paulo: CITRAT/FFLCH.

. (1998) Modalidades de Tradução: teoria e resultados. In TradTerm 5.1. São Paulo: CITRAT/FFLCH/USP.

. V Encontro Nacional de Tradutores. Tipologia da tradução: o caso da tradução juramentada. Anais. São Paulo: FFLCH/Humanitas, 1996(a), p. 105-118.

. A tradução literal: impossibilidade, inadequação ou meta? Ilha do

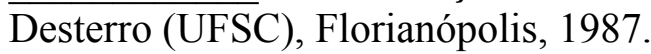

. Descrição e quantificação de dados em tradutologia. Tradução e Comunicação, São Paulo, n.4, 1984, p.71-82.

AZENHA Jr., João. Tradução técnica e condicionantes culturais: primeiros passos para um estudo integrado. São Paulo: Humanitas/FFLCH/USP, 1999.

BAKER, M. Corpus-based translation studies: the challenges that lie ahead. In: SOMERS, H. (Ed.). Terminology, LSP and Translation Studies in Language Engineering. Amsterdam/Philadelphia: John Benjamins, 1996, p. 175-186.

. Corpora in translation studies: an overview and some suggestions for future research. Target 7, 1995, 223-43.

. Corpus linguistics and translation studies: implications and applications. In: BAKER, M.; FRANCIS, G.; TOGNINI-BONELLI, E. (Eds). Text and technology: in honour of John Sinclair. Amsterdam/Philadelphia: John Benjamins, 1993, p. 233-250.

BARROS, L. A. Curso básico de Terminologia. São Paulo: EDUSP, 2004.

BERBER SARDINHA, Tony. Lingüística de Corpus. Barueri, SP: Editora Manole, 2004. 
$323-367$.

. Lingüística de corpus: histórico e problemática. D.E.L.T.A. 16 (2), 2000, p.

BERMAN, A. A tradução e a letra ou o albergue do longínquo. [tradutores Marie-Hélène Catherine Torres, Mauri Furlan, Andreia Guerini]. Rio de Janeiro: 7Letras/PGET, 2007.

BRANDELLI, Leonardo. Teoria geral do direito notarial. Porto Alegre: Livraria do Advogado, 1998.

BRASIL. DECRETO № 13.609 - 21 de outubro de 1943. Disponível em: http://www.dnrc.gov.br/Legislacao/decreto/dec13609.htm. Acesso em: 24/11/2012.

CAMARGO, D.C. XXIII ENANPOLL. Pesquisas em tradução e linguística de corpus. Anais -- GT de Tradução. Goiânia: ENANPOLL -- GT de Tradução / UFG, 2008. v. 1. p. 1-1.

. Padrões distributivos das modalidades de tradução inglês $\rightarrow$ português. 1996. Tése (Pós-doutorado em linguística) - Faculdade de Filosofia, Letras e Ciências Humanas, Universidade de São Paulo, São Paulo, 1996.

- Uma análise de semelhanças e diferenças na tradução de textos técnicos, jornalísticos e literários. In: DELTA vol.20 no.1 São Paulo Jan./Jun 2004. Disponível em: http://dx.doi.org/10.1590/S0102-44502004000100001. Acesso em: 14/05/15.

CAMPBELL, A. de S. Tradutores Públicos e traduções juramentadas no Brasil. In: PORTINHO, W.M. et al. A tradução técnica e seus problemas. São Paulo: Editora Álamo, 1983. p. $107-146$.

CHESTERMAN, Andrew. Readings in Translation Theory. Helsinki: Oy Finn Lectura Ab, 1989.

DELVIZIO, I. A.; BARROS, L. A.; AUBERT, F. H. Modalidades tradutórias aplicadas à tradução juramentada de documentos acadêmicos. In: Lídia Almeida Barros; Aparecida Negri Isquerdo. (Org.). O Léxico em foco: múltiplos olhares. 1ed. São Paulo: Cultura Acadêmica, 2010 , v. I.

DOWNES, J e GOODMAN J.E. Dicionário de Termos de Investimento e Financeiros. Tradução Ana Rocha Tradutores Associados. São Paulo: Nobel, 1993.

ERESP (Escritório de Representação em São Paulo do Ministério das Relações Exteriores). Disponível em: http://eresp.itamaraty.gov.br/pt-br/legalizacao_de_documentos.xml. Acesso em $25 / 02 / 2015$.

GARNER, B.A. Black's Law Dictionary. USA: West, a Thompson Business, 2004.

GOYOS JÚNIOR, Durval de Noronha. Noronha's Legal Dictionary = Noronha Dicionário Jurídico. English - Portuguese/ Português - Inglês, 2nd ed. São Paulo: Observador Legal Editora Ltda., 1994. 
ISOLAN, Rodrigo Werlang. A importância do reconhecimento de firma nos documentos particulares. 2009:1. Disponível em: http://espaco-vital.jusbrasil.com.br/noticias/111514/aimportancia-do-reconhecimento-de-firma-nos-documentos-particulares. Acesso em: 16/02/15.

LIMA, Lucas Almeida de Lopes. A Atividade Notarial e Registral e sua Natureza Jurídica. In: Âmbito Jurídico, Rio Grande, XIV, n. 92, set 2011. Disponível em: <http://www.ambitojuridico.com.br/site/index.php?n_link=revista_artigos_leitura\&artigo_id=10253 > Acesso em: 17/03/15.

MAGAlHÃES, C. M. Pesquisas textuais/discursivas em tradução: o uso de corpora. In: PAGANO, A. (Org.). Metodologias de pesquisa em tradução. Belo Horizonte: FALEUFMG, 2001, p. 93-103.

MANUAL DOS CANDIDATOS - Concurso para Habilitação de Tradutores Públicos e Intérpretes Comerciais. Secretaria da Justiça e Defesa da Cidadania da Junta Comercial do Estado de São Paulo, 1998.

MELLO, Maria Chaves de. Dicionário Jurídico português - inglês / inglês - português Portuguese - English / English - Portuguese - Law Dictionary. $7^{\text {a }}$ edição, Rio de Janeiro: Elfos, Ed. 1998.

MINAS GERAIS (Estado). Anexo I da Resolução RP/07/2012 de 18 de outubro de 2012 da Junta Comercial do Estado de Minas Gerais. Disponível em: http://www.jucemg.mg.gov.br/arquivos/file/RP07-2012.pdf. Acesso em: 10/02/15.

MUNDAY, J. Introducing Translation Studies. Theories and Applications. London and New York: Routledge, 2008, p. 72-74.

NEVES, Maria Helena de Moura. Guia de Uso do Português: Confrontando Regras e Usos. São Paulo: Unesp, 2003.

NASCIMENTO, L. A. S. Investigating norms in the Brazilian official translation of semiotic items, culture-bound items, and translator's paratextual interventions. 2006. Tese (Doutorado em Letras/Inglês) - Universidade Federal de Santa Catarina, Florianópolis, 2006.

OLIVEIRA, Luiz Eduardo Meneses de. (2005). As origens da profissão de tradutor público e intérprete comercial no Brasil (1808 - 1943). In: Claritas. São Paulo: Pontifícia Universidade Católica de São Paulo.

PINHO, Manoel Orlando de Morais. Dicionário de termos de negócios: português - inglês: English - Portuguese. São Paulo: Atlas, 1997.

RAPOSO, Mário. In Notariado, Lisboa: 1986, p. 689/690.

REIß, Katharina. Text Types, Translation Types and Translation Assessment. In: Chesterman, Andrew (ed.) (1989). Readings in Translation Theory. Helsinki: Oy Finn Lectura Ab, 1989.

Möglichkeiten und Grenzen der Übersetzungskritik: Kategorien und Kriteren für eine sachgerechte Beurteilung von Übersetzungen. Munich, Hueber, 1971. Translated into 
English by Erroll F. Rhodes as Translation Criticism: The Potentials and Limitations. Categories and Criteria for Translation Quality Assessment. St. Jerome Publishing Ltd, 2000.

. Texttyp und Übersetzungsmethode. Der operative Text. Kronberg/Ts, Scriptor Verlag, 1976.

REIß, Katharina e VERMEER, Hans J. Fundamentos para una teoria funcional de la traducción. Tubingen: Akal Ediciones. Tradução do alemão de: Sandra García Reina e Celia Martín de León, 1996.

REZENDE, Afonso Celso F. de. Tabelionato de Notas e o notário perfeito: direito de propriedade e atividade notarial. São Paulo: Copola, 1998.

SÃO PAUlO (Estado). DELIBERAÇÃO JUCESP № 04, de 01 de novembro de 2000. Disponível em: www.jucesp.fazenda.sp.gov.br/downloads/Deliberação_Jucesp_04_de_01.11.pdf. Acesso em 19/11/12.

SILVA, De Placido e. Vocabulário Jurídico / atualizadores: Nagib Slaibi Filho e Gláucia Carvalho - Rio de Janeiro: Forense, 2009.

VALIDÓRIO, V. C. Um estudo da tradução de termos culturalmente marcados em O Sumiço da Santa: The War of The Saints e Mar Morto: Sea of Death, de Jorge Amado, traduzidas por Gregory Rabassa. Estudos Linguísticos, Campinas, v.34, 2005, p.1.349-54.

VENUTI, Lawrence (Ed.). The translation studies reader. London: Routledge, 2004.

VINAY, Jean-Paul; DARBELNET, Jean. A Methodology for Translation. Translated by J. Sager and M.-J. Hamel. In: The translation studies reader. London: Routledge, 2004, p. 8493.

ZAVAGLIA, A. Marcas culturais no léxico especializado da tradução juramentada. In: ISQUERO, A. N.; CORNO, G. O. M. As ciências do léxico: lexicologia, lexicografia, terminologia. Campo Grande: Editora da Ufms, 2014. p. 39-48.

ZAVAGLIA, A. e POPPI, C. (2012). Cadernos de Terminologia - Tradução juramentada no. 05., São Paulo: CITRAT/FFLCH, p. $54-83$.

WYLER, Lia. Línguas, Poetas e Bacharéis: Uma Crônica da Tradução no Brasil. Rio de Janeiro: Rocco, 2003. 


\section{APÊNDICE - Levantamento e análise das versões dos doze tradutores}

\begin{tabular}{lll} 
& $\mathbf{1}-$ & Governo do Estado de São Paulo \\
\hline & Tradutor 1 & GOVERNMENT OF THE STATE OF SÃO PAULO [BRAZIL] \\
Grupo & Tradutor 2 & GOVERNMENT OF THE STATE OF SÃO PAULO \\
1978 & Tradutor 3 & GOVERNMENT OF THE STATE OF SÃO PAULO \\
& Tradutor 4 & GOVERNMENT OF THE STATE OF SÃO PAULO \\
& Tradutor 5 & THE GOVERNMENT OF THE STATE OF SÃO PAULO \\
& Tradutor 6 & GOVERNMENT OF THE STATE OF SÃO PAULO \\
\hline & Tradutor 7 & Government of the State of São Paulo \\
Grupo & Tradutor 8 & GOVERNMENT OF THE STATE OF SÃO PAULO \\
1998 & Tradutor 9 & Government of the State of São Paulo \\
& Tradutor 10 & GOVERNMENT OF THE STATE OF SÃO PAULO \\
& Tradutor 11 & STATE GOVERNMENT OF SÃO PAULO \\
& Tradutor 12 & GOVERNMENT OF THE STATE OF SÃO PAULO
\end{tabular}

Notas:

1-Uma ocorrência para Government of the State of São Paulo [Brazil]

2-Nove ocorrências para Government of the State of São Paulo

3-Uma ocorrência para The Government of the State of São Paulo

4-Uma ocorrência para State Government of São Paulo

\begin{tabular}{lll} 
& $\mathbf{2}$ - & Secretaria de Estado da Educação \\
\hline & Tradutor 1 & STATE BUREAU OF EDUCATION \\
Grupo & Tradutor 2 & STATE DEPARTMENT OF EDUCATION \\
1978 & Tradutor 3 & STATE SECRETARIAT OF EDUCATION \\
& Tradutor 4 & STATE EDUCATION DEPARTMENT \\
& Tradutor 5 & STATE DEPARTMENT OF EDUCATION \\
& Tradutor 6 & STATE DEPARTMENT OF EDUCATION \\
\hline \multirow{4}{*}{ Grupo } & Tradutor 7 & State Department of Education \\
1998 & Tradutor 8 & STATE SECRETARY OF EDUCATION \\
& Tradutor 9 & State Department of Education \\
& Tradutor 10 & STATE SECRETARY OF EDUCATION \\
& Tradutor 11 & STATE SECRETARY FOR EDUCATION \\
& Tradutor 12 & STATE SECRETARIAT OF EDUCATION
\end{tabular}

Notas:

1-Uma ocorrência para State Bureau of Education

2-Cinco ocorrências para State Department of Education

3-Duas ocorrências para State Secretariat of Education

4-Uma ocorrência para State Education Department

5-Duas ocorrências para State Secretary of Education

6-Uma ocorrência para State Secretary for Education

\section{3 - Coordenadoria de Ensino}

\begin{tabular}{lll}
\hline & Tradutor 1 & Coordinating Office of Education \\
Trupo & Tradutor 2 & Teaching Coordinator's Office \\
1978 & Tradutor 3 & Educational Affairs Coordination Office \\
& Tradutor 4 & EDitiu) \\
& Tradutor 5 & EDUCATION COORDINATING BOARD \\
& Tradutor 6 & TEACHING COORDINATION \\
\hline & Tradutor 7 & Education Coordination: COGSP [Education Coordination of the Greater São \\
& & Paulo] \\
Grupo & Tradutor 8 & TEACHING COORDINATION \\
1998 & Tradutor 9 & Teaching Coordination \\
& Tradutor 10 & EDUCATION COORDINATORS'S OFFICE \\
& Tradutor 11 & COORDINATION OF EDUCATION \\
& Tradutor 12 & Coordination of Education
\end{tabular}

Notas:

1-Uma ocorrência para Coordinating Office of Education

2-Uma ocorrência para Teaching Coordinator's Office

3-Uma ocorrência para Educational Affairs Coordination Office

4-Uma omissão

5-Uma ocorrência para Education Coordinating Board

6-Três ocorrências para Teaching Coordination 
7-Uma ocorrência para Education Coordination: COGSP [Education Coordination of the Greater São Paulo] 8-Uma ocorrência para Education Coordinators's Office (essa forma do genitivo nos parece inadequada) 9-Duas ocorrências para Coordination of Education

\begin{tabular}{lll} 
& $\mathbf{4}$ - & Da Região Metropolitana da Grande São Paulo \\
\hline \multirow{3}{*}{$\begin{array}{l}\text { Grupo } \\
1978\end{array}$} & Tradutor 1 & $\begin{array}{l}\text { for the Greater São Paulo Metropolitan Region } \\
\text { of the Metropolitan Region of the Greater São Paulo } \\
\text { of the Greater São Paulo Metropolitan Region } \\
\text { (omitiu) }\end{array}$ \\
& Tradutor 3 & GREATER SÃO PAULO METROPOLITAN AREA \\
& Tradutor 4 & OF THE METROPOLITAN REGION OF THE GREAT SÃO PAULO AREA \\
\hline \multirow{3}{*}{$\begin{array}{l}\text { Tradutor } 5 \\
\text { Tradutor } 6\end{array}$} & of the Greater São Paulo \\
& Tradutor 7 & OF THE METROPOLITAN REGION OF THE GREAT SÃO PAULO AREA \\
& Tradutor 8 & of the Metropolitan Region of Great São Paulo \\
& Tradutor 9 & OF THE METROPOLITAN REGION OF SÃO PAULO \\
& Tradutor 10 & FOR THE METROPOLITAN AREA OF GREAT SÃO PAULO
\end{tabular}

Notas: alto grau de dispersão

1-Uma ocorrência para for the Greater São Paulo Metropolitan Region

2-Uma ocorrência para of the Metropolitan Region of the Greater São Paulo

3-Uma ocorrência para of the Greater São Paulo Metropolitan Region

4-Uma omissão

5-Uma ocorrência para Greater São Paulo Metropolitan Area

6-Duas ocorrências para of the Metropolitan Region of the Great São Paulo Area

7-Uma ocorrência para of the Greater São Paulo

8-Uma ocorrência para of the Metropolitan Region of Great São Paulo

9-Uma ocorrência para of the Metropolitan Region of São Paulo

10-Uma ocorrência para for the Metropolitan Area of Great São Paulo

11-Uma ocorrência para of the Metropolitan Region of São Paulo

\begin{tabular}{|c|c|c|}
\hline \multirow{7}{*}{$\begin{array}{l}\text { Grupo } \\
1978\end{array}$} & Tradutor 1 & "Prof. Carlos Humberto Volpom" Regional Office of Education of São \\
\hline & & Caetano do Sul \\
\hline & Tradutor 2 & “Prof. Carlos Humberto Volpom” Teaching Office - (São Caetano do Sul) \\
\hline & Tradutor 3 & Professor Carlos Humberto Volpom Educational Affairs Commissioner's \\
\hline & Tradutor 4 & $\begin{array}{l}\text { Office (S.C.S. [City of São Caetano do Sul]) } \\
\text { (omitiu) }\end{array}$ \\
\hline & Tradutor 5 & "PROF. CARLOS HUMBERTO VOLPOM" SCHOOL DISTRICT - (S.C.S.) \\
\hline & Tradutor 6 & $\begin{array}{l}\text { DELEGACIA DE ENSINO "PROF. CARLOS HUMBERTO VOLPOM"- } \\
\text { (S.C.S.) [Prof. Carlos Humberto Volpom" Local Education Board] }\end{array}$ \\
\hline \multirow{6}{*}{$\begin{array}{l}\text { Grupo } \\
1998\end{array}$} & Tradutor 7 & $\begin{array}{l}\text { Teaching Department "PROF. CARLOS HUMBERTO VOLPOM"- (S.C.S.) } \\
\text { [São Caetano do Sul] }\end{array}$ \\
\hline & Tradutor 8 & TEACHING AGENCY “PROF. CARLOS HUMBERTO VOLPOM”- (S.C.S.) \\
\hline & Tradutor 9 & Teaching Department “Prof. Carlos Humberto Volpom”- (S.C.S.) \\
\hline & Tradutor 10 & $\begin{array}{l}\text { EDUCATION DEPARTMENT "PROF. CARLOS HUMBERTO VOLPOM" - } \\
\text { (S.C.S) }\end{array}$ \\
\hline & Tradutor 11 & SCHOOL DISTRICT “PROF. CARLOS HUMBERTO VOLPOM”- (S.C.S.) \\
\hline & Tradutor 12 & National School Board “Prof. Carlos Humberto Volpom”- (S.C.S.) \\
\hline
\end{tabular}

Nota: alto grau de dispersão. A tradução National School Board nos parece inadequada devido ao fato de a delegacia não ser em nível nacional.

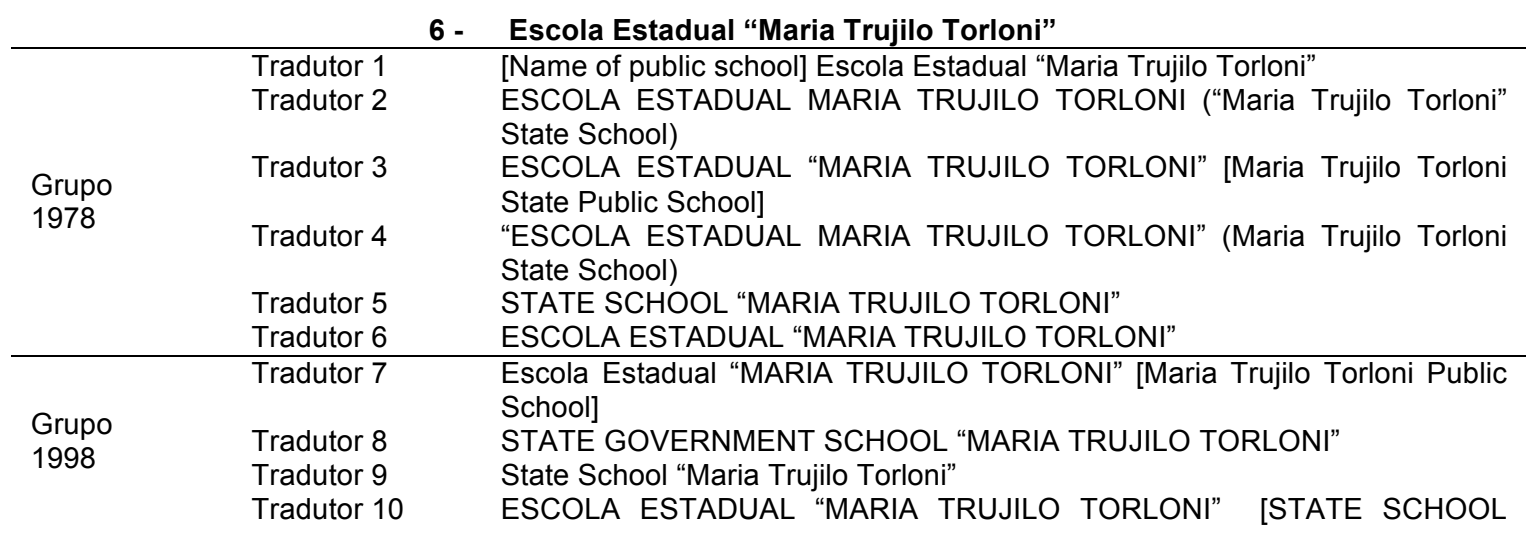




$\begin{array}{ll} & \text { "MARIA TRUJILO TORLONI" } \\ \text { Tradutor } 11 & \text { STATE SCHOLL "MARIA TRUJILO TORLONI" } \\ \text { Tradutor } 12 & \text { STATE SCHOOL "MARIA TRUJILO TORLONI }\end{array}$

Nota: alto grau de dispersão. Uma ocorrência de erro de grafia.

7 - Endereço: Estrada das Lágrimas, 579 - Bairro São José - Cep. 09581300 - São Caetano do Sul - São Paulo

\begin{tabular}{|c|c|c|}
\hline \multirow{6}{*}{$\begin{array}{l}\text { Grupo } \\
1978\end{array}$} & Tradutor 1 & $\begin{array}{l}\text { Address: Estrada das Lágrimas, } 579 \text { (Bairro São José) 09581-300 São } \\
\text { Caetano do Sul, State of São Paulo }\end{array}$ \\
\hline & Tradutor 2 & $\begin{array}{l}\text { Address: Estrada das Lágrimas, } 579 \text { - Bairro São José - CEP: 09581-300 - } \\
\text { São Caetano do Sul - São Paulo }\end{array}$ \\
\hline & Tradutor 3 & $\begin{array}{l}\text { Address: Estrada das Lágrimas, } 579 \text { - Bairro São José - CEP [zip] 09581- } \\
300 \text { - São Caetano do Sul, [State of] São Paulo }\end{array}$ \\
\hline & Tradutor 4 & $\begin{array}{l}\text { Address: Estrada das Lágrimas, } 579 \text { - Bairro São José - CEP 09581-300 - } \\
\text { São Caetano do Sul - São Paulo }\end{array}$ \\
\hline & Tradutor 5 & (ADDRESS) \\
\hline & Tradutor 6 & $\begin{array}{l}\text { Address: Estrada das Lágrimas, } 579 \text { - Bairro São José - CEP, 09581-300 - } \\
\text { São Caetano do Sul - São Paulo }\end{array}$ \\
\hline \multirow{6}{*}{$\begin{array}{l}\text { Grupo } \\
1998\end{array}$} & Tradutor 7 & $\begin{array}{l}\text { Address: Estrada das Lágrimas, } 579 \text { - Bairro São José - Zip Code: 09581- } \\
300 \text { - São Caetano do Sul - São Paulo }\end{array}$ \\
\hline & Tradutor 8 & $\begin{array}{l}\text { Address: Estrada das Lágrimas, } 579 \text { - District of São José - Zip Code } \\
\text { 09581-300 - São Caetano do Sul - São Paulo }\end{array}$ \\
\hline & Tradutor 9 & $\begin{array}{l}\text { Estrada das Lágrimas, } 579 \text { - Bairro São José - Postcode: 09581-300 - São } \\
\text { Caetano do Sul, São Paulo }\end{array}$ \\
\hline & Tradutor 10 & $\begin{array}{l}\text { ADDRESS: Estrada das Lagrimas, } 579 \text { - Bairro São Jose - CEP. 09581-300 } \\
\text { - São Caetano do Sul - São Paulo }\end{array}$ \\
\hline & Tradutor 11 & $\begin{array}{l}\text { ADDRESS: Estrada das Lágrimas, } 579 \text { - District São José - ZIP 09581-300 } \\
\text { - São Caetano do Sul - São Paulo }\end{array}$ \\
\hline & Tradutor 12 & $\begin{array}{l}\text { Address: Estrada das Lágrimas, } 579 \text { - District of São José - Postal Code: } \\
\text { 09581-300 - São Caetano do Sul - São Paulo }\end{array}$ \\
\hline
\end{tabular}

Nota: alto grau de dispersão.

\begin{tabular}{|c|c|c|}
\hline \multicolumn{2}{|r|}{8 - } & Ato de Criação da Escola: Lei no 7986, de 30/09/65 \\
\hline \multirow{6}{*}{$\begin{array}{l}\text { Grupo } \\
1978\end{array}$} & Tradutor 1 & Established by Law No. 7986 of 30 September 1965 \\
\hline & Tradutor 2 & School Created by Law No. 7986 dated September 30, 1965 \\
\hline & Tradutor 3 & School Incorporation Act: State-Law No. 7986 of 09/30/65 \\
\hline & Tradutor 4 & SCHOOL CREATED under Law N. 7986 as of 09/30/1965 \\
\hline & Tradutor 5 & ACT ESTABLISHING THE SCHOOL: Law no. 7986 , of 09/30/65 \\
\hline & Tradutor 6 & SCHOOL IMPLEMENTATION ACT - Law N N 7986 as of 09/30/65 \\
\hline \multirow{6}{*}{$\begin{array}{l}\text { Grupo } \\
1998\end{array}$} & Tradutor 7 & $\begin{array}{l}\text { School Establishment Act: Act No. } 7986 \text { - Brazilian Federal Register of } \\
09 / 30 / 65\end{array}$ \\
\hline & Tradutor 8 & School Creation Act: Law 7986 dated 30/Sep/65 \\
\hline & Tradutor 9 & Creation act: Law No. 7986, of Sep 30, 1965 \\
\hline & Tradutor 10 & School organized under: Law No. 7986, as of September 30, 1965 \\
\hline & Tradutor 11 & SCHOOL CREATING ACT: Law No. 7986, of 09/30/65 \\
\hline & Tradutor 12 & Act of Foundation of the School: Law no. 7986 , dated as of $30 / 09 / 65$ \\
\hline
\end{tabular}

Nota: alto grau de dispersão

\begin{tabular}{|c|c|c|}
\hline & & Histórico Escolar \\
\hline \multirow{6}{*}{$\begin{array}{l}\text { Grupo } \\
1978\end{array}$} & Tradutor 1 & TRANSCRIPT OF RECORDS \\
\hline & Tradutor 2 & SCHOOL RECORDS \\
\hline & Tradutor 3 & TRANSCRIPT \\
\hline & Tradutor 4 & FULL CURRICULUM \\
\hline & Tradutor 5 & TRANSCRIPT \\
\hline & Tradutor 6 & ACADEMIC RECORD TRANSCRIPT \\
\hline \multirow{6}{*}{$\begin{array}{l}\text { Grupo } \\
1998\end{array}$} & Tradutor 7 & School Transcript \\
\hline & Tradutor 8 & OFFICIAL TRANSCRIPT \\
\hline & Tradutor 9 & Transcript \\
\hline & Tradutor 10 & SCHOOL TRANSCRIPT \\
\hline & Tradutor 11 & SCHOOL RECORD \\
\hline & Tradutor 12 & ACADEMIC TRANSCRIPT \\
\hline
\end{tabular}

Notas:

1-Uma ocorrência para Transcript of Records

2-Uma ocorrência para School Records 
3-Três ocorrências para Transcript

4-Uma ocorrência para Full Curriculum

5-Uma ocorrência para Academic Record Transcript

6-Duas ocorrências para School Transcript

7-Uma ocorrência para Official Transcript

8-Uma ocorrência para School Record

9-Uma ocorrência para Academic Transcript

\begin{tabular}{|c|c|c|}
\hline \multicolumn{2}{|c|}{$10-2^{\circ} \mathrm{Grau}$} & \\
\hline \multirow{6}{*}{$\begin{array}{l}\text { Grupo } \\
1978\end{array}$} & Tradutor 1 & SECONDARY STUDIES [Senior High School] \\
\hline & Tradutor 2 & SECONDARY SCHOOL \\
\hline & Tradutor 3 & SENIOR HIGH SCHOOL \\
\hline & Tradutor 4 & SENIOR HIGH SCHOOL \\
\hline & Tradutor 5 & HIGH SCHOOL \\
\hline & Tradutor 6 & HIGH SCHOOL EDUCATION \\
\hline \multirow{6}{*}{$\begin{array}{l}\text { Grupo } \\
1998\end{array}$} & Tradutor 7 & High School \\
\hline & Tradutor 8 & SECONDARY SCHOOL \\
\hline & Tradutor 9 & High School \\
\hline & Tradutor 10 & SECONDARY EDUCATION \\
\hline & Tradutor 11 & SECONDARY SCHOOL \\
\hline & Tradutor 12 & HIGH SCHOOL \\
\hline
\end{tabular}

Notas:

1-Uma ocorrência para Secondary Studies [Senior High School]

2-Três ocorrências para Secondary School

3-Duas ocorrências para Senior High School

4-Quatro ocorrências para High School

5-Uma ocorrência para High School Education

6-Uma ocorrência para Secondary Education

\begin{tabular}{lll} 
& 11 - & Registro de Matrícula (RM) do Aluno \\
\hline & Tradutor 1 & Student enrollment number \\
Grupo & Tradutor 2 & Enrollment \\
1978 & Tradutor 3 & Student's Registration Number (RM) \\
& Tradutor 4 & STUDENT REGISTRATION NUMBER \\
& Tradutor 5 & STUDENT ENROLLMENT NUMBER (RM) \\
& Tradutor 6 & Student's School Registration (RM) \\
\hline \multirow{3}{*}{ Grupo } & Tradutor 7 & Student's Enrollment Registry (RM) \\
1998 & Tradutor 8 & Student's Enrollment number \\
& Tradutor 9 & Enrollment No. \\
& Tradutor 10 & STUDENT'S ENROLLMENT No. \\
& Tradutor 11 & ENROLLMENT RECORD (RM) OF THE STUDENT \\
& Tradutor 12 & Enrollment Registry (RM) of the Student
\end{tabular}

Nota: alto grau de dispersão

12 - Dados do Aluno

\begin{tabular}{lll} 
& & Dados do Aluno \\
\hline & Tradutor 1 & STUDENT \\
Grupo & Tradutor 2 & (omitiu) \\
1978 & Tradutor 3 & STUDENT DATA \\
& Tradutor 4 & STUDENT'S INFORMATION \\
& Tradutor 5 & STUDENT'S PERSONAL DATA \\
& Tradutor 6 & STUDENT's INFORMATION \\
\hline & Tradutor 7 & Student's Data \\
Grupo & Tradutor 8 & STUDENT'S DATA \\
1998 & Tradutor 9 & (omitiu) \\
& Tradutor 10 & Student's Personal Information \\
& Tradutor 11 & STUDENT DATA \\
& Tradutor 12 & STUDENT'S DATA
\end{tabular}

Notas:

1-Uma ocorrência para Student

2-Duas omissões

3-Duas ocorrências para Student Data

4-Duas ocorrências para Student's Information

5-Uma ocorrência para Student's Personal Data

6-Três ocorrências para Student's Data

7-Uma ocorrência para Student's Personal Information 
13 - Nome do Aluno

\begin{tabular}{lll} 
& 13 - & Nome do Aluno \\
\hline & Tradutor 1 & Name of Student \\
Grupo & Tradutor 2 & Student's Name \\
1978 & Tradutor 3 & Name of student \\
& Tradutor 4 & Name \\
& Tradutor 5 & Student Name \\
& Tradutor 6 & Student's Name \\
\hline \multirow{3}{*}{ Grupo } & Tradutor 7 & Student's Name \\
1998 & Tradutor 8 & Name of student \\
& Tradutor 9 & Name \\
& Tradutor 10 & Name \\
& Tradutor 11 & Name \\
& Tradutor 12 & Student's Name
\end{tabular}

Notas:

1-Três ocorrências para Name of Student

2-Quatro ocorrências para Student's Name

3-Quatro ocorrências para Name

4-Uma ocorrência para Student Name

\begin{tabular}{|c|c|c|}
\hline \multirow{7}{*}{$\begin{array}{l}\text { Grupo } \\
1978\end{array}$} & & \\
\hline & tirautor I & riace ol Dirtin \\
\hline & Tradutor 2 & Place of birth \\
\hline & Tradutor 3 & (omitiu) \\
\hline & Tradutor 4 & (omitiu) \\
\hline & Tradutor 5 & Born \\
\hline & Tradutor 6 & Birth \\
\hline \multirow{6}{*}{$\begin{array}{l}\text { Grupo } \\
1998\end{array}$} & Tradutor 7 & Place of Birth \\
\hline & Tradutor 8 & Birth \\
\hline & Tradutor 9 & Place of birth \\
\hline & Tradutor 10 & Birth information \\
\hline & Tradutor 11 & Birth \\
\hline & Tradutor 12 & Place of birth \\
\hline
\end{tabular}

Notas:

1-Cinco ocorrências para Place of birth. Tradutores uniram os itens 14 e 15.

2-Duas omissões

3-Uma ocorrência para Born

4-Três ocorrências para Birth

5-Uma ocorrência para Birth information

\begin{tabular}{lll} 
& 15 - & Localidade \\
\hline & Tradutor 1 & Place of birth \\
Grupo & Tradutor 2 & Place of birth \\
1978 & Tradutor 3 & Place and... \\
& Tradutor 4 & Place of birth \\
& Tradutor 5 & Place \\
& Tradutor 6 & Place \\
\hline \multicolumn{4}{c}{ Tradutor 7 } & Place of Birth \\
Grupo & Tradutor 8 & Place \\
1998 & Tradutor 9 & Place of birth \\
& Tradutor 10 & Location \\
\multicolumn{4}{c}{ Tradutor 11 } & Hometown \\
Notas: & Tradutor 12 & Place of birth \\
1-Seis ocorrências para Place of birth. Tradutores uniram os itens 14 e 15. \\
2-Uma ocorrência para Place and \\
3-Três ocorrências para Place \\
4-Uma ocorrência para Location \\
5-Uma ocorrência para Hometown
\end{tabular}


16 - Estado

\begin{tabular}{|c|c|c|}
\hline & Tradutor 1 & State \\
\hline & Tradutor 2 & State \\
\hline Grupo & Tradutor 3 & State \\
\hline 1978 & Tradutor 4 & State \\
\hline & Tradutor 5 & State \\
\hline & Tradutor 6 & State \\
\hline & Tradutor 7 & State \\
\hline & Tradutor 8 & State \\
\hline Grupo & Tradutor 9 & (omitiu) \\
\hline 1998 & Tradutor 10 & State \\
\hline & Tradutor 11 & State \\
\hline & Tradutor 12 & (omitiu) \\
\hline
\end{tabular}

Notas:

1-Dez ocorrências para State

2-Duas omissões

17 - Nacionalidade - Brasil.

\begin{tabular}{|c|c|c|}
\hline & Tradutor 1 & Nationality - Brazilian \\
\hline & Tradutor 2 & Nationality - Brazilian \\
\hline Grupo & Tradutor 3 & Nationality - Brazilian \\
\hline 1978 & Tradutor 4 & Nationality - Brazilian \\
\hline & Tradutor 5 & Nationality - Brazilian \\
\hline & Tradutor 6 & Nationality - Brazil \\
\hline & Tradutor 7 & Nationality - Brazil. \\
\hline & Tradutor 8 & Nationality - Brazilian \\
\hline Grupo & Tradutor 9 & Nationality - Brazilian \\
\hline 1998 & Tradutor 10 & Nationality - Brazilian \\
\hline & Tradutor 11 & Nationality - brazilian \\
\hline & Tradutor 12 & Citizenship - Brazilian \\
\hline
\end{tabular}

Notas:

1-Nove ocorrências para Nationality-Brazilian, uma em letra minúscula

2-Duas ocorrências para Nationality-Brazil

3-Uma ocorrência para Citizenship-Brazilian

\begin{tabular}{|c|c|c|}
\hline & Tradutor? & \\
\hline Grupo & & \\
\hline \multirow{6}{*}{1978} & & Date of birth - OCT/24/81 \\
\hline & Tradutor 4 & Date of birth - 10/24/1981 \\
\hline & Tradutor 5 & Day Month Year-24 1081 \\
\hline & Tradutor 6 & Month Day Year - 102481 \\
\hline & Tradutor 7 & Month Day Year - 102481 \\
\hline & Tradutor 8 & Day Month Year-24 1081 \\
\hline & Tradutor 9 & Date of birth - Oct 24, 1981 \\
\hline \multirow[t]{3}{*}{1998} & Tradutor 10 & Date of birth - 10/24/1981 \\
\hline & Tradutor 11 & Month Day Year - 102481 \\
\hline & Tradutor 12 & Date of birth $-24^{\text {th }}$ October 1981 \\
\hline
\end{tabular}

Nota: alto grau de dispersão

\begin{tabular}{|c|c|c|}
\hline & Tradutor 1 & Names of parents are no longer stated. \\
\hline & Tradutor 2 & The names of the parents are not mentioned herein \\
\hline Grupo & Tradutor 3 & Parents'names omitted \\
\hline \multirow[t]{5}{*}{1978} & Tradutor 4 & The student's parentage is omitted, \\
\hline & Tradutor 5 & Name of student's parents not included \\
\hline & Tradutor 6 & Student's parents' names not appearing on the record \\
\hline & Tradutor 7 & Parents' names were omitted, \\
\hline & Tradutor 8 & The names of the student's parents were not mentioned, \\
\hline Grupo & Tradutor 9 & The name of the parents were omitted \\
\hline \multirow[t]{3}{*}{1998} & Tradutor 10 & Parent's data omitted, \\
\hline & Tradutor 11 & ... the name of the student's parents are not mentioned. \\
\hline & Tradutor 12 & The parents' names no longer appear \\
\hline
\end{tabular}

Nota: alto grau de dispersão. Houve duas ocorrências com erro de concordância e uma com erro na forma genitiva. 
20 - conforme RES. SE-12,

\begin{tabular}{lll}
\hline Grupo & Tradutor 1 & $\begin{array}{l}\text { under Resolution SE-12, } \\
\text { as per Resolution No. 12 issued by the State Department of Education (SE) } \\
\text { as determined by SE [Secretariat of Education] RESOLUTION 12, } \\
\text { in accordance with Resolution SE-12, } \\
\text { pursuant to RES. SE-12, } \\
\text { Tradutor } 2\end{array}$ \\
$\begin{array}{lll}\text { Tradutor } 3 \\
\text { Tradutor } 4\end{array}$ & $\begin{array}{l}\text { in according to SE-12 Resolution, } \\
\text { Tradutor } 5\end{array}$ \\
& Tradutor 6 & Education] \\
Tradutor 7 & according to RES. SE-12, \\
according to Res. SE-12, & according to RES. SE-12, \\
1998 & Tradutor 8 & Pursuant to Resolution SE-12, \\
in accordance with Res. SE-12,
\end{tabular}

Notas: Alto grau de dispersão

1-Uma ocorrência para under Resolution SE-12

2-Uma ocorrência para as per Resolution No.12 issued by the State Department of Education (SE)

3-Uma ocorrência para as determined by SE [Secretariat of Education] Resolution 12

4-Uma ocorrência para in accordance with Resolution SE-12

5-Uma ocorrência para pursuant to RES.SE-12

6-Uma ocorrência para according to SE-12 Resolution

7-Três ocorrências para according to RES. SE-12

8-Uma ocorrência para pursuant to Resolution SE-12

9-Uma ocorrência para in accordance with Res. SE-12

21 - publicada em 13/06/95,

\begin{tabular}{|c|c|c|}
\hline \multirow{6}{*}{$\begin{array}{l}\text { Grupo } \\
1978\end{array}$} & Tradutor 1 & officially published on 13 June 1995 , \\
\hline & Tradutor 2 & published on June 13,1995 \\
\hline & Tradutor 3 & published on JUN/13/95, \\
\hline & Tradutor 4 & published on $06 / 13 / 1995$, \\
\hline & Tradutor 5 & published on $06 / 13 / 95$ \\
\hline & Tradutor 6 & published on June 13,1995 , \\
\hline \multirow{6}{*}{$\begin{array}{l}\text { Grupo } \\
1998\end{array}$} & Tradutor 7 & of $06 / 13 / 95$ \\
\hline & Tradutor 8 & published on 13/Jun/95, \\
\hline & Tradutor 9 & published on Jun 13,1995 \\
\hline & Tradutor 10 & published on June 13, 1995, \\
\hline & Tradutor 11 & published on $06 / 13 / 95$ \\
\hline & Tradutor 12 & published on $13 / 06 / 95$ \\
\hline
\end{tabular}

Notas:

1-Uma ocorrência para officially published on

2-Dez ocorrências para published on

3-Uma ocorrência para of 06/13/95

Notamos grande dispersão no formato das datas.

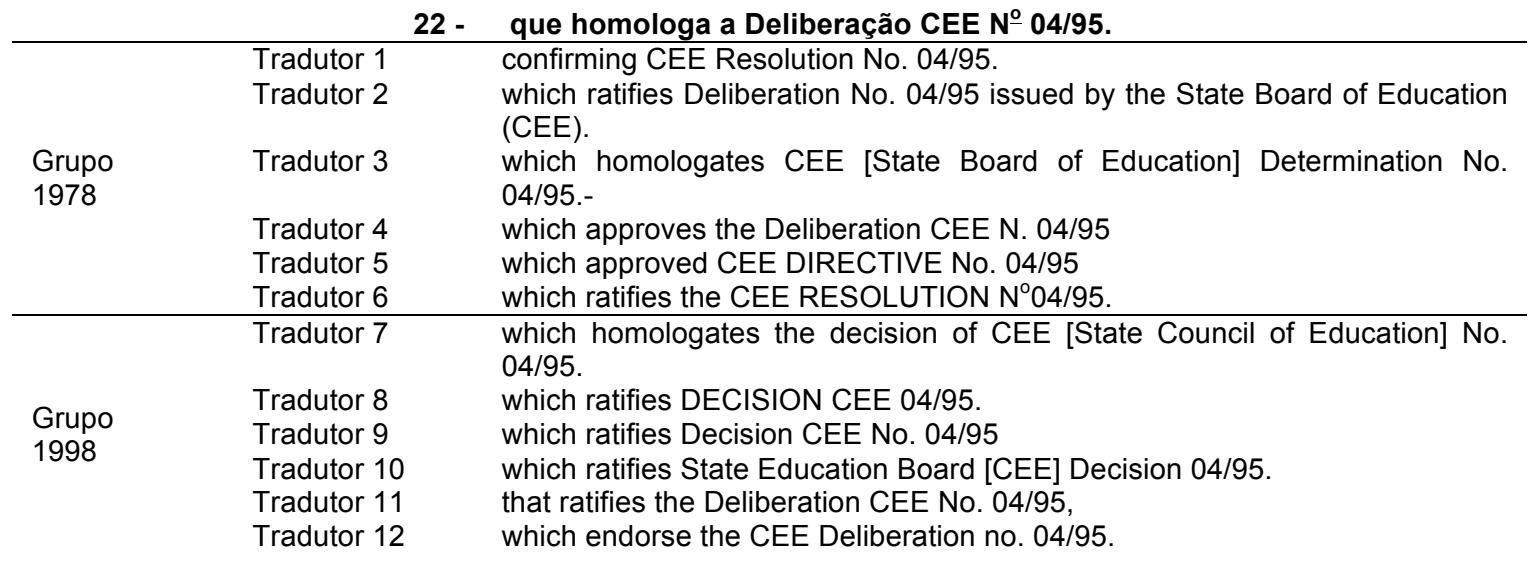

Nota: alto grau de dispersão 
23 - Resultados dos Estudos Realizados no $2^{\circ} \mathrm{Grau}$

\begin{tabular}{|c|c|c|}
\hline & Tradutor 1 & RESULTS OF SECONDARY [SENIOR HIGH SCHOOL] STUDIES \\
\hline & Tradutor 2 & RESULTS OBTAINED IN SECONDARY SCHOOL \\
\hline Grupo & Tradutor 3 & RESULTS OF STUDIES CARRIED OUT IN SENIOR HIGH SCHOOL \\
\hline \multirow[t]{5}{*}{1978} & Tradutor 4 & RESULTS OF STUDIES ACCOMPLISHED IN SENIOR HIGH SCHOOL \\
\hline & Tradutor 5 & HIGH SCHOOL ACHIEVEMENTS \\
\hline & Tradutor 6 & RESULTS OF COURSES TAKEN IN THE HIGH SCHOOL EDUCATION \\
\hline & Tradutor 7 & Results of the Studies Performed in High School \\
\hline & Tradutor 8 & RESULT OF THE STUDIES PERFORMED IN SECONDARY SCHOOL \\
\hline \multirow{4}{*}{$\begin{array}{l}\text { Grupo } \\
1998\end{array}$} & Tradutor 9 & Results of the studies taken in High School \\
\hline & Tradutor 10 & RESULTS ACHIEVED BY SUBJECT AT SECONDARY EDUCATION \\
\hline & Tradutor 11 & RESULTS OF THE STUDIES PERFORMED IN SECONDARY SCHOOL \\
\hline & Tradutor 12 & RESULTS OF STUDIES PERFORMED IN HIGH SCHOOL \\
\hline \multicolumn{3}{|c|}{ Notas: alto grau de dispersão } \\
\hline \multicolumn{2}{|r|}{24 - } & Curso \\
\hline \multirow{6}{*}{$\begin{array}{l}\text { Grupo } \\
1978\end{array}$} & Tradutor 1 & Program \\
\hline & Tradutor 2 & Course \\
\hline & Tradutor 3 & PROGRAM \\
\hline & Tradutor 4 & Course \\
\hline & Tradutor 5 & PROGRAM \\
\hline & Tradutor 6 & Course \\
\hline \multirow{6}{*}{$\begin{array}{l}\text { Grupo } \\
1998\end{array}$} & Tradutor 7 & Course \\
\hline & Tradutor 8 & PROGRAM \\
\hline & Tradutor 9 & (omitiu) \\
\hline & Tradutor 10 & COURSE \\
\hline & Tradutor 11 & COURSE \\
\hline & Tradutor 12 & Course \\
\hline
\end{tabular}

Notas:

1-Quatro ocorrências para Program

2-Sete ocorrências para Course

3-Uma omissão

25 - Inciso III

\begin{tabular}{|c|c|c|}
\hline & Tradutor 1 & (iii) \\
\hline & Tradutor 2 & Item III \\
\hline Grupo & Tradutor 3 & (iii) \\
\hline \multirow[t]{5}{*}{1978} & Tradutor 4 & in accordance with paragraph III \\
\hline & Tradutor 5 & Item III \\
\hline & Tradutor 6 & Subparagraph III \\
\hline & Tradutor 7 & Section III \\
\hline & Tradutor 8 & Subsection III \\
\hline Grupo & Tradutor 9 & Item III. \\
\hline \multirow[t]{3}{*}{1998} & Tradutor 10 & Item III \\
\hline & Tradutor 11 & Item III \\
\hline & Tradutor 12 & Item III \\
\hline
\end{tabular}

Notas:

1-Duas ocorrências para (iii)

2-Seis ocorrências para Item III

3-Uma ocorrência para in accordance with paragraph III

4-Uma ocorrência para Subparagraph III

5-Uma ocorrência para Section III

6-Uma ocorrência para Subsection III

\begin{tabular}{lll} 
& 26- & do art. $\mathbf{7}^{\circ}$ \\
\hline & Tradutor 1 & Under Article 7 \\
Grupo & Tradutor 2 & of Article 7 \\
1978 & Tradutor 3 & Article 7 \\
& Tradutor 4 & of article 7 \\
& Tradutor 5 & of section 7 \\
& of Article $7^{\text {th }}$ \\
\hline \multirow{3}{*}{ Tradutor 6} & Tradutor 7 & of article 7 \\
1998 & Tradutor 8 & of Section $7^{\text {th }}$ \\
& Tradutor 9 & art. 7 \\
& Tradutor 10 & article 7
\end{tabular}


Tradutor $11 \quad$ of Article 7

Tradutor $12 \quad$ of art. 7

Notas:

1-Uma ocorrência para under article 7

2-Quatro ocorrências para of article 7

3-Duas ocorrências para article 7

4-Uma ocorrência para of section 7

5-Uma ocorrência para of article 7th

6 -Uma ocorrência para of section $7 \mathrm{~h}$

7-Uma ocorrência para art. 7

8-Uma ocorrência para of art. 7

\begin{tabular}{lll} 
& 27 - & da Del. CEE 29/82 \\
\hline \multirow{4}{*}{ Grupo } & Tradutor 1 & of State Board of Education resolution CEE No. 29/82 \\
of Deliberation No. 29/82 issued by the State Board of Education (CEE)
\end{tabular}

Notas: alto grau de dispersão

28 - Ato de Autorização

\begin{tabular}{|c|c|c|}
\hline & Tradutor 1 & Authorization \\
\hline & Tradutor 2 & Authorization Act \\
\hline \multirow{6}{*}{$\begin{array}{l}\text { Grupo } \\
1978\end{array}$} & Tradutor 3 & Authorization Act \\
\hline & Tradutor 4 & Authorization Act \\
\hline & Tradutor 5 & AUTHORIZED BY \\
\hline & Tradutor 6 & Authorization Act \\
\hline & Tradutor 7 & Authorization Act \\
\hline & Tradutor 8 & AUTHORIZATION ACT \\
\hline \multirow{4}{*}{$\begin{array}{l}\text { Grupo } \\
1998\end{array}$} & Tradutor 9 & Authorization act \\
\hline & Tradutor 10 & Authorizing act \\
\hline & Tradutor 11 & AUTHORIZATION ACT \\
\hline & Tradutor 12 & Authorization act \\
\hline
\end{tabular}

Notas: baixo grau de dispersão

1-Uma ocorrência para Authorization

2-Nove ocorrências para Authorization Act

3-Uma ocorrência para Authorized by

4-Uma ocorrência para Authorizing Act

\section{9 - Res. SE 345-DOE 10/12/84}

Tradutor 1

Tradutor 2

Grupo

1978

Tradutor 3

Tradutor 4

Tradutor 5

Tradutor 6

Tradutor 7

Tradutor 8

Grupo

1998

Tradutor 8

Education bureau resolution No. 345 - officially published on 10 December 1984.

Resolution No. 345 issued by the State Department of Education (SE), published in the State Official Gazette on December 10, 1984. SE Resolution No. 345, [published in the] DOE [State Official Gazette] on $\mathrm{DEC} / 10 / 84$

in accordance with Resolution 345-DDE (DOE) as of 12/10/84

Res. SE 345 - ST. OFF. GAZ. (DOE) of 12/10/84 SE Resolution 345-Official Gazette of the State 12/10/84

Resolution of SE [Education Department] 345 - DOE [State Official Gazette] of $12 / 10 / 84$

Res. SF 345 published on the DOE (Official Gazette of the State Government) on 10/Dec/84

Res. SE-345-DOE of Dec 10, 1984

Tradutor 9
Tradutor 10

Tradutor 11

Res. SE 345 - State Official Gazette as of December 10, 1984

Tradutor 12

Resolution SF 345 - Official Gazette 12/10/84

Res. SE 345-DOE 10/12/84 
Nota: alto grau de dispersão. Duas ocorrências de erro nas siglas.

\begin{tabular}{lll} 
& 30 - & Matérias \\
\hline & Tradutor 1 & MAIN SUBJECTS \\
Grupo & Tradutor 2 & Subjects \\
1978 & Tradutor 3 & SUBJECTS \\
& Tradutor 4 & SUBJECTS \\
& Tradutor 5 & COURSES \\
& Tradutor 6 & SUBJECTS \\
\hline \multirow{3}{*}{ Grupo } & Tradutor 7 & Disciplines \\
1998 & Tradutor 8 & COURSES \\
& Tradutor 9 & Subjects \\
& Tradutor 10 & Field of Study \\
& Tradutor 11 & SUBJECTS \\
& Tradutor 12 & Subjects
\end{tabular}

Notas:

1-Uma ocorrência para Main Subjects

2-Sete ocorrências para Subjects

3-Duas ocorrências para Courses

4-Uma ocorrência para Disciplines

5-Uma ocorrência para Field of Study

\begin{tabular}{lll} 
& 31 - & Componentes Curriculares \\
\hline & Tradutor 1 & Components \\
Grupo & Tradutor 2 & Curricular Components \\
1978 & Tradutor 3 & CURRICULAR COMPONENTS \\
& Tradutor 4 & (omitiu) \\
& Tradutor 5 & CURRICULUM COMPONENTS \\
& Tradutor 6 & CURRICULAR COMPONENTS \\
\hline \multirow{4}{*}{ Grupo } & Tradutor 7 & Curriculum Area \\
1998 & Tradutor 8 & SUBJECTS \\
& Tradutor 9 & (omitiu) \\
& Tradutor 10 & Subject \\
& Tradutor 11 & CURRICULUM COMPONENTS \\
& Tradutor 12 & Curriculum Components
\end{tabular}

Notas:

1-Uma ocorrência para Components

2-Três ocorrências para Curricular Components

3-Duas omissões

4-Três ocorrências para Curriculum Components

5-Uma ocorrência para Curriculum Area

6-Uma ocorrência para Subjects

7-Uma ocorrência para Subject

32 - Menções ou Notas

\begin{tabular}{|c|c|c|}
\hline & Tradutor 1 & MARK \\
\hline & Tradutor 2 & Grade or Letter Grade \\
\hline Grupo & Tradutor 3 & GRADES OR MARKS \\
\hline 1978 & Tradutor 4 & GRADES \\
\hline & Tradutor 5 & DESIGNATIONS OR GRADES \\
\hline & Tradutor 6 & MARKS OR GRADES \\
\hline & Tradutor 7 & Letter or Number Grade \\
\hline & Tradutor 8 & MENTIONS OR MARKS \\
\hline Grupo & Tradutor 9 & Concepts or Points \\
\hline 1998 & Tradutor 10 & Grade \\
\hline & Tradutor 11 & GRADES \\
\hline & Tradutor 12 & Grades or Marks \\
\hline
\end{tabular}

Notas:

1-Uma ocorrência para Mark

2-Uma ocorrência para Grade or Letter Grade

3-Duas ocorrências para Grades or Marks e uma para Marks or Grades

4-Duas ocorrências para Grades

5-Uma ocorrência para Designations or Grades

7-Uma ocorrência para Letter or Number Grade

8-Uma ocorrência para Mentions or Marks 
9-Uma ocorrência para Concepts or Points 10-Uma ocorrência para Grade

\begin{tabular}{lll} 
& 33 - & Carga Horária \\
\hline & Tradutor 1 & CLASS HOURS \\
Grupo & Tradutor 2 & Course Load \\
1978 & Tradutor 3 & HOUR LOAD \\
& Tradutor 4 & TOTAL OF HOURS \\
& Tradutor 5 & COURSE HOURS \\
& Tradutor 6 & HOURS \\
\hline \multirow{4}{*}{ Grupo } & Tradutor 7 & Class Hours \\
1998 & Tradutor 8 & HOURLY LOAD \\
& Tradutor 9 & Hour Load \\
& Tradutor 10 & Credit Hours \\
& Tradutor 11 & COURSE LOAD \\
& Tradutor 12 & Class Hours
\end{tabular}

Notas:

1-Três ocorrências para Class Hours

2-Duas ocorrências para Course Load

3-Duas ocorrências para Hour Load

4-Uma ocorrência para Total of Hours

5-Uma ocorrência para Course Hours

6-Uma ocorrência para Hours

7-Uma ocorrência para Hourly Load

8-Uma ocorrência para Credit Hours

34 - Parte Comum

\begin{tabular}{lll} 
& Tradutor 1 & COMMON-CORE PROGRAM \\
Grupo & Tradutor 2 & Common Part \\
1978 & Tradutor 3 & COMMON PART \\
& Tradutor 4 & (omitiu) \\
& Tradutor 5 & COMMON REQUIREMENTS \\
& Tradutor 6 & COMMON CORE \\
\hline & Tradutor 7 & Common Part \\
Grupo & Tradutor 8 & COMMON PART \\
1998 & Tradutor 9 & Common Core \\
& Tradutor 10 & Common Part \\
& Tradutor 11 & COMMON BASIS \\
& Tradutor 12 & Common Part
\end{tabular}

Notas:

1-Uma ocorrência para Common-Core Program

2-Seis ocorrências para Common Part

3-Uma omissão

4-Uma ocorrência para Common Requirements

5-Duas ocorrências para Common Core

6-Uma ocorrência para Common Basis

\begin{tabular}{lll} 
& 35 - & RES. CFE 06/86 \\
\hline & Tradutor 1 & Under Federal Board of Education resolution CFE No. 6/86 \\
Grupo & Tradutor 2 & Resolution No. 06/86 issued by the Federal Board of Education (CFE) \\
1978 & Tradutor 3 & C.F.E. [Federal Council of Education] RESOLUTION NO. 06/86 \\
& Tradutor 4 & (omitiu) \\
& Tradutor 5 & RES. CFE 06/86 \\
& Tradutor 6 & CFE RESOLUTION 06/86 \\
\hline & Tradutor 7 & Resolution Federal Council of Education 06/86 \\
Grupo & Tradutor 8 & RES. CFE 06/86 \\
1998 & Tradutor 9 & RES. CFE 06/86 \\
& Tradutor 10 & RES. CFE 06/86 \\
& Tradutor 11 & RES. CFE 06/86 \\
& Tradutor 12 & Res. CFE 06/86
\end{tabular}

Notas:

1-Uma ocorrência para under Federal Board of Education resolution CFE No. 6/86

2-Uma ocorrência para Resolution No. 06/86 issued by the Federal Board of Education (CFE)

3-Uma ocorrência para C.F.E. [Federal Council of Education] Resolution No. 06/86

4-Uma omissão 
5-Seis ocorrências para RES. CFE 06/86

6-Uma ocorrência para CFE Resolution 06/86

7-Uma ocorrência para Resolution Federal Council of Education 06/86

\begin{tabular}{lll} 
& 36 - & Núcleo Comum \\
\hline & Tradutor 1 & (omitiu) \\
Grupo & Tradutor 2 & Common Nucleus \\
1978 & Tradutor 3 & Core Curriculum \\
& Tradutor 4 & (omitiu) \\
& Tradutor 5 & Common Core \\
& Tradutor 6 & CORE CURRICULUM \\
\hline \multirow{3}{*}{ Grupo } & Tradutor 7 & Common Core \\
1998 & Tradutor 8 & COMMON NUCLEUS \\
& Tradutor 9 & (omitiu) \\
& Tradutor 10 & Common Classes \\
& Tradutor 11 & Comon Core \\
& Tradutor 12 & Common Core
\end{tabular}

Notas:

1-Três omissões

2-Duas ocorrências para Common Nucleus

3-Duas ocorrências para Core Curriculum

4-Quatro ocorrências para Common Core (uma com erro de grafia)

5-Uma ocorrência para Common Classes

\begin{tabular}{|c|c|c|}
\hline \multicolumn{3}{|c|}{37 - Português } \\
\hline \multirow{6}{*}{$\begin{array}{l}\text { Grupo } \\
1978\end{array}$} & Tradutor 1 & PORTUGUESE \\
\hline & Tradutor 2 & Portuguese \\
\hline & Tradutor 3 & PORTUGUESE \\
\hline & Tradutor 4 & (omitiu) \\
\hline & Tradutor 5 & PORTUGUESE \\
\hline & Tradutor 6 & Portuguese \\
\hline \multirow{6}{*}{$\begin{array}{l}\text { Grupo } \\
1998\end{array}$} & Tradutor 7 & Portuguese \\
\hline & Tradutor 8 & Portuguese \\
\hline & Tradutor 9 & Portuguese \\
\hline & Tradutor 10 & Portuguese \\
\hline & Tradutor 11 & PORTUUGUESE \\
\hline & Tradutor 12 & Portuguese \\
\hline
\end{tabular}

Notas:

1-Onze ocorrências para Portuguese

2-Uma omissão

38 - Língua Port. e Literatura

\begin{tabular}{lll}
\hline & Tradutor 1 & Portuguese Language and Literature \\
Grupo & Tradutor 2 & Portuguese Language and Literature \\
1978 & Tradutor 3 & Portuguese Language and Literature \\
& Tradutor 4 & Portuguese Language and Literature \\
& Tradutor 5 & PORT. LANGUAGE AND LITERATURE \\
& Tradutor 6 & Portuguese Language and Literature \\
\hline & Tradutor 7 & Portuguese and Literature \\
Grupo & Tradutor 8 & Portuguese Language and Literature \\
1998 & Tradutor 9 & Portuguese Language and Literature \\
& Tradutor 10 & Portuguese Language and Literature \\
& Tradutor 11 & PORTUGUESE LANG. AND LITERATURE \\
& Tradutor 12 & Portuguese Language and Literature
\end{tabular}

Notas:

1-Nove ocorrências para Portuguese Language and Literature

2-Uma ocorrência com forma abreviada para Port. Language and Literature

3-Uma ocorrência para Portuguese and Literature

4-Uma ocorrência com forma abreviada para Portuguese Lang. and Literature 


\begin{tabular}{|c|c|c|}
\hline & & $1^{\mathrm{a}} 2^{\mathrm{a}} 3^{\mathrm{a}}$ \\
\hline & Tradutor 1 & $1^{\text {st }} 2^{\text {nd }} 3^{\text {rd }}$ \\
\hline & Tradutor 2 & $1^{\text {st }} 2^{\text {nd }} 3^{\text {rd }}$ \\
\hline Grupo & Tradutor 3 & $1^{\text {st }}$ Grade $2^{\text {nd }}$ Grade $3^{\text {rd }}$ Grade \\
\hline 1978 & Tradutor 4 & $1^{\text {st }} 2^{\text {nd }} 3^{\text {rd }}$ \\
\hline & Tradutor 5 & $1^{\text {st }} 2^{\text {nd }} 3^{\text {rd }}$ \\
\hline & Tradutor 6 & 1st 2nd 3rd \\
\hline & Tradutor 7 & $1^{\text {st }} 2^{\text {nd }} 3^{\text {rd }}$ \\
\hline & Tradutor 8 & $1^{\text {st }} 2^{\text {nd }} 3^{\text {rd }}$ \\
\hline Grupo & Tradutor 9 & $1^{\text {st }} 2^{\text {nd }} 3^{\text {rd }}$ \\
\hline 1998 & Tradutor 10 & $1^{\text {st }} 2^{\text {nd }} 3^{\text {rd }}$ \\
\hline & Tradutor 11 & $1^{\text {st }} 2^{\text {nd }} 3^{\text {rd }}$ \\
\hline & Tradutor 12 & $1^{\text {st }} 2^{\text {nd }} 3^{\text {rd }}$ \\
\hline
\end{tabular}

Notas: baixo grau de dispersão

1-Onze ocorrências para $1^{\text {st }} 2^{\text {nd }} 3^{\text {rd }}$

2-Uma ocorrência para $1^{\text {st }}$ Grade $2^{\text {nd }}$ Grade $3^{\text {rd }}$ Grade

\begin{tabular}{lll} 
& $\mathbf{4 0}-$ & Total \\
\hline & Tradutor 1 & TOTAL \\
Grupo & Tradutor 2 & Total \\
1978 & Tradutor 3 & TOTAL \\
& Tradutor 4 & (omitiu) \\
& Tradutor 5 & TOTAL \\
& Tradutor 6 & Total \\
\hline \multirow{4}{*}{ Grupo } & Tradutor 7 & Total \\
1998 & Tradutor 8 & Total \\
& Tradutor 9 & Total \\
& Tradutor 10 & Total \\
& Tradutor 11 & TOTAL
\end{tabular}

Notas:

1-Onze ocorrências para Total

2-Uma omissão

\begin{tabular}{lll} 
& 41 - & Estudos Sociais \\
\hline & Tradutor 1 & SOCIAL STUDIES \\
Grupo & Tradutor 2 & Social Studies \\
1978 & Tradutor 3 & SOCIAL STUDIES \\
& Tradutor 4 & (omitiu) \\
& Tradutor 5 & SOCIAL STUDIES \\
& Tradutor 6 & Social Studies \\
\hline \multirow{3}{*}{ Grupo } & Tradutor 7 & Social Studies \\
1998 & Tradutor 8 & Social Studies \\
& Tradutor 9 & Social Studies \\
& Tradutor 10 & Social Studies \\
& Tradutor 11 & SOCIAL STUDIES
\end{tabular}

Notas:

1-Onze ocorrências para Social Studies

2-Uma omissão

\begin{tabular}{lll} 
& 42 - & História \\
\hline & Tradutor 1 & History \\
Grupo & Tradutor 2 & History \\
1978 & Tradutor 3 & History \\
& Tradutor 4 & History \\
& Tradutor 5 & History \\
& Tradutor 6 & History \\
\hline \multirow{4}{*}{ Grupo } & Tradutor 7 & History \\
1998 & Tradutor 8 & History \\
& Tradutor 9 & History \\
& Tradutor 10 & History \\
& Tradutor 11 & HISTORY \\
& Tradutor 12 & History
\end{tabular}

Nota: sem dispersão 
43 - Geografia

\begin{tabular}{lll}
\hline & Tradutor 1 & Geography \\
Grupo & Tradutor 2 & Geography \\
1978 & Tradutor 3 & Geography \\
& Tradutor 4 & Geography \\
& Tradutor 5 & Geography \\
& Tradutor 6 & Geography \\
\hline & Tradutor 7 & Geography \\
Grupo & Tradutor 8 & Geography \\
1998 & Tradutor 9 & Geography \\
& Tradutor 10 & Geography \\
& Tradutor 11 & GEOGRAPHY \\
& Tradutor 12 & Geography
\end{tabular}

Nota: sem dispersão

\begin{tabular}{lll} 
& 44 - & Ciências \\
\hline & Tradutor 1 & SCIENCE \\
Grupo & Tradutor 2 & Sciences \\
1978 & Tradutor 3 & SCIENCES \\
& Tradutor 4 & (omitiu) \\
& Tradutor 5 & SCIENCE \\
& Tradutor 6 & Sciences \\
\hline \multirow{4}{*}{ Grupo } & Tradutor 7 & Sciences \\
1998 & Tradutor 8 & Sciences \\
& Tradutor 9 & Sciences \\
& Tradutor 10 & Sciences \\
& Tradutor 11 & SCIENCES
\end{tabular}

Notas:

1-Duas ocorrências para Science

2-Nove ocorrências para Sciences

3-Uma omissão

\begin{tabular}{|c|c|c|}
\hline \multicolumn{3}{|c|}{45 - Física } \\
\hline \multirow{6}{*}{$\begin{array}{l}\text { Grupo } \\
1978\end{array}$} & Tradutor 1 & Physics \\
\hline & Tradutor 2 & Physics \\
\hline & Tradutor 3 & Physics \\
\hline & Tradutor 4 & Physics \\
\hline & Tradutor 5 & Physics \\
\hline & Tradutor 6 & Physics \\
\hline \multirow{6}{*}{$\begin{array}{l}\text { Grupo } \\
1998\end{array}$} & Tradutor 7 & Physics \\
\hline & Tradutor 8 & Physics \\
\hline & Tradutor 9 & Physics \\
\hline & Tradutor 10 & Physics \\
\hline & Tradutor 11 & PHYSICS \\
\hline & Tradutor 12 & Physics \\
\hline
\end{tabular}

Nota: sem dispersão

46 - Química

\begin{tabular}{lll} 
& Tradutor 1 & Chemistry \\
Grupo & Tradutor 2 & Chemistry \\
1978 & Tradutor 3 & Chemistry \\
& Tradutor 4 & Chemistry \\
& Tradutor 5 & Chemistry \\
& Tradutor 6 & Chemistry \\
\hline & Tradutor 7 & Chemistry \\
Grupo & Tradutor 8 & Chemistry \\
1998 & Tradutor 9 & Chemistry \\
& Tradutor 10 & Chemistry \\
& Tradutor 11 & CHEMISTRY \\
& Tradutor 12 & Chemistry
\end{tabular}

Nota: sem dispersão 
47 - Biologia e Prog. de Saúde

\begin{tabular}{lll}
\hline & Tradutor 1 & Biology and Health Program \\
Grupo & Tradutor 2 & Biology and Health Program \\
1978 & Tradutor 3 & Biology and Health Programs \\
& Tradutor 4 & Biology and Health Program \\
& Tradutor 5 & Biology and Health Topics \\
& Tradutor 6 & Biology and Health Program \\
\hline & Tradutor 7 & Biology and Health Program \\
Grupo & Tradutor 8 & Biology and Health Program \\
1998 & Tradutor 9 & Biology and Health Program \\
& Tradutor 10 & Biology and Health Sciences \\
& Tradutor 11 & BIOLOGY (omitiu) \\
& Tradutor 12 & Biology and Health Programs
\end{tabular}

Notas:

1-Sete ocorrências para Biology and Health Program

2-Duas ocorrências para Biology and Health Programs

3-Uma ocorrência para Biology and Health Topics

4-Uma ocorrência para Biology and Health Sciences

5-Uma ocorrência para Biology

\begin{tabular}{|c|c|c|}
\hline \multicolumn{3}{|c|}{48 - Matemática } \\
\hline & Tradutor 1 & MATHEMATICS \\
\hline & Tradutor 2 & Mathematics \\
\hline Grupo & Tradutor 3 & MATHEMATICS \\
\hline \multirow[t]{5}{*}{1978} & Tradutor 4 & Mathematics \\
\hline & Tradutor 5 & MATHEMATICS \\
\hline & Tradutor 6 & Mathematics \\
\hline & Tradutor 7 & Mathematics \\
\hline & Tradutor 8 & Mathematics \\
\hline Grupo & Tradutor 9 & Mathematics \\
\hline \multirow[t]{3}{*}{1998} & Tradutor 10 & Mathematics \\
\hline & Tradutor 11 & MATHEMATICS \\
\hline & Tradutor 12 & Mathematics \\
\hline
\end{tabular}

Nota: sem dispersão

49 - Língua Estrangeira Moderna (Inglês)

\begin{tabular}{|c|c|c|}
\hline \multirow{6}{*}{$\begin{array}{l}\text { Grupo } \\
1978\end{array}$} & Tradutor 1 & FOREIGN MODERN LANGUAGE English \\
\hline & Tradutor 2 & Modern Foreign Language (English) \\
\hline & Tradutor 3 & MODERN FOREIGN LANGUAGE English \\
\hline & Tradutor 4 & (omitiu) English \\
\hline & Tradutor 5 & MODERN FOREIGN LANGUAGE (English) \\
\hline & Tradutor 6 & Modern Foreign Language (English) \\
\hline \multirow{6}{*}{$\begin{array}{l}\text { Grupo } \\
1998\end{array}$} & Tradutor 7 & Modern Foreign Language (English) \\
\hline & Tradutor 8 & Modern foreign language (English) \\
\hline & Tradutor 9 & (omitiu) English \\
\hline & Tradutor 10 & Modern Foreign Language - English \\
\hline & Tradutor 11 & FOREIGN MODERN LANGUAGE (English) \\
\hline & Tradutor 12 & Modern Foreign Language English \\
\hline
\end{tabular}

Notas:

1-Duas ocorrências para Foreign Modern Language English

2-Oito ocorrências para Modern Foreign Language (English)

3-Duas ocorrências para English

50 - $\quad$ Art. $7^{\circ}$ da Lei $5692 / 71$

\begin{tabular}{lll}
\hline & Tradutor 1 & Under article 7 of Law 5692/71 \\
Grupo & Tradutor 2 & Article 7 of Law 5692/71 \\
1978 & Tradutor 3 & ARTICLE 7 OF STATUTE-LAW NO. 5,692/71 \\
& Tradutor 4 & (omitiu) \\
& Tradutor 5 & SEC. 7 OF LAW 5692/71 \\
& Tradutor 6 & Article $7^{\text {th }}$ of Law 5692/71 \\
\hline \multirow{2}{*}{ Grupo } & Tradutor 7 & Article 7 of the Act $5692 / 71$ \\
1998 & Tradutor 8 & Section $7^{\text {th }}$ of Law 5692/71 \\
& Tradutor 9 & Art. 7 of Law $5692 / 71$
\end{tabular}


Tradutor 10

Tradutor 11

Tradutor 12
Art. 7, Law 5692/71

ARTICLE 7 LAW 5692/71

Art. 7 of Law 5692/71

Notas: alto grau de dispersão

1-Uma ocorrência para under article 7 of Law 5692/71

2-Uma ocorrência para Article 7 of Law 5692/71

3-Uma ocorrência para Article 7 of Statute-Law No. 5692/71

4-Uma omissão

5-Uma ocorrência para Sec. 7 of Law 5692/71

6 -Uma ocorrência para Article $7^{\text {th }}$ of Law 5692/71

7-Uma ocorrência para Article 7 of the Act 5692/71

8-Uma ocorrência para Section $7^{\text {th }}$ of Law $5692 / 71$

9-Duas ocorrências para Art. 7 of Law 5692/71

10-Uma ocorrência para Art. 7, Law 5692/71

11-Uma ocorrência para Article 7 Law 5692/71

\begin{tabular}{lll} 
& $\mathbf{5 1}$ - & Educação Física \\
\hline & Tradutor 1 & Physical Education \\
Grupo & Tradutor 2 & Physical Education \\
1978 & Tradutor 3 & Physical Education \\
& Tradutor 4 & Physical Education \\
& Tradutor 5 & PHYSICAL EDUCATION \\
& Tradutor 6 & Physical Education \\
\hline \multirow{4}{*}{ Grupo } & Tradutor 7 & Physical Education \\
1998 & Tradutor 8 & Physical Education \\
& Tradutor 9 & Physical Education \\
& Tradutor 10 & Physical Education \\
& Tradutor 11 & PHYSICAL EDUCATION \\
& Tradutor 12 & Physical Education
\end{tabular}

Nota: sem dispersão

52 - Educação Artística

\begin{tabular}{lll}
\hline & Tradutor 1 & Art \\
Grupo & Tradutor 2 & Artistic Education \\
1978 & Tradutor 3 & Artistic Education \\
& Tradutor 4 & Art \\
& Tradutor 5 & ART EDUCATION \\
& Tradutor 6 & Artistic Education \\
\hline & Tradutor 7 & Arts \\
Grupo & Tradutor 8 & Artistic Education \\
1998 & Tradutor 9 & Arts \\
& Tradutor 10 & Arts \\
& Tradutor 11 & ARTISTIC EDUCATION \\
& Tradutor 12 & Arts
\end{tabular}

Notas:

1-Duas ocorrências para Art

2-Cinco ocorrências para Artistic Education

3-Uma ocorrência para Art Education

4-Quatro ocorrências para Arts

\begin{tabular}{lll} 
& $\mathbf{5 3}$ - & Educação Moral e Cívica \\
\hline & Tradutor 1 & Civics \\
Grupo & Tradutor 2 & (omitiu) \\
1978 & Tradutor 3 & (omitiu) \\
& Tradutor 4 & (omitiu) \\
& Tradutor 5 & MORAL AND CIVIC EDUCATION \\
& Tradutor 6 & Moral and Civic Education \\
\hline \multirow{4}{*}{ Grupo } & Tradutor 7 & Moral and Civic Education \\
1998 & Tradutor 8 & Moral and Civic Education \\
& Tradutor 9 & Moral and Civic Education \\
& Tradutor 10 & (omitiu) \\
& Tradutor 11 & MORAL AND CIVIC EDUCATION \\
& Tradutor 12 & Moral and Civic Education
\end{tabular}

Notas: 
1-Uma ocorrência para Civics

2-Quatro omissões

3-Sete ocorrências para Moral and Civic Education

\begin{tabular}{|c|c|c|}
\hline & & Parte Comum - total da carga horária \\
\hline \multirow{6}{*}{$\begin{array}{l}\text { Grupo } \\
1978\end{array}$} & Tradutor 1 & COMMON CORE - Total class hours \\
\hline & Tradutor 2 & COMMON PART - Total Course Load \\
\hline & Tradutor 3 & COMMON PART - total hour load \\
\hline & Tradutor 4 & (omitiu) \\
\hline & Tradutor 5 & COMMON REQUIREMENTS - total course hours \\
\hline & Tradutor 6 & CORE CURRICULUM - Total Number of Hours \\
\hline \multirow{6}{*}{$\begin{array}{l}\text { Grupo } \\
1998\end{array}$} & Tradutor 7 & Common Part - Total Class Hours \\
\hline & Tradutor 8 & COMMON PART - Full Hourly Load \\
\hline & Tradutor 9 & Total hour load of the common core \\
\hline & Tradutor 10 & Common Part - Total credit hours \\
\hline & Tradutor 11 & COMMON BASIS - total course load \\
\hline & Tradutor 12 & COMMON PART - total class hours \\
\hline
\end{tabular}

Nota: alto grau de dispersão

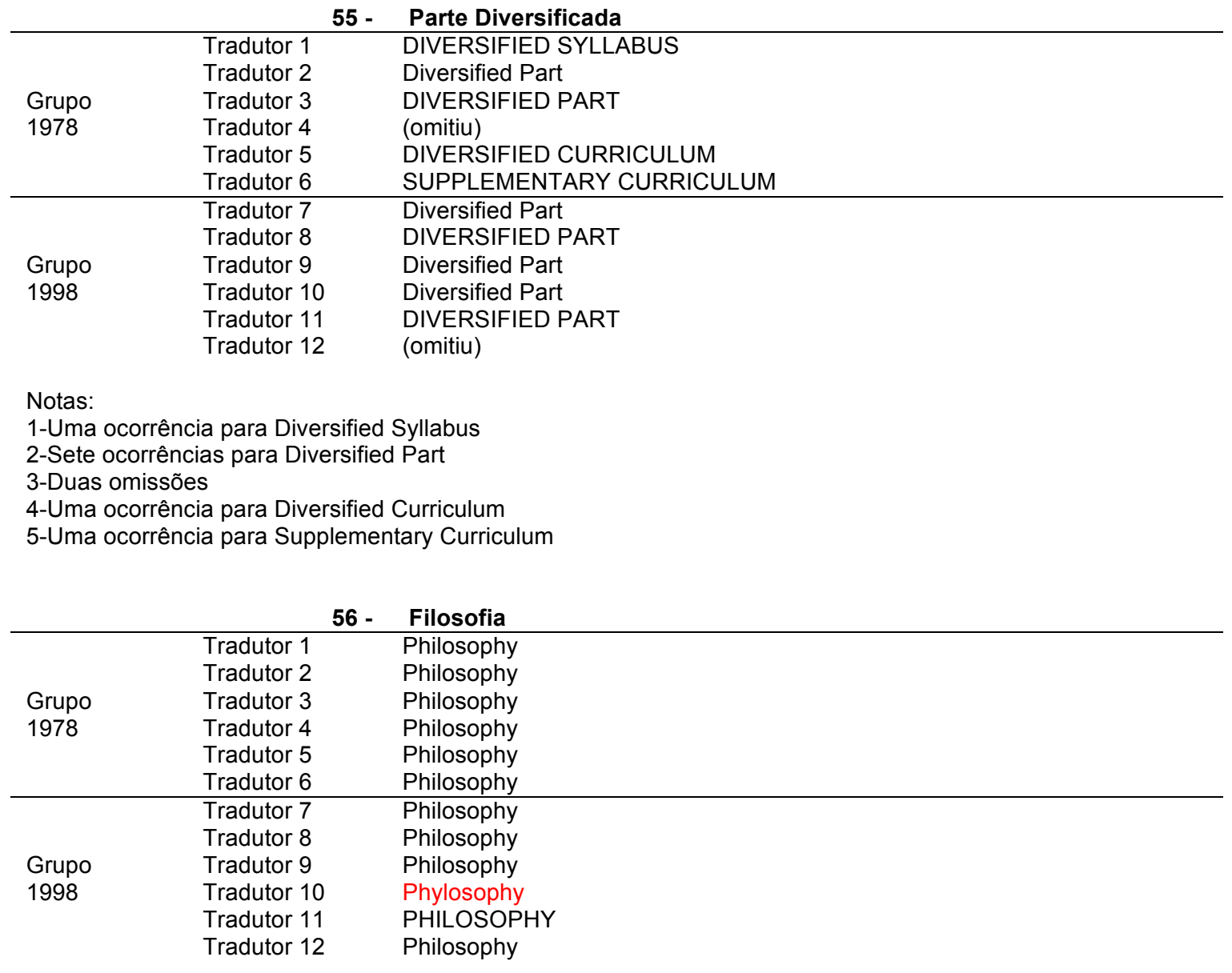

Nota: sem dispersão (com 1 erro de grafia)

\begin{tabular}{lll} 
& \multicolumn{5}{c}{$\mathbf{5 7}$ - } & Sociologia \\
\hline & Tradutor 1 & Sociology \\
Grupo & Tradutor 2 & Sociology \\
1978 & Tradutor 3 & Sociology \\
& Tradutor 4 & Sociology \\
& Tradutor 5 & Sociology \\
& Tradutor 6 & Sociology \\
\hline \multirow{2}{*}{ Grupo } & Tradutor 7 & Sociology \\
1998 & Tradutor 8 & Sociology \\
& Tradutor 9 & Sociology
\end{tabular}




$\begin{array}{ll}\text { Tradutor 10 } & \text { Sociology } \\ \text { Tradutor 11 } & \text { SOCIOLOGY } \\ \text { Tradutor 12 } & \text { (omitiu) }\end{array}$

Notas:

1-Onze ocorrências para Sociology

2-Uma omissão

58 - L.E.M. (Inglês)

\begin{tabular}{lll}
\hline & Tradutor 1 & Foreign Modern Language (English) \\
Grupo & Tradutor 2 & Modern Foreign Language (English) \\
1978 & Tradutor 3 & Modern Foreign Language (English) \\
& Tradutor 4 & (omitiu) \\
& Tradutor 5 & FML (English) \\
& Tradutor 6 & Modern Foreign Language (English) \\
\hline & Tradutor 7 & Modern Foreign Language (English) \\
Grupo & Tradutor 8 & Modern Foreign Language (English) \\
1998 & Tradutor 9 & (omitiu) English \\
& Tradutor 10 & Modern Foreign Language (English) \\
& Tradutor 11 & FOREIGN MODERN LANGUAGE (English) \\
& Tradutor 12 & Erro Impressão Foreign Language English
\end{tabular}

Notas:

1-Duas ocorrências para Foreign Modern Language (English)

2-Sete ocorrências para Modern Foreign Language (English), uma delas com falha na impressão (letras sobrepostas)

3-Uma omissão

3-Uma ocorrência com forma abreviada para FML (English)

4-Uma ocorrência para (English)

\begin{tabular}{lll} 
& $\mathbf{5 9}$ - & Parte Diversificada - total da carga horária \\
\hline & Tradutor 1 & DIVERSIFIED SYLLABUS - Total class hours \\
Grupo & Tradutor 2 & DIVERSIFIED PART - Total Course Load \\
1978 & Tradutor 3 & DIVERSIFIED PART - total hour load \\
& Tradutor 4 & (omitiu) \\
& Tradutor 5 & DIVERSIFIED CURRICULUM - total course hours \\
& Tradutor 6 & SUPPLEMENTARY CURRICULUM - Total Hours \\
\hline \multirow{4}{*}{ Grupo } & Tradutor 7 & Diversified Part - Total Class Hours \\
1998 & Tradutor 8 & Diversified Part - Full Hourly Load \\
& Tradutor 9 & Total hour load of the diversified part \\
& Tradutor 10 & Diversified Part - Total credit hours \\
& Tradutor 11 & DIVERSIFIED PART - total course load \\
& Tradutor 12 & DIVERSIFIED PART - total class hours
\end{tabular}

Nota: alto grau de dispersão

\begin{tabular}{|c|c|c|}
\hline \multirow{7}{*}{$\begin{array}{l}\text { Grupo } \\
1978\end{array}$} & Tradutor 1 & PROGRAM'S TOTAI CIASS HOURS \\
\hline & Tradutar? & \\
\hline & Iradutor 2 & Iotal Course Load of the Course \\
\hline & Tradutor 3 & PROGRAM TOTAL HOUR LOAD \\
\hline & Tradutor 4 & (omitiu) \\
\hline & Tradutor 5 & TOTAL COURSE HOUR LOAD \\
\hline & Tradutor 6 & TOTAL HOURS \\
\hline \multirow{6}{*}{$\begin{array}{l}\text { Grupo } \\
1998\end{array}$} & Tradutor 7 & Total Class Hours of the Course \\
\hline & Tradutor 8 & Full Hourly Load of the Program \\
\hline & Tradutor 9 & Total hour load of the course \\
\hline & Tradutor 10 & Total Credit Hours of Secondary Education \\
\hline & Tradutor 11 & TOTAL COURSE LOAD \\
\hline & Tradutor 12 & Total class hours of the course \\
\hline
\end{tabular}

Nota: alto grau de dispersão

\begin{tabular}{|c|c|c|}
\hline \multirow{7}{*}{$\begin{array}{l}\text { Grupo } \\
1978\end{array}$} & & nsino Religioso - NF \\
\hline & Tradutor 1 & Religion - (omitiu) \\
\hline & Tradutor 2 & Religion - NF \\
\hline & Tradutor 3 & RELIGION INSTRUCTION - NF \\
\hline & Tradutor 4 & (omitiu) \\
\hline & Tradutor 5 & RELIGIOUS EDUCATION - NF \\
\hline & Tradutor 6 & RELIGIOUS EDUCATION - NF \\
\hline
\end{tabular}




\begin{tabular}{lll}
\hline & Tradutor 7 & Religious Education - NF \\
Grupo & Tradutor 8 & Religious Teaching - NF \\
1998 & Tradutor 9 & Religion - NF \\
& Tradutor 10 & Religion - NF \\
& Tradutor 11 & RELIG. EDUCATION - NF \\
& Tradutor 12 & (omitiu)
\end{tabular}

Notas:

1-Quatro ocorrências para Religion

2-Uma ocorrência para Religion Instruction

3-Duas omissões

4-Três ocorrências para Religious Education

5-Uma ocorrência para Religious Teaching

6-Uma ocorrência para Relig. Education

\begin{tabular}{lll} 
& $\mathbf{6 2} \mathbf{-}$ & Total de Horas do Estágio Supervisionado \\
\hline & Tradutor 1 & Supervised training period: [blank] \\
Grupo & Tradutor 2 & (omitiu) \\
1978 & Tradutor 3 & $\begin{array}{l}\text { SUPERVISED INTERNSHIP TOTAL HOUR LOAD [nihil] } \\
\text { (omitiu) }\end{array}$ \\
& Tradutor 4 & TOTAL SUPERVISED TRAINING HOURS \\
& Tradutor 5 & TOTAL HOURS OF SUPERVISED TRAINING \\
\hline & Tradutor 6 & Total Hours of Supervised Internship \\
Grupo & Tradutor 7 & Full Hourly Load of the Supervised Training \\
1998 & Tradutor 8 & (omitiu) \\
& Tradutor 9 & (omitiu) \\
& Tradutor 10 & TOTAL HOURS IN SUPERVISED TRAINING \\
& Tradutor 11 & (omitiu)
\end{tabular}

Nota: alto grau de dispersão

\begin{tabular}{lll} 
& $\mathbf{6 3} \mathbf{-}$ & Estudos Realizados \\
\hline & Tradutor 1 & STUDIES COMPLETED \\
Grupo & Tradutor 2 & Courses Attended \\
1978 & Tradutor 3 & STUDIES ACCOMPLISHED \\
& Tradutor 4 & ACCOMPLISHED STUDIES \\
& Tradutor 5 & LEVELS OF COMPLETED EDUCATION \\
& Tradutor 6 & COURSES TAKEN \\
\hline \multirow{3}{*}{ Grupo } & Tradutor 7 & Studies Performed \\
1998 & Tradutor 8 & STUDIES PERFORMED \\
& Tradutor 9 & Studies Taken \\
& Tradutor 10 & Courses Taken \\
& Tradutor 11 & STUDIES PERFORMED \\
& Tradutor 12 & STUDIES PERFORMED
\end{tabular}

Notas:

1-Uma ocorrência para Studies Completed

2-Uma ocorrência para Courses Attended

3-Uma ocorrência para Studies Accomplished

4-Uma ocorrência para Accomplished Studies

5-Uma ocorrência para Levels of Completed Education

6-Duas ocorrências para Courses Taken

7-Quatro ocorrências para Studies Performed

8-Uma ocorrência para Studies Taken

\begin{tabular}{lll} 
& $\mathbf{6 4}$ - & Curso Anterior $-\mathbf{1}^{\circ}$ Grau \\
\hline & Tradutor 1 & (omitiu) - ELEMENTARY SCHOOL \\
Grupo & Tradutor 2 & (omitiu) - Primary School \\
1978 & Tradutor 3 & PREVIOUS PROGRAM - Elementary \& Junior High School \\
& Tradutor 4 & Previous Course - Elementary and Junior High School \\
& Tradutor 5 & PREVIOUS EDUCATION - Basic Education \\
& Tradutor 6 & PREVIOUS COURSE - Elementary-Middle School Education \\
\hline \multirow{3}{*}{ Grupo } & Tradutor 7 & Previous Course - Elementary and Middle School \\
1998 & Tradutor 8 & Previous Program - PRIMARY SCHOOL \\
& Tradutor 9 & Previous course - Elementary School \\
& Tradutor 10 & Previous Education: Primary Education \\
& Tradutor 11 & Previous Course: Elementary School \\
& Tradutor 12 & PREVIOUS COURSE: Grade School
\end{tabular}


Nota: alto grau de dispersão

\begin{tabular}{lll} 
& 65 - & Ano de Conclusão \\
\hline \multirow{4}{*}{ Grupo } & Tradutor 1 & Graduation \\
1978 & Tradutor 2 & Year of Completion \\
& Tradutor 3 & Year of Completion \\
& Tradutor 4 & Year of Conclusion \\
& Tradutor 5 & Completion Year \\
& Tradutor 6 & Year of Completion \\
\hline \multirow{3}{*}{ Grupo } & Tradutor 7 & Completion Year \\
1998 & Tradutor 8 & Year of Conclusion \\
& Tradutor 9 & Year of conclusion \\
& Tradutor 10 & Year of Conclusion \\
& Tradutor 11 & Completed \\
& Tradutor 12 & Year of Conclusion
\end{tabular}

Notas:

1-Uma ocorrência para Graduation

2-Três ocorrências para Year of Completion

3-Cinco ocorrências para Year of Conclusion

4-Duas ocorrências para Completion Year

5-Uma ocorrência para Completed

\begin{tabular}{lll} 
& \multicolumn{6}{c}{$\mathbf{6 6}-$} & Estabelecimento \\
\hline & Tradutor 1 & Name of School \\
Grupo & Tradutor 2 & School \\
1978 & Tradutor 3 & School \\
& Tradutor 4 & School \\
& Tradutor 5 & School \\
\hline & Tradutor 6 & School \\
\hline \multirow{3}{*}{ Grupo } & Tradutor 7 & Establishment \\
1998 & Tradutor 8 & School \\
& Tradutor 9 & Establishment \\
& Tradutor 10 & Establishment \\
& Tradutor 11 & Education Institution
\end{tabular}

Notas:

1-Uma ocorrência para Name of School

2-Seis ocorrências para School

3-Quatro ocorrências para Establishment

4-Uma ocorrência para Education Institution

\begin{tabular}{lll} 
& \multicolumn{1}{c}{$\mathbf{6 7}$ - } & Município \\
\hline & Tradutor 1 & City \\
Grupo & Tradutor 2 & Municipality \\
1978 & Tradutor 3 & City \\
& Tradutor 4 & City \\
& Tradutor 5 & Municipality \\
\hline & Tradutor 6 & City \\
\hline \multirow{4}{*}{ Grupo } & Tradutor 7 & City \\
1998 & Tradutor 8 & City \\
& Tradutor 9 & Municipality \\
& Tradutor 10 & Municipality \\
& Tradutor 11 & City \\
& Tradutor 12 & City
\end{tabular}

Notas:

1-Oito ocorrências para City

2-Quatro ocorrências para Municipality

\begin{tabular}{|c|c|c|}
\hline & & Estado \\
\hline & Tradutor 1 & State \\
\hline & Tradutor 2 & State \\
\hline Grupo & Tradutor 3 & State \\
\hline 1978 & Tradutor 4 & State \\
\hline & Tradutor 5 & State \\
\hline & Tradutor 6 & State \\
\hline
\end{tabular}




\begin{tabular}{lll}
\hline & Tradutor 7 & State \\
Grupo & Tradutor 8 & State \\
1998 & Tradutor 9 & State \\
& Tradutor 10 & State \\
& Tradutor 11 & State \\
& Tradutor 12 & State
\end{tabular}

Nota: sem dispersão

\begin{tabular}{lll} 
& & $\mathbf{6 9} \mathbf{- 1 9 9 5}$ \\
\hline & Tradutor 1 & 1995 \\
Grupo & Tradutor 2 & 1995 \\
1978 & Tradutor 3 & 1995 \\
& Tradutor 4 & 1995 \\
& Tradutor 5 & 1995 \\
& Tradutor 6 & 1995 \\
\hline \multirow{4}{*}{ Grupo } & Tradutor 7 & 1995 \\
1998 & Tradutor 8 & 1995 \\
& Tradutor 9 & 1995 \\
& Tradutor 10 & 1995 \\
& Tradutor 11 & 1995 \\
& Tradutor 12 & 1995
\end{tabular}

Nota: sem dispersão

\begin{tabular}{|c|c|c|}
\hline \multirow{7}{*}{$\begin{array}{l}\text { Grupo } \\
1978\end{array}$} & Tradutor 1 & EEPSG Prot- Euryaice Leroini \\
\hline & Tradutor 2 & EEPSG Prof.a Eurydice Zerbini \\
\hline & Tradutor 3 & E.E.P.S.G. Prof. Eurydice Zerbini [Prof. Eurydice Zerbini Elementary \& \\
\hline & & Junior High State Public School] \\
\hline & Tradutor 4 & "EEPSG Profa. Eurydice Zerbini" \\
\hline & Tradutor 5 & EEPSG Prof. Eurydice Zerbini \\
\hline & Tradutor 6 & EEPSG Profa. Eurydice Zerbini \\
\hline \multirow{6}{*}{$\begin{array}{l}\text { Grupo } \\
1998\end{array}$} & Tradutor 7 & $\begin{array}{l}\text { EEPSG Prof }{ }^{a} \text { Eurydice Zerbini [Public Elementary and High School Prof }{ }^{-}- \\
\text {Eurydice Zerbini] }\end{array}$ \\
\hline & Tradutor 8 & EEPSG PROF. EURYDICE ZERBINI \\
\hline & Tradutor 9 & EEPSG - Prof ${ }^{\mathrm{a}}$ Eurydice Zerbini \\
\hline & Tradutor 10 & EEPSG Prof ${ }^{a}$ Eurydice Zerbini \\
\hline & Tradutor 11 & EEPSG - Prof ${ }^{a}$ Eurydice Zerbini \\
\hline & Tradutor 12 & EEPSG Prof. ${ }^{a}$ Eurydice Zerbini \\
\hline
\end{tabular}

Nota: baixa dispersão, dois tradutores optaram por explicitar EEPSG que significa Escola Estadual de Primeiro e Segundo Graus.

71 - São Paulo - SP

\begin{tabular}{|c|c|c|}
\hline & Tradutor 1 & City and State of São Paulo \\
\hline & Tradutor 2 & São Paulo - SP \\
\hline Grupo & Tradutor 3 & São Paulo - S.P. [São Paulo] \\
\hline 1978 & Tradutor 4 & São Paulo - S.P. \\
\hline & Tradutor 5 & São Paulo - SP \\
\hline & Tradutor 6 & São Paulo - SP \\
\hline & Tradutor 7 & São Paulo - São Paulo \\
\hline & Tradutor 8 & SÃO PAULO - SP \\
\hline Grupo & Tradutor 9 & São Paulo - SP \\
\hline 1998 & Tradutor 10 & São Paulo - SP \\
\hline & Tradutor 11 & São Paulo - SP \\
\hline & Tradutor 12 & São Paulo - SP \\
\hline
\end{tabular}

Nota: baixa dispersão, dois tradutores apenas optaram por explicitar

72 - No $2^{\circ} \mathrm{Grau}$

\begin{tabular}{lll}
\hline & Tradutor 1 & SECONDARY SCHOOL [Senior High School] \\
Grupo & Tradutor 2 & Secondary School \\
1978 & Tradutor 3 & SENIOR HIGH SCHOOL \\
& Tradutor 4 & SENIOR HIGH SCHOOL \\
& Tradutor 5 & HIGH SCHOOL \\
& Tradutor 6 & HIGH SCHOOL EDUCATION \\
\hline
\end{tabular}




\begin{tabular}{lll}
\hline & Tradutor 7 & High School \\
Grupo & Tradutor 8 & IN SECONDARY SCHOOL \\
1998 & Tradutor 9 & High School \\
& Tradutor 10 & Secondary Education \\
& Tradutor 11 & High School \\
& Tradutor 12 & High School
\end{tabular}

Notas:

1-Três ocorrências para Secondary School, uma delas com explicitação

2-Duas ocorrências para Senior High School

3-Cinco ocorrências para High School

4-Uma ocorrência para High School Education

5-Uma ocorrência para Secondary Education

\begin{tabular}{|c|c|c|}
\hline \multirow{7}{*}{$\begin{array}{l}\text { Grupo } \\
1978\end{array}$} & & \\
\hline & | radutor 1 & year \\
\hline & Tradutor 2 & Year \\
\hline & Tradutor 3 & Grade \\
\hline & Tradutor 4 & Grade \\
\hline & Tradutor 5 & Grade \\
\hline & Tradutor 6 & Grade \\
\hline \multirow{6}{*}{$\begin{array}{l}\text { Grupo } \\
1998\end{array}$} & Tradutor 7 & Grade \\
\hline & Tradutor 8 & Grade \\
\hline & Tradutor 9 & Grade \\
\hline & Tradutor 10 & School Year \\
\hline & Tradutor 11 & Grade \\
\hline & Tradutor 12 & Grade \\
\hline
\end{tabular}

Notas:

1-Duas ocorrências para Year

2-Nove ocorrências para Grade

3-Uma ocorrência para School Year

\begin{tabular}{lll} 
& 74 - & Ano \\
\hline & Tradutor 1 & (omitiu) \\
Grupo & Tradutor 2 & School Year \\
1978 & Tradutor 3 & Year \\
& Tradutor 4 & School Year \\
& Tradutor 5 & Year \\
\hline & Tradutor 6 & Year \\
\hline \multirow{3}{*}{ Grupo } & Tradutor 7 & Year \\
1998 & Tradutor 8 & Year \\
& Tradutor 9 & Year \\
& Tradutor 10 & Year \\
& Tradutor 11 & Year
\end{tabular}

Notas:

1-Uma omissão

2-Duas ocorrências para School Year

3-Nove ocorrências para Year

75 - Estabelecimento

\begin{tabular}{lll} 
& & \\
& Tradutor 1 & (omitiu) \\
Grupo & Tradutor 2 & School \\
1978 & Tradutor 3 & School \\
& Tradutor 4 & School \\
& Tradutor 5 & School \\
& Tradutor 6 & School \\
\hline & Tradutor 7 & Establishment \\
Grupo & Tradutor 8 & School \\
1998 & Tradutor 9 & Establishment \\
& Tradutor 10 & Establishment \\
& Tradutor 11 & Education Institution \\
& Tradutor 12 & Establishment
\end{tabular}

Nota: item repetido (igual ao número 66). Tradutor 1 omitiu neste item, embora tenha traduzido no item 66. 


\begin{tabular}{lll} 
& 76 - & Município \\
\hline & Tradutor 1 & (omitiu) \\
Grupo & Tradutor 2 & Municipality \\
1978 & Tradutor 3 & City \\
& Tradutor 4 & City \\
& Tradutor 5 & Municipality \\
\hline \multirow{4}{*}{ Grupo } & Tradutor 6 & City \\
1998 & Tradutor 7 & City \\
& Tradutor 8 & City \\
& Tradutor 9 & Municipality \\
& Tradutor 10 & Municipality \\
& Tradutor 11 & City
\end{tabular}

Nota: item repetido (igual ao número 67). Tradutor 1 omitiu neste item, embora tenha traduzido no item 67.

\begin{tabular}{|c|c|c|}
\hline & & Estado \\
\hline & Tradutor 1 & (omitiu) \\
\hline & Tradutor 2 & State \\
\hline Grupo & Tradutor 3 & State \\
\hline 1978 & Tradutor 4 & State \\
\hline & Tradutor 5 & State \\
\hline & Tradutor 6 & State \\
\hline & Tradutor 7 & State \\
\hline & Tradutor 8 & State \\
\hline Grupo & Tradutor 9 & State \\
\hline 1998 & Tradutor 10 & State \\
\hline & Tradutor 11 & State \\
\hline & Tradutor 12 & State \\
\hline
\end{tabular}

Nota: item repetido (igual ao número 68). Tradutor 1 omitiu neste item, embora tenha traduzido no item 68.

\begin{tabular}{|c|c|c|}
\hline \multicolumn{3}{|c|}{$78-1^{\mathrm{a}}-1996$} \\
\hline \multirow{6}{*}{$\begin{array}{l}\text { Grupo } \\
1978\end{array}$} & Tradutor 1 & $1^{\text {st }}-1996$ \\
\hline & Tradutor 2 & $1^{\text {st }}-1996$ \\
\hline & Tradutor 3 & $1^{\text {st }}-1996$ \\
\hline & Tradutor 4 & 1st - 1996 \\
\hline & Tradutor 5 & $1^{\text {st }}$ grade -1996 \\
\hline & Tradutor 6 & 1 st - 1996 \\
\hline \multirow{6}{*}{$\begin{array}{l}\text { Grupo } \\
1998\end{array}$} & Tradutor 7 & $1^{\text {st }}-1996$ \\
\hline & Tradutor 8 & $1^{\text {st }}-1996$ \\
\hline & Tradutor 9 & $1^{\text {st }}-1996$ \\
\hline & Tradutor 10 & $1^{\text {st }}-1996$ \\
\hline & Tradutor 11 & First - 1996 \\
\hline & Tradutor 12 & $1^{\text {st }}-1996$ \\
\hline
\end{tabular}

Nota: baixo grau de dispersão

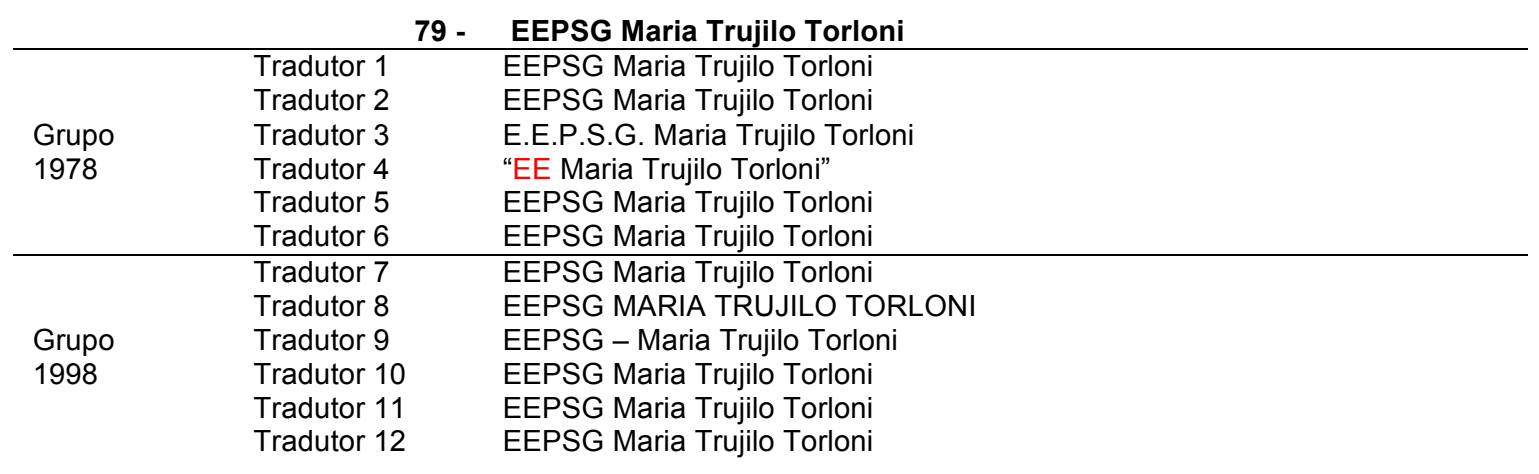

Nota: uma ocorrência de erro 
80 - S.C. Sul - SP

\begin{tabular}{lll}
\hline & Tradutor 1 & São Caetano do Sul, São Paulo \\
Grupo & Tradutor 2 & São Caetano do Sul - SP \\
1978 & Tradutor 3 & S.C. Sul - S.P. \\
& Tradutor 4 & São Caetano do Sul - S.P. \\
& Tradutor 5 & S.C. Sul - SP \\
& Tradutor 6 & S.C. Sul - SP \\
\hline \multirow{3}{*}{ Grupo } & Tradutor 7 & São Caetano do Sul - São Paulo \\
1998 & Tradutor 8 & S. Caetano do Sul - SP \\
& Tradutor 9 & São Caetano do Sul - SP \\
& Tradutor 10 & S.C. Sul - SP \\
& Tradutor 11 & São Paulo - SP \\
& Tradutor 12 & S.C. do Sul - SP
\end{tabular}

Nota: dispersão com vários tradutores tendo optado pela explicitação. Uma ocorrência de erro.

\begin{tabular}{|c|c|c|}
\hline \multicolumn{3}{|c|}{$81-2^{a}-1997$} \\
\hline \multirow{6}{*}{$\begin{array}{l}\text { Grupo } \\
1978\end{array}$} & Tradutor 1 & $2^{\text {nd }}-1997$ \\
\hline & Tradutor 2 & $2^{\text {nd }}-1997$ \\
\hline & Tradutor 3 & $2^{\text {nd }}-1997$ \\
\hline & Tradutor 4 & 2nd - 1997 \\
\hline & Tradutor 5 & $2^{\text {nd }}$ grade -1997 \\
\hline & Tradutor 6 & 2nd - 1997 \\
\hline \multirow{6}{*}{$\begin{array}{l}\text { Grupo } \\
1998\end{array}$} & Tradutor 7 & $2^{\text {nd }}-1997$ \\
\hline & Tradutor 8 & $2^{\text {nd }}-1997$ \\
\hline & Tradutor 9 & $2^{\text {nd }}-1997$ \\
\hline & Tradutor 10 & $2^{\text {nd }}-1997$ \\
\hline & Tradutor 11 & Second - 1997 \\
\hline & Tradutor 12 & $2^{\text {nd }}-1997$ \\
\hline
\end{tabular}

Nota: baixo grau de dispersão

\begin{tabular}{lll} 
& 82 & EEPSG Maria Trujilo Torloni \\
\hline & Tradutor 1 & EEPSG Maria Trujilo Torloni \\
Grupo & Tradutor 2 & EEPSG Maria Trujilo Torloni \\
1978 & Tradutor 3 & E.E.P.S.G. Maria Trujilo Torloni \\
& Tradutor 4 & "EE Maria Trujilo Torloni” \\
& Tradutor 5 & EEPSG Maria Trujilo Torloni \\
& Tradutor 6 & EEPSG Maria Trujilo Torloni \\
\hline & Tradutor 7 & EEPSG Maria Trujilo Torloni \\
Grupo & Tradutor 8 & EEPSG MARIA TRUJILO TORLONI \\
1998 & Tradutor 9 & EEPSG - Maria Trujilo Torloni \\
& Tradutor 10 & EEPSG Maria Trujilo Torloni \\
& Tradutor 11 & EEPSG Maria Trujilo Torloni \\
& Tradutor 12 & EEPSG Maria Trujilo Torloni
\end{tabular}

Nota: uma ocorrência de erro

83 - S.C. Sul - SP

\begin{tabular}{|c|c|c|}
\hline & Tradutor 1 & São Caetano do Sul. São Paulo \\
\hline & Tradutor 2 & São Caetano do Sul - SP \\
\hline Grupo & Tradutor 3 & S.C. Sul - S.P. \\
\hline 1978 & Tradutor 4 & São Caetano do Sul - S.P. \\
\hline & Tradutor 5 & S.C. Sul - SP \\
\hline & Tradutor 6 & S.C. Sul - SP \\
\hline & Tradutor 7 & São Caetano do Sul - São Paulo \\
\hline & Tradutor 8 & S. Caetano do Sul - SP \\
\hline Grupo & Tradutor 9 & São Caetano do Sul - SP \\
\hline 1998 & Tradutor 10 & S.C. Sul - SP \\
\hline & Tradutor 11 & São Paulo - SP \\
\hline & Tradutor 12 & S.C. do Sul - SP \\
\hline
\end{tabular}

Nota: dispersão com vários tradutores tendo optado pela explicitação. Uma ocorrência de erro. 


\begin{tabular}{|c|c|c|}
\hline \multicolumn{3}{|c|}{$84-3^{a}-1998$} \\
\hline \multirow{6}{*}{$\begin{array}{l}\text { Grupo } \\
1978\end{array}$} & Tradutor 1 & $3^{\text {rd }}-1998$ \\
\hline & Tradutor 2 & $3^{\text {rd }}-1998$ \\
\hline & Tradutor 3 & $3^{\text {rd }}-1998$ \\
\hline & Tradutor 4 & 3rd - 1998 \\
\hline & Tradutor 5 & $3^{\text {rd }}$ grade -1998 \\
\hline & Tradutor 6 & $3 r d-1998$ \\
\hline \multirow{6}{*}{$\begin{array}{l}\text { Grupo } \\
1998\end{array}$} & Tradutor 7 & $3^{\text {rd }}-1998$ \\
\hline & Tradutor 8 & $3^{\text {rd }}-1998$ \\
\hline & Tradutor 9 & $3^{\text {rd }}-1998$ \\
\hline & Tradutor 10 & $3^{\text {rd }}-1998$ \\
\hline & Tradutor 11 & Third - 1998 \\
\hline & Tradutor 12 & $3^{\text {rd }}-1998$ \\
\hline
\end{tabular}

Nota: baixo grau de dispersão

\begin{tabular}{lll} 
& 85 - & EE. Maria Trujilo Torloni \\
\hline \multirow{4}{*}{ Grupo } & Tradutor 1 & EE Maria Trujilo Torloni \\
1978 & Tradutor 2 & EE Maria Trujilo Torloni \\
& Tradutor 3 & E.E. Maria Trujilo Torloni \\
& Tradutor 4 & "E.E. Maria Trujilo Torloni" \\
& Tradutor 5 & EE. Maria Trujilo Torloni \\
& Tradutor 6 & EE. Maria Trujilo Torloni \\
\hline \multirow{3}{*}{ Grupo } & Tradutor 7 & EE. Maria Trujilo Torloni \\
1998 & Tradutor 8 & EE. MARIA TRUJILO TORLONI \\
& Tradutor 9 & EEPSG - Maria Trujilo Torloni \\
& Tradutor 10 & EE Maria Trujilo Torloni \\
& Tradutor 11 & EE Maria Trujilo Torloni \\
& Tradutor 12 & EE. Maria Trujilo Torloni
\end{tabular}

Nota: uma ocorrência de erro

\begin{tabular}{|c|c|c|}
\hline \multicolumn{3}{|c|}{86 - S.C. Sul - SP } \\
\hline \multirow{6}{*}{$\begin{array}{l}\text { Grupo } \\
1978\end{array}$} & Tradutor 1 & São Caetano do Sul, São Paulo \\
\hline & Tradutor 2 & São Caetano do Sul - SP \\
\hline & Tradutor 3 & S.C. Sul - S.P. \\
\hline & Tradutor 4 & São Caetano do Sul - S.P. \\
\hline & Tradutor 5 & S.C. Sul - SP \\
\hline & Tradutor 6 & S.C. Sul - SP \\
\hline \multirow{6}{*}{$\begin{array}{l}\text { Grupo } \\
1998\end{array}$} & Tradutor 7 & São Caetano do Sul - São Paulo \\
\hline & Tradutor 8 & S. Caetano do Sul - SP \\
\hline & Tradutor 9 & São Caetano do Sul - SP \\
\hline & Tradutor 10 & S.C. Sul - SP \\
\hline & Tradutor 11 & São Paulo - SP \\
\hline & Tradutor 12 & S.C. do Sul - SP \\
\hline
\end{tabular}

Nota: dispersão com vários tradutores tendo optado pela explicitação. Uma ocorrência de erro.

\begin{tabular}{lll} 
& $\mathbf{8 7}$ - & Transferência durante o período letivo \\
\hline & Tradutor 1 & TRANSFER [blank] \\
Grupo & Tradutor 2 & (omitiu) \\
1978 & Tradutor 3 & TRANSFER DURING SCHOOL PERIOD [not applicable] \\
& Tradutor 4 & (omitiu) \\
& Tradutor 5 & TRANSFER DURING THE SCHOOL YEAR \\
& Tradutor 6 & TRANSFER DURING THE SCHOOL PERIOD [N.T.] (com explicação) \\
\hline \multirow{4}{*}{ Grupo } & Tradutor 7 & Transfer during the School year \\
1998 & Tradutor 8 & TRANSFER DURING THE SCHOOL PERIOD (blank table) \\
& Tradutor 9 & (omissis) \\
& Tradutor 10 & (omitiu) \\
& Tradutor 11 & (omitiu) \\
& Tradutor 12 & (omitiu) [N.T.] (com explicação)
\end{tabular}

Notas:

1-Uma ocorrência para Transfer [blank]

2-Seis ocorrências de omissão, uma com explicação

3-Uma ocorrência para Transfer during School Period [not applicable]

4-Duas ocorrências para Transfer during the School Year

5-Duas ocorrências para Transfer during the School Period com explicação 
Nos itens 88 a 121 abaixo, 10 tradutores omitiram esse trecho referente à Transferência. No documento original, o quadro com as disciplinas está em branco e contém uma linha transversal inutilizando os campos.

\begin{tabular}{|c|c|c|}
\hline \multirow{7}{*}{$\begin{array}{l}\text { Grupo } \\
1978\end{array}$} & & \\
\hline & Tradutor 1 & (omitiu) \\
\hline & Tradutor 2 & (omitiu) \\
\hline & Tradutor 3 & (omitiu) \\
\hline & Tradutor 4 & (omitiu) \\
\hline & Tradutor 5 & Student's achievements \\
\hline & Tradutor 6 & (omitiu) \\
\hline \multirow{6}{*}{$\begin{array}{l}\text { Grupo } \\
1998\end{array}$} & Tradutor 7 & Student's School Performance \\
\hline & Tradutor 8 & (omitiu) \\
\hline & Tradutor 9 & (omitiu) \\
\hline & Tradutor 10 & (omitiu) \\
\hline & Tradutor 11 & (omitiu) \\
\hline & Tradutor 12 & (omitiu) \\
\hline
\end{tabular}

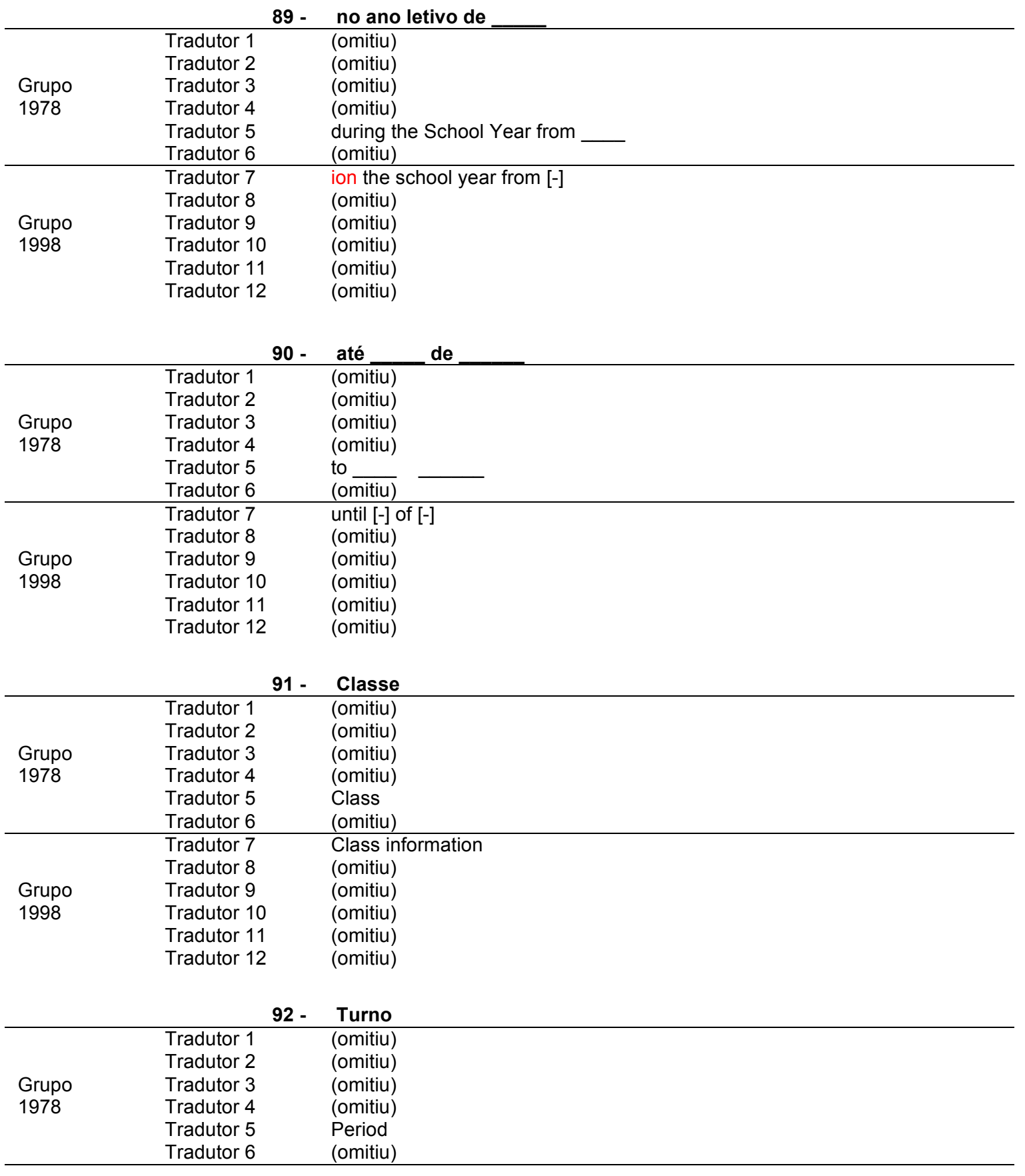




\begin{tabular}{lll}
\hline & Tradutor 7 & Shift \\
Grupo & Tradutor 8 & (omitiu) \\
1998 & Tradutor 9 & (omitiu) \\
& Tradutor 10 & (omitiu) \\
& Tradutor 11 & (omitiu) \\
& Tradutor 12 & (omitiu)
\end{tabular}

\begin{tabular}{|c|c|c|}
\hline & $93-$ & Grau \\
\hline \multirow{6}{*}{$\begin{array}{l}\text { Grupo } \\
1978\end{array}$} & Tradutor 1 & (omitiu) \\
\hline & Tradutor 2 & (omitiu) \\
\hline & Tradutor 3 & (omitiu) \\
\hline & Tradutor 4 & (omitiu) \\
\hline & Tradutor 5 & Level \\
\hline & Tradutor 6 & (omitiu) \\
\hline \multirow{7}{*}{$\begin{array}{l}\text { Grupo } \\
1998\end{array}$} & Tradutor 7 & Degree \\
\hline & Tradutor 8 & (omitiu) \\
\hline & Tradutor 9 & (omitiu) \\
\hline & Tradutor 10 & (omitiu) \\
\hline & Tradutor 11 & (omitiu) \\
\hline & Tradutor 12 & (omitiu) \\
\hline & $94-$ & Série \\
\hline \multirow{6}{*}{$\begin{array}{l}\text { Grupo } \\
1978\end{array}$} & Tradutor 1 & (omitiu) \\
\hline & Tradutor 2 & (omitiu) \\
\hline & Tradutor 3 & (omitiu) \\
\hline & Tradutor 4 & (omitiu) \\
\hline & Tradutor 5 & Grade \\
\hline & Tradutor 6 & (omitiu) \\
\hline \multirow{7}{*}{$\begin{array}{l}\text { Grupo } \\
1998\end{array}$} & Tradutor 7 & Grade \\
\hline & Tradutor 8 & (omitiu) \\
\hline & Tradutor 9 & (omitiu) \\
\hline & Tradutor 10 & (omitiu) \\
\hline & Tradutor 11 & (omitiu) \\
\hline & Tradutor 12 & (omitiu) \\
\hline & $95-$ & Turma \\
\hline \multirow{6}{*}{$\begin{array}{l}\text { Grupo } \\
1978\end{array}$} & Tradutor 1 & (omitiu) \\
\hline & Tradutor 2 & (omitiu) \\
\hline & Tradutor 3 & (omitiu) \\
\hline & Tradutor 4 & (omitiu) \\
\hline & Tradutor 5 & Class \\
\hline & Tradutor 6 & (omitiu) \\
\hline \multirow{7}{*}{$\begin{array}{l}\text { Grupo } \\
1998\end{array}$} & Tradutor 7 & Group \\
\hline & Tradutor 8 & (omitiu) \\
\hline & Tradutor 9 & (omitiu) \\
\hline & Tradutor 10 & (omitiu) \\
\hline & Tradutor 11 & (omitiu) \\
\hline & Tradutor 12 & (omitiu) \\
\hline & $96-$ & $\mathbf{N}^{\circ}$ de chamada \\
\hline \multirow{6}{*}{$\begin{array}{l}\text { Grupo } \\
1978\end{array}$} & Tradutor 1 & (omitiu) \\
\hline & Tradutor 2 & (omitiu) \\
\hline & Tradutor 3 & (omitiu) \\
\hline & Tradutor 4 & (omitiu) \\
\hline & Tradutor 5 & Roll No. \\
\hline & Tradutor 6 & (omitiu) \\
\hline \multirow{6}{*}{$\begin{array}{l}\text { Grupo } \\
1998\end{array}$} & Tradutor 7 & Roll Call Number \\
\hline & Tradutor 8 & (omitiu) \\
\hline & Tradutor 9 & (omitiu) \\
\hline & Tradutor 10 & (omitiu) \\
\hline & Tradutor 11 & (omitiu) \\
\hline & Tradutor 12 & (omitiu) \\
\hline
\end{tabular}


97 - Componentes Curriculares

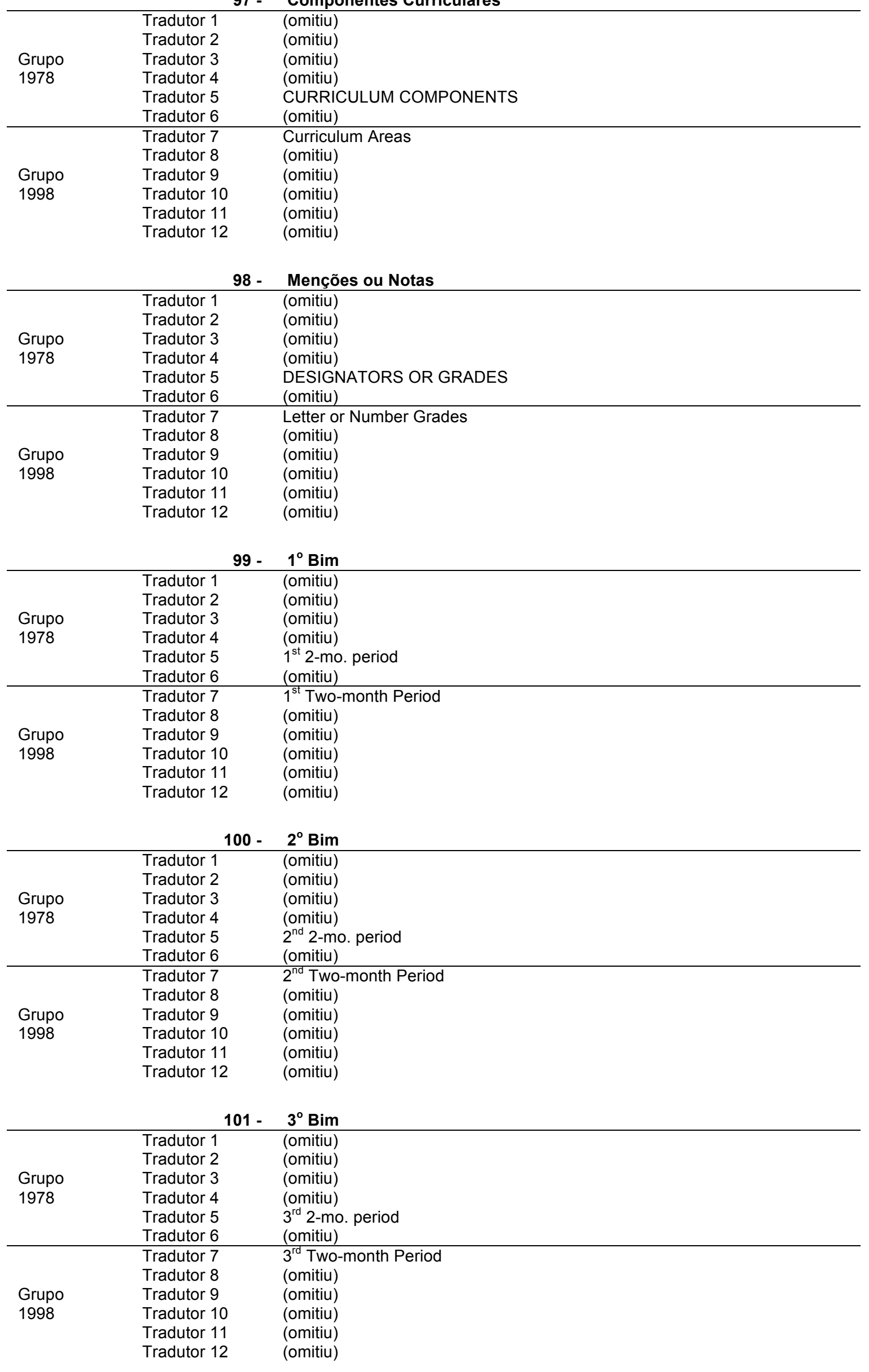




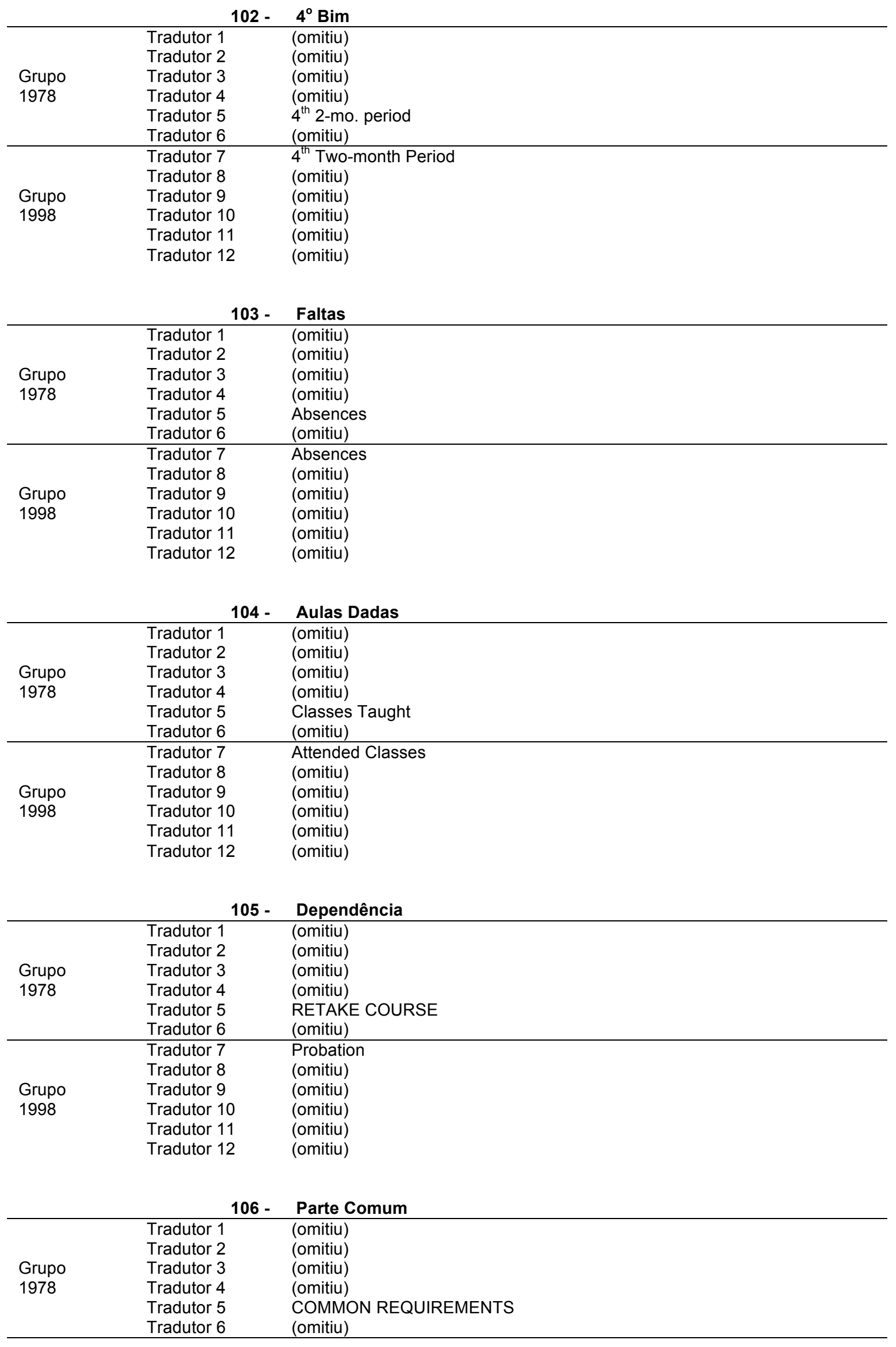




\begin{tabular}{lll}
\hline & Tradutor 7 & Common Par \\
Grupo & Tradutor 8 & (omitiu) \\
1998 & Tradutor 9 & (omitiu) \\
& Tradutor 10 & (omitiu) \\
& Tradutor 11 & (omitiu) \\
& Tradutor 12 & (omitiu)
\end{tabular}

107 - Língua Portuguesa e Literatura

\begin{tabular}{|c|c|c|}
\hline \multirow{6}{*}{$\begin{array}{l}\text { Grupo } \\
1978\end{array}$} & Tradutor 1 & (omitiu) \\
\hline & Tradutor 2 & (omitiu) \\
\hline & Tradutor 3 & (omitiu) \\
\hline & Tradutor 4 & (omitiu) \\
\hline & Tradutor 5 & PORTUGUESE LANGUAGE AND LITERATURE \\
\hline & Tradutor 6 & (omitiu) \\
\hline \multirow{7}{*}{$\begin{array}{l}\text { Grupo } \\
1998\end{array}$} & Tradutor 7 & Portuguese and Literature \\
\hline & Tradutor 8 & (omitiu) \\
\hline & Tradutor 9 & (omitiu) \\
\hline & Tradutor 10 & (omitiu) \\
\hline & Tradutor 11 & (omitiu) \\
\hline & Tradutor 12 & (omitiu) \\
\hline & $108-$ & História \\
\hline \multirow{6}{*}{$\begin{array}{l}\text { Grupo } \\
1978\end{array}$} & Tradutor 1 & (omitiu) \\
\hline & Tradutor 2 & (omitiu) \\
\hline & Tradutor 3 & (omitiu) \\
\hline & Tradutor 4 & (omitiu) \\
\hline & Tradutor 5 & HISTORY \\
\hline & Tradutor 6 & (omitiu) \\
\hline \multirow{7}{*}{$\begin{array}{l}\text { Grupo } \\
1998\end{array}$} & Tradutor 7 & History \\
\hline & Tradutor 8 & (omitiu) \\
\hline & Tradutor 9 & (omitiu) \\
\hline & Tradutor 10 & (omitiu) \\
\hline & Tradutor 11 & (omitiu) \\
\hline & Tradutor 12 & (omitiu) \\
\hline & 109 - & Geografia \\
\hline \multirow{6}{*}{$\begin{array}{l}\text { Grupo } \\
1978\end{array}$} & Tradutor 1 & (omitiu) \\
\hline & Tradutor 2 & (omitiu) \\
\hline & Tradutor 3 & (omitiu) \\
\hline & Tradutor 4 & (omitiu) \\
\hline & Tradutor 5 & GEOGRAPHY \\
\hline & Tradutor 6 & (omitiu) \\
\hline \multirow{7}{*}{$\begin{array}{l}\text { Grupo } \\
1998\end{array}$} & Tradutor 7 & Geography \\
\hline & Tradutor 8 & (omitiu) \\
\hline & Tradutor 9 & (omitiu) \\
\hline & Tradutor 10 & (omitiu) \\
\hline & Tradutor 11 & (omitiu) \\
\hline & Tradutor 12 & (omitiu) \\
\hline & $110-$ & Física \\
\hline \multirow{6}{*}{$\begin{array}{l}\text { Grupo } \\
1978\end{array}$} & Tradutor 1 & (omitiu) \\
\hline & Tradutor 2 & (omitiu) \\
\hline & Tradutor 3 & (omitiu) \\
\hline & Tradutor 4 & (omitiu) \\
\hline & Tradutor 5 & PHYSICS \\
\hline & Tradutor 6 & (omitiu) \\
\hline \multirow{6}{*}{$\begin{array}{l}\text { Grupo } \\
1998\end{array}$} & Tradutor 7 & Physics \\
\hline & Tradutor 8 & (omitiu) \\
\hline & Tradutor 9 & (omitiu) \\
\hline & Tradutor 10 & (omitiu) \\
\hline & Tradutor 11 & (omitiu) \\
\hline & Tradutor 12 & (omitiu) \\
\hline
\end{tabular}


111 - Química

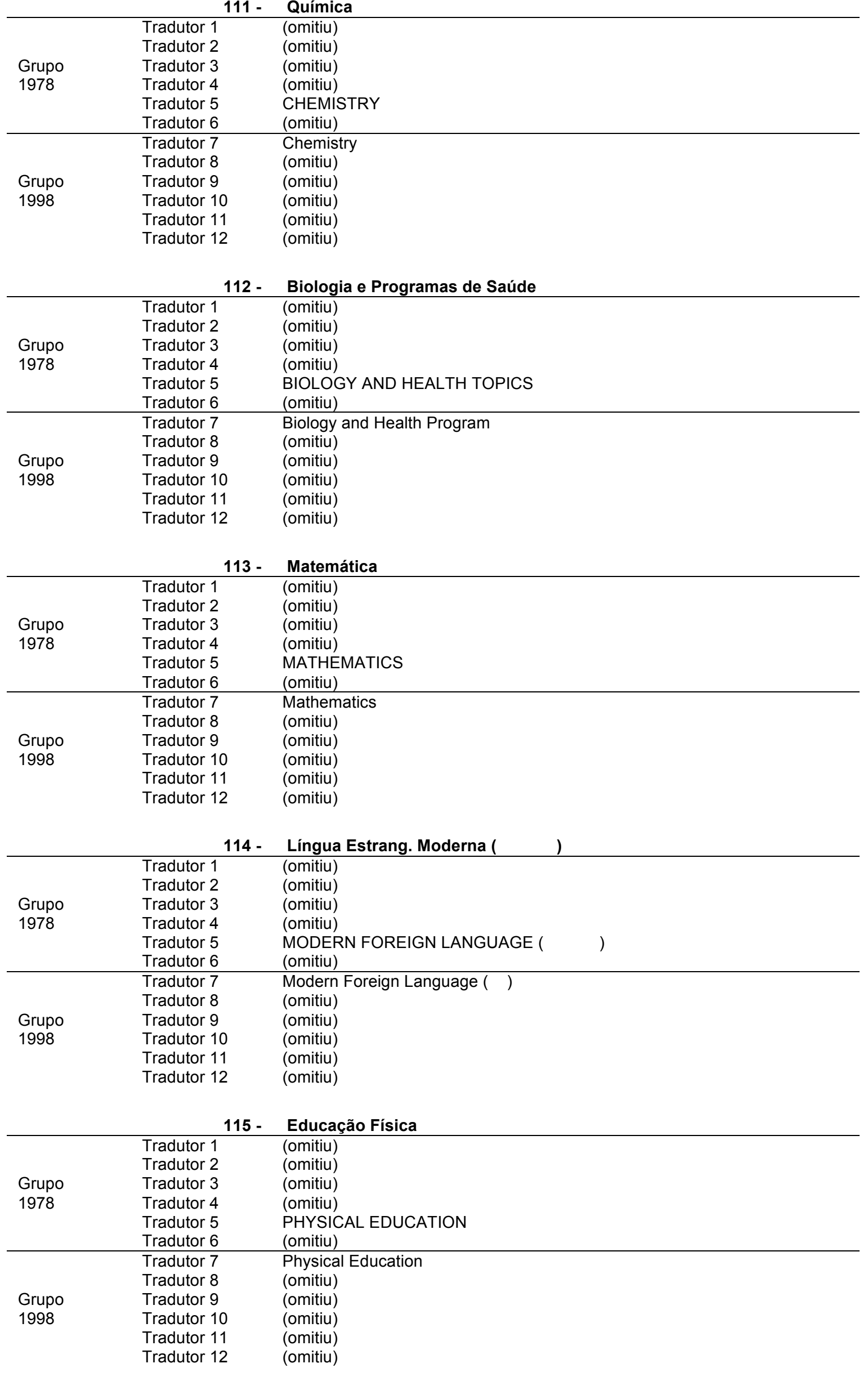




\begin{tabular}{|c|c|c|}
\hline & Tradutor 1 & (omitiu) \\
\hline & Tradutor 2 & (omitiu) \\
\hline \multirow{6}{*}{$\begin{array}{l}\text { Grupo } \\
1978\end{array}$} & Tradutor 3 & (omitiu) \\
\hline & Tradutor 4 & (omitiu) \\
\hline & Tradutor 5 & ART EDUCATION \\
\hline & Tradutor 6 & (omitiu) \\
\hline & Tradutor 7 & Arts \\
\hline & Tradutor 8 & (omitiu) \\
\hline \multirow{7}{*}{$\begin{array}{l}\text { Grupo } \\
1998\end{array}$} & Tradutor 9 & (omitiu) \\
\hline & Tradutor 10 & (omitiu) \\
\hline & Tradutor 11 & (omitiu) \\
\hline & Tradutor 12 & (omitiu) \\
\hline & $117-$ & Educação Moral e Cívica \\
\hline & Tradutor 1 & (omitiu) \\
\hline & Tradutor 2 & (omitiu) \\
\hline \multirow{6}{*}{$\begin{array}{l}\text { Grupo } \\
1978\end{array}$} & Tradutor 3 & (omitiu) \\
\hline & Tradutor 4 & (omitiu) \\
\hline & Tradutor 5 & MORAL AND CIVIC EDUCATION \\
\hline & Tradutor 6 & (omitiu) \\
\hline & Tradutor 7 & Civil and Moral Education \\
\hline & Tradutor 8 & (omitiu) \\
\hline \multirow{7}{*}{$\begin{array}{l}\text { Grupo } \\
1998\end{array}$} & Tradutor 9 & (omitiu) \\
\hline & Tradutor 10 & (omitiu) \\
\hline & Tradutor 11 & (omitiu) \\
\hline & Tradutor 12 & (omitiu) \\
\hline & $118-$ & Parte Diversificada \\
\hline & Tradutor 1 & (omitiu) \\
\hline & Tradutor 2 & (omitiu) \\
\hline \multirow{6}{*}{$\begin{array}{l}\text { Grupo } \\
1978\end{array}$} & Tradutor 3 & (omitiu) \\
\hline & Tradutor 4 & (omitiu) \\
\hline & Tradutor 5 & DIVERSIFIED PART (left blank) \\
\hline & Tradutor 6 & (omitiu) \\
\hline & Tradutor 7 & Diversified Part \\
\hline & Tradutor 8 & (omitiu) \\
\hline \multirow{7}{*}{$\begin{array}{l}\text { Grupo } \\
1998\end{array}$} & Tradutor 9 & (omitiu) \\
\hline & Tradutor 10 & (omitiu) \\
\hline & Tradutor 11 & (omitiu) \\
\hline & Tradutor 12 & (omitiu) \\
\hline & $119-$ & Ensino Religioso \\
\hline & Tradutor 1 & (omitiu) \\
\hline & Tradutor 2 & (omitiu) \\
\hline \multirow{6}{*}{$\begin{array}{l}\text { Grupo } \\
1978\end{array}$} & Tradutor 3 & (omitiu) \\
\hline & Tradutor 4 & (omitiu) \\
\hline & Tradutor 5 & Religious Education \\
\hline & Tradutor 6 & (omitiu) \\
\hline & Tradutor 7 & Religious Education \\
\hline & Tradutor 8 & (omitiu) \\
\hline \multirow{7}{*}{$\begin{array}{l}\text { Grupo } \\
1998\end{array}$} & Tradutor 9 & (omitiu) \\
\hline & Tradutor 10 & (omitiu) \\
\hline & Tradutor 11 & (omitiu) \\
\hline & Tradutor 12 & (omitiu) \\
\hline & $120-$ & $F(1)$ NF ( ) \\
\hline & Tradutor 1 & (omitiu) \\
\hline & Tradutor 2 & (omitiu) \\
\hline \multirow{6}{*}{$\begin{array}{l}\text { Grupo } \\
1978\end{array}$} & Tradutor 3 & (omitiu) \\
\hline & Tradutor 4 & (omitiu) \\
\hline & Tradutor 5 & F ( ) NF ( ) \\
\hline & Tradutor 6 & (omitiu) \\
\hline & Tradutor 7 & $F[-] \quad N F[-]$ \\
\hline & Tradutor 8 & (omitiu) \\
\hline \multirow{4}{*}{$\begin{array}{l}\text { Grupo } \\
1998\end{array}$} & Tradutor 9 & (omitiu) \\
\hline & Tradutor 10 & (omitiu) \\
\hline & Tradutor 11 & (omitiu) \\
\hline & Tradutor 12 & (omitiu) \\
\hline
\end{tabular}


121 - Estágio Supervisionado (Carga Horária)

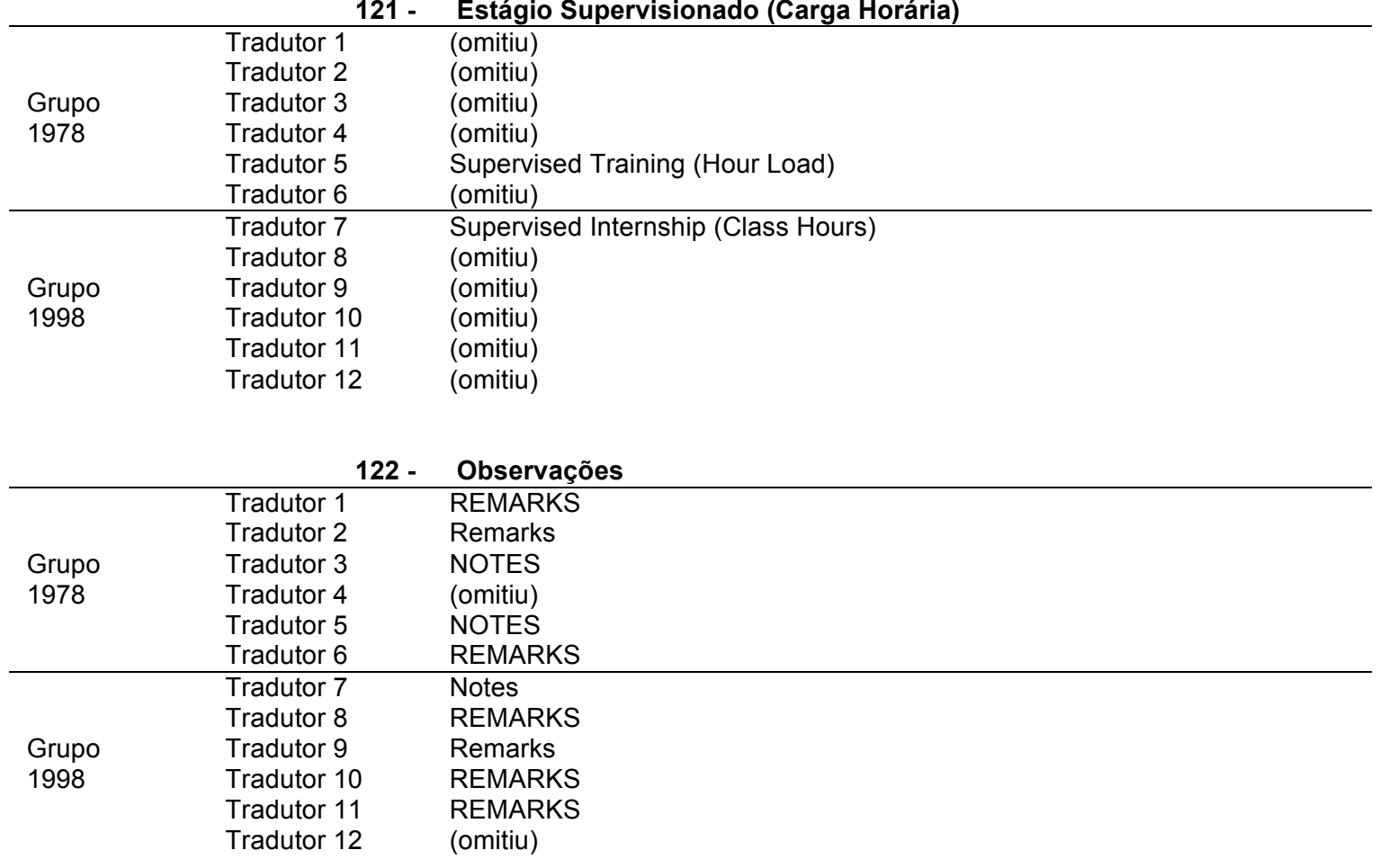

Notas:

1-Sete ocorrências para Remarks

2-Três ocorrências para Notes

3-Duas omissões

123 - 1. Os asteriscos indicam que a promoção do aluno,

\begin{tabular}{|c|c|c|}
\hline \multirow{6}{*}{$\begin{array}{l}\text { Grupo } \\
1978\end{array}$} & Tradutor 1 & 1. Asterisks indicate that (omitiu) \\
\hline & Tradutor 2 & 1. The asterisks indicate that the student's evaluation \\
\hline & Tradutor 3 & 1. Asterisks indicate that the student's promotion \\
\hline & Tradutor 4 & (omitiu) \\
\hline & Tradutor 5 & 1. Courses marked with an asterisk (omitiu) \\
\hline & Tradutor 6 & The asterisks indicate that the student's promotion, \\
\hline \multirow{6}{*}{$\begin{array}{l}\text { Grupo } \\
1998\end{array}$} & Tradutor 7 & 1. The asterisk indicates that the student's approval \\
\hline & Tradutor 8 & 1. Asterisks indicate the student's promotion \\
\hline & Tradutor 9 & (omitiu) \\
\hline & Tradutor 10 & 1. Asterisks indicate that the approval of the student \\
\hline & Tradutor 11 & 1. Asterisks indicate that the promotion of the student \\
\hline & Tradutor 12 & (omitiu) \\
\hline
\end{tabular}

Nota: alto grau de dispersão

124 - nos respectivos componentes curriculares,

\begin{tabular}{|c|c|c|}
\hline \multirow{6}{*}{$\begin{array}{l}\text { Grupo } \\
1978\end{array}$} & Tradutor 1 & subject approval \\
\hline & Tradutor 2 & in the respective curricular component \\
\hline & Tradutor 3 & in the relevant curricular components \\
\hline & Tradutor 4 & (omitiu) \\
\hline & Tradutor 5 & in the curriculum, \\
\hline & Tradutor 6 & in the respective curricular components \\
\hline \multirow{6}{*}{$\begin{array}{l}\text { Grupo } \\
1998\end{array}$} & Tradutor 7 & (omitiu) \\
\hline & Tradutor 8 & in the corresponding subjects \\
\hline & Tradutor 9 & (omitiu) \\
\hline & Tradutor 10 & in the relevant subjects \\
\hline & Tradutor 11 & In the respective curricular components \\
\hline & Tradutor 12 & (omitiu) \\
\hline
\end{tabular}

Notas: alto grau de dispersão 
125 - decorre apenas de apuração da assiduidade.

\begin{tabular}{|c|c|c|}
\hline \multirow{7}{*}{$\begin{array}{l}\text { Grupo } \\
1978\end{array}$} & & \\
\hline & Tradutor 1 & is based on sufficient attendance only. \\
\hline & Tradutor 2 & is based solely on attendance to classes. \\
\hline & Tradutor 3 & results solely from verification of attendance. \\
\hline & Tradutor 4 & (omitiu) \\
\hline & Tradutor 5 & will be graded only on the student's attendance. \\
\hline & Tradutor 6 & is a result of student's attendance. \\
\hline \multirow{6}{*}{$\begin{array}{l}\text { Grupo } \\
1998\end{array}$} & Tradutor 7 & relies only on the attendance. \\
\hline & Tradutor 8 & results from attendance verification only. \\
\hline & Tradutor 9 & (omitiu) \\
\hline & Tradutor 10 & is based only on minimum attendance requirements. \\
\hline & Tradutor 11 & is based only on attendance. \\
\hline & Tradutor 12 & (omitiu) \\
\hline
\end{tabular}

Nota: alto grau de dispersão

\begin{tabular}{lll} 
& \multicolumn{1}{c}{ 126 } & 2. Ensino Religioso \\
\hline & Tradutor 1 & 2. Religion \\
Grupo & Tradutor 2 & 2. Religion \\
1978 & Tradutor 3 & 2. Religion Instruction \\
& Tradutor 4 & (omitiu) \\
& Tradutor 5 & 2. Religious education \\
& Tradutor 6 & 2. Religious Education \\
\hline \multirow{3}{*}{ Grupo } & Tradutor 7 & 2. Religious Education \\
1998 & Tradutor 8 & 2. Religious Teaching \\
& Tradutor 9 & (omitiu) \\
& Tradutor 10 & 2. Religion \\
& Tradutor 11 & 2. Relig. Education \\
& Tradutor 12 & (omitiu)
\end{tabular}

Nota: item repetido (semelhante ao número 61). Tradutor 9 omitiu neste item, embora tenha traduzido no item 61.

\begin{tabular}{lll} 
& \multicolumn{1}{c}{ 127 - } & F = Freqüentou \\
\hline & Tradutor 1 & (omitiu) = Attended \\
Grupo & Tradutor 2 & (omitiu) \\
1978 & Tradutor 3 & F = attended \\
& Tradutor 4 & (omitiu) \\
& Tradutor 5 & F = Attended \\
& Tradutor 6 & F = Attended \\
\hline \multirow{4}{*}{ Grupo } & Tradutor 7 & F = Performed \\
1998 & Tradutor 8 & F: Attended \\
& Tradutor 9 & (omitiu) \\
& Tradutor 10 & F = Attended \\
& Tradutor 11 & F = attended \\
& Tradutor 12 & (omitiu)
\end{tabular}

Notas:

1-Sete ocorrências para Attended

2-Quatro omissões

3-Uma ocorrência para performed

$128-\quad N F=$ Não Freqüentou

\begin{tabular}{lll} 
& 128 - & NF $=$ Não Freqüentou \\
\hline & Tradutor 1 & (omitiu) = Not attended \\
Grupo & Tradutor 2 & NF = did not attend \\
1978 & Tradutor 3 & NF $=$ not attended \\
& Tradutor 4 & (omitiu) \\
& Tradutor 5 & NF $=$ Not Attended \\
& Tradutor 6 & NF $=$ Did not attend \\
\hline & Tradutor 7 & NF $=$ Not Performed \\
Grupo & Tradutor 8 & NF: Did not Attend \\
1998 & Tradutor 9 & NF - Not Attended \\
& Tradutor 10 & NF $=$ Not Attended \\
& Tradutor 11 & NF = not attended \\
& Tradutor 12 & (omitiu)
\end{tabular}

Notas:

1-Seis ocorrências para not attended 
2-Três ocorrências para did not attend

3-Duas omissões

4-Uma ocorrência para not performed

\begin{tabular}{|c|c|c|}
\hline $\begin{array}{l}\text { Grupo } \\
1978\end{array}$ & $\begin{array}{l}\text { Tradutor } 1 \\
\text { Tradutor } 2 \\
\text { Tradutor } 3 \\
\text { Tradutor } 4 \\
\text { Tradutor } 5 \\
\text { Tradutor } 6\end{array}$ & $\begin{array}{l}\text { (omitiu) } \\
\text { (omitiu) } \\
\text { THIS DOCUMENT CONTAINS NO AMENDMENTS OR ERASURES. } \\
\text { (omitiu) } \\
\text { THIS DOCUMENT DOES NOT CONTAIN AMENDMENTS OR ERASURES. } \\
\text { THIS DOCUMENT HAS NEITHER AMENDMENTS NOR ERASURES. }\end{array}$ \\
\hline $\begin{array}{l}\text { Grupo } \\
1998\end{array}$ & $\begin{array}{l}\text { Tradutor } 7 \\
\text { Tradutor } 8 \\
\text { Tradutor } 9 \\
\text { Tradutor } 10 \\
\text { Tradutor } 11 \\
\text { Tradutor } 12\end{array}$ & $\begin{array}{l}\text { This document does not bear any erasures or amendments } \\
\text { This document contains neither amendments nor erasures. } \\
\text { (omitiu) } \\
\text { THIS DOCUMENT HAS NO AMENDMENTS OR ERASURES } \\
\text { THIS DOCUMENT IS FREE OF ERASURES OR AMENDMENTS. } \\
\text { (omitiu) }\end{array}$ \\
\hline \multicolumn{3}{|c|}{$\begin{array}{l}\text { Notas: } \\
\text { 1-Cinco omissões } \\
\text { 2- Alto grau de dispersão }\end{array}$} \\
\hline & $130-$ & CN: $\quad F L S$ \\
\hline $\begin{array}{l}\text { Grupo } \\
1978\end{array}$ & $\begin{array}{l}\text { Tradutor } 1 \\
\text { Tradutor } 2 \\
\text { Tradutor } 3 \\
\text { Tradutor } 4 \\
\text { Tradutor } 5 \\
\text { Tradutor } 6\end{array}$ & $\begin{array}{l}\text { (omitiu) } \\
\text { (omitiu) } \\
\text { (omitiu) } \\
\text { (omitiu) } \\
\text { CN: } \\
\text { [N.T: No information on record on Certificate of Birth, Pages, Book, City and } \\
\text { State.] }\end{array}$ \\
\hline $\begin{array}{l}\text { Grupo } \\
1998\end{array}$ & $\begin{array}{l}\text { Tradutor } 7 \\
\text { Tradutor } 8 \\
\text { Tradutor } 9 \\
\text { Tradutor } 10 \\
\text { Tradutor } 11 \\
\text { Tradutor } 12\end{array}$ & $\begin{array}{l}\text { Birth Certificate: [-] Pages: [-] Book: }[-] \\
\text { (omitiu) } \\
\text { (omitiu) } \\
\text { (omitiu) } \\
\text { (omitiu) } \\
\text { (omitiu) }\end{array}$ \\
\hline
\end{tabular}

Nota: item em branco no original. A abreviatura NT nos parece inadequado para Translator's note.

\begin{tabular}{|c|c|c|}
\hline & $131-$ & MUNICÍPIO: \\
\hline \multirow{6}{*}{$\begin{array}{l}\text { Grupo } \\
1978\end{array}$} & Tradutor 1 & (omitiu) \\
\hline & Tradutor 2 & \multirow{5}{*}{$\begin{array}{l}\text { STATE: } \\
\text { on Certificate of Birth, Pages, Book, City and }\end{array}$} \\
\hline & Tradutor 3 & \\
\hline & Tradutor 4 & \\
\hline & Tradutor 5 & \\
\hline & Tradutor 6 & \\
\hline \multirow{5}{*}{$\begin{array}{l}\text { Grupo } \\
1998\end{array}$} & $\begin{array}{l}\text { Tradutor } 7 \\
\text { Tradutor } 8\end{array}$ & $\begin{array}{l}\text { City: }[-] \text { State: }[-] \\
\text { (omitiu) }\end{array}$ \\
\hline & Tradutor 9 & (omitiu) \\
\hline & Tradutor 10 & (omitiu) \\
\hline & Tradutor 11 & (omitiu) \\
\hline & Tradutor 12 & (omitiu) \\
\hline
\end{tabular}

Nota: item em branco no original

\begin{tabular}{lll} 
& 132 - & Menções - Conceitos \\
\hline & Tradutor 1 & Grades/Marks \\
Grupo & Tradutor 2 & Grading Scale \\
1978 & Tradutor 3 & GRADES/MARKS \\
& Tradutor 4 & (omitiu) \\
& Tradutor 5 & DESIGNATORS - GRADES \\
& Tradutor 6 & GRADES - CONCEPTS \\
\hline \multirow{3}{*}{ Grupo } & Tradutor 7 & Letter Grades \\
1998 & Tradutor 8 & MENTIONS - CONCEPTS \\
& Tradutor 9 & Concepts \\
& Tradutor 10 & GRADES \\
& Tradutor 11 & GRADES \\
& Tradutor 12 & MARKS - GRADES
\end{tabular}


Nota: alto grau de dispersão.

\begin{tabular}{lll} 
& \multicolumn{1}{c}{ 133 } & Excelente \\
\hline & Tradutor 1 & Excellent \\
Grupo & Tradutor 2 & Excellent \\
1978 & Tradutor 3 & Excellent \\
& Tradutor 4 & (omitiu) \\
& Tradutor 5 & Excellent \\
\hline & Tradutor 6 & Excellent \\
\hline \multirow{3}{*}{ Grupo } & Tradutor 7 & Excellent \\
1998 & Tradutor 8 & Excellent \\
& Tradutor 9 & Excellent \\
& Tradutor 10 & Excellent \\
& Tradutor 11 & Excelent
\end{tabular}

Nota: baixo grau de dispersão. Uma ocorrência de erro de grafia.

\begin{tabular}{lll} 
& \multicolumn{1}{c}{ 134 - } & Bom \\
\hline & Tradutor 1 & Good \\
Grupo & Tradutor 2 & Good \\
1978 & Tradutor 3 & Good \\
& Tradutor 4 & (omitiu) \\
& Tradutor 5 & Good \\
\hline & Tradutor 6 & Good \\
\hline \multirow{3}{*}{ Grupo } & Tradutor 7 & Good \\
1998 & Tradutor 8 & Good \\
& Tradutor 9 & Good \\
& Tradutor 10 & Good \\
& Tradutor 11 & Good
\end{tabular}

Nota: sem dispersão. Apenas um tradutor omitiu.

\begin{tabular}{lll} 
& \multicolumn{1}{c}{ 135 - } & Satisfatório \\
\hline & Tradutor 1 & Fair \\
Grupo & Tradutor 2 & Satisfactory \\
1978 & Tradutor 3 & Satisfactory \\
& Tradutor 4 & (omitiu) \\
& Tradutor 5 & Satisfactory \\
& Tradutor 6 & Satisfactory \\
\hline \multirow{3}{*}{ Grupo } & Tradutor 7 & Satisfactory \\
1998 & Tradutor 8 & Satisfactory \\
& Tradutor 9 & Satisfactory \\
& Tradutor 10 & Average \\
& Tradutor 11 & Satisfactory \\
& Tradutor 12 & Satisfactory
\end{tabular}

Notas:

1-Uma ocorrência para Fair

2-Nove ocorrências para Satisfactory

3-Uma omissão

4-Uma ocorrência para Average

\begin{tabular}{lll} 
& \multicolumn{1}{c}{ 136 - } & Sofrível \\
\hline & Tradutor 1 & Poor \\
Grupo & Tradutor 2 & Poor \\
1978 & Tradutor 3 & Poor \\
& Tradutor 4 & (omitiu) \\
& Tradutor 5 & Mediocre \\
\hline & Tradutor 6 & Poor \\
\hline \multirow{4}{*}{ Grupo } & Tradutor 7 & Needs improvement \\
1998 & Tradutor 8 & Poor \\
& Tradutor 9 & Poor \\
& Tradutor 10 & Poor \\
& Tradutor 11 & Inadequate \\
& Tradutor 12 & (omitiu)
\end{tabular}


Notas:

1-Sete ocorrências para Poor

2-Duas omissões

3-Uma ocorrência para Mediocre

4-Uma ocorrência para Needs Improvement

5-Uma ocorrência para Inadequate

\begin{tabular}{lll} 
& \multicolumn{1}{c}{137 - } & Insatisfatório \\
\hline & Tradutor 1 & Unsatisfactory \\
Grupo & Tradutor 2 & Unsatisfactory \\
1978 & Tradutor 3 & Unsatisfactory \\
& Tradutor 4 & (omitiu) \\
& Tradutor 5 & Unsatisfactory \\
& Tradutor 6 & Dissatisfactory \\
\hline \multirow{3}{*}{ Grupo } & Tradutor 7 & Unsatisfactory \\
1998 & Tradutor 8 & Unsatisfactory \\
& Tradutor 9 & Fail \\
& Tradutor 10 & Failed \\
& Tradutor 11 & Insatisfying \\
& Tradutor 12 & (omitiu)
\end{tabular}

Notas:

1-Seis ocorrências para Unsatisfactory

2-Duas omissões

3-Uma ocorrência para Dissatisfactory

4-Uma ocorrência para Fail

5-Uma ocorrência para Failed

6-Uma ocorrência para Insatisfying, termo que nos parece inadequado em sua grafia.

\begin{tabular}{lll} 
& \multicolumn{1}{c}{ 138 } & Certificado \\
\hline & Tradutor 1 & CERTIFICATE \\
Grupo & Tradutor 2 & CERTIFICATE \\
1978 & Tradutor 3 & CERTIFICATE \\
& Tradutor 4 & CERTIFICATE \\
& Tradutor 5 & CERTIFICATE \\
& Tradutor 6 & CERTIFICATE \\
\hline \multirow{4}{*}{ Grupo } & Tradutor 7 & Certificate \\
1998 & Tradutor 8 & CERTIFICATE \\
& Tradutor 9 & Certificate \\
& Tradutor 10 & CERTIFICATE \\
& Tradutor 11 & CERTIFICATE \\
& Tradutor 12 & CERTIFICATE
\end{tabular}

Nota: sem dispersão

139 - O Diretor da Escola Estadual "Maria Trujilo Torloni"

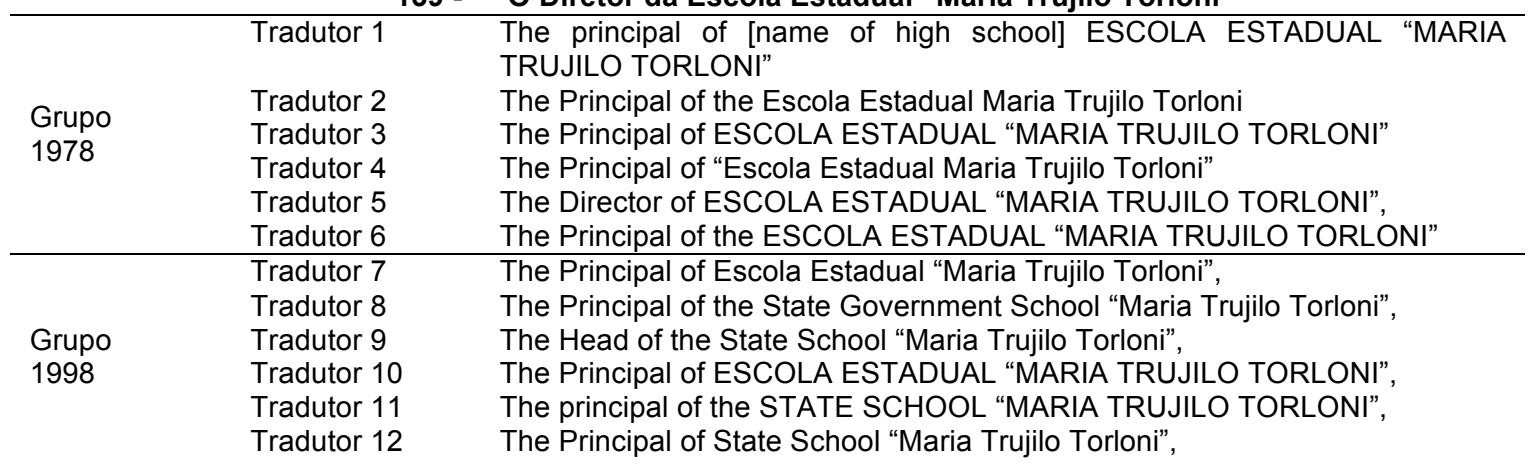

Notas:

1-Seis ocorrências para The Principal of

2-Quatro ocorrências para The Principal of the

3-Uma ocorrência para The Director of

4-Uma ocorrência para The Head of the

5-Dispersão para Escola Estadual "Maria Trujilo Torloni". Alguns tradutores traduziram "Escola Estadual". 
144 -

\begin{tabular}{lll} 
& 144 - & concluiu o/a \\
\hline & Tradutor 1 & completed the \\
Grupo & Tradutor 2 & $\begin{array}{l}\text { completed the } \\
\text { completed the }\end{array}$ \\
1978 & Tradutor 3 & concluded the \\
& Tradutor 4 & completed the \\
& Tradutor 5 & completed the \\
& Tradutor 6 & concluded the \\
Trupo & Tradutor 7 & completed the \\
1998 & Tradutor 8 & has completed the \\
& Tradutor 9 & completed the \\
& Tradutor 10 & completed the
\end{tabular}

Notas:

1-Oito ocorrências para completed the

2-Duas ocorrências para concluded the

3-Uma ocorrência para has fulfilled all the requirements for completion of the

4-Uma ocorrência para has completed the

\begin{tabular}{lll} 
& $145-$ & $3^{\text {a }}$ série do Ens. Médio \\
\hline & Tradutor 1 & third [last] year of secondary [high school] studies \\
Grupo & Tradutor 2 & $3^{\text {rd }}$ year of Secondary School \\
1978 & Tradutor 3 & $3^{\text {rd }}$ [i.e., last] Grade of Senior High School \\
& Tradutor 4 & $3^{\text {rd }}$ grade of Senior High School \\
& Tradutor 5 & $3^{\text {rd }}$ grade of High School Education \\
& Tradutor 6 & 3 rd Grade of the High School Education \\
\hline \multirow{4}{*}{ Grupo } & Tradutor 7 & $3^{\text {rd }}$ Grade of High School \\
1998 & Tradutor 8 & $3^{\text {rd }}$ grade of Secondary School \\
& Tradutor 9 & $3^{\text {rd }}$ grade of High School \\
& Tradutor 10 & $3^{\text {rd }}$ Grade of Secondary Education \\
& Tradutor 11 & $3^{\text {rd }}$ class of High School \\
& Tradutor 12 & $3^{\text {rd }}$ Grade of High School
\end{tabular}

Nota: dispersão entre os grupos. Grupo de 1998 apresentou menor dispersão.

146 - no ano letivo de 1998,

\begin{tabular}{|c|c|c|}
\hline $\begin{array}{l}\text { Grupo } \\
1978\end{array}$ & $\begin{array}{l}\text { Tradutor } 1 \\
\text { Tradutor } 2 \\
\text { Tradutor } 3 \\
\text { Tradutor } 4 \\
\text { Tradutor } 5 \\
\text { Tradutor } 6 \\
\end{array}$ & $\begin{array}{l}\text { in the school year of } 1998, \\
\text { in the school year of } 1998, \\
\text { in the academic year of } 1998, \\
\text { in } 1998 \text { school year } \\
\text { in the school year of } 1998, \\
\text { in the school year of } 1998,\end{array}$ \\
\hline $\begin{array}{l}\text { Grupo } \\
1998\end{array}$ & $\begin{array}{l}\text { Tradutor } 7 \\
\text { Tradutor } 8 \\
\text { Tradutor } 9 \\
\text { Tradutor } 10 \\
\text { Tradutor } 11 \\
\text { Tradutor } 12\end{array}$ & $\begin{array}{l}\text { in the school year of } 1998, \\
\text { in the school year of } 1998 \\
\text { in the school year of } 1998, \\
\text { in the school year } 1998, \\
\text { in the school year } 1998 \\
\text { in the school year of } 1998,\end{array}$ \\
\hline
\end{tabular}

Notas:

1-Oito ocorrências para in the school year of 1998

2-Uma ocorrência para in the academic year of 1998

3-Uma ocorrência para in 1998 school year

4-Duas ocorrências para in the school year 1998

\begin{tabular}{|c|c|c|}
\hline \multirow{6}{*}{$\begin{array}{l}\text { Grupo } \\
1978\end{array}$} & Tradutor 1 & and that she is thus entitled to further pursue studies at university level. \\
\hline & Tradutor 2 & being eligible to proceed with her studies at University level. \\
\hline & Tradutor 3 & and is accordingly qualified to proceed to Higher Education Level studies. \\
\hline & Tradutor 4 & being able to follow her studies at College Level. \\
\hline & Tradutor 5 & and is qualified to proceed to Higher Education. \\
\hline & Tradutor 6 & being entitled to continue on Higher Education \\
\hline \multirow{6}{*}{$\begin{array}{l}\text { Grupo } \\
1998\end{array}$} & Tradutor 7 & thus being entitled to further studies on Higher Education. \\
\hline & Tradutor 8 & therefore, she is able to continue the studies at the university level. \\
\hline & Tradutor 9 & and that she is able to proceed with her studies in a higher level. \\
\hline & Tradutor 10 & being able to continue her studies in higher education. \\
\hline & Tradutor 11 & and is entitled to carry on her studies at University level. \\
\hline & Tradutor 12 & being qualified to continue her studies at a university. \\
\hline
\end{tabular}


Nota: alto grau de dispersão

\begin{tabular}{|c|c|c|}
\hline \multicolumn{3}{|c|}{$148-\quad 22 / 04 / 99$} \\
\hline & Tradutor 1 & 22 April 1999 \\
\hline & Tradutor 2 & April 22, 1999 \\
\hline Grupo & Tradutor 3 & Apr/22/99 \\
\hline \multirow{5}{*}{1978} & Tradutor 4 & 04/22/1999 \\
\hline & Tradutor 5 & $04 / 22 / 99$ \\
\hline & Tradutor 6 & 04/22/99 \\
\hline & Tradutor 7 & $04 / 22 / 99$ \\
\hline & Tradutor 8 & 22/Apr/99 \\
\hline & Tradutor 9 & April, 22, 1999 \\
\hline \multirow[t]{3}{*}{1998} & Tradutor 10 & $04 / 22 / 1999$ \\
\hline & Tradutor 11 & April $22^{\text {nd }}, 1999$ \\
\hline & Tradutor 12 & $22 / 04 / 99$ \\
\hline
\end{tabular}

Nota: alto grau de dispersão

\begin{tabular}{|c|c|c|}
\hline & & Data \\
\hline & Tradutor 1 & Date \\
\hline & Tradutor 2 & Date \\
\hline Grupo & Tradutor 3 & Date \\
\hline 1978 & Tradutor 4 & Date \\
\hline & Tradutor 5 & Date \\
\hline & Tradutor 6 & Date \\
\hline & Tradutor 7 & Date \\
\hline & Tradutor 8 & Date \\
\hline Grupo & Tradutor 9 & (omitiu) \\
\hline 1998 & Tradutor 10 & Date \\
\hline & Tradutor 11 & DATE \\
\hline & Tradutor 12 & Date \\
\hline
\end{tabular}

Nota: sem dispersão. Uma omissão.

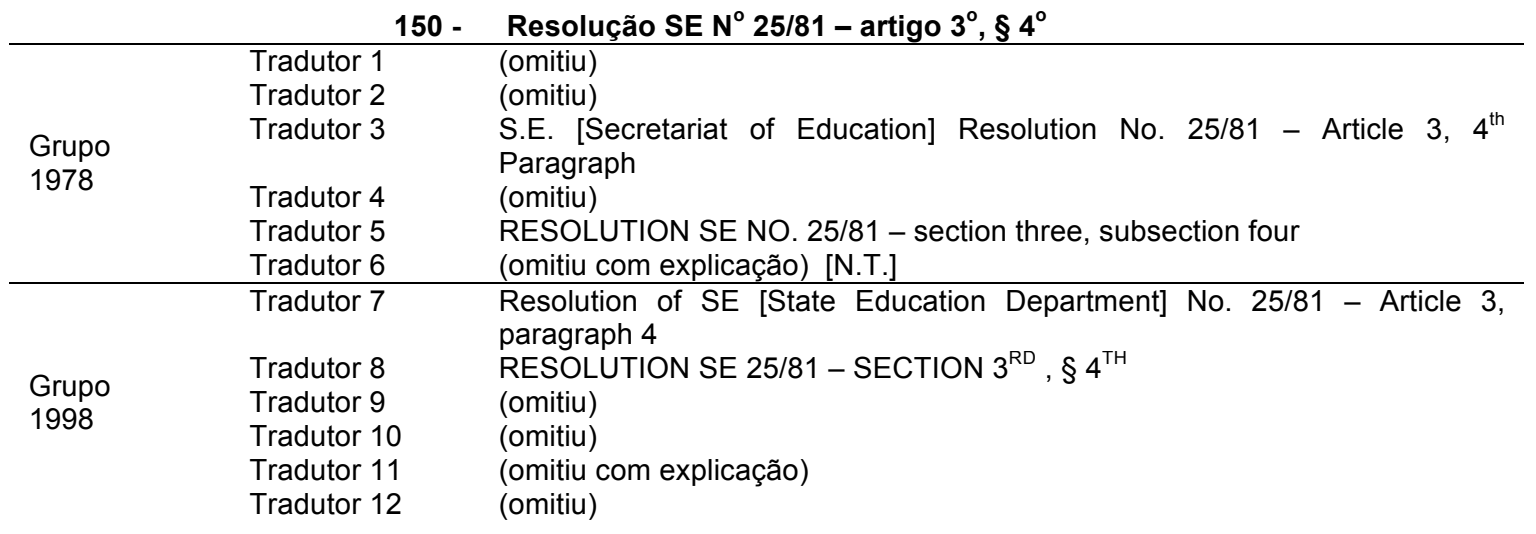

Nota: oito omissões. Apenas duas com explicação ou nota do tradutor.

A partir do item 151 até o final, a maioria dos tradutores omitiu esse trecho. No documento original os campos estão em branco.

\begin{tabular}{|c|c|c|}
\hline \multirow{6}{*}{$\begin{array}{l}\text { Grupo } \\
1978\end{array}$} & Tradutor 1 & School records in case of trancfer [hlank] \\
\hline & Tradutor 2 & (omitiu) \\
\hline & Tradutor 3 & For use by the recipient school \\
\hline & Tradutor 4 & (omitiu) \\
\hline & Tradutor 5 & For the use of the receiving school \\
\hline & Tradutor 6 & (omitiu com explicação) \\
\hline \multirow{6}{*}{$\begin{array}{l}\text { Grupo } \\
1998\end{array}$} & Tradutor 7 & This is for the receiving school use \\
\hline & Tradutor 8 & For use by the school that will admit the student \\
\hline & Tradutor 9 & (omitiu) \\
\hline & Tradutor 10 & (omitiu) \\
\hline & Tradutor 11 & (omitiu) \\
\hline & Tradutor 12 & (omitiu) \\
\hline
\end{tabular}


152 - em caso de matrícula no $2^{\circ}$ grau

\begin{tabular}{|c|c|c|}
\hline \multirow{6}{*}{$\begin{array}{l}\text { Grupo } \\
1978\end{array}$} & Tradutor 1 & (omitiu) \\
\hline & Tradutor 2 & (omitiu) \\
\hline & Tradutor 3 & in case of registration in Senior High School \\
\hline & Tradutor 4 & (omitiu) \\
\hline & Tradutor 5 & in case of enrollment in High School \\
\hline & Tradutor 6 & (omitiu com explicação) \\
\hline \multirow{7}{*}{$\begin{array}{l}\text { Grupo } \\
1998\end{array}$} & Tradutor 7 & in case of enrollment on High School \\
\hline & Tradutor 8 & in case of enrollment in Secondary School \\
\hline & Tradutor 9 & (omitiu) \\
\hline & Tradutor 10 & (omitiu) \\
\hline & Tradutor 11 & (omitiu) \\
\hline & Tradutor 12 & (omitiu) \\
\hline & $153-$ & ou no Ensino Superior \\
\hline \multirow{6}{*}{$\begin{array}{l}\text { Grupo } \\
1978\end{array}$} & Tradutor 1 & (omitiu) \\
\hline & Tradutor 2 & (omitiu) \\
\hline & Tradutor 3 & or Higher Education establisment \\
\hline & Tradutor 4 & (omitiu) \\
\hline & Tradutor 5 & or Higher Education \\
\hline & Tradutor 6 & (omitiu com explicação) \\
\hline \multirow{7}{*}{$\begin{array}{l}\text { Grupo } \\
1998\end{array}$} & Tradutor 7 & or Higher Education Institute \\
\hline & Tradutor 8 & or University (blank table) \\
\hline & Tradutor 9 & (omitiu) \\
\hline & Tradutor 10 & (omitiu) \\
\hline & Tradutor 11 & (omitiu) \\
\hline & Tradutor 12 & (omitiu) \\
\hline & $154-$ & DOE Suplemento \\
\hline \multirow{6}{*}{$\begin{array}{l}\text { Grupo } \\
1978\end{array}$} & Tradutor 1 & (omitiu) \\
\hline & Tradutor 2 & (omitiu) \\
\hline & Tradutor 3 & D.O.E. [State Official Gazette] Supplement \\
\hline & Tradutor 4 & (omitiu) \\
\hline & Tradutor 5 & State Official Gazette (DOE) Supplement \\
\hline & Tradutor 6 & (omitiu com explicação) \\
\hline \multirow{7}{*}{$\begin{array}{l}\text { Grupo } \\
1998\end{array}$} & Tradutor 7 & DOE [State Official Register] Addendum \\
\hline & Tradutor 8 & (omitiu com explicação) \\
\hline & Tradutor 9 & (omitiu) \\
\hline & Tradutor 10 & (omitiu) \\
\hline & Tradutor 11 & (omitiu) \\
\hline & Tradutor 12 & (omitiu) \\
\hline & $155-$ & $\mathbf{N}^{\circ}$ / Data / Caderno / Página \\
\hline \multirow{6}{*}{$\begin{array}{l}\text { Grupo } \\
1978\end{array}$} & Tradutor 1 & (omitiu) \\
\hline & Tradutor 2 & (omitiu) \\
\hline & Tradutor 3 & No. / Date / Section; Page \\
\hline & Tradutor 4 & (omitiu) \\
\hline & Tradutor 5 & NO. / DATE/ SECTION / PAGE \\
\hline & Tradutor 6 & (omitiu com explicação) \\
\hline \multirow{7}{*}{$\begin{array}{l}\text { Grupo } \\
1998\end{array}$} & Tradutor 7 & Number / Date / Book / Page \\
\hline & Tradutor 8 & (omitiu com explicação) \\
\hline & Tradutor 9 & (omitiu) \\
\hline & Tradutor 10 & (omitiu) \\
\hline & Tradutor 11 & (omitiu) \\
\hline & Tradutor 12 & (omitiu) \\
\hline & $156-$ & Observações \\
\hline \multirow{6}{*}{$\begin{array}{l}\text { Grupo } \\
1978\end{array}$} & Tradutor 1 & (omitiu) \\
\hline & Tradutor 2 & (omitiu) \\
\hline & Tradutor 3 & Notes \\
\hline & Tradutor 4 & (omitiu) \\
\hline & Tradutor 5 & NOTES \\
\hline & Tradutor 6 & (omitiu com explicação) \\
\hline \multirow{6}{*}{$\begin{array}{l}\text { Grupo } \\
1998\end{array}$} & Tradutor 7 & Notes \\
\hline & Tradutor 8 & (omitiu com explicação) \\
\hline & Tradutor 9 & (omitiu) \\
\hline & Tradutor 10 & (omitiu) \\
\hline & Tradutor 11 & (omitiu) \\
\hline & Tradutor 12 & (omitiu) \\
\hline
\end{tabular}


157 - Assinatura

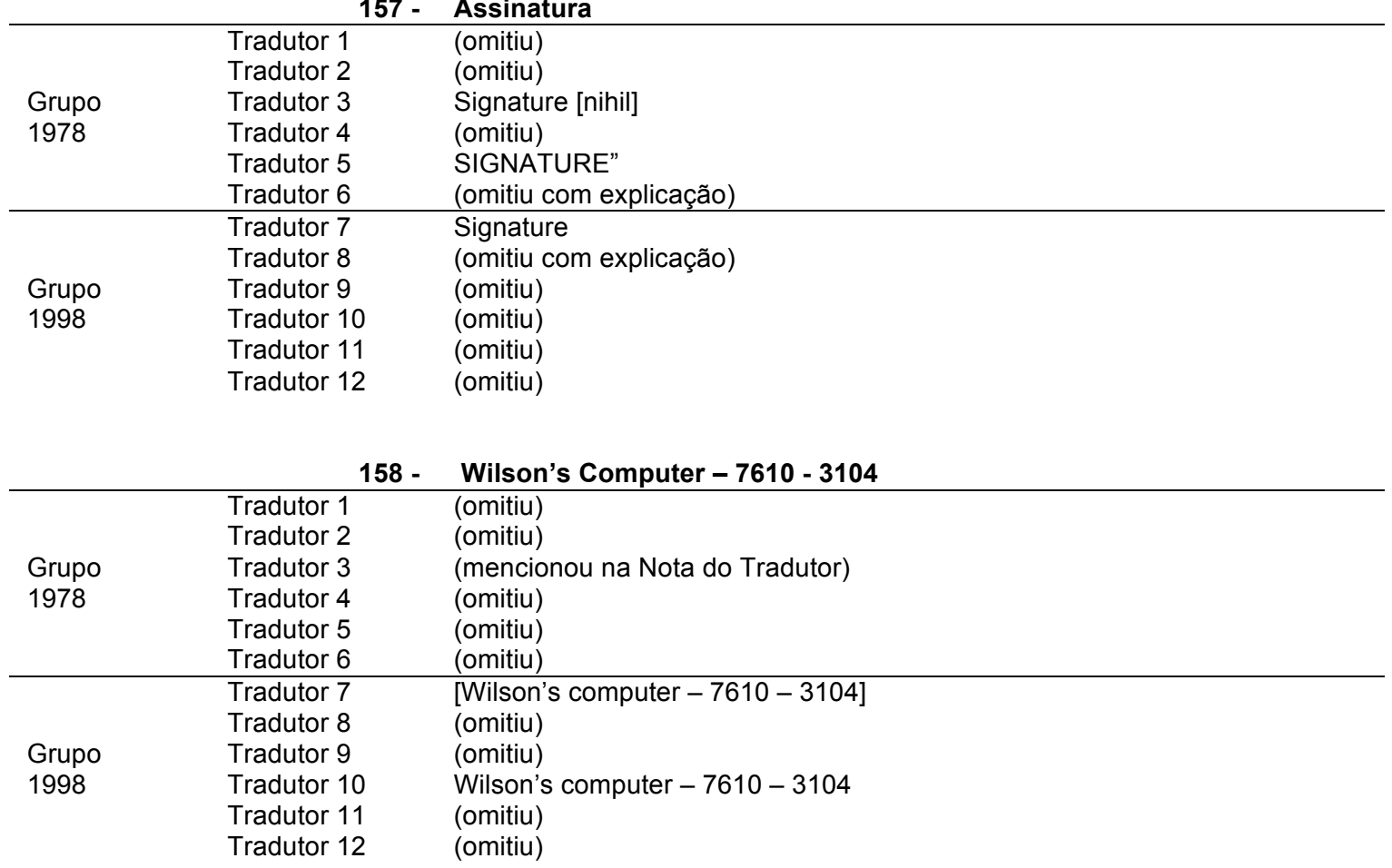

Nota: utilizamos a cor vermelha nas ocorrências de erro para facilitar a referência. 


\section{ELEMENTOS NÃO VERBAIS E HÍBRIDOS}

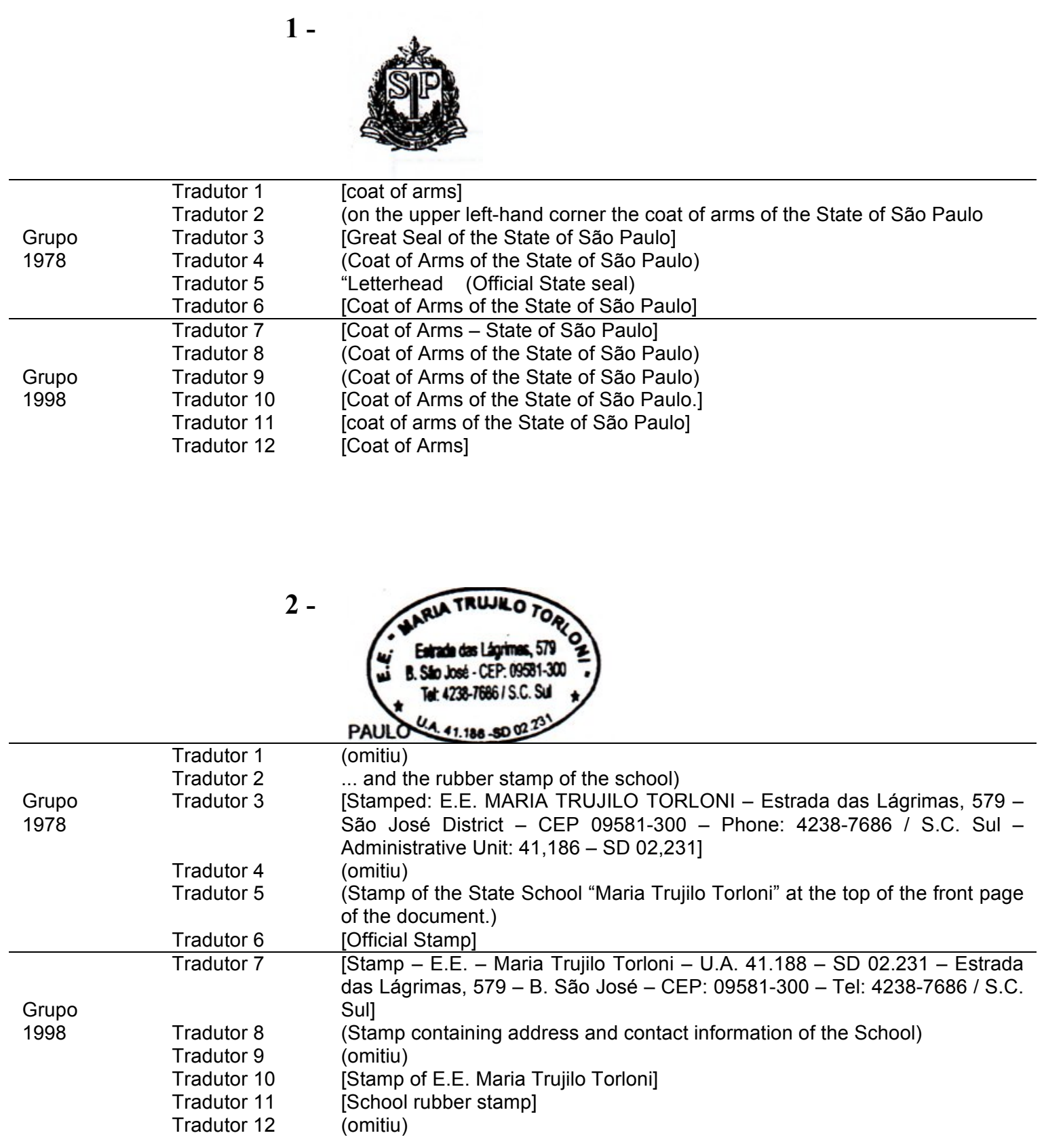




\section{LEGALIZAÇÕES NOTARIAIS E CARIMBOS COM RUBRICAS}

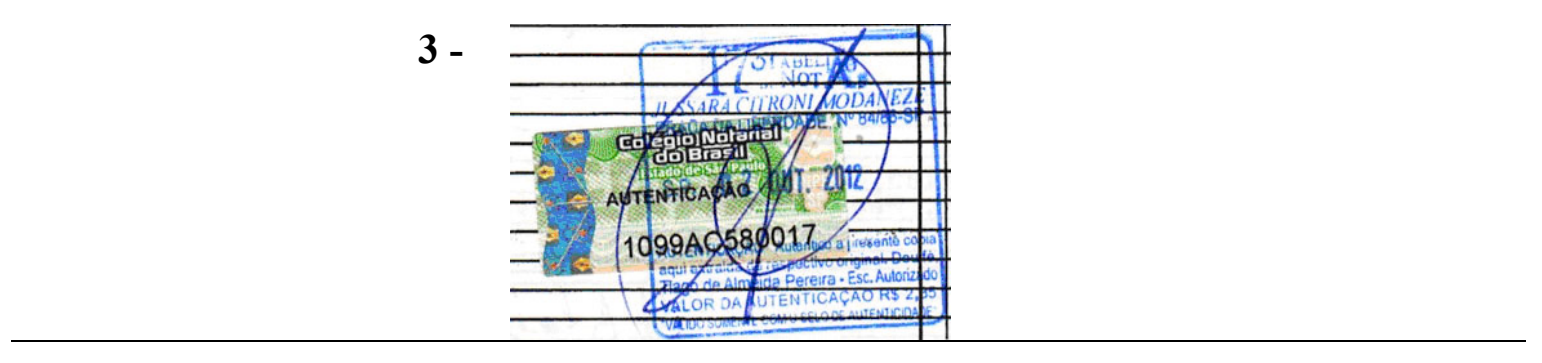

Tradutor 1

[Original document submitted for translation jointly with a copy certified on both pages as a true copy of the original by the Second General Registry of São Paulo (district of Liberdde), duly signed and dated 04 October 2012, with authenticity seals of the Notary Association of Brazil - São Paulo chambre]

Tradutor 2 Rubber stamp on face and reverse as follows:

Registrar of the Civil Registry of Natural Persons of the 2nd Subdistrict Liberdade - SP - Capital City

Grupo

1978

CERTIFIED COPY

I certify that this copy is in accordance with the original presented to me, to which I attest.

São Paulo, October 4, 2012.

(sgd) Veronica Silva Araujo do Rosário

Authorized Clerk

Each certified copy: $\mathrm{R} \$ 2,35$

$\begin{array}{ll}\text { Tradutor } 3 & \text { Valid only with the authenticity stamp } \\ \text { [On the face and reverse of the document translated above is the original }\end{array}$ stamp of notarization (authentication of the relevant copy) by the $3^{\text {rd }}\left(2^{\text {nd }}\right)$ Civil Register Officer, $3^{\text {rd }}\left(2^{\text {nd }}\right)$ Subdistrict of Liberdade, Capital City, initialled and dated October 04, 2012, accompanied by and adhesive holographic Authenticity Seal.].-

Tradutor $4 \quad$ (omitiu)

Tradutor 5 (Rubber stamp of the Civil Registrar of Natural Persons for the $2^{\text {nd }}$ Subdist. Liberdade, São Paulo, SP, dated 10/04/2012, on both pages of the document, attesting it to be a true copy of the original. Related initialed adhesive authenticity labels no. 1074AB459462 and 1074AB459461 of the Brazilian College of Notaries, SP.)"----

Tradutor 6 [There are Stamps of authentication of reprographic copy on the original document face and overleaf duly dated on October 22, 2012 and signed in the City of São Paulo and bearing seals of authentication under $n^{\circ}$ 1099AC580017 and 1099AC580016.]

$\begin{array}{ll} & \text { Tradutor } 7 \\ \text { Grupo } & \text { Tradutor } 8\end{array}$

(legalização diferente)

(legalização diferente) (There are two stamps legalizing the document as a 1998 true copy, set by the $17^{\text {th }}$ Notary Public's Office under the authenticity seals 1099AC580017 AND 1099AC580016.)

Tradutor 9

(Authentication stamp No. 1074AB459469)

(Copy certified true and correct on Oct 04, 2012, by Veronica Silva Araujo do Rosário, Authorized Clerk of the $2^{\text {nd }}$ Subdistrict - Liberdade Civil Registry Office.)

Tradutor 10 [Both faces of the document bears the stamp of the Registrar of Vital Statistics $-2^{\text {nd }}$ Subdistrict of Liberdade, SP - Capital, on October $4^{\text {th }}, 2012$, duly signed by Verônica Silva Araujo do Rosario, Authorized Clerk. There are also two authenticity seals numbers 1074AB459463 and 1074AB459464].

Tradutor 11 [rubber stamp: notarial authentication attesting this xerographic copy to be a true copy of the original document. Register Office Liberdade - São Paulo, on Oct. $4^{\text {th }} 2012$, over authentication sticker]

Tradutor 12 [The document bears two authentications duly signed and two authentication seals duly numbered.]

Nota: Alguns tradutores receberam uma cópia autenticada pelo $17^{\circ}$ Tabelião de Notas e outros pelo $2^{\circ}$ Subdistrito da Liberdade, o que explica a diferença nas traduções apresentadas. Anexamos apenas uma cópia do texto de partida autenticada pelo $17^{\circ}$ Tabelião de Notas. 


\section{4 - Este documento nilo conitum}

emendas nem rasuras.

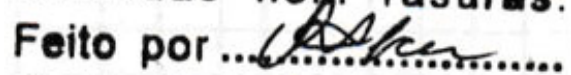

Conferido por

\begin{tabular}{|c|c|c|}
\hline \multirow{13}{*}{$\begin{array}{l}\text { Grupo } \\
1978\end{array}$} & Tradutor 1 & This document contains no erasures or amendments. Prepared by [initials] \\
\hline & Tradutor 2 & This document contains neither erasures nor amendments. \\
\hline & & Prepared by: (initial) \\
\hline & & Checked by: (blank) \\
\hline & Tradutor 3 & This document contains no amendments ore rasures. Done by: [initials] - \\
\hline & Tradutor 4 & Checked by: [nihil] \\
\hline & Tradutor 4 & (omitiu) \\
\hline & Tradutor 5 & This document does not contain amendments or erasures. \\
\hline & & Prepared by: (illegible signature) \\
\hline & & Checked by: (left blank) \\
\hline & Tradutor 6 & This document has neither amendments nor erasures. \\
\hline & & Prepared by: [illegible signature] \\
\hline & & Checked by: [no information on the record] \\
\hline \multirow{7}{*}{$\begin{array}{l}\text { Grupo } \\
1998\end{array}$} & Tradutor 7 & $\begin{array}{l}\text { [Stamp - This document does not bear any erasures or amendments - } \\
\text { Prepared by: [initials] - Conferred by: [- }] \text { - }\end{array}$ \\
\hline & Tradutor 8 & $\begin{array}{l}\text { (Stamp) This document contains neither amendments nor erasures. } \\
\text { Prepared by (illegible signature) }\end{array}$ \\
\hline & Tradutor 9 & This document does not contain any amendment and/or erasure. \\
\hline & Tradutor 10 & $\begin{array}{l}\text { [Stamp:] This document has no amendments or erasures. Prepared by (sgd.) } \\
\text { - Checked by [blank]. }\end{array}$ \\
\hline & Tradutor 11 & $\begin{array}{l}\text { [rubber stamp]: This document is free of erasures or amendments. } \\
\text { Made by [illegible signature] }\end{array}$ \\
\hline & & Conferred by \\
\hline & I radutor 12 & $\begin{array}{l}\text { Ihis document does not contain erasures or amendments. } \\
\text { Elaborated by: [initials]. }\end{array}$ \\
\hline
\end{tabular}




\section{ASSINATURAS}

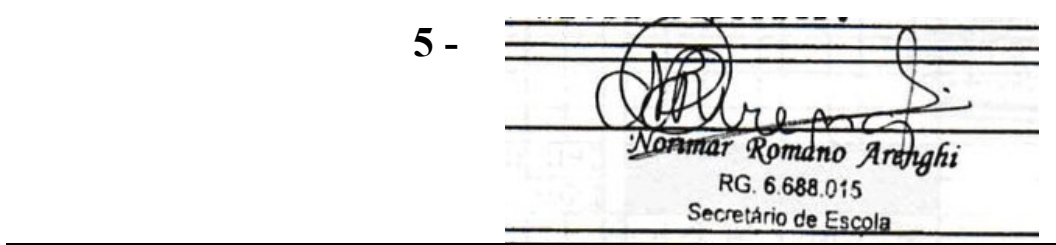

$\begin{array}{ll}\text { Grupo } & \text { Tradutor } 1 \\ 1978 & \text { Tradutor } 2 \\ & \text { Tradutor } 3 \\ & \text { Tradutor } 4\end{array}$

[signature] Registrar - Norimar Romano Arenghi - id. RG 6688015

(sgd) Norimar Romano Arenghi

School Registrar - Personal I.D. Card (RG) 6.688.015

[signed:] [i] Norimar Romano Arenghi, R.G. 6,688,015, School's Secretary,

Tradutor $4 \quad$ (sgd) illegible

Norimar Romano Arenghi

School Secretary

$\begin{array}{ll}\text { Tradutor } 5 & \text { (illegible signature) }\end{array}$

Norimar Romano Arenghi

R.G. 6.688 .015

School Secretary

Tradutor $6 \quad$ [illegible signature]

Norimar Romano Arenghi

Id Card RG: 6.688.015

School Secretary

Tradutor $7 \quad$ [Signature]

[Stamp - Norimar Romano Arenghi - Brazilian Official Identity Card No.

Grupo
1998

Tradutor 8

Tradutor 10

Tradutor 11

Tradutor 12
6.688.015 - School Secretary]

(illegible signature) Norimar Romano Arenghi - RG (Identity Card) 6.688.015 - School Secretary

(sgd.) Norimar Romano Arenghi, School Secretary (omitiu)

(sgd.)

Norimar Romano Arenghi

ID [RG]: 6.688.015

School Registrar

[signature illegible]

Norimar Romano Arenghi

ID 6.688.015

School secretary

Signed: [illegible signature]

Name: Norimar Romano Arenghi.

Title: School Secretary.

"RG": 6.688.015.

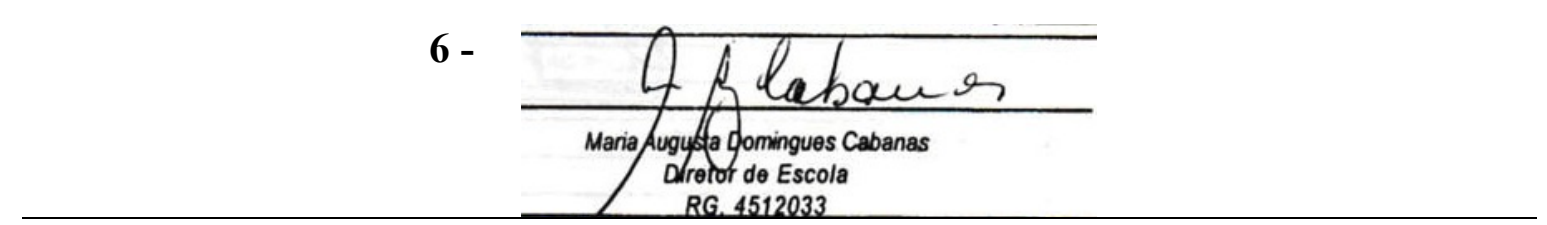

Tradutor 1

Grupo Tradutor 2

1978

Tradutor 3

[signature] Principal - Maria Augusta Domingues Cabanas - id. RG 4512033 (sgd) Maria Augusta Domingues Cabanas

School Principal - Personal I.D. Card (RG) 4512033

Tradutor $3 \quad$... [and iil

(sgd) illegible

Maria Augusta Domingues Cabanas

School Principal

RG 4512033

Tradutor $5 \quad$ (illegible signature)

Maria Augusta Domingues Cabanas

School Director

R.G. 4512033 
Tradutor $6 \quad$ [illegible signature]

Maria Augusta Domingues Cabanas

School Principal

Id Card RG: 4512033

[Signature]

Tradutor 7

[Stamp - Maria Augusta Domingues Cabanas - School Principal - Brazilian

Grupo

1998

Tradutor 8

Official Identity Card No. 4512033]

Tradutor 9

(illegible signature) Maria Augusta Domingues Cabanas - School Principal RG (Identity Card) 4512033

Tradutor 10

(sgd.) Maria Augusta Domingues Cabanas, Head of the School (omitiu)

(sgd.)

Maria Augusta Domingues Cabanas

School Principal

Tradutor 11

[signature illegible]

Maria Augusta Domingues Cabanas

PRINCIPAL

ID 4512033

Tradutor 12 Signed: [illegible signature].

Name: Maria Augusta Domingues Cabanas.

Title: School Principal.

"RG": 4512033.

\section{7 - Intróito do Tradutor}

Tradutor 1

I, [NAME], a certified public translator for Portuguese, English and French in São Paulo, Brazil, do hereby certify that this is a true and complete translation of a document in the PORTUGUESE language, entitled "Histórico Escolar $-2^{\circ}$ GRAU

Tradutor 2 I, the undersigned, Public and Sworn Translator, do hereby certify that on this date there was brought before me a document, in the Portuguese Language, describing - SCHOOL RECORDS - which I here translate into English as follows:

Tradutor 3 I, the undersigned, in my capacity as sworn translator in São Paulo, State of São Paulo, have duly translated into English the following document written in Portuguese (Histórico Escolar - $2^{\circ}$ Grau, EE "Maria Trujilo Torloni"- Vivian X. Orosco, 22-IV-99), which bears my seal and signature.-

Tradutor $4 \quad$ I, a Public Sworn Translator accredited by the Board of Commerce of the State of São Paulo, Federative Republic of Brazil, hereby certify and attest, for lawful purposes, that on this date, a document drawn up in Portuguese the original of a full curriculum - was presented to me for translation into English, and that I have made said translation as follows:

Tradutor 5 I, the undersigned, a Sworn Translator authorized by the laws of the Federative Republic of Brazil and, especially, by the Board of Commerce of the State of São Paulo, Brazil, to act within the said State, do hereby certify that on the date hereof an authenticated copy of a Transcript was presented to me for translation from Portuguese into English, and that I have made such translation as follows:

Tradutor 6 I, the undersigned Sworn Public Translator and Commercial Interpreter, hereby certify this is the faithful translation of an Academic Record Transcript - High School Education written in Portuguese, which I translate as follows:

I, [Name], undersigned Public Certified Translator duly admitted and sworn, do hereby certify that a document in Portuguese "Histórico Escolar" was presented to me and the true translation of which is set forth below:

Tradutor 8 I HEREBY CERTIFY that the text below is a translation of a document originally written in Portuguese and that, from now on, shall read as follows:

Tradutor 9 I, the undersigned, [Name], Certified Sworn Translator, do hereby certify this is a faithful translation of a document submitted to me in Portuguese.

Grupo Tradutor 10

1998

I, [Name], Official Translator and Interpreter, hereby certify that a document in the Portuguese language was submitted to me, which by virtue of my office, I translate into English as follows:

Tradutor 11 I, the undersigned Certified Translator for the English, German and Portuguese languages, certify and acknowledge the receipt of a document in Portuguese, which I identify as a certified copy of a School Record, which I translate into English, to the best of my knowledge and belief, as follows:

Tradutor 12 I, [NAME], a Sworn Translator and Commercial Interpreter for the English language, duly sworn by the Board of Trade of the State of São Paulo Federative Republic of Brazil, DO HEREBY CERTIFY that a document issued in the PORTUGUESE language was submitted to me, which I faithfully translated into ENGLISH, as follows: -.- 


\section{8 - Fecho do Tradutor}

\begin{tabular}{|c|c|c|}
\hline Grupo & Tradutor 1 & $\begin{array}{l}\text { NOTHING FURTHER. IN TESTIMONY WHEREOF I hereunto set my hand } \\
\text { and seal, at São Paulo, State of São Paulo, Brazil, this } 23^{\text {rd }} \text { day of July, } \\
2013 \text {. }\end{array}$ \\
\hline \multirow[t]{4}{*}{1978} & Tradutor 2 & $\begin{array}{l}\text { There was nothing further in the above document, which I am returning } \\
\text { together with this translation, which I have checked, acknowledge and sign } \\
\text { and to which I attest. São Paulo, July } 24,2013 \text {. }\end{array}$ \\
\hline & Tradutor 3 & $\begin{array}{l}\text { WITNESS MY HAND AND SEAL in São Paulo, SP, Federative Republic of } \\
\text { Brazil this fifth day of July, } 2013 \text { A.D. }\end{array}$ \\
\hline & Tradutor 5 & $\begin{array}{l}\text { NOTHING ELSE APPEARED IN THE AFORESAID DOCUMENT, which is } \\
\text { returned to the party interested together with this translation (consisting of } \\
\text { three printed pages, each printed on one side only) checked for accuracy, } \\
\text { found correct and signed by me. São Paulo, July } 01,2013 \text {. }\end{array}$ \\
\hline & Tradutor 6 & $\begin{array}{l}\text { Nothing else was contained in said original, which I return with this faithful } \\
\text { translation. In witness whereof, I have hereunto set my hand and seal of } \\
\text { office, in São Paulo, this June } 19,2013 \text {. }\end{array}$ \\
\hline \multirow[t]{4}{*}{1998} & Tradutor 8 & $\begin{array}{l}\text { I FINALLY CERTIFY that, to the best of my knowledge, the above translation } \\
\text { is true. In witness whereof, I have hereunto set my hand and seal. São } \\
\text { Paulo, June } 20^{\text {th }}, 2013 \text {. }\end{array}$ \\
\hline & Tradutor 9 & $\begin{array}{l}\text { Nothing else. Witness my hand and seal of office. São Paulo, Brazil, Jully 26, } \\
2013 .\end{array}$ \\
\hline & Tradutor 10 & $\begin{array}{l}\text { Nothing further. The foregoing is true, which I certify. São Paulo, July 16, } \\
2013 .\end{array}$ \\
\hline & Tradutor 11 & $\begin{array}{l}\text { NOTHING ELSE was written on the document above, which I return with this } \\
\text { translation typed in three pages, that I have checked, found in accordance } \\
\text { and hereby sign. São Paulo, July } 1^{\text {st }}, 2013 \text {. }\end{array}$ \\
\hline
\end{tabular}

\section{9 - Nota do Tradutor}

\begin{tabular}{|c|c|c|}
\hline & Tradutor 1 & --- \\
\hline & Tradutor 2 & Translator's Note: According to the Brazilian Education System, Secondary \\
\hline $\begin{array}{l}\text { Grupo } \\
1978\end{array}$ & Tradutor 3 & $\begin{array}{l}\text { School consists of } 3 \text { (three) years. } \\
\text { [Translator's Notes: }-1 \text {. The } 1^{\text {st }}, 2^{\text {nd }} \text {, and } 3^{\text {rd }} \text { Grades in Brazilian higher } \\
\text { secondary programs (segundo grau) are US complete Senior High School } \\
\text { equivalente. }-2 \text {. Other data and blanks are not applicable and / or filled in, } \\
\text { and, accordingly, have not been translated. }-3 \text {. In the lower left-hand corner } \\
\text { of the face and reverse: Wilson's Computer }-7610-3104] \text {.- }\end{array}$ \\
\hline
\end{tabular}

Tradutor 4

Tradutor 5

Tradutor 6

3 [N.T.]: 1- [N.T.: No information is provided on the record, about transfer in the respective school year]; 2 - [N.T: No information on record on Certificate of Birth, Pages, Book, City and State.]; 3 - [N.T: No information on the record in the box 90, 91, 92, 93 of the original Academic Record Transcript regarding Resolution SE $\mathrm{N}^{\circ} 25 / 81$ - article $3 \S 4$, to be provided by the receiving school in the High School Education or Higher Education]

\begin{tabular}{lll}
\hline & Tradutor 7 & \\
Trupo & Tradutor 8 & -- \\
1998 & Tradutor 9 & --
\end{tabular}


ANEXO A - Texto de partida

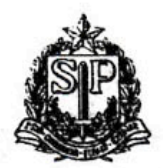

\section{GOVERNO DO ESTADO DE SĀO PAULO SECRETARIA DE ESTADO DA EDUCAÇĀO} SECRETARIA DE ESTADO DA EDUCAÇAO
COORDENADORIA DE ENSINO DA REGIAO METROPOLITANA DA GRANDE SĀO PAULOL
DELEGACIA DE ENSINO "PROF. CARLOS HUMBERTO VOLPOM" - (S.C.S)

ESCOLA ESTADUAL " MARIA TRUJILO TORLONI"

ENDEREÇO: Estrada das Lágrimas, 579 - Bairro Săo José - Cep. 09581-300 - São Caetano do Sul - São Paulo ATO DE CRIAÇĀO DA ESCOLA: Lei n 7986 , de 30/09/65

HISTÓRICO ESCOLAR - 2 GRAU

\begin{tabular}{|c|l|}
\hline 10 & $\begin{array}{l}\text { REGISTRO DE MATRICULA } \\
\text { (RM) DO ALUNO }\end{array}$ \\
\hline 19.608 \\
\hline
\end{tabular}

\begin{tabular}{|c|l|c|c|c|c|c|}
\hline 20 & \multicolumn{3}{|c|}{ DADOS DO ALUNO } \\
\hline Nome do aluno & VIVI AN XAV IER OROSCO Localicade & Estado & Nacionalidade & Dia & Més & Ano \\
\hline \multirow{2}{*}{ Nascimento } & São Paulo & SP & Brasil. & 24 & 10 & 81 \\
\cline { 2 - 7 } & &
\end{tabular}

Deixa de constar a filiaçăo do(a) aluno(a), conforme RES. SE-12, publicada em 13/06/95, que homologa a DELIBERAÇĀo CEE № 04/95.

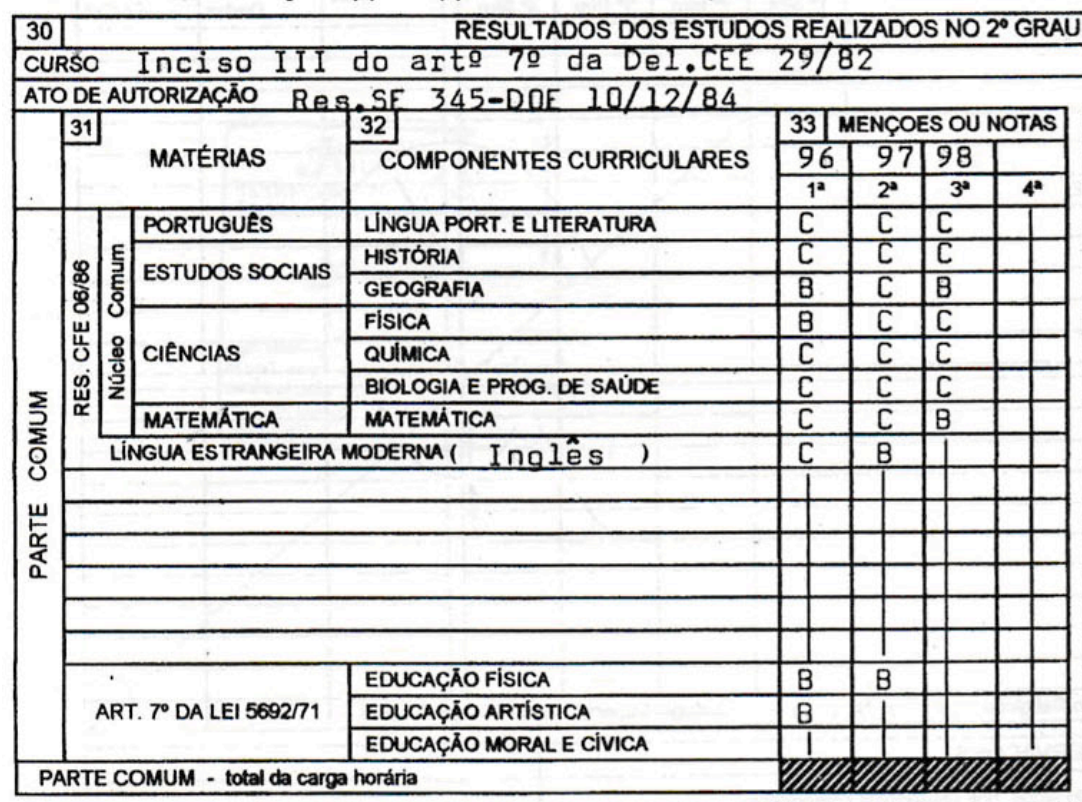
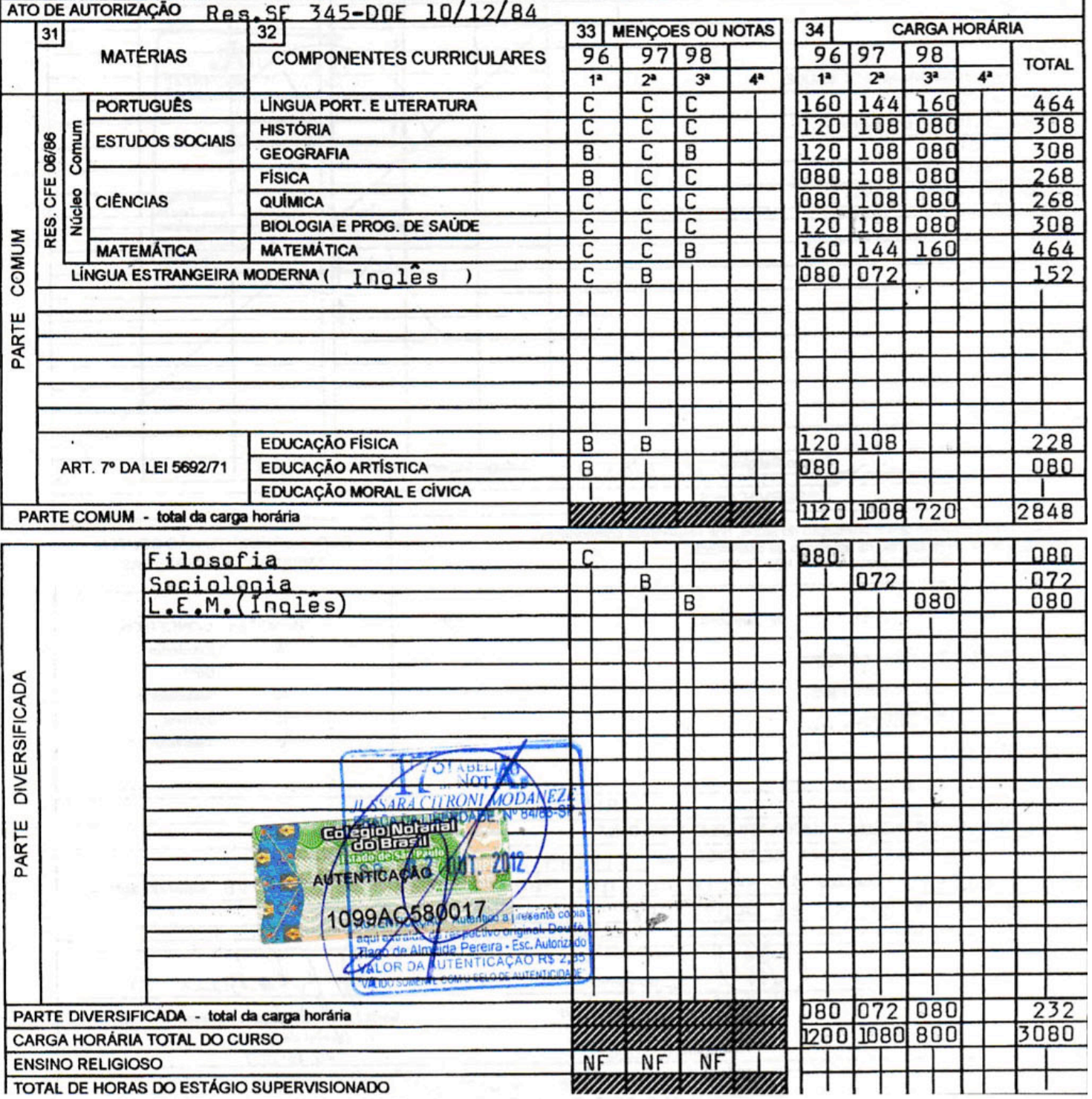
(verso)

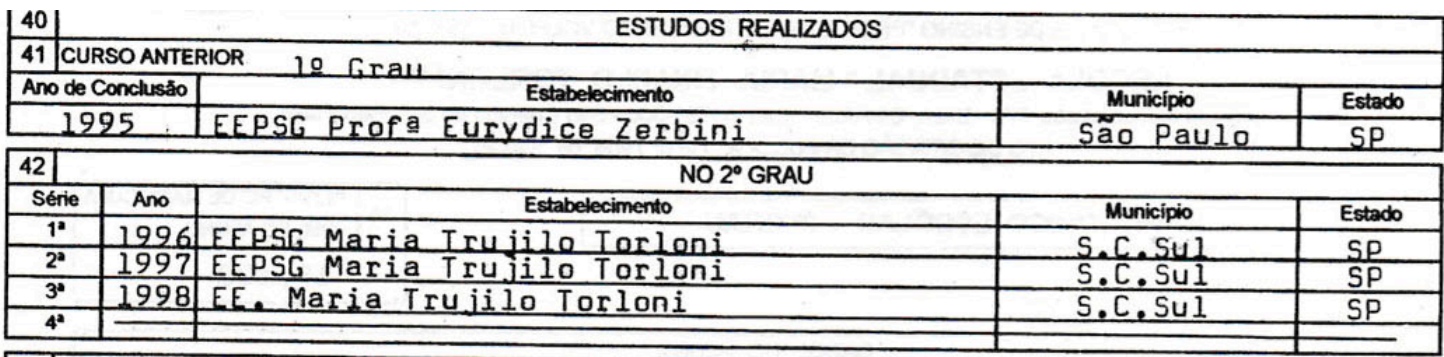

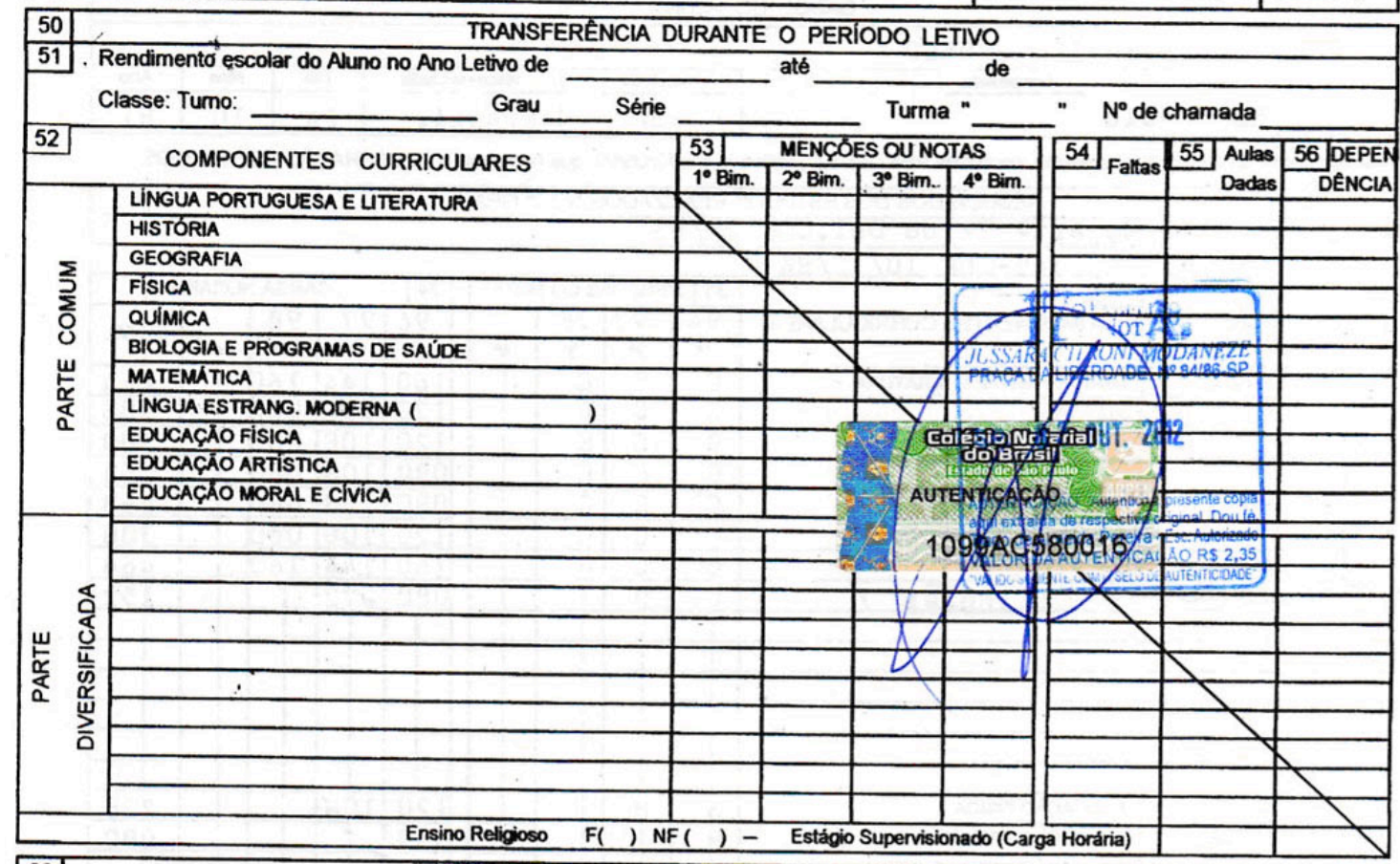

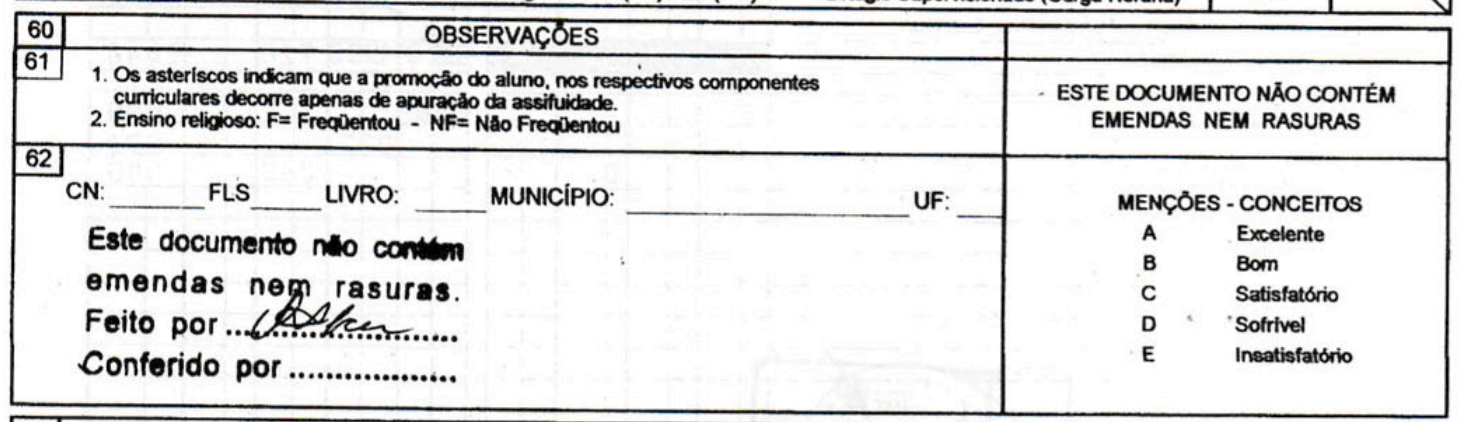

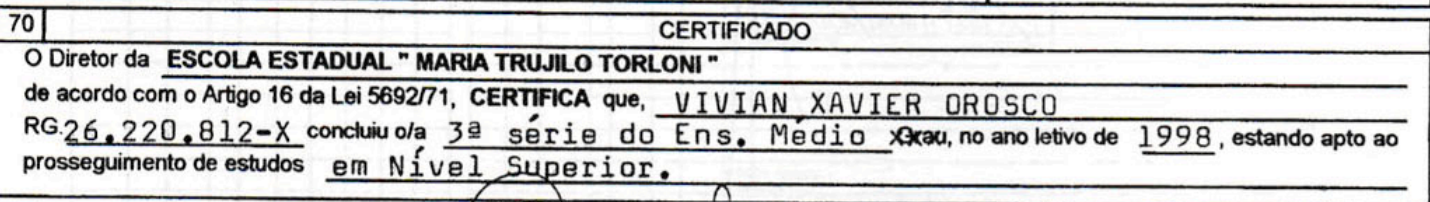

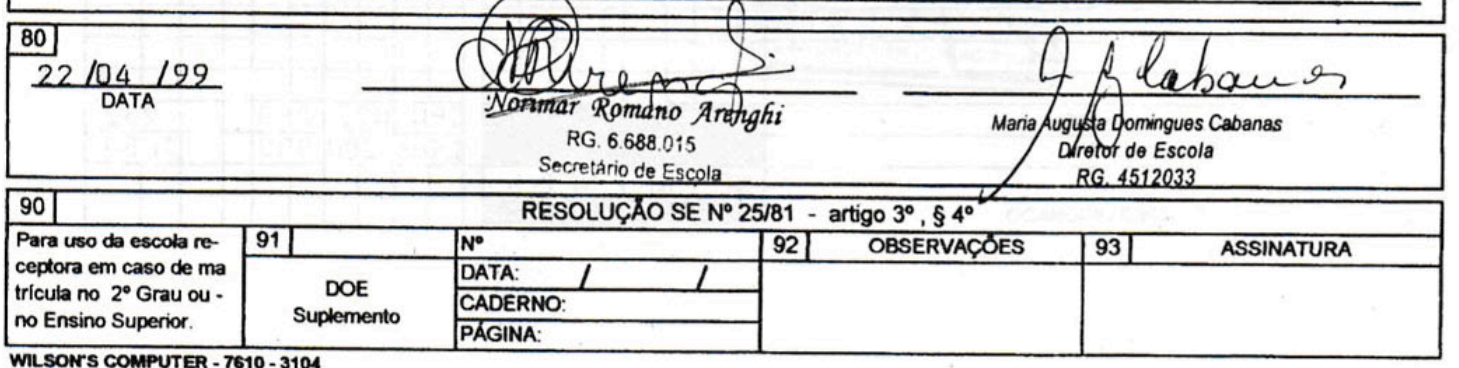




\section{ANEXO B - Junta Comercial do Estado de Minas Gerais - Anexo I da Resolução RP/07/2012 de 18 de outubro de 2012}

\section{ANEXO I \\ DA RESOLUÇÃO RP/07/2012 DE 18 DE OUTUBRO DE 2012}

Para efeito deste anexo, a sigla TPIC significa Tradutor Público Juramentado e Intérprete Comercial.

O TPIC deve empenhar-se ao máximo para que a tradução/ versão seja clara, objetiva, de fácil compreensão, não dando margem à ambiguidade. Deve ainda utilizar materiais e formas, tais como chancelas, selos, dentre outros, de forma a dificultar, ao máximo, a possibilidade de fraudes.

\section{1) APRESENTAÇÃO DA TRADUÇÃO JURAMENTADA.}

1.1) O trabalho deverá ser entregue em papel tamanho A4 $(21,0 \mathrm{~cm} \times 29,7 \mathrm{~cm})$, em formato retrato, com margens direita e esquerda de $3 \mathrm{~cm}$ e superior e inferior de $2,5 \mathrm{~cm}$.

1.2) O cabeçalho do documento deverá conter no mínimo: nome completo do TPIC, a expressão Tradutor Público Juramentado e Intérprete Comercial, o número e data da matrícula na JUCEMG, $n^{\circ}$ do CPF, o endereço completo (logradouro, cidade, CEP, telefone, e-mail e website, se houver) e indicação dos idiomas para os quais está habilitado.

1.3) O cabeçalho não é passível de contagem para efeito de cobrança de taxas ou emolumentos.

1.4) A apresentação gráfica da tradução, tanto quanto possível, deve ser semelhante à do texto ou documento original.

1.5) Caso necessário, alguns elementos do texto deverão ser citados em forma de Nota do Tradutor. Exemplo: à direita em cima, ou na margem inferior à esquerda, consta um símbolo representando as armas da república, o logotipo da empresa, etc.

1.6) Se a tradução contiver diversas páginas, essas deverão ser numeradas de forma contínua e unidas de forma tal que a união não possa ser desfeita sem deixar marcas visíveis. Pode-se carimbar as folhas grampeadas de tal maneira que o texto do carimbo fique alinhado apenas se as páginas estiverem juntas. Alternativamente o TPIC poderá fixar todas as páginas com selo tipo consular.

1.7) Os campos ou espaços não preenchidos, deverão ser assinalados com a expressão "em branco".

1.8) Caso a linha não seja completamente preenchida, o seu final deverá ser assinalado por meio de duas barras $(/ /)$.

\section{2) REGISTRO DA TRADUÇÃO}


A primeira linha antes do Termo de Abertura e a primeira linha das demais folhas da tradução/versão deverá conter o número da tradução, o número do livro e número da página, onde ficou registrada a tradução/versão.

\section{3) TERMO DE ABERTURA/ENCERRAMENTO DE UMA TRADUÇÃO/VERSÃO PÚBLICA}

3.1) O Termo de Abertura deverá conter o seguinte texto no idioma contratado:

Eu, $<$ nome do TPIC $>$, Tradutor Público Juramentado e Intérprete Comercial, certifico que me foi apresentado um documento <indicar o tipo de documento $>$ no idioma $<$ indicar o idioma $>$ para ser $<$ traduzido/vertido $>$ para o idioma $<$ indicar o idioma $>$, o que cumpri em razão do meu ofício, na forma abaixo:

3.2) Se uma cópia de tradução juramentada for solicitada em data posterior, faz-se a abertura com o seguinte texto no idioma contratado:

Revendo o Livro de Registro de Traduções número < indicar o ${ }^{0}$ do livro $>$ - página $<$ indicar o intervalo de páginas>, sob o número <número da tradução>, encontrei a seguinte tradução: <colocar o texto integral da tradução $>$ desde o Termo de Abertura até o Termo de Encerramento incluindo a data original da tradução. No fechamento da transcrição deverá constar: $<$ O referido é verdade e dou fé.

$<$ cidade do tradutor $>$, $<$ data de emissão da cópia $>$, $<$ nome do TPIC $>$, $<$ número de matrícula do TPIC $>$.

3.3) O Termo de Encerramento deverá conter o seguinte texto no idioma contratado:

Nada mais continha o documento que fielmente <traduzi/verti>, conferi, achei conforme e dou fé. Esta <tradução/versão> não implica julgamento sobre a forma, a autenticidade e/ou o conteúdo do documento. Local, data, nome completo do TPIC assinatura, número da matrícula TPIC.

Valor dos emolumentos cobrados (parágrafo único do artigo 35 do Decreto Federal 13.609 de 1943).

\section{4) TIPOS DE DOCUMENTOS}

4.1) No Termo de Abertura deverá ser identificado o tipo de documento, que poderá ser:

a) ORIGINAL - quando o documento apresentar assinatura, carimbo, chancela, ou outro elemento que o caracterize indiscutivelmente como original.

b) FOTOCÓPIA SIMPLES - quando o documento não apresentar autenticação.

c) FOTOCÓPIA AUTENTICADA - quando o documento apresentar autenticação oriunda de cartório ou repartição pública governamental, ou por pessoa que possua direito legal para tanto no país de emissão.

d) FAX - com a transcrição dos respectivos dados do remetente. 
e) ORIGEM ELETRÔNICA - documento extraído de arquivo eletrônico, em diferentes formatos tais como: jpg, pdf, xls, ptt, doc, docx, e-mail, nota fiscal eletrônica, página da internet, e outros formatos eletrônicos. No caso de e-mail ou páginas da internet, deverão ser citados dados de identificação pertinentes ao endereço de origem, data e hora em que foi baixado o arquivo, quando possível.

4.2) Nas hipóteses das letras “d” e "e", o TPIC deverá imprimir o documento e carimbá-lo no verso com o carimbo pessoal do TPIC e anotar os dados da tradução juramentada $\left(\mathrm{n}^{\mathrm{o}}\right.$ da tradução, número do livro e número da folha).

\section{5) INTEGRIDADE E EXATIDÃO}

5.1) A tradução deve ser a mais fiel possível ao texto original, tanto no conteúdo quanto na forma. Deve ser conservada a integridade do documento e mantido o sentido declaratório original.

5.2) Na ocorrência de texto repetido na tradução/versão, deve-se traduzir apenas uma vez e mencionar a repetição. Exemplo: Verso de documentos contendo legendas. Traduz-se a página uma vez e menciona na tradução juramentada que todas as demais páginas contêm aquele mesmo texto no verso.

5.3) Em geral, lista de departamentos de órgãos emissores do documento não são traduzidos. Não são traduzidas menções editoriais, nem referências bibliográficas (salvo se o usuário solicitar que sejam traduzidos os nomes das obras, o que deve ser feito em Nota do Tradutor. O usuário deverá informar ao TPIC a forma de tradução dos títulos das obras, segundo o critério da entidade para a qual a tradução é dirigida). Não são traduzidas informações sobre técnica de impressão. Exemplo: Modelo DOC 060684 impresso pela gráfica Xxx.

5.4) Sempre que possível em caso de múltiplos documentos, observar a sequencia cronológica dos mesmos.

5.5) O usuário pode requerer a tradução parcial de documento ou texto. Nesta hipótese deve ser mencionado claramente, logo no início da tradução, que se trata de tradução parcial de documento ou texto e informar as partes não traduzidas. Exemplo: a pedido da parte interessada, o contrato, que contém vinte cláusulas, teve apenas a cláusula quinta traduzida .

5.6) Quando se tratar de documento para instruir ação judicial, o usuário pode contratar a tradução parcial do documento. Entretanto, o usuário deve ser alertado sobre decisão do STJ (Resp. $n^{\text {o } 1227053), ~ q u e ~ a s s i m ~ d e c i d i u: ~}$

"1. Segundo o princípio da indivisibilidade do documento, este deve ser interpretado como um todo, não podendo ser fracionado para que se aproveite a parcela que interessa à parte, desprezando-se o restante. 2. Ineficácia probante da tradução parcial de contrato celebrado em idioma estrangeiro.

3. Inviabilidade de se dispensar a tradução na hipótese em que o documento estrangeiro apresenta-se como fato constitutivo do direito do autor." 
5.7) Os documentos encadernados ou integrantes de processos devem ser identificados como tal e descritos de forma sucinta. Exemplo: número do processo, vara em que tramita, total de páginas do processo e número das páginas em idioma estrangeiro que foram traduzidas.

5.8) No caso de documentos ou textos existentes em Carta Rogatória, o TPIC deverá traduzir apenas as páginas determinadas pelo juiz.

5.9) Em situações de texto com duplo sentido, deve-se fazer uma anotação/observação, esclarecendo as possibilidades de interpretação.

5.10) Na tradução juramentada a partir de tradução juramentada - (exemplo: um TPIC traduz documento original em alemão para o inglês e outro TPIC traduz a tradução do inglês para o português) - deve-se traduzir na íntegra a primeira tradução (em inglês) desde o introito ou Termo de Abertura até o fechamento ou Termo de Encerramento do primeiro tradutor.

\section{6) SINGULARIDADES}

6.1) Se o texto original apresentar singularidades como: rasuras, correções manuscritas, riscos que anulam palavras, estilo fora do comum, erros graves de ortografia, inscrições em outro idioma para o qual o TPIC não tem habilitação, deverá ser elaborada Nota do Tradutor, onde o TPIC relatará estas singularidades.

6.2) Quando existirem textos riscados, porém legíveis, deverão ser traduzidos, citando-se na tradução < palavra ou frase riscada $>$. Quando ilegíveis, deverá ser citado na tradução < palavra ou frase riscada e ilegível $>$.

6.3) Quando existirem textos riscados não traduzidos, o fato deve ser mencionado na Nota do Tradutor.

6.4) No caso de carimbos ou pequenos trechos em outro idioma, deve-se colocar uma Nota do Tradutor, informando que foram ignoradas as expressões escritas em outro idioma para o qual o TPIC não está habilitado. Exemplo: Na Bélgica a expressão "Carteira de Motorista" é escrita em 20 idiomas diferentes.

6.5) Notas explicativas ou informações prestadas pelo TPIC necessárias ao entendimento do órgão receptor da tradução deverão ser precedidas da observação 'Notas do Tradutor' ao longo do trabalho de tradução.

6.6) É dever de o TPIC informar previamente ao usuário que o texto inserido no documento em idioma para o qual ele não está habilitado não estará sendo traduzido, e que deverá ser traduzido por outro TPIC habilitado para o idioma em questão.

\section{7) DESIGNAÇÃo DE AUTORIDAdES, ARMAS, CARIMBOS, SELOS E ASSINATURAS}

7.1) As designações de autoridades públicas deverão ser citadas em sua forma original quando não houver equivalente traduzível. Não existindo equivalente traduzível, deverá ser explicado em Nota do Tradutor. 
7.2) As armas, os brasões, os selos-taxa, os lacres, os sinetes, as chancelas, os logotipos e similares, deverão ser mencionados e explicados, não necessariamente traduzidos ou detalhadamente descritos. O selo de fiscalização emitido pelo Poder Judiciário deve ser mencionado juntamente com seu respectivo número.

7.3) Os carimbos deverão ser localizados, mencionados e traduzidos. Se o mesmo carimbo aparecer mais de uma vez, o fato deve ser mencionado, acrescentando que são do mesmo teor.

7.4) As assinaturas e rubricas deverão ser mencionadas como estão. Se legível ou com indicação de quem firmou o documento, mencionar o nome de quem assinou ou rubricou. Se ilegível mencionar "assinatura ilegível”.

7.5) Todos os carimbos, selos e números de série, etc. deverão constar da tradução. O TPIC deverá identifica-lo usando colchetes [carimbo/selo, etc.] descrevendo suas características (posição, cor, formato). O conteúdo de carimbos e selos deverá ser traduzido. Se ilegível, informar $<$ texto ilegível $>$.

7.6) A legalização consular, assim como todos os selos, carimbos etc. deverá constar no corpo da tradução/versão. Exemplo: Em anexo/apenso ao documento se encontra a respectiva legalização feita pelo Consulado $<$ nome completo do consulado $>$ em $<$ cidade / país $>$ assinado por $<$ nome e cargo $>$ e datado de $<$ dia/mês/ano por extenso $>$, e selo de autenticação $\mathrm{n}^{\circ}$ $<\mathrm{xxxx}>$. Os dois documentos estão presos pelo selo $<$ cor / característica do selo $>$ oficial do referido consulado, $<$ se for o caso $>$.

\section{8) ENDEREÇOS}

8.1) Os endereços não deverão ser traduzidos, sendo transliterados ou transcritos, precedidos da palavra "endereço" ou seu equivalente no idioma estrangeiro.

\section{9) NÚMEROS E DATAS}

9.1) Os números serão repetidos sem alteração, algarismos romanos ou arábicos.

9.2) As datas, independente do formato no idioma estrangeiro, deverão ser traduzidas para o formato brasileiro, isto é dia, mês (por extenso) e ano. No caso de versão, a data deverá ser grafada no formato do idioma para o qual está sendo vertido o documento, escrevendo o mês por extenso.

9.3) Ao traduzir números do inglês para o português ou verter do português para o inglês, deverá ser feita a troca de vírgula por ponto e de ponto por vírgula.

9.4) Dados numéricos citados por extenso no original, também terão que ser repetidos por extenso na tradução/versão.

\section{0) ABREVIAÇÕES}


10.1) As abreviaturas, sempre que possível, deverão ser decodificadas e traduzidas. Entretanto sua forma original deve constar da tradução. Exemplo: CPF (Cadastro de Pessoa Física).

10.2) Nem sempre há necessidade de manter a forma original. Exemplo: Lic. Alberto Ferreira, traduzir, Dr. Alberto Ferreira, ou Ing. Ricardo Matos, traduzir Eng. Ricardo Matos.

\section{1) ERROS DE ORTOGRAFIA E GRAMÁTICA}

11.1) Os erros grosseiros do texto original devem ser mantidos na tradução/versão, assinalados por "sic". Em Nota do Tradutor deve-se chamar a atenção para o fato e ser apresentada a tradução mais próxima da palavra ou expressão.

\section{2) HISTÓRICOS ESCOLARES E DIPLOMAS}

12.1) Históricos escolares e diplomas deverão ser traduzidos com a máxima fidelidade ao original: tipo de escola, notas e denominação profissional ou grau acadêmico.

12.2) É vedado ao TPIC fazer equivalência de títulos, diplomas e tipos de escola.

\section{3) NOMES PRÓPRIOS E DE LUGARES}

13.1) Nomes próprios e de lugares, via de regra não devem ser traduzidos e sim repetidos como na escrita original com todos os sinais diacríticos (letras e acentos). Em Nota do Tradutor podese traduzir para o vernáculo nome de lugares em que exista correspondente comumente usado (Köln => Colônia, cidade alemã; Stockholm => Estocolmo, cidade Sueca, etc.)

13.2) Se o nome de lugar ou denominação geográfica houver sofrido alguma modificação, e isto for do conhecimento do TPIC, o fato deverá ser citado em Nota do Tradutor. Exemplo: Antigamente, Tchecoslováquia, agora República Tcheca.

13.3) Se a língua estrangeira usar um alfabeto diferente do latim, os nomes próprios terão que ser transliterados (isto é, copiado fielmente letra por letra)

13.4) Se a língua estrangeira não permitir a transliteração (árabe, por exemplo), o nome terá que ser transferido conforme as regras fonéticas da língua para a qual se está traduzindo.

\section{4) LIVRO DE REGISTRO DE TRADUÇÕES}

14.1) o Livro de Registro de Traduções deverá conter no máximo 400 (quatrocentas) folhas. A primeira página é utilizada para o Termo de Abertura e a última será utilizada para o Termo de Encerramento. A penúltima pagina será utilizada para Termos de Ocorrência.

14.2) TERMO DE ABERTURA, deverá conter o seguinte texto:

Este livro de número $<\mathrm{xxx}>$ contém $<\mathrm{xxx}>$ folhas numeradas sequencialmente de $01 \mathrm{a}$ $<\mathrm{xxx}>$ e servirá de Registro de Traduções Públicas do idioma $<$ indicar o idioma $>$ do 
Tradutor Público e Intérprete Comercial $<$ nome do TPIC $>$ matriculado na Junta Comercial do Estado de Minas Gerais, sob o número $<\mathrm{xxx}>$ em $<$ data da matrícula $>$, $\mathrm{CPF}$ número $<\mathrm{xxx}>$ com endereço na $<$ indicar o endereço completo $>$.

Cidade do $<$ TPIC $>$ e $<$ data do Termo de Abertura $<$ mesma data da primeira tradução $>$. Carimbo e assinatura $<$ do TPIC $>$.

14.3) TERMO DE ENCERRAMENTO, deverá conter o seguinte texto:

Este livro de número $<\mathrm{xxx}>$ contém $<\mathrm{xxx}>$ folhas numeradas sequencialmente de $01 \mathrm{a}$ $<\mathrm{xxx}>$ e serviu de Registro de Traduções Públicas do idioma <indicar o idioma $>$, referente ao período de $<$ citar as datas da $1^{\text {a }}$ e da última tradução $>$ do Tradutor Público e Intérprete Comercial $<$ nome do TPIC $>$, matriculado na Junta Comercial do Estado de Minas Gerais sob o número $<\mathrm{xxx}>$ em $<$ data da matrícula $>$, CPF número $<\mathrm{xxx}>$, com escritório à $<$ colocar o endereço completo $>$ Cidade do $<$ TPIC $>$ e $<$ data do Termo de Encerramento - data da última tradução $>$ Carimbo e assinatura $<$ do TPIC $>$.

14.4) TERMO DE OCORRÊNCIA, deverá relatar erros de numeração de pagina, repetição de número de tradução. Não é necessário fazer um Termo de Ocorrência para cada erro. Basta fazer um só, relatando todas as ocorrências, e numerando-as sequencialmente.

14.5) O número da página do Livro de Registro de Traduções não pode ser diferente do número da página lançado na Tradução Juramentada. Se na Tradução for lançada a página com numeração posterior a que caberia no Livro, deve-se deixar em branco os espaços entre a página onde deveria ser lançada a Tradução e a página onde será lançada a Tradução. Exemplo: a tradução que deveria ser lançada na página 20 foi registrada na tradução como de página 30. Desta forma, entre a página 20 até a página 29 , as páginas neste intervalo deverão receber lançamento em todas as folhas da expressão $<$ folha em branco $>$.

14.6) Se na Tradução Juramentada for lançada a página ou numeração da Tradução anterior a que deveria estar registrada no Livro de Registro de Traduções, deve-se registrar detalhadamente o fato no Termo de Ocorrência, de tal forma que sempre que o TPIC seja compelido a extrair certidão de inteiro teor da tradução ele possa localizar corretamente em que página do livro está transcrita a Tradução Juramentada.

\section{5) CONSULARIZAÇÃO DE DOCUMENTOS}

15.1) Para efeito de validade jurídica no Brasil, é obrigatória a consularização, legalização ou autenticação consular de documentos estrangeiros no país de sua emissão antes de sua tradução. O TPIC, depois de informar ao usuário do serviço sobre a invalidade jurídica de documento não consularizado, poderá traduzir o documento sem a consularização, legalização ou autenticação consular. Nesta hipótese, o fato deverá constar em Nota do Tradutor.

\section{6) DOCUMENTOS EM LÍNGUA PORTUGUESA}

16.1) Documentos oriundos de outros países de língua portuguesa não precisam ser traduzidos, visto que a língua oficial dos países lusófonos é a mesma, mas devem ser autenticadas pelos consulados ou embaixadas brasileiras nos respectivos países de emissão dos documentos. 


\section{ANEXO II \\ DA RESOLUÇÃO RP/07/2012 DE 18 DE OUTUBRO DE 2012}

(nova redação do art. $3^{\circ}$ da Resolução No RP/09/2011, de 2 de dezembro de 2011).

\begin{tabular}{|l|l|l|}
\hline Emolumentos & Horário de expediente & Fora do horário de expediente \\
\hline NORMAL & $\mathrm{N}=$ até quatro laudas/dia & //////// \\
\hline $\begin{array}{l}\text { URGENTE } \\
\text { Adicional de 50\% }\end{array}$ & $\mathrm{N}=$ mais de quatro laudas/dia & $/ / / / / / /$ \\
\hline $\begin{array}{l}\text { EXTRAORDINÁRIO } \\
\text { Adicional de 100\% }\end{array}$ & \multicolumn{1}{|c|}{$/ / / / / / /$} & $\begin{array}{l}\text { Qualquer número de laudas após as } \\
18 \text { (dezoito) horas nos dias úteis e nos } \\
\text { sábados, domingos e feriados. }\end{array}$ \\
\hline
\end{tabular}

OBSERVAÇÃO: "N" corresponde ao número de laudas traduzidas e disponibilizadas para entrega dentro do prazo acordado entre as partes. 